\title{
Environmental Management Performance Report November 2000
}

Prepared for the U.S. Department of Energy Assistant Secretary for Environmental Management

Project Hanford Managenent Contractor for the

U.S. Department of Energy under Contract DE-ACO6-90RL13200

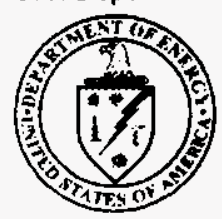
United States
Department of Energy P.O. Box 550 Richland, Washington 99352 
LERAL DISCLAMER

This report wes prepered es an eccount of work sponsored by an agency of the United States Government. Nefther the

Uniked States Government nor any agency thereof, nor any of their employecs, nor any of their contractore, subcontrectors or their employeces, makes any warranty, expreces or implied, or sasumes any logal liability or respondibility for the sccuracy. completeneas, or any third partys use or the resulte of such uae of any information, apparatus, product, or process

diecloeed, of represents that its ues would not infinge privately owned rights. Reference hereh to any specific commercial product, procees, or eervice by trade name, trademark, manuifecturer, or otherwiee, does not necesearily conattute or imply its endoreement, recommendetion, or fovoring by the United States Government or any soency thereof or the contractors or subcontractors. The viewe and opinions of suthors expreased hereln do not necesearity etate or reflect those of the United Stetes Government or any arency thereof.

This report has been reproduced from the beet avallable copy. 
DOE/RL-99-83

Revision 10

\section{Environmental Management Performance Report November 2000}

Date Published

November 2000

Prepared for the U.S. Department of Energy

Assistant Secretary for Environmental Management

Project Hanford Management Contractor for the

U.S. Department of Energy under Contract DE-AC06-96RL13200

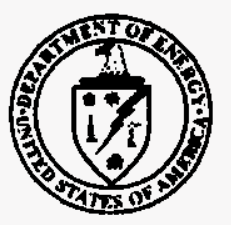

United States

Department of Energy

P.O. Box 550

Richland, Washington 99352

$\frac{\text { Chise grellexighand }}{\text { Release Approval }} \frac{11-8-00}{\text { Date }}$ 


\section{INTRODUCTION}

$\mathrm{T}$ he purpose of the Environmental Management Performance Report (EMPR) is to provide the Department of Energy Richland Operations Office's (DOE-RL's) report of Hanford's Environmental Management (EM) performance by:

- Project Hanford Management Contract (PHMC) through Fluor Hanford, Inc. (FH) and its subcontractors,

- Environmental Restoration Contract through Bechtel Hanford, Inc. (BHI), and its subcontractors,

- Pacific Northwest National Laboratories (PNNL) for Science and Technology support to the EM Mission, and

- Office of Safety Regulation of the TWRS Privatization Contractor.

This report is a monthly publication that summarizes EM Site performance under RL Operations Office. It is organized by the four sections listed above, with each section containing an Executive Summary and Area Performance Summaries. A glossary of terms is provided at the end of this report for reference purposes.

The report date on the cover reflects the month in which the report is released. 


\section{Project Hanford Management Contractor Environmental Management Performance Report to DOE Richland Operations Office November 2000}

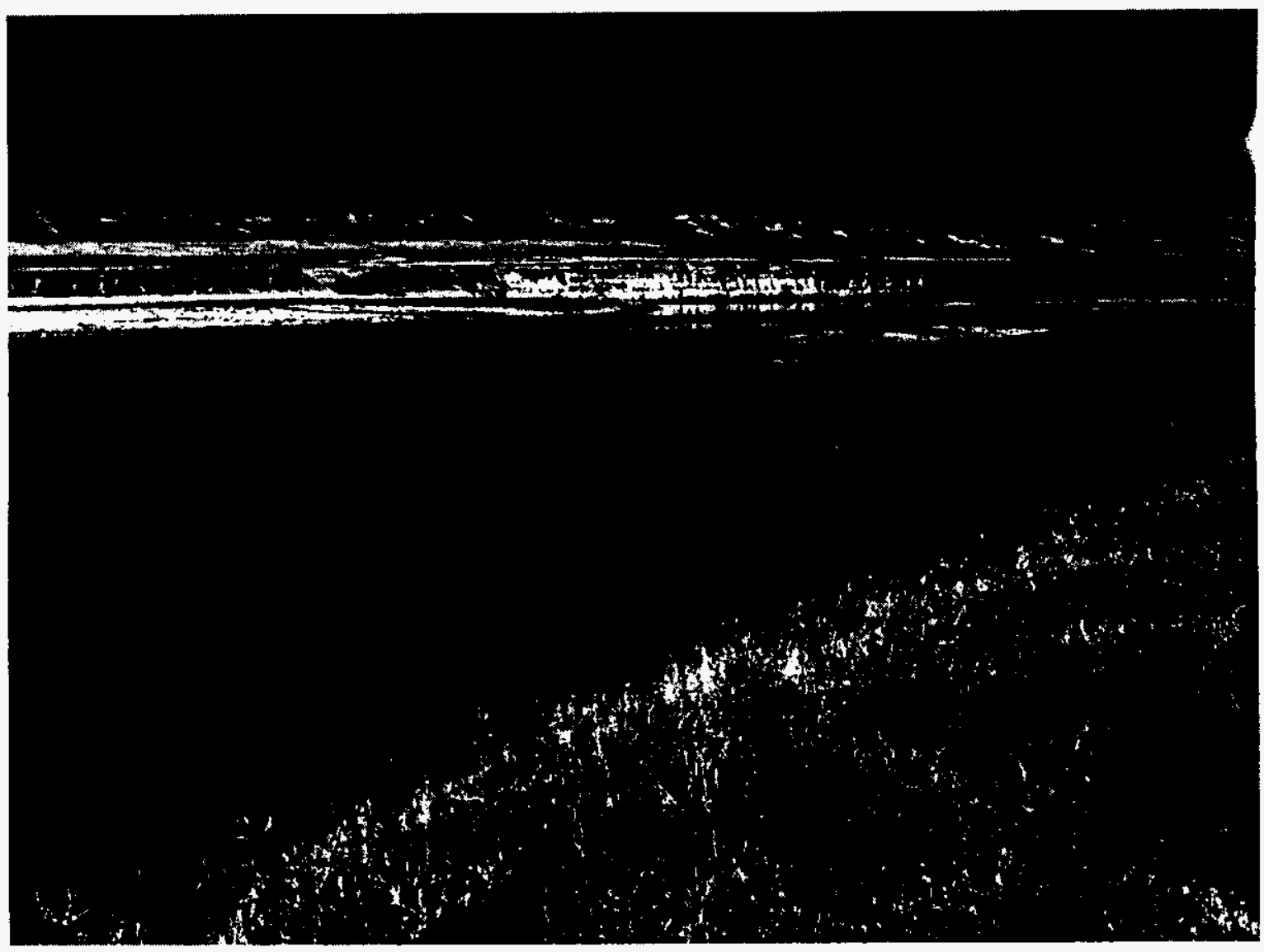

Fluor Hanford

A Fluor Global Services Company 


\section{Table of Contents}

Section

Executive Summary

The Plateau

Waste Management

Analytical Services (222-S, HASP, WSCF) B: 2

Nuclear Material Stabilization. $C: 1$

\section{The River}

River Corridor C: 2

Spent Nuclear Fuel.

Advanced Reactors Transition E

EM - 50 Science \& Technology Activities $\mathbf{F}$

\section{The Future}

HAMMER $\mathbf{G}$

\section{Multiple Outcomes}

Landlord. H

Support I

National Programs. 


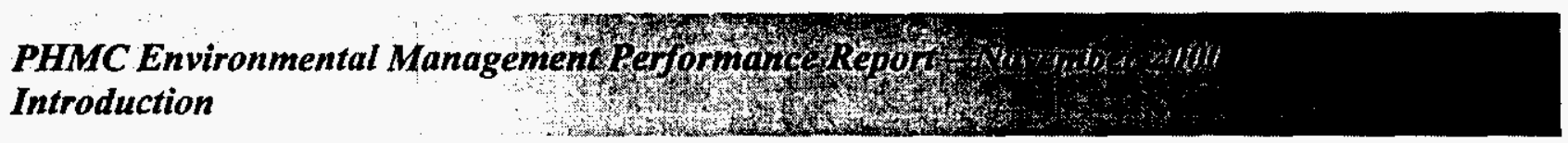

\section{INTRODUCTION}

The purpose of this report is to provide the Department of Energy Richland Operations Office (DOE-RL) a monthly summary of the Project Hanford Management Contractor's (PHMC) Environmental Management (EM) performance by Fluor Hanford (FH) and its subcontractors. In addition to project-specific information, it includes some PHMC-level data not detailed elsewhere in the report.

Section A, Executive Summary, provides an executive level summary of the cost, schedule, and technical performance described in this report. It summarizes performance for the period covered, highlights areas worthy of management attention, and provides a forward look to some of the upcoming key performance activities as extracted from the PHMC baseline.

The remaining sections provide detailed performance data relative to each individual Project (e.g., Waste Management, Spent Nuclear Fuels, etc.), in support of Section A of the report. Unless otherwise noted, the Safety, Conduct of Operations, and Cost/Schedule data contained herein is as of September 30, 2000. All other information is updated as of October 19, unless otherwise noted. A summary of the year's accomplishments has been included, grouped by the following categories:

- Momentum - How in terms of waste processing rates, etc. the cleanup of Hanford has been "sped up".

- Progress - What "things" have been achieved this year in terms of amounts and percentages.

- Completion \& Removal - What's done and what's gone.

"Stoplight" boxes are used to indicate at a glance the condition of a particular area. Green boxes denote on schedule. Yellows denote behind schedule but recoverable. Red is either missed or unrecoverable. 


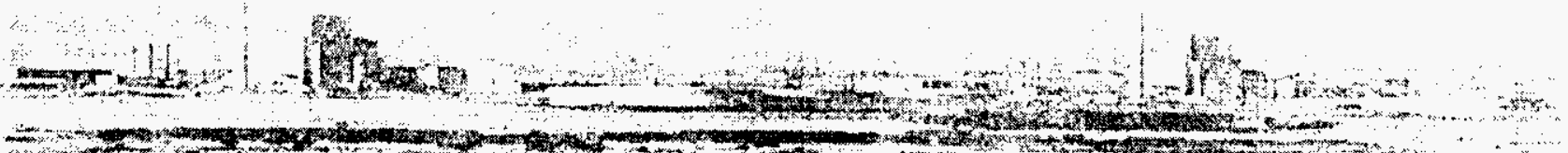

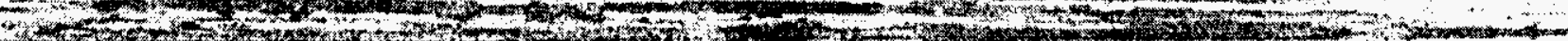

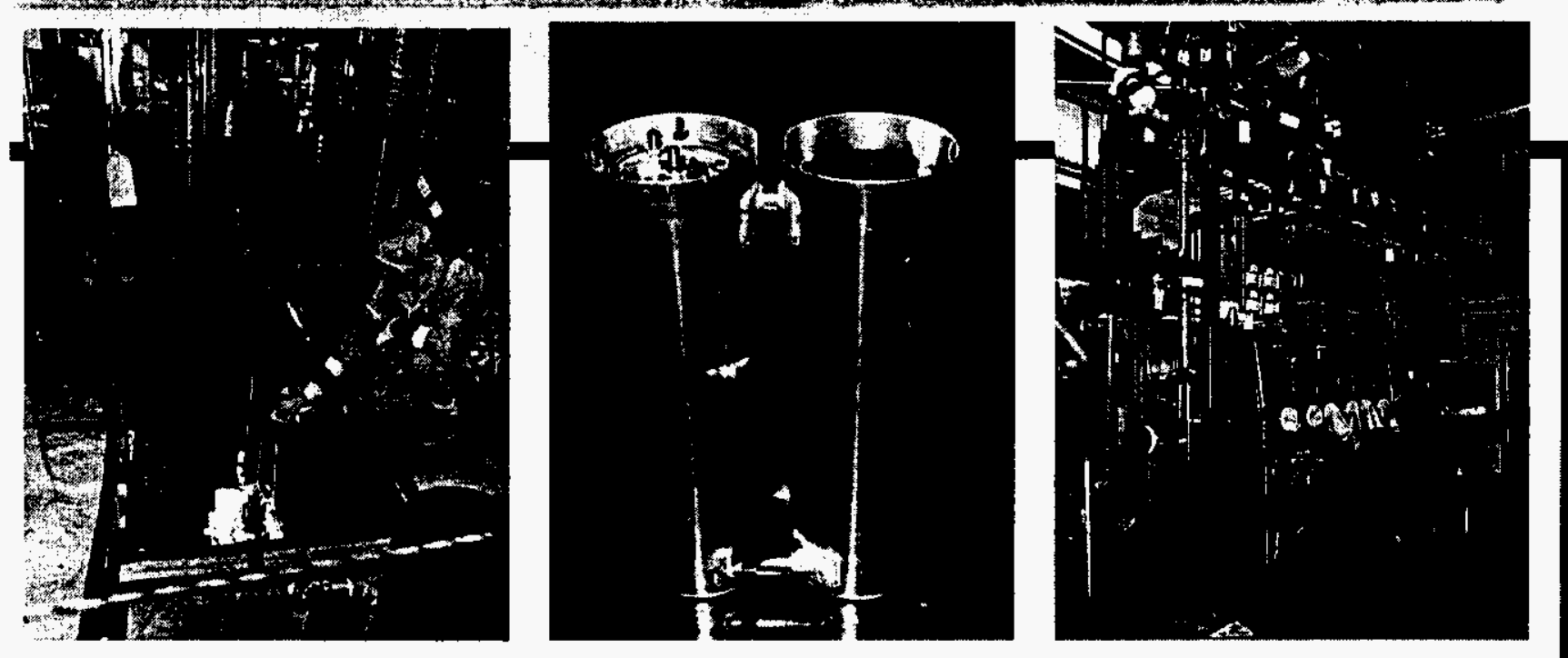

\section{Section A} Executive Summary 


\section{INTRODUCTION}

This section provides an executive level summary of the performance information covered in this report and is intended to bring to Management's attention that information considered to be most noteworthy. All cost, schedule, milestone commitments, performance measures, and safety data is current as of September 30. Accomplishments, Issues and Integration items are current as of October 19 unless otherwise noted.

The section begins with a summary of notable accomplishments for FY 2000, which are considered to have made the greatest contribution toward safe, timely, and cost-effective, clean up. In addition, notable accomplishments for the first three weeks of FY 2001 are also included. Following the accomplishment section is an overall fiscal year-to-date summary analysis addressing cost, schedule, and milestone performance. Overviews of safety ensue. The next segment of the Executive Summary, entitled Critical Issues, is designed to identify the high-level challenges to achieving cleanup progress.

The next section includes FY 2000 EM Corporate Performance Measures, Management Commitment High Visibility Project Milestones and Critical Few Performance Measures.

The Key Integration Activities section follows next, highlighting PHMC activities that cross contractor boundaries and demonstrate the shared value of partnering with other Site entities to accomplish the work. Concluding the Executive Summary, a forward-looking synopsis of Upcoming Planned Key Events is provided.

Note: Milestones tracked and reported in this report consist of two Department of Energy levels. In descending order these levels are: 1) Department of Energy-Headquarters (HQ), and 2) Richland Operations (RL). Because it is also useful to distinguish milestones based on specific drivers, the Site applies a designation for those milestones created or tracked to meet the requirements of Enforceable Agreements (EAs). When a milestone satisfies both an EA requirement and a milestone level, it is categorized as both. However, in order to avoid duplicate reporting, this report accounts for each milestone only once. Where an overlap exists between EA and a level (i.e., HQ or RL), the milestone is reported as EA. Additionally, Tri-Party Agreement (TPA) Major and Interim milestones are EA milestones, TPA target milestones are not.

\section{Top 5 Accomplishments for FY 2000}

\section{STABILIZATION AND PACKAGED PLUTONIUM - FOUR MAJOR PROCESSES ON LINE}

- Quadrupled thermal stabilization rates for plutonium (Pu) oxides (658 items in FY 2000 versus 150 items in FY 1999) using 5 muffle furnaces.

- The startup operation of the magnesium hydroxide $\left[\mathrm{Mg}(\mathrm{OH})_{2}\right]$ precipitation process, initiated September 20 , is converting potentially volatile plutonium nitrate acid solutions to a stable oxide form thereby reducing a significant safety risk. Startup of the process is the culmination of months of precise and integrated preparations in what was a very aggressive schedule.

- Operation of an automated state-of-the-art system known as the Bagless Transfer System (BTS) began September 30, 2000, at the Plutonium Finishing Plant. This system accelerates 
packaging capabilities and reduces radiation exposure through automated packaging of plutonium-bearing material in welded stainless steel containers for long term storage.

- The accelerated startup of the plutonium residues packaging process (Pipe'n'Go) was accomplished on September 11 through successful negotiations between the Department of Energy, Fluor Hanford Inc., and the Washington State Department of Ecology. This process packages imported Rocky Flats ash in preparation for future shipment to the Waste Isolation Pilot Plant (WIPP) in New Mexico (Momentum).

\section{COMPLETED SNF CONSTRUCTION, EQUIPMENT INSTALLATION / TESTING}

- Completed construction activities on new nuclear cleanup and storage facilities: Canister Storage Building (CSB), Cold Vacuum Drying Facility (CVDF), and major modifications on K West Basin. Construction of the Interim Storage Area (ISA) adjacent to the CSB was also completed.

- Implemented a strategy to conduct early testing of K West Fuel Retrieval System and Integrated Water Treatment System reducing schedule risk for fuel movement and improving projected fuel production rates in FY 2001.

- Cleared three sections of the T Plant Canyon deck for future acceptance of SNF sludge. This represents significant progress toward readying $\mathrm{T}$ Plant and supports completion of sludge removal one-year ahead of schedule (Progress).

\section{TREATED/DISPOSED WASTE AND MATERIALS}

- Shipped all 184 T-hoppers containing approximately 667 metric tons of low-enriched uranium in the form of uranium trioxide powder to the DOE Portsmouth site in Ohio by the due date of September 28, 2000. This represents approximately one-third of the total unirradiated uranium inventory stored on the Hanford Site at the beginning of FY 2000.

- Shipped 89 drums of TRU waste, the first three of 2,500 shipments scheduled over the next 30 years, to the Waste Isolation Pilot Plant in Carlsbad, New Mexico.

- Treated or direct disposed of 1,204 $\mathrm{m}^{3}$ of Mixed Low Level Waste (MLLW), surpassing the FY 2002 goal and completing Tri-Party Agreement (TPA) milestone M-19-00 eighteen months early. MLLW treatment produced $1,940 \mathrm{~m}^{3}$ of free space in the Central Waste Complex (Completion and Removal).

\section{REMOVED HIGHLY RADIOACTIVE WASTE FROM 300 AREA}

- Key 327 Building cleanup was accomplished, which included packaging and shipping: $32.5 \mathrm{~m}^{3}$ of bulk waste (exceeding the fiscal-year target); 103 legacy waste buckets (28 more than planned); and 90 percent of the 297 sample cans of radioactive materials from dry storage. All eight fuel pins were packaged and shipped; cleanout of $\mathrm{H}$ Cell was completed; and all accountable fissile material in hot cells packaged and shipped.

- 324 B Cell Cleanout (2A Rack Removal and Size Reduction) was completed three weeks early, and $1 \mathrm{~A} 3-82 \mathrm{~B}$ cask shipments were completed seven days early, with all 17 grout containers scheduled for FY 2000 shipped (Momentum). 


\section{ACHIEVED SAFE WORK HOURS RECORD}

- Fluor Hanford, its projects, affiliate companies, and lower tier subcontractors have achieved more than 10 million hours worked since the last Lost Away Workday injury. These hours have accumulated from December 15, 1999 to November 1, 2000 and represent the best Hanford and one of the best DOE complex records (Progress).

\section{Performance Data AND ANalysis}

he following provides a brief synopsis of overall PHMC Environmental Management (EM)
cost, schedule, and milestone performance.

\section{FY 2000 Cost and Schedule Performance}

Cost Performance - FY 2000 year end cost performance reflects a 3.7 percent ( $\$ 21.9$ million) favorable cost variance that is within the established $+10 /-5$ percent threshold. Four projects outside the threshold and contributing to the favorable cost variance are Waste Management, River Corridor, Landlord, and National Programs. Detailed variance analysis explanations can be found in the Project Sections.

Schedule Performance - There is a FY 2000 year end 1.5 percent ( $\$ 8.9$ million) unfavorable schedule variance that is within the established $+10 /-7.5$ percent threshold. One project outside the threshold and contributing to the unfavorable schedule variance is Technology Development. Detailed variance analysis explanations can be found in the Project Sections. 


\section{Baseline Performance Status \\ FY 2000 COSt / SCHEDUle PERformanCe - All Fund TyPes Cumulative to Date Status (\$M)}

DATA THROUGH SEPTEMBER 30, 2000

\begin{tabular}{|c|c|c|c|c|c|c|}
\hline & \multicolumn{5}{|c|}{ Current Fiscal Year Performance ( $S \times$ Million) } \\
\hline & & \multicolumn{3}{|c|}{ FYTD } & \multirow{2}{*}{$\begin{array}{l}\text { Schedule } \\
\text { Variance } \\
\end{array}$} & \multirow{2}{*}{$\begin{array}{c}\text { Cost } \\
\text { Variance }\end{array}$} \\
\hline & & BCWS & BCWP & ACWP & & \\
\hline \multicolumn{2}{|c|}{ The Plateau } & & & & & \\
\hline 1.2 & $\begin{array}{c}\text { Waste Management } \\
\text { TP02,WM03-05 }\end{array}$ & 117.0 & 115.0 & 102.2 & $(2.0)$ & 12.8 \\
\hline 1.2 .4 & $\begin{array}{l}\text { Analytical Svcs (222-S,HASP,WSCF) } \\
\text { WM06 }\end{array}$ & 28.3 & 27.6 & 26.5 & $(0.7)$ & 1.1 \\
\hline 1.4 .5 & $\begin{array}{l}\text { Nuclear Materials Stabilization } \\
\text { TP05 }\end{array}$ & 123.9 & 123.1 & 124.5 & $(0.8)$ & (1.4) \\
\hline & Subtotal The Plateau & 269.2 & 265.7 & 253.2 & (3.5) & 12.5 \\
\hline \multicolumn{2}{|c|}{ The River } & & & & & \\
\hline 1.4 & $\begin{array}{l}\text { River Corridor } \\
\text { TP01,TP04,TP08,TP10,TP12,TP14 }\end{array}$ & 58.1 & 60.5 & 51.9 & 2.4 & 8.6 \\
\hline 1.3 & $\begin{array}{l}\text { Spent Nuclear Fuel } \\
\text { WM01 }\end{array}$ & 201.8 & 198.2 & 201.7 & $(3.6)$ & (3.5) \\
\hline 1.12 & Advanced Reactors (EM) & 1.7 & 1.7 & 2.2 & $(0.0)$ & $(0.5)$ \\
\hline & Technology Development & 23.9 & 21.5 & 20.0 & $(2.5)$ & 1.4 \\
\hline & Subtotal The River & 285.4 & 281.8 & 275.8 & (3.6) & 6.0 \\
\hline \multicolumn{2}{|c|}{ The Future } & & & & & \\
\hline & $\underset{\text { HM01 }}{\text { HAMMER }}$ & 5.9 & 5.8 & 5.4 & $(0.1)$ & 0.4 \\
\hline & Subtotal The Future & 5.9 & 5.8 & 5.4 & $(0.1)$ & 0.4 \\
\hline \multicolumn{2}{|c|}{ Multiple Outcomes } & & & & & \\
\hline 1.5 & $\begin{array}{l}\text { Landlord } \\
\mathrm{TP}_{13}\end{array}$ & 16.3 & 15.3 & 13.7 & $(1.0)$ & 1.7 \\
\hline 1.8 & $\begin{array}{l}\text { Mission Support } \\
\text { OT01 }\end{array}$ & 25.5 & 24.7 & 25.2 & $(0.9)$ & $(0.5)$ \\
\hline $\begin{array}{l}1.11 \& \\
\text { WM07 }\end{array}$ & $\begin{array}{l}\text { National Programs } \\
\text { OT02, WM07 }\end{array}$ & 6.0 & 6.2 & 4.3 & 0.2 & 1.8 \\
\hline & Subtotal Multiple Outcomes & 47.8 & 46.2 & 43.2 & $(1 \mathrm{l} 7)$ & 2.9 \\
\hline & Total PHMC Projects & 608.4 & 599.5 & 577.6 & (8.9) & 21.9 \\
\hline
\end{tabular}

Notes:

Column headings [Budgeted Cost of Work Scheduled (BCWS), Budgeted Cost of Work Performed (BCWP), etc.] are defined in the glossary at the end of the report. Calculations are based on Project Baseline Summary detail. Waste Management, Analytical Services, River Corridor, and Nuclear Materials Stabilization have included RL-Directed costs (e.g. steam and laundry) in the Project Execution Module (PEM) BCWS. Technology Development does not include ORP/RPP TTPs currently reported in the RL Dataset in PEM. 
Funds Management - Although earned value measures are close to or within established thresholds, the PHMC previously projected a potential overrun in the Project Completion Control Point. Project Fiscal Year Spend Forecast (FYSF) data continued to be analyzed in comparison to available funds. Management's aggressive steps designed to correct the possible overrun were effective. In addition, an internal reprogramming transferred $\$ 5 \mathrm{M}$ from the Post 2006 control point to the Project Completion control point and RL identified supplemental funds of $\$ 2.94 \mathrm{M}$ for the Project Completion control point. As of October 6, a number of other solutions including the reclassification of the 300 Area Accelerated Cleanup Plan and Hanford fire costs to the Post 2006 control point totally mitigated the potential spending variance and resulted in an underrun of approximately $\$ 4.0 \mathrm{M}$.

\section{FUNDS MANAGEMENT FUNDS VS. SPENDING FORECAST $(\$ 000)$ (FLUOR HANFORD, INC. ONLY)}

Data Through September 2000

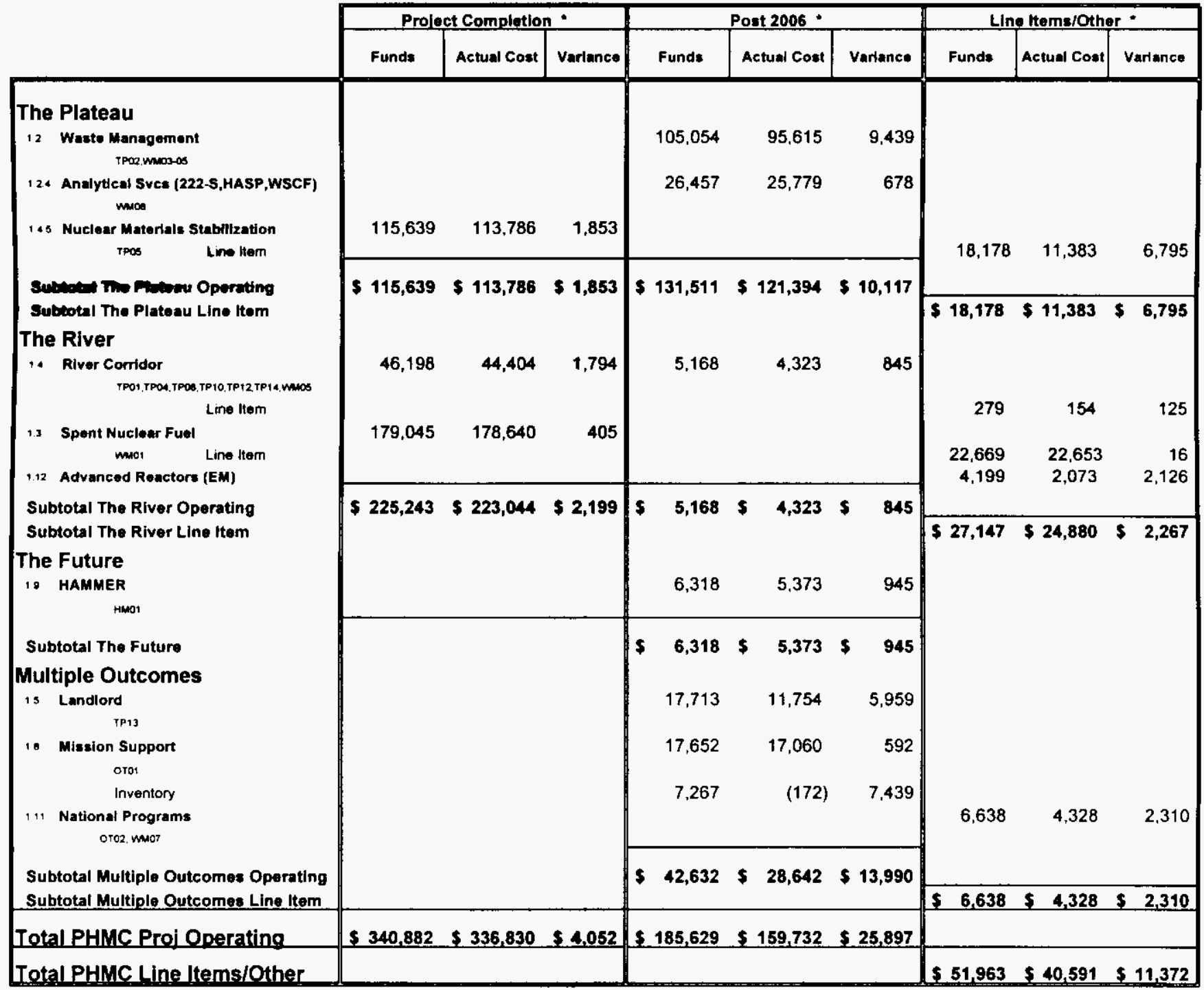

Notes: This chart reflects FH Project structure, which divides certain PBS's (WM05 and TP12) between projects.

This breakout is necessary to provide FH project managers with information specific to their areas of responsibility 


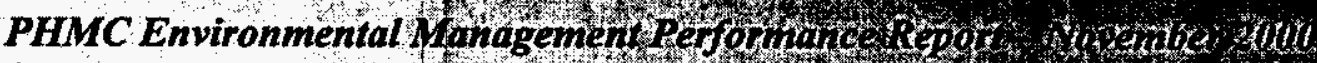 \\ Section A-Executive Swhmary}

and accountability and to facilitate effective management of the funds within their control (obligated to the PHMC). Consequently, these figures will differ from those shown elsewhere in this report (as generated in the PEM system). For purposes of funds management, the "Other" category includes all funding sources not suitable for redistribution within the Project Completion and Post 2006 control points.

The Mission Support Inventory reflects the estimated reserve needed to accommodate indirect commitments.

The following Cost/Schedule and Variance to Plan chart provides an overall graphical view of fiscal year to date cost and schedule performance.

\section{FY 2000 Cost / SChedule Performance Cumulative to Date Status}

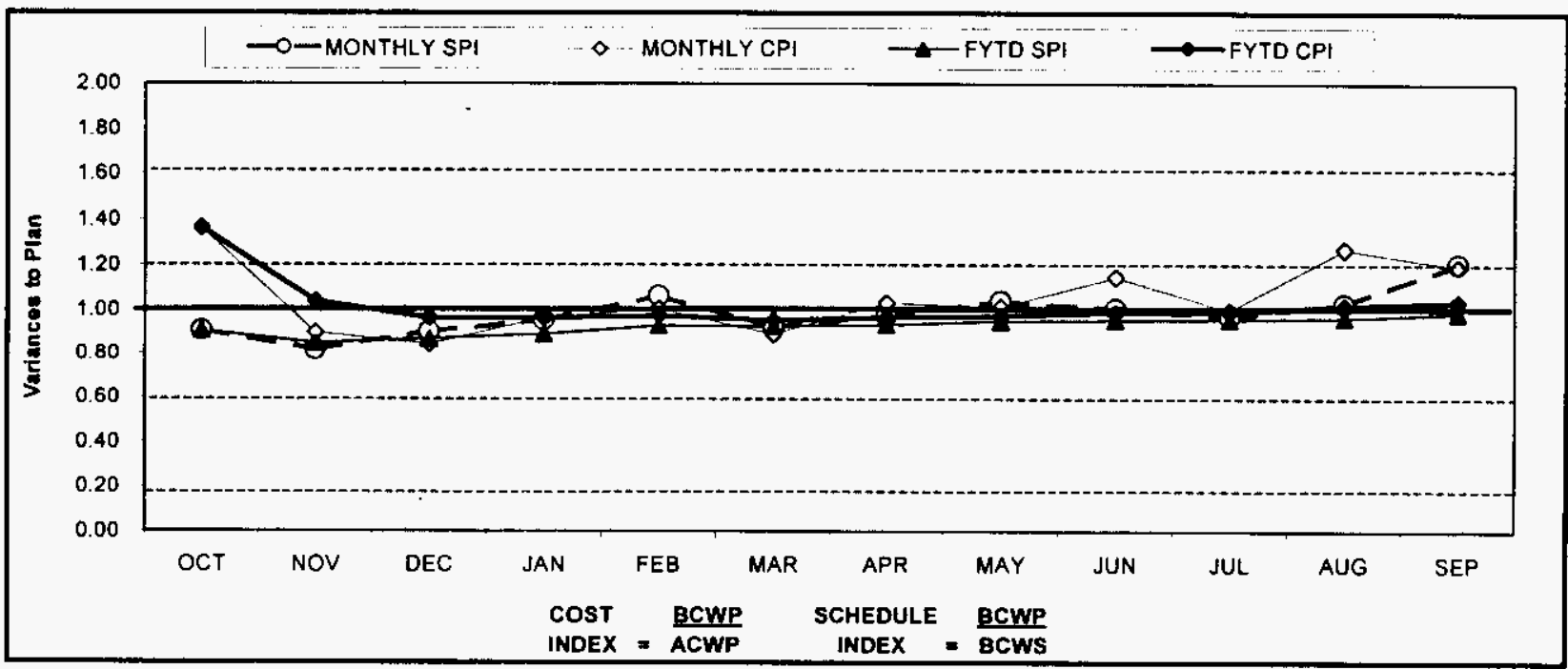

\begin{tabular}{|c|c|c|c|c|c|c|c|c|c|c|c|c|}
\hline FY 2000 & OCT & NOV & DEC & JAN & FEB & MAR & APR & MAY & JUN & JUL & AUG & SEP \\
\hline MONTHLY SPI & 0.90 & 0.82 & 090 & 0.95 & 106 & 092 & 0.97 & 1.04 & 1.00 & 097 & 102 & 120 \\
\hline MONTHLY & 1.36 & 090 & 084 & 0.96 & 1.00 & 089 & 1.03 & 1.01 & 1.15 & 1.00 & 2.27 & 1.19 \\
\hline FYTD SPI & 090 & 085 & 0.87 & 089 & 0.93 & 092 & 093 & 095 & 095 & 096 & 0.96 & 0.99 \\
\hline FYTD CPI & 1.36 & 104 & 0.96 & 0.96 & 0.97 & 0.95 & 096 & 0.97 & 099 & 0.99 & 102 & 103 \\
\hline MONTHLY BCWS & 32,549 & 53,749 & 43,002 & 46,580 & 47,980 & 59,420 & 52,063 & 62,362 & 46,232 & 43,122 & 4,121 & 55,018 \\
\hline MONTHLY BCWP & 29,438 & $5 \quad 43,863$ & 38,748 & 44,295 & 50,947 & 54,698 & 50,649 & 64,618 & 46,358 & 41,741 & 65,686 & 66,252 \\
\hline MONTHLY ACWP & \$ 21,600 & S 49,006 & 45,973 & 46,037 & 50,745 & $6 t, 462$ & 49,182 & 63,799 & 40,470 & 41,919 & 51,768 & 55,618 \\
\hline FYTD BCWS & 32,549 & S 86,298 & $5 \quad 129,299$ & 175,880 & 223,860 & 283,280 & 335,344 & s 397,706 & 443,938 & 487,060 & 551,180 & 606,198 \\
\hline FYTD BCWP & 29,438 & 573,302 & $5 \quad 112,049$ & 156,344 & 207,291 & 261,990 & 312,639 & 377,257 & 5423,615 & 465,356 & 531,042 & 597,294 \\
\hline FYTD ACWP & $5 \quad 21,600$ & s 70,600 & S 116.579 & $5 \quad 162,616$ & 213,361 & 274,823 & 324,005 & 387,804 & $5 \quad 428,274$ & 470,193 & 521,961 & 577,579 \\
\hline
\end{tabular}

\section{Milestone Performance}

Milestones represent significant events in project execution. They are established to provide a higher level of visibility to critical deliverables and to provide specific status about the accomplishment of these key events. Because of the relative importance of milestones, the ability to track and assess milestone performance provides an effective tool for managing the PHMC EM cleanup mission.

FYTD milestone performance (Enforceable Agreement [EA], U.S. Department of EnergyHeadquarters [DOE-HQ], and RL) shows that 86 of 101 ( 85 percent) approved baseline milestones were completed on or ahead of schedule, 11 milestones (11 percent) were completed late, and 4 milestones (4 percent) are overdue. The four overdue milestones are associated with three projects: Nuclear Material Stabilization (Section C: 1)-two, Spent Nuclear Fuel (Section D)- 
one, and River Corridor (Section C: 2)-one. These overdue milestones do not share a common cause.

In addition to the FY2000 milestones described above, there are three overdue milestones [(Waste Management (Section B: 1) and Nuclear Materials Stabilization Projects (Section C: 1)] from the prior fiscal year (FY1999). Further details regarding these milestones may be found in the referenced Project Sections.

FY 2000 information is depicted graphically below and on the following page. For additional details related to the data in the graphs and prior year milestones, refer to the relevant project section titled "Milestone Exception Report."

FY 2000 information reflects the current approved baseline. Changes in both the number and type of milestones from month to month are the result of Baseline Change Requests (BCRs) approved during the year.

\section{TOTAL ALL HANFORD PROJECTS}

MILESTONE ACHIEVEMENT

\begin{tabular}{|c|c|c|c|c|c|c|c|c|}
\hline \multirow[b]{2}{*}{ MILESTONE TYPE } & \multicolumn{4}{|c|}{ FISCAL YEAR-TO-DATE } & \multicolumn{3}{|c|}{ REMAINING SCHEDULED } & \multirow[b]{2}{*}{$\begin{array}{c}\text { TOTAL } \\
\text { FY } \\
2000\end{array}$} \\
\hline & $\begin{array}{c}\text { Completed } \\
\text { Early }\end{array}$ & $\begin{array}{c}\text { Completed } \\
\text { On } \\
\text { Schedule }\end{array}$ & $\begin{array}{c}\text { Completed } \\
\text { Late }\end{array}$ & Overdue & $\begin{array}{c}\text { Forecast } \\
\text { Early }\end{array}$ & $\begin{array}{c}\text { Forecast On } \\
\text { Schedule }\end{array}$ & $\begin{array}{c}\text { Forecast } \\
\text { Late }\end{array}$ & \\
\hline Enforceable Agreement & 27 & 5 & 0 & 0 & 0 & 0 & 0 & 32 \\
\hline DOE-HQ & 0 & 1 & 0 & 1 & 0 & 0 & 0 & 2 \\
\hline$R L$ & 44 & 9 & 11 & 3 & 0 & 0 & 0 & 67 \\
\hline Total Project & 71 & 15 & 11 & 4 & 0 & of & 0 & 101 \\
\hline
\end{tabular}

\section{Total Project}
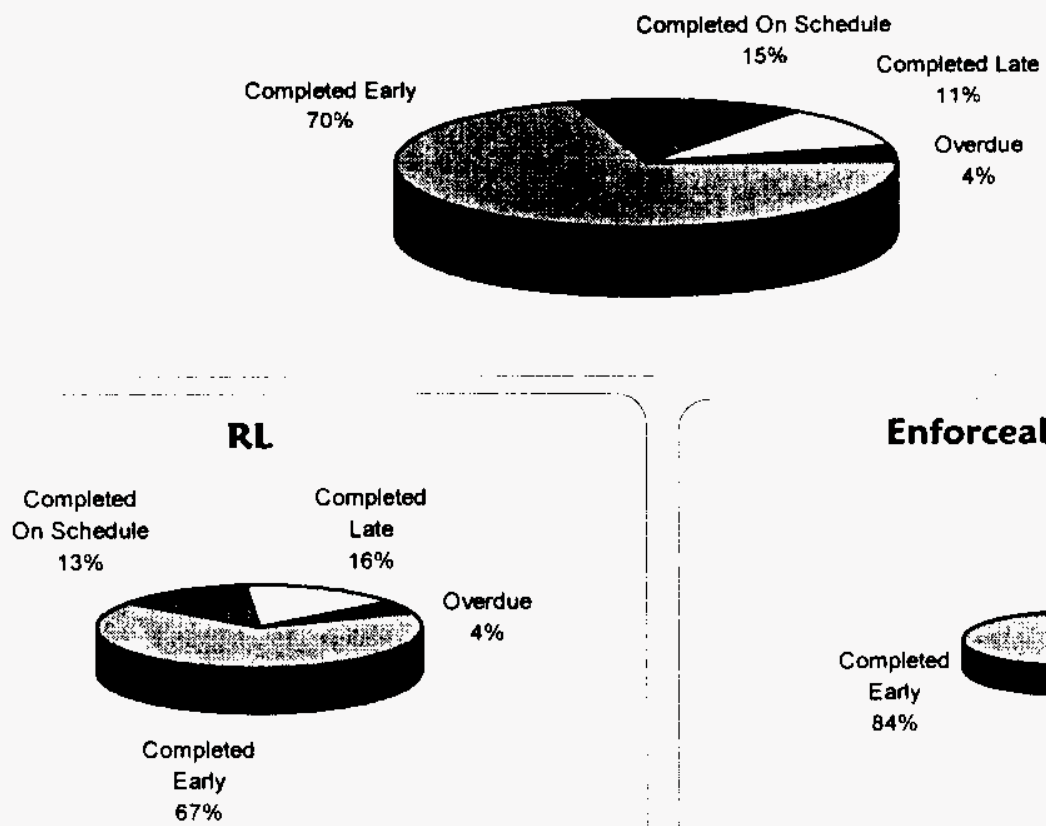

Enforceable Agreement

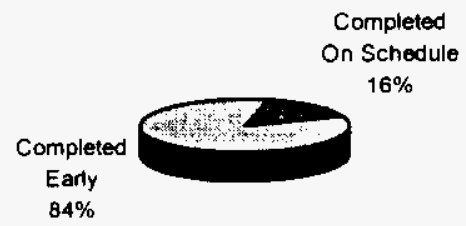


MILESTONE EXCEPTIONS
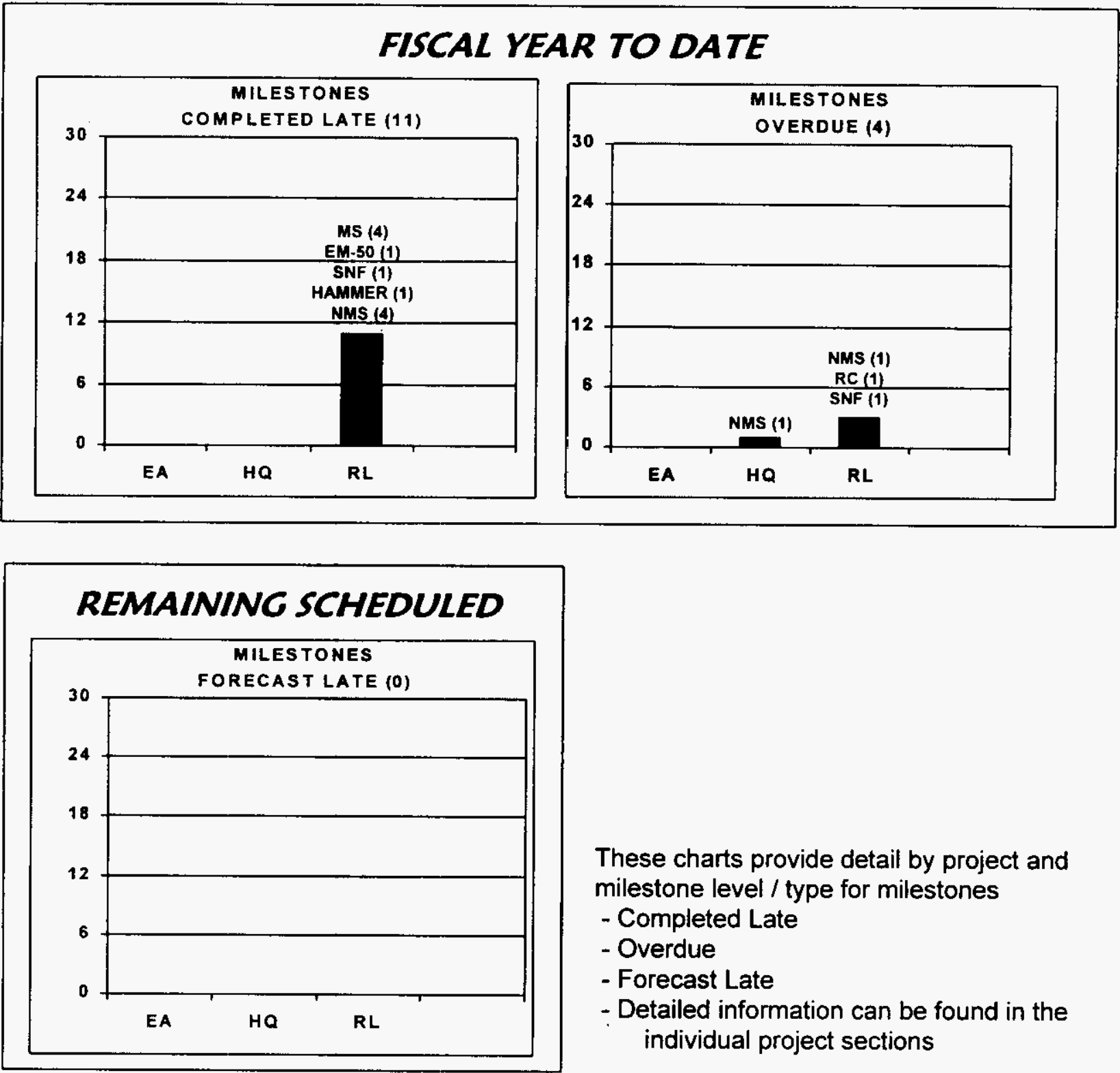

These charts provide detail by project and milestone level / type for milestones

- Completed Late

- Overdue

- Forecast Late

- Detailed information can be found in the individual project sections 


\section{SAFETY OVERVIEW}

$\mathrm{T}$ he focus of this section is to document trends in occurrences. Improvements in these rates are due to the efforts of the PHMC workforce as they implement the Integrated ES\&H Management System (ISMS), work towards achieving Voluntary Protection Program (VPP) "star" status, and accomplish work through Enhanced Work Planning (EWP). Safety and health statistical data is presented in this section.

\section{Significant Safety and Health EVENTS}

The Waste Management (WM) Project has demonstrated a significant improvement in their OSHA recordable case rate and has recently achieved One Million Safe Work hours without a lost workday case.

The Analytical Services (AS) Project has had a significant increase in the OSHA recordable case rate in the fourth quarter of FY 2000. AS has been conducting ergonomic evaluations to reduce workplace injuries, and will report findings at the October Presidents' Zero Accident Council Meeting.

The Nuclear Material Stabilization (NMS) Project DOE Safety Cost Index and Lost Away Workday Case Rate are zero. The Employee-led Zero Accident Council has been instrumental in the improvement in workplace safety.

The River Corridor (RC) Project OSHA Recordable Case Rate remains low, however, there has been a significant increasing trend with four cases during June 2000 through August 2000. RC has recently achieved 1 Million Safe Work hours without a lost workday case.

The Spent Nuclear Fuels (SNF) Project OSHA Recordable case rate is stable. There had been signs of improvement in the middle of FY 2000, but it was not significant and has returned to the existing baseline rate.

The Landlord (LL) Project Lost Away Case Rate is very good, and LL is close to exceeding 2 million safe work hours. LL may be showing some signs of improvement in their OSHA recordable case rate, but it is not yet significant.

Due to space constraints, FY1996 data is not portrayed on the following graphs. 


\section{Total OSHA Recordable Case Rate}

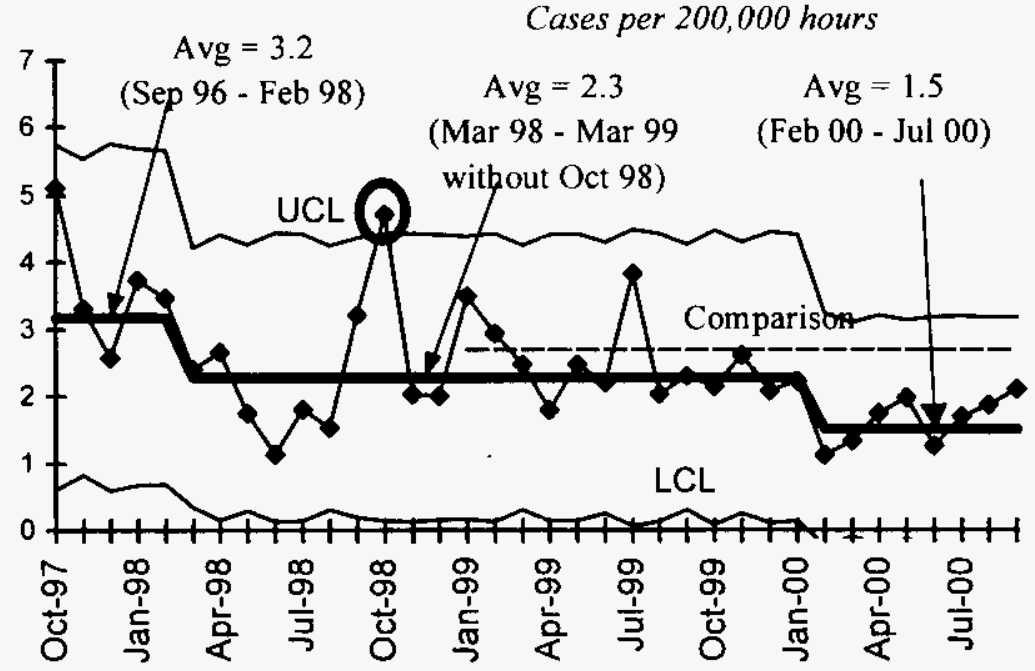

FY $1999=2.7$

FY $2000=1.8$

Contractor Comparison

Average $=2.7($ CY99)

Recent data have been stable within the new 1.5 baseline. The FH Team continues to look for opportunities for injury reduction in the areas of ergonomics and lacerations.

FH implemented a program to target an OSHA Recordable Case Rate of 0.9. The Fluor Global Services goal is 1.0. This is in line with Fluor's corporate value of safety and our commitment to the safe clean-up of the Hanford Site.

\section{OSHA LOST/RESTRICTED WORKDAY CASE RATE}

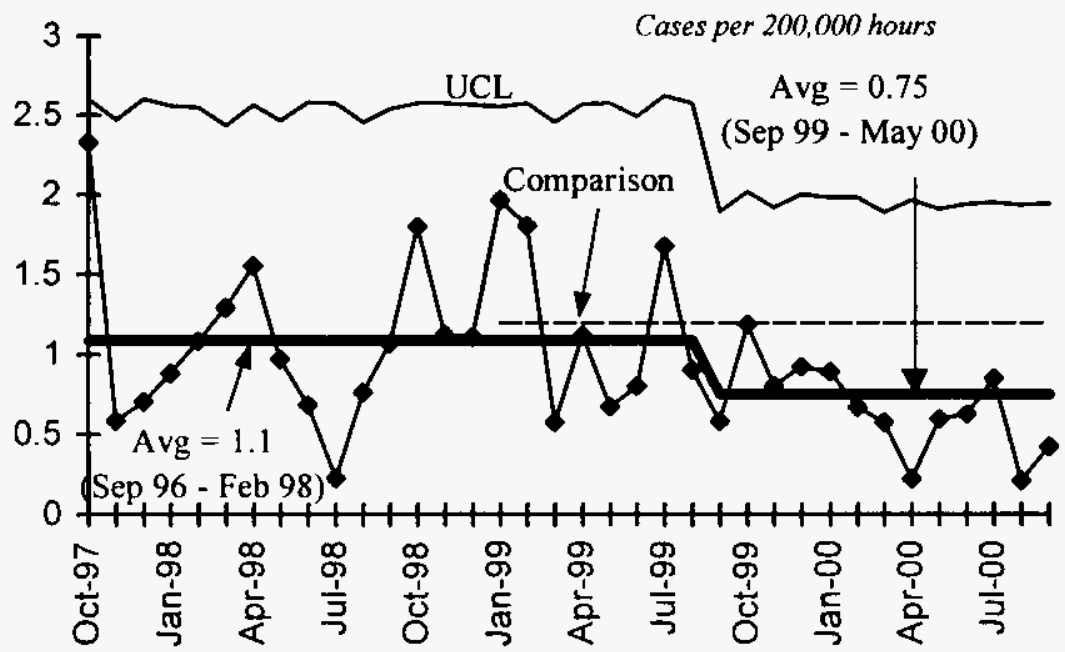

FY $1999=1.15$ Green
Contractor Comparison Average $=1.2$ (CY99)

Data continue to be at or below the current baseline average established for September 1999 - May 2000, but is not yet a significant trend.

As of November 1, the FH Team accumulated over 10 million safe work hours since mid-December 1999 without any new lost away workday cases. 


\section{First Aid Case Rate}

\section{Green}

Cases per 200,000 hours

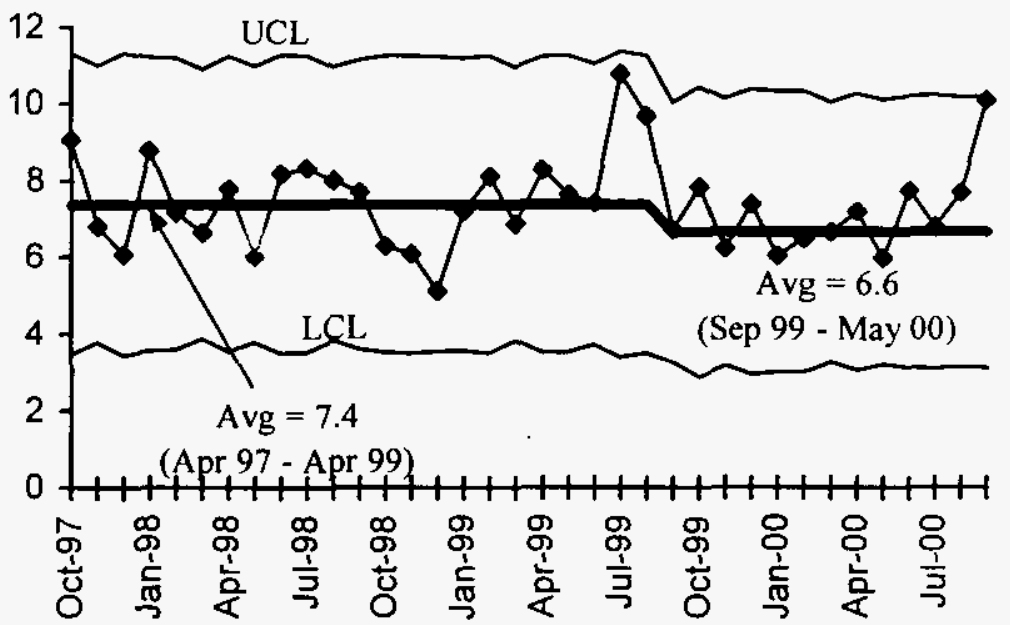

First Aid Rate undergoes seasonal cycles. Increases occur in warmer weather due to insect and animal encounters, and due to wind related minor injuries. First Aid case rate has remained relatively stable, a good indicator that injuries are not being under-reported.

There was a nearly significant increase in September 2000 , but the increase appears to be primarily related to summer increases in insect and wind hazards. Past activities to increase awareness of wind hazards and actions to control insects and animals appear to be having an effect.

The hazard of receiving wind-borne debris in eyes when working outdoors has considerably increased due to the bare, exposed sand left by the Hanford wildfire.

\section{DOE Safety Cost Index}

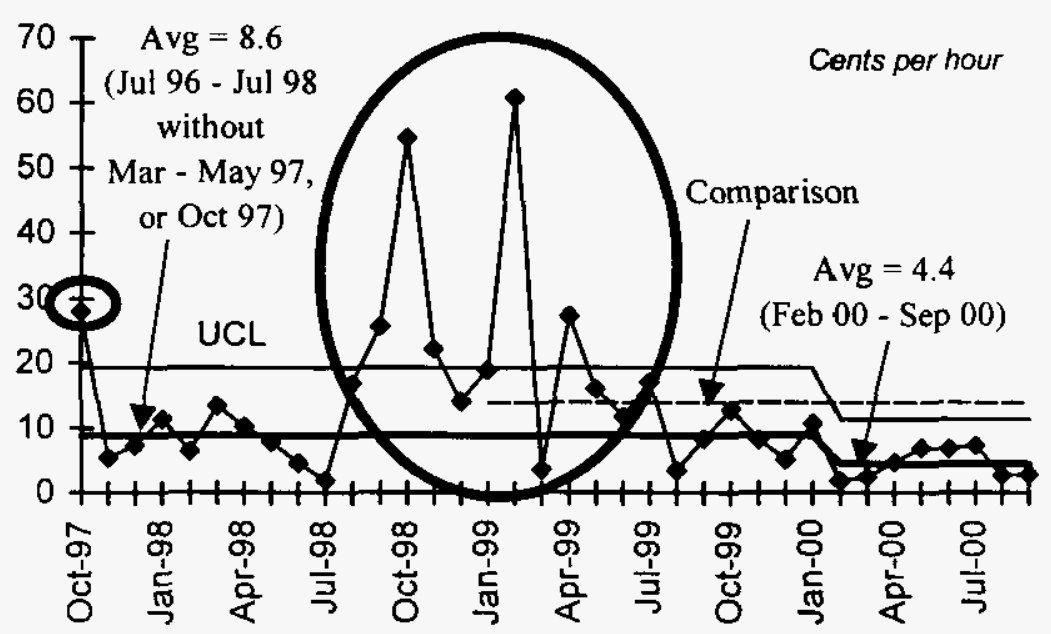

FY $1999=21$

FY 2000 to date $=5.9$

Contractor Comparison Average $=$ 13.9 (CY99)

This indicator has had new average and control limits calculated reflecting recent significant decreases in the cost index. This decrease is primarily related to the reduction in Lost Away workday injuries.

Past data continue to be corrected as further days accumulate on any work restrictions or lost days.

\section{CritTical ISSUES}

- INABILITY TO MEET ACCEPTANCE CRITERIA DELAYS CELL CLEANUP Hot spots on the bottom of Steel Waste Disposal Boxes loaded with Rectangular Grout Containers from the 324 Building are more radioactive than the current Central Waste Complex (CWC) acceptance criteria of $1 \mathrm{R}$. The shipment schedule/in-cell work schedule has been delayed, but several actions are being pursued. See the River Corridor Project Section C: 2 for more information. 


\section{em Corporate Performance Measures}

\begin{tabular}{|c|c|c|c|c|}
\hline Performance Measures & $\begin{array}{l}\text { EM Management } \\
\text { Commitment }\end{array}$ & $\begin{array}{c}\text { FY } 2000 \text { Current } \\
\text { Baseline } \\
\end{array}$ & $\begin{array}{l}\text { FY } 2000 \\
\text { Planned } \\
\end{array}$ & $\begin{array}{c}\text { FY } 2000 \\
\text { Actual } \\
\end{array}$ \\
\hline \multicolumn{5}{|l|}{ Facilities Deactivated/Decommissioned } \\
\hline Facilities deactivated & $2 !$ & 21 & 21 & 25 \\
\hline Facilities decommissioned & 13 & 13 & 13 & 23 \\
\hline \multicolumn{5}{|l|}{ TRansUranic (TRU) Waste } \\
\hline Stored - total inventory $\left(\mathrm{m}^{3}\right)$ & 16,333 & 16,316 & 16,316 & 16,407 \\
\hline Disposed (shipped to DOE site $\mathrm{m}^{3}$ ) & 55 & 55 & 51 & 19 \\
\hline \multicolumn{5}{|l|}{ High Level Waste } \\
\hline Stored - total inventory $\left(\mathrm{m}^{3}\right)$ & 4 & 2 & 2 & 2 \\
\hline Treated $\left(\mathrm{m}^{3}\right)$ & 3,600 & 3,600 & 3,600 & 5,070 \\
\hline \multicolumn{5}{|l|}{ Mixed Low Level Waste } \\
\hline Stored - total inventory $\left(\mathbf{m}^{3}\right)$ & 7,852 & 7,852 & 7,852 & 7,677 \\
\hline Treated $\left(\mathrm{m}^{3}\right)$ & 1,060 & 1,060 & 1,060 & 1,204 \\
\hline Disposed & 835 & 835 & 835 & 666 \\
\hline \multicolumn{5}{|l|}{ Low Level Waste } \\
\hline Stored - total inventory $\left(\mathrm{m}^{3}\right)$ & 180 & 180 & 180 & 298 \\
\hline Disposed (on-site/commercial) $\left(\mathrm{m}^{3}\right)$ & 6,936 & 6,936 & 6,936 & 8,079 \\
\hline \multicolumn{5}{|l|}{ Material Stabilized } \\
\hline Plutonium Oxide (cans) & 400 & 140 & 140 & 574 \\
\hline Plutonium Solution (L) & 255 & 255 & 255 & 67 \\
\hline Plutonium Residue (kg) & 29 & 29 & 29 & 17 \\
\hline Technology Deployments & 9 & 9 & 5 & 17 \\
\hline \multicolumn{5}{|l|}{ Pollution Prevention } \\
\hline HAZ (MT) & 45 & 45 & 45 & 19 \\
\hline SAN (MT) & 1,781 & 1,781 & 1,781 & 986 \\
\hline $\operatorname{LLW}(\mathrm{m} 3)$ & 470 & 470 & 470 & 218 \\
\hline MLLW $(\mathrm{m} 3)$ & 138 & 138 & 138 & 120 \\
\hline \multicolumn{5}{|l|}{ Cleanup/Stabilized Waste Avoided } \\
\hline FY 2000 planned baseline amount $\left(\mathrm{m}^{3}\right)$ & 1,920 & 1,920 & 1,920 & 7,280 \\
\hline FY 2001 planned baseline amount $\left(\mathrm{m}^{3}\right)$ & 1,926 & 1,926 & N/A & $\mathrm{N} / \mathrm{A}$ \\
\hline
\end{tabular}

All of the above reflect the FY2000 year-end status. For deviations $+/-10$ percent, see the following projects sections: Facilities Deactivated, Facilities Decommissioned (Landlord); TRU Disposed, HLW Treated, MLLW Treated, MLLW Disposed, LLW Stored, LLW Disposed (Waste Management Project); Materials Stabilized - Plutonium Oxide, Solution and Residue (Nuclear Materials Stabilization Project) and Technology Deployments (EM-50).

Pollution Prevention (National Programs) - PNNL generated approximately $27 \mathrm{mT}$ less of Hazardous Waste (HAZ) then in FY99 as a result of various actions taken in the past few years to minimize HAZ waste generated (i.e., Pollution Prevention Opportunity Assessments, Return on Investment [ROI] implementation, material substitution, and inventory reduction). SAN, LLW and MLLW reflects waste reduction resulting from recycling, ROI implementation, and source reduction. Waste Avoided (National Programs) - The Cleanup/Stabilized Waste Avoided goal to reduce all waste by 10 percent $\left(1,920 \mathrm{~m}^{3}\right)$ was greatly exceeded. The documented waste was reported at $7,280 \mathrm{~m}^{3}$ through various processes and uses. 
PHMC Environmental Managenent Per ow w

Section A-Executive Summary.

em Management Commitment Milestones as Of SePtember 30, 2000

\begin{tabular}{|c|c|c|c|c|}
\hline 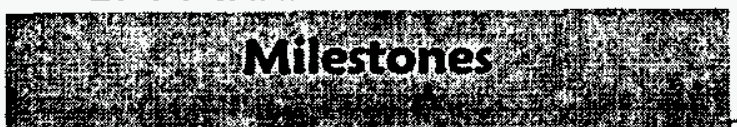 & $\begin{array}{l}\text { Due } \\
\text { Date }\end{array}$ & Forecast & $\begin{array}{l}\text { Actual } \\
\text { Date }\end{array}$ & comments \\
\hline 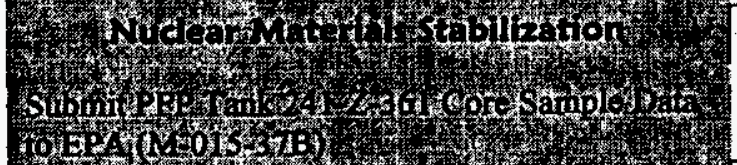 & $5 / 31 / 00$ & 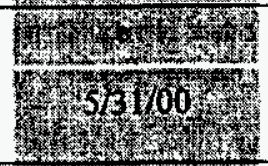 & $5 / 31 / 00$ & \\
\hline B.7. & $7 / 31 / 00$ & 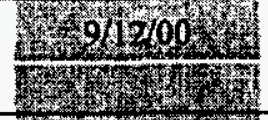 & $9 / 20 / 00$ & \\
\hline 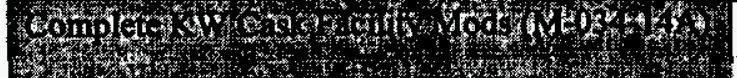 & $2 / 29 / 00$ & 3. 202900 & $2 / 29 / 00$ & \\
\hline (6) & $5 / 31 / 00$ & Miragoctobey & $10 / 19 / 00$ & \\
\hline 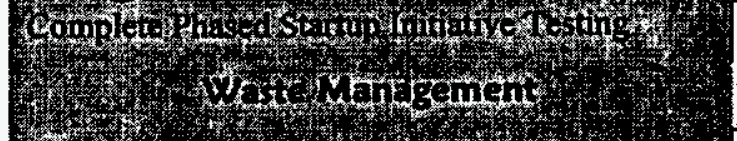 & $8 / 31 / 00$ & 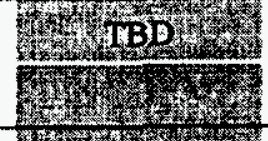 & & $23 x-3$ \\
\hline 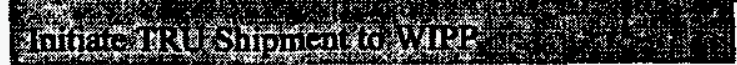 & & $7 x+120$ & $7 / 12 / 00$ & \\
\hline
\end{tabular}

\section{Critical Few Performance Measures}

Performance Measure

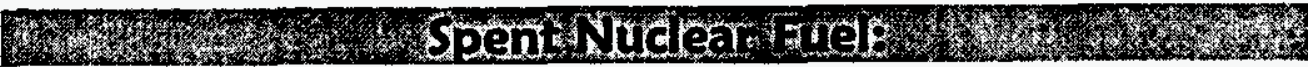

Measure - Amount of fuel removed

Declaration of Readiness to move Spent Nuclear Fuel

Phased Startup Initiative Phases I \& II

Measure - Amount of SNF Stabilized

- 3247327 Builitiog Deactiation:

Measure - Number of buildings dispositioned

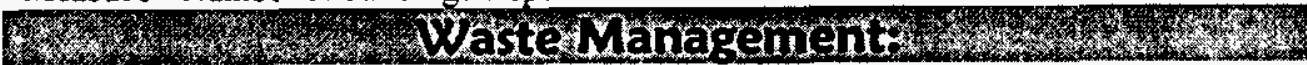

Measure - Adequacy of waste management services support

Number of analytical equivalent units (AEU's) analyzed

Through-put efficiency of effluent treatment facility (ETF) gpm

Number of 242-A evaporator campaigns completed

Measure - Retrieve and ship TRU offsite

Number of drums retrieved

Number of shipments to WIPP

Measure - MLLW Treated (m3)

Measure - MLLW Disposed (m3)

Measure - Clear three T-Plant canyon deck sections

Measure - Remove two PUREX separation towers

Thitonium stabilization:

Measure - Pu metal/oxides/other types dispositioned (items)
Data Through

September $\mathbf{2 0 0 0}$

Red

Red

NA FY 2000

Green

Green

Green

Green

Green

Green

Green

Green

Green

Green

Yellow

Yellows noted above are behind schedule but recoverable. Red is either missed or unrecoverable. Details can be found in the Project Sections. 


\section{KEY INTEGRATION ACTIVITIES}

The following are the key technical integration activities that are currently underway and cross project/contractor lines. These activities are being addressed by inter-discipline and interproject groups and demonstrate that Hanford Site contractors are working together to accomplish the EM Clean up mission.

- Waste Management (WM) continues working with RL, DOE-HQ and other Sites to develop and define Hanford's role in disposing of waste from other sites. Hanford's role as one of the identified LLW/MLLW disposal sites for the Complex is yet to be fully defined.

- WM supporting the Office of River Protection Waste Treatment Plant.

- WM supporting visits from both the DOE-Idaho Program Office and the Office of the Inspector General in regards to opportunities for treatment/disposal of Idaho National Engineering Environment Laboratory (INEEL) wastes at Hanford.

- WM continues working with PNNL, EM-50 and Mixed Waste Focus Area (MWFA) to obtain funding in support of mixed waste processing.

- Analytical Services continues to support ORP efforts to establish required analytical support for Waste Treatment Plant (WTP) design and operation.

- Through involvement with the National Facility Deactivation Initiative, Hanford, Rocky Flats, and Savannah River are working to submit a joint proposal for a contaminated large equipment size reduction system deployable at the three sites.

- Spent nuclear fuel (SNF) final disposition interface activities, including Office of Civilian Radiation Waste Management (OCRWM) Quality Assurance (QA) Program implementation, is ongoing with the National SNF Program. The SNF Project submitted eight Corrective Action Closure packages to RL for National SNF Program approval.

- SNF Project Programmatic Agreement with River Corridor Project for 324 Building (B Cell) fuel removal was approved.

- The SNF Project and Waste Management Project continued preparations for K Basins' sludge removal and Shippingport (PA) Pressurized Water Reactor Core 2 SNF removal.

- Bechtel Hanford, Inc. transmitted the transfer plan for SNF discovered during upcoming 105F and $105 \mathrm{H}$ reactor basins deactivation to SNF Project for review and approval. 


\section{Upcoming Planned Key Events}

The following Key events are extracted from the authorized baseline and are currently expected

1 to be accomplished during the next several months. Most are Enforceable Agreement (EA),

HQ or DNFSB Milestones.

Waste Management:

- Accelerate Readiness to Receive Spent Nuclear Fuel K Basin Sludge.

- Complete procedures, training, and Operations Readiness Review (ORR) by June 2001.

- Complete entire T Plant deck clearing in FY 2001.

- Complete safety basis documentation and long lead procurements in FY 2001.

- Install handling, drying and loading equipment in FY 2001.

Analytical Services

- Dr. Steven Bakhtiar of Analytical Services is chairing the $46^{\text {th }}$ Annual Bioassay, Analytical, and Environmental Radiochemistry (BAER) Conference in Seattle in mid-November 2000.

\section{Nuclear Materials Stabilization:}

- Complete installation and startup of the Supercritical Fluids Extraction equipment for Loss-onIgnition moisture measurement in the first quarter of FY 2001.

- Initiate metal processing in the first quarter of FY 2001.

- Receive delivery of the 2736-ZB BTS and Outer Can Welder (OCW) during the second quarter of FY 2001.

- Initiate alloys and polycube stabilization in third quarter of FY 2001.

\section{River Corridor Project:}

- Complete Removal of 324 Building Radiochemical Engineering Cell (REC) B Cell Mixed Waste (MW) and Equipment in the first half of FY 2001.

- Implement technical update of 324 Authorization Basis (Safety Analysis Report) by midDecember, 2000 and implement technical update of 327 Authorization Basis (Basis of Interim Operation) by March, 2001.

- Complete Facility Evaluation Board review during first quarter of FY 2000.

- Complete shipment of approximately 235 metric tons of excess uranium billets and approximately 5 metric tons of uranium dioxide to the DOE Portsmouth site in Ohio by March 31,2001 and disposition approximately 140 metric tons of surface contaminated uranium fuel by June $30,2001$.

- Complete shipment of B Cell waste currently stored in A Cell to the 200 Areas in July 2001.

\section{Spent Nuclear Fuels:}

- Begin K West Basin fuel removal, drying and storage operations by November 30, 2000.

- Start K West Basin canister cleaning in December 2000.

- Complete K East Basin Sludge Loadout conceptual design in January 2001.

- Complete K East Basin Integrated Water Treatment System (IWTS) definitive design in April 2001 .

\section{Landlord}

- Complete Project L-309, "Replace Main Water Lines" by December 22, 2000.

- Complete installation of a chlorine containment system for Project L-303, "200 West Area Chlorine Mitigation" by January 31, 2001. 

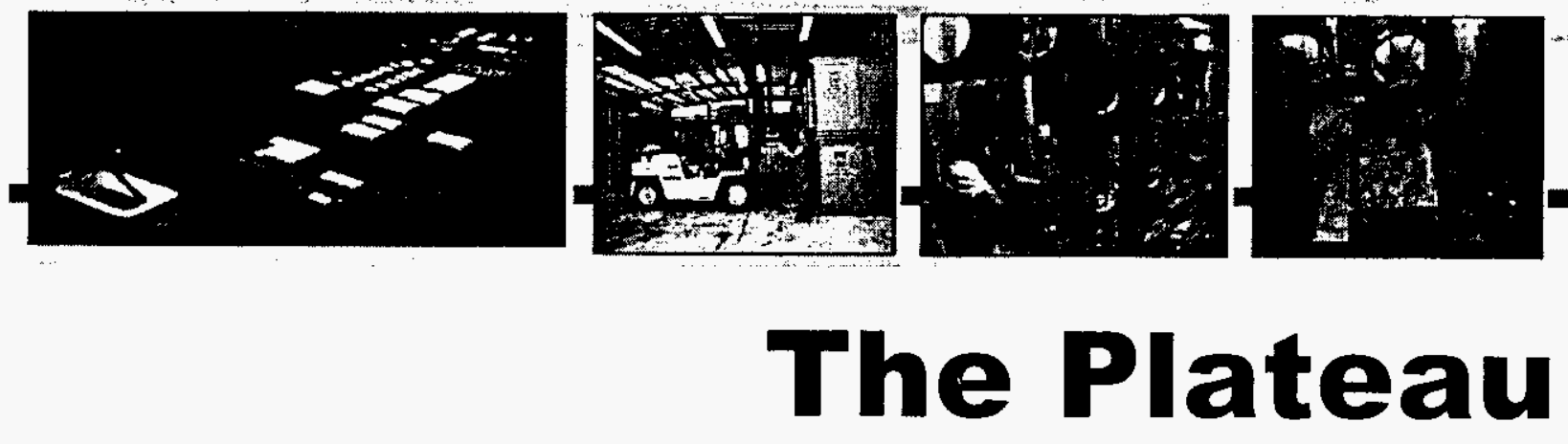

Transitioning the central plateau for long-term waste management is a key part of the Hanford vision. Determining the disposition of the "canyon" facilities, deactivating the Plutonium Finishing Plant and disposing of solid waste are the desired outcomes. Projects included in The Plateau are Waste Management, Analytical Services, and Nuclear Material Stabilization. 

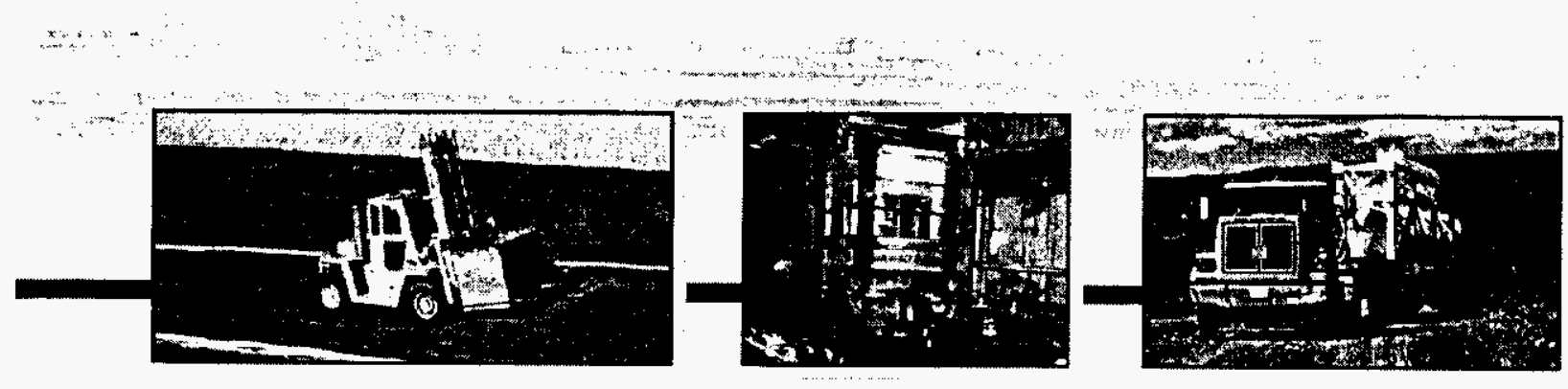

\section{Section B:1 Waste Management}

\section{PROJECT MANAGERS}

G.H. Sanders, RL (509) 376-6888

E.S. Aromi Jr., WMH

(509) 372-1033 


\section{SUMMARY}

Waste Management consists of the Solid Waste Storage and Iisposal, Project Baseline Summary (PBS) WM03, Work Breakdown Structure (WBS) 1.2.1: Solid Waste Treatment. PBS WMOt. WBS 1.2.2: I.iquid Iffluents - 200 Area. PBS WM05. WBS 1.2.3.1: and the Waste Encapsulation and Storage Facility, PBS TP()2, WBS 1.4.2.

PBS WM05 is divided between WBS 1.2.3.1, Liquid Fffluents (200 L.L1) and WBS 1.2.3.2. 310 TEDF/340 Facility (300 LEF). The 310 TEDF/340 Facility work scope is now included in the River Corridor Project, whereas the Liquid Effluents (200 LIF) work scope has remained in Waste Management. For the purpose of performance analysis. PBS WM05 is reported in its entirety in the Waste Management Project (WMP). which has the majority of the work scope and funding.

NO'IE: Unless otherwise noted, the Safety, Conduct of Operations, Milestone Achievement, and Cost/Schedule data contained herein is as of September 30,2000. Other data is updated as noted.

\section{Top 5 Accomplishments for FY 2000}

The Project completed all FY 2000 milestones on or ahead of schedule. In addition. all Performance Incentive commitments, including stretch goals, were completed (Momentum).

The first three shipments of Hanford transuranic (TRU) waste for disposal at the Waste Isolation Project Plant (WIPP) were completed. Certification of the Ilanford TRU Program was achieved with the Carlsbad Field Office (CFO) and the New Mexico Environment Iepartment (NMI:I)). This certification is necessary for these and future waste shipments (Completion and Removal).

Treatment or direct disposal of 1,204 $\mathrm{m}^{3}$ of Mixed I ow Level Waste (MLI.W) was completed. surpassing the FY 2002 goal and completing Tri-Party Agreement (TPA) milestone M-19-(00. MLI.W treatment produced $1,940 \mathrm{~m}^{3}$ of free space in the Central Waste Complex (Completion and Removal).

Three sections of the $T$ Plant deck were cleared for future acce tance of $k$ Basins sludge in support of the Spent Nuclear Fuels Project (Momentum).

Retrieval and designation of 437 suspect TRU drums ( 12 more than planned) was achieved with the completion of field assaying (Momentum).

\section{Additional FY 2000 Accomplishments}

\section{Moment.im}

WM supported the IOOE-RI, in the declaration of Readiness-to-Proceed for support of the ()ffice of River Protection (ORP) Waste Treatment Plant C'ontract. 
The Waste Minimization and Pollution Prevention expectations asseciated with waste generation, recycling and aftirmative procurement were exceeded.

More than $\$ 8.9 \mathrm{M}$ in cost savings were identified. These savings are a result of efficiencies, favorable passbacks, attrition, and procurements put on hold.

A new in-trench technology was deployed where concrete grout is injected around the Category 3 LI,W. The new technology results in higher waste loading in the burial grounds, reduced construction costs. and reduced future burial ground closure and monitoring costs.

\section{Progress}

The Site groundwater was protected by treating over 17 million gallons of radioactive/hazardous wastewater at the 200 Area Fffluent Treatment Facility (ICTF). ORP was supported by processing over 1.3 million gallons of tank waste through the $242 \mathrm{~A}$ Evaporator. The Total Operational Efficiency of 99.3 percent was the highest ever achieved. An operational savings of $\$ 1.2$ million was achieved by campaigning 200 Area ETF and $242 \mathrm{~A}$ Evaporator operations.

\section{Completion and Removal}

A total of $8.079 \mathrm{~m}^{3}$ of low-level waste was disposed in the Low-Level Burial Grounds including $6,582 \mathrm{~m} 3$ from off-site, versus a planned $6,936 \mathrm{~m} 3$

Fiscal year milestone performance (EA, DOE-HQ and RL) shows that ten milestones (100 percent) were completed. Nirle of the milestones were completed ahead of schedule, including the two Enforceable Agreement milestones. Overall Project performance is superior. Cost and schedule goals for fiscal year 2000 were met.

\section{Accomplishments this Reporting Period}

The following activities were completed at the Waste Receiving and Processing (WRAP) lacility through September 30, 2000:

- Nondestructive examination of 44 drums (916 fiscal ycar total)

- Radiography on 12 boxes ( 59 fiscal year total)

- Nomdestructive assays of 48 drums (992 fiscal year total)

- Processing of 5 drums thro dgh the Low Level Waste (LLW) repackaging/compaction glovebox 45 fiscal year tota. 


\section{SAFETY}

WMP has achieved nearly one and a half million safe hours. Rates have heen stable for (rver two years. During the month of September, the WMP experienced I Restricted Workday ( ase. 12 first aid cases and 3 "Report Only" cases. OSHA recordable injuries are down from previous levels. The I ost Restricted workday case rate has been below average 7 months in a row. a significant improvement. The OSHA recordable case rate is showing a significant improving trend, with 4 of the past 5 months in a row at one standard deviation below average.

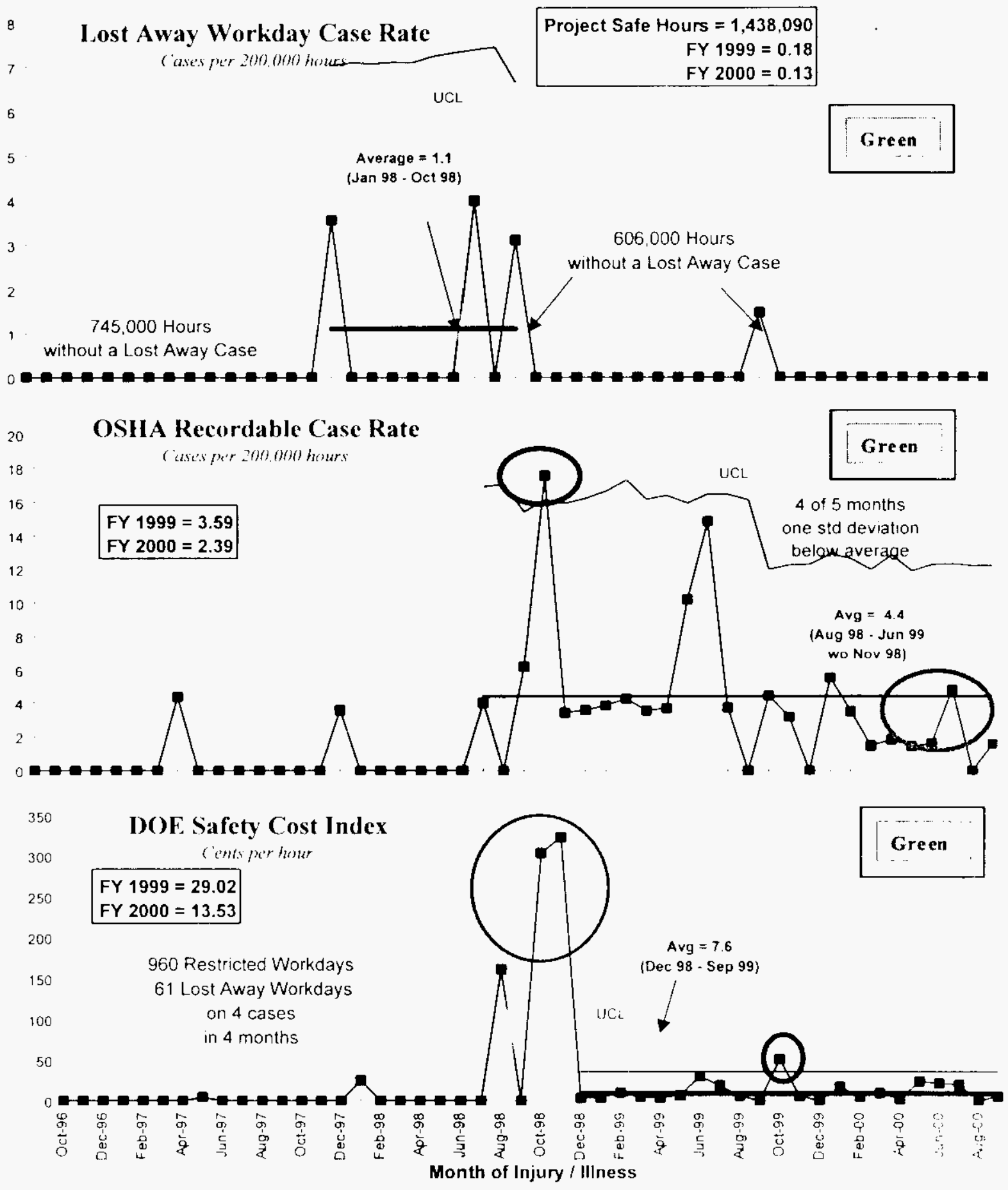




\section{CONDUCT OF OPERATIONS / ISMS STATUS}

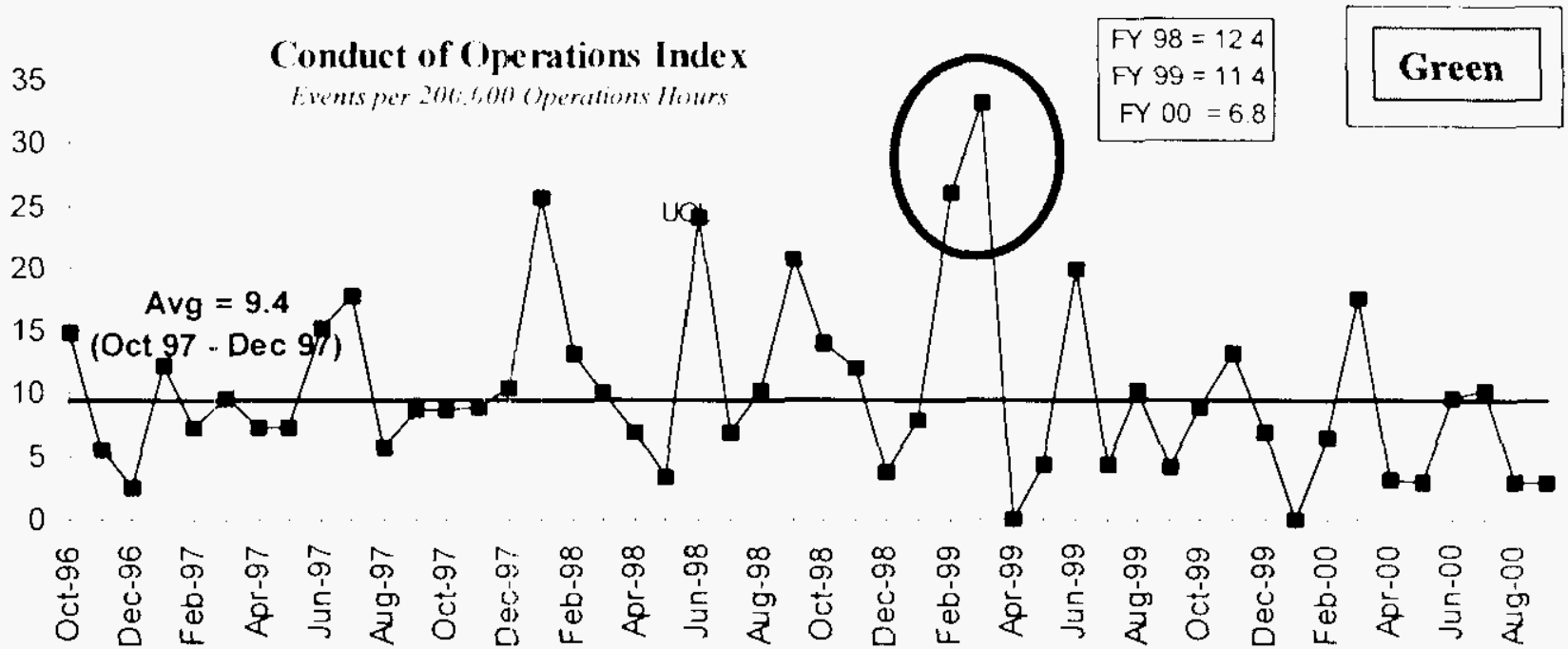

Number of Reports Past 12 Months

$\begin{array}{llllllllllll}0 & 2 & 4 & 6 & 8 & 10 & 12 & 14 & 16 & 18 & 20\end{array}$

Personnel Contarrination

Procedure Violation

Procedure Problem

Trainıng

Management Problem

Lock and Tag

Work: Control

\section{ISMS STATUS}

Green

Completed Activities in FY 2000:

- Established a multi-discipline Core Team of represented and professional stafl to meet an 18 month accelerated schedule

- Identified process gaps through all-employee surveys and self-assessments

- Ieveloped a System Description of ISMS processes and implementing mechanisms used by all WMP facilities

- Partnered with the PHMC l'rojects and RI. to achieve an efficient implementation of integrated management systems

- Developed a WMP-wide document to clarify specitic ISMS roles and responsibilities across the organization

- Developed and received DOI: approval for Authorization Agreements for all five WMP (ategory 2 nuclear facilitic: 
- Successfully completed ISMS Phase I (documentation) and Phase Il (field implementation) verifications conducted by multi-discipline $D()$ l teams

- Prepared and executed corrective action plans resulting from self-assessment. Phasc I. and Phase II verification activities

- Participated in development of PHMC ISMS Sustain and Maintain (Continuous Improvement) Plans for out-years

\section{Planned Action:}

Configuration Control of the WMP portion of the ISMS System Description (MP-(003) document will be detailed and distributed as part of the Project level "sustain and maintain" efforts. The project will implement the Sustain and Maintain Plan for ISMS when approved.

\section{BREAKTHROUGHS / OPPORTUNITIES FOR IMPROVEMENT}

\section{Breakthroughs}

An effort has begun to evaluate the potential for consolidation of planned mixed waste disposal facilities on the Hanford Site. It is possible that considerable savings can be realized if the construction/operations of the Solid Waste mixed waste disposal facility. Immobilized I.ow Activity Waste disposal facility, and the Spent Melter trench can be consolidated. A team is being formed to conduct the assessment of potential savings, and initial discussions are underwiy with CHIM HILL Hanford Group (CHG).

\section{Opportunities for Improvement}

Waste Management Strategic Planning - Revision of the Waste Management Project Strategic Plan is underway. A series of workshops have been conducted with the Iepartment of Energy, the Washington State Iepartment of Ecology, and the IS Environmental Protection Agency. The objective of the effort is to update and improve the Project strategy. to gain regulator "buy-in." to improve the format and presentation of the Strategy. and to develop a basis for the ongoing production of the Multi-Year Work Plan. A series of logic diagrams and an overall schedule graphic are being developed which will serve to improve the communication of the Waste Management Strategic Plan to users/stakeholders.

Mixed Waste Focus Area (MWFA) - Continue to work with the MWFA (Robitics Product I.ine) on a technology development/demonstration activity at Hanford. The details of at demonstration/deployment of size reduction technologies are being worked out. Initial plans are for a demonstration of size reduction at T Plant in FY 2001. using commercial technologiest to size reduce the PUREX Towers (TRU) currently stored on the canyon deck. This activity supports development of technologies for later application in the M-91 Facility and also clearing of the deck for sludge receipt. Funding for the activity will be provided by the MWF A 


\section{UPCOMING ACTIVITIES}

WIPP C'ertification and Waste Shipments - C'omplete two shipments of I lanford TRI ' waste to Waste Isolation Pilot Plant ( WIPP) before the end of the calendar year.

Remote-Handled TRU Project Management Plan (PMP) - Support RL meetings with Feology to address Ecology s August 14,2000 letter disapproving the PMP.

\section{Accelerate Readiness to Receive Spent Nuclear Fuel K Basin Sludge -}

- Complete entire T' Plant deck clearing in FY 2001.

- Complete safety basis documentation and long lead procurements in FY 2001. Install handling, drying and loading equipment in FY 2001.

- Complete procedures, training, and Operations Readiness Review (ORR) by June 2001.

Land Disposal Restriction (I.DR) Report …. The 45-day primary document comment period on the Interim I.DR report ended on September 14, 2000. A letter was received from licology requesting a two-weck extension (to September 28. 2000) to the comment period. Comments were received and responses are being prepared. Not all of Ecology"s comments will be resolved and the legal appeal over the Final Determination will continue.

\section{Cost Performance ( $\$ M):$}

\begin{tabular}{|l|c|c|c|}
\hline & BCWP & ACWP & VARIANCE \\
\hline Waste Management & $\$ 115.0$ & $\$ 102.2$ & $\$ 12.8$ \\
\hline
\end{tabular}

The $\$ 12.8$ million (11 percent) favorable cost variances are primarily in RL-WM03 Solid Waste Storage and Disposal and RL-WVM05 Liquid Effluents. Further information at the PBS level can be found in the following Cost Variance Analysis.

\section{Schedule Performance ( $\$ M)$ :}

\begin{tabular}{|l|c|c|c|}
\hline & BCWP & BCWS & VARIANCE \\
\hline Waste Management & $\$ 115.0$ & $\$ 117.0$ & $-\$ 2.0$ \\
\hline
\end{tabular}

The $\$ 2.0$ million (2 percent) unfavorable schedule variance is within established threshold. Further information at the PBS level can be found in the following Schedule Variance Analysis. 
FY 2000 Cost/SChedule Performance - All Fund Types Cumulative to Date Status - (\$000) FYTD

By PBS

\begin{tabular}{llllllll}
\hline BCWS & BCWP & ACWP & SV & $\%$ & CV & $\%$
\end{tabular}

PBS WMO3

WBS 1.2 .1

Solid Waste Storage \&

Disposa!

$\$ 38,855$

PBS WM04

WBS 1.2.2

Solid Waste Treatment

36,271

$35.476 \$$

$33.031 \$$

(795) $\quad-2^{\circ} \circ \quad \$ \quad 2.445 \quad 7^{\circ} 0$

PBS WM05*

Liquid Effluents -

WBS 1.2 .3

200/300 Area

$\$ 28,909 \$ 28,344$

$24.437 \$$

(565) $-20 \% \$ 3,907 \quad 14^{\circ} \circ$

PBS TP02

WBS 1.4 .2

WESF

$\$ 12,965$

12,835

$12.250 \$$

(130) $-10^{\circ} \$ \quad 585 \quad 5^{\circ} \circ$

Total

$\$ \quad 117,000 \quad \$ \quad 115,028 \quad \$ \quad 102.187$

$\$(1$

(973) $-2 \%$ \% $\$ 12.841 \quad 11^{\circ} \%$

*PBS WM05 includes the 300 Area Liquid Effluent, which is part of the River Corridor Project.

RL-Directed costs (steam and laundry) are included in the Project Execution Module (PEM) BCWS

\section{Cost/Schedule Performance Indices (MONTHLY AND FYTD)}
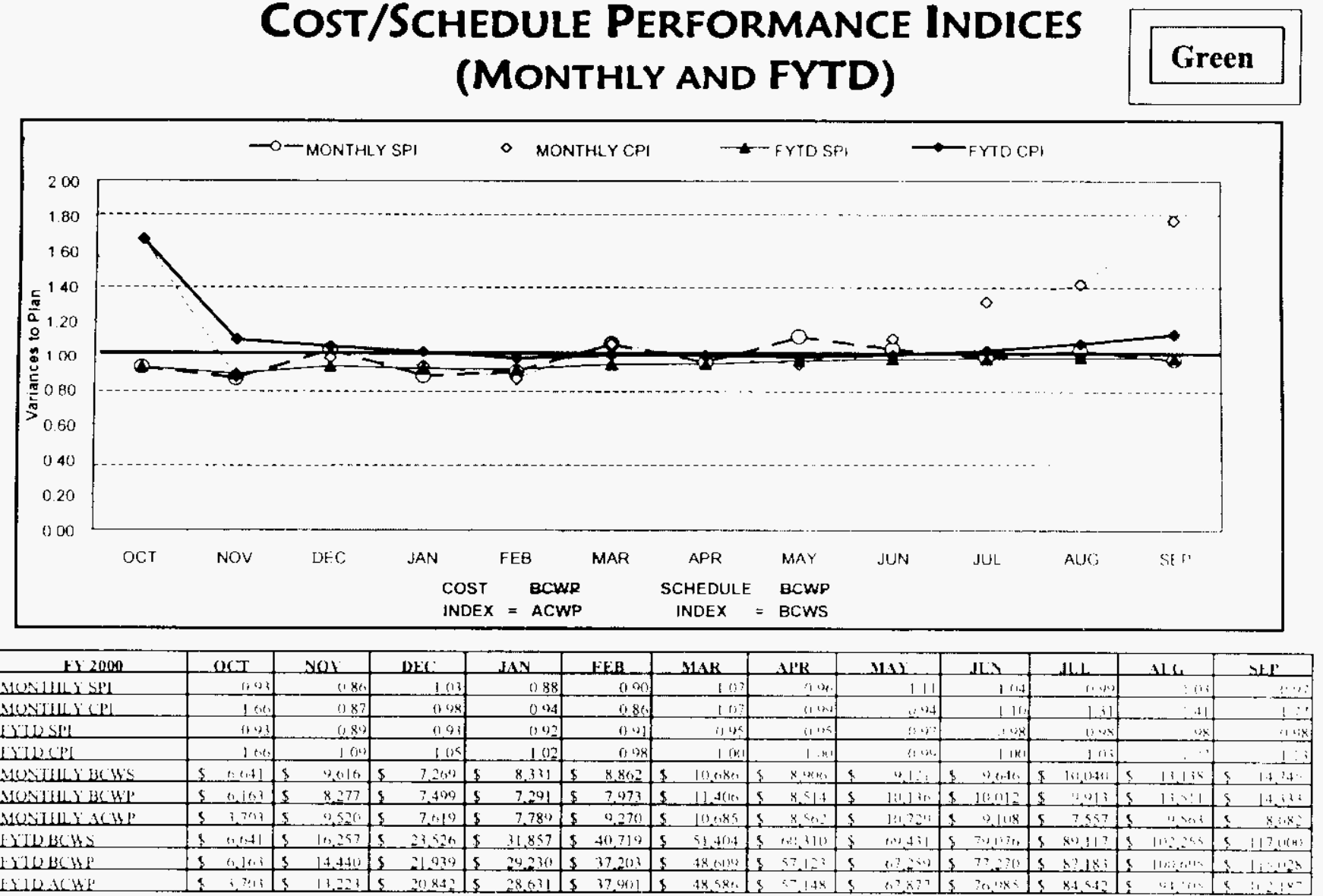


\section{Cost VARIANCE ANalysis: $(+\$ 12.8 \mathrm{M})$}

$\underline{\text { WBS/PBS }}$

1.2.1/WM03

\section{Title}

Solid Waste Storage $\&$ Disposal

Description/Cause: The favorable cost variance of $\$ 5.9 \mathrm{M}(15$ percent $)$ is primarily due to documented efficiencies, staff working on the CSB, favorable passbacks, and reduced lece accrual.

Impact: No impact.

Corrective Action: No action required

1.2.2/WM04

Solid Waste Treatment

Description/Cause: The favorable cost variance of $\$ 2.4 \mathrm{M}$ (7 percent) is within the established threshold.

Impact: No impact.

Corrective Action: No action required.

1.2.3.1/WM05

Liquid Effluents

Description/Cause: The favorable cost variance of $\$ 3.9 \mathrm{M}(14$ percent $)$ is a result of the 200 and 300 Area documented efficiencits, procurements put on hold, favorable passbacks, and attrition.

Impact: No impact.

Corrective Action: No corrective action required.

1.4.2/ТP02

WESF

Description/Cause: The favorable cost variance of $\$ 0.6 \mathrm{M}$ (5 percent) is within the established threshold.

Impact: No impact.

Corrective Action: No corrective action required.

\section{SCHEDULE VARIANCE ANALYSIS: (-\$2.0M)}

\section{WBS/PBS Title}

\subsection{1/ WM03 Solid Waste Storage \& Disposal}

Description /Cause: The unfaverable schedule variance of $\$ 0.5 \mathrm{M}(1$ percent) is within the established threshold.

Impact: No Impact.

Corrective Action: No corrective action required.

\subsection{2/ WM04 Solid Waste Treatment}

Description /Cause: The unfarerable schedule variance of $\$ 0.8 \mathrm{M}(2$ percent) is within the established threshold.

Impact: No Impact.

Corrective Action: No corrective action required. 
PHMC Environmental Management Performance Report-November 2000 Section B: I-Waste Management

\subsubsection{1/WM05 Liquid Effluents}

Description /Cause: The unfavorable schedule variance of $\$ 0.6 \mathrm{M}$ (2 percent) is within the established threshold.

Impact: No Impact.

Corrective Action: No corrective action required.

\subsection{2/ TP02 WESF}

Description /Cause: The unfavorable schedule variance of $\$ 0.1 \mathrm{M}(1$ percent $)$ is within the established threshold.

Impact: No Impact.

Corrective Action: No corrective action required.

\section{FUNDS MANAGEMENT FUNDS VS SPENDING FORECAST ( $\$ 000)$ FY TO DATE THROUGH SEPTEMBER 2000 (FLUOR HANFORD, INC. ONLY)}

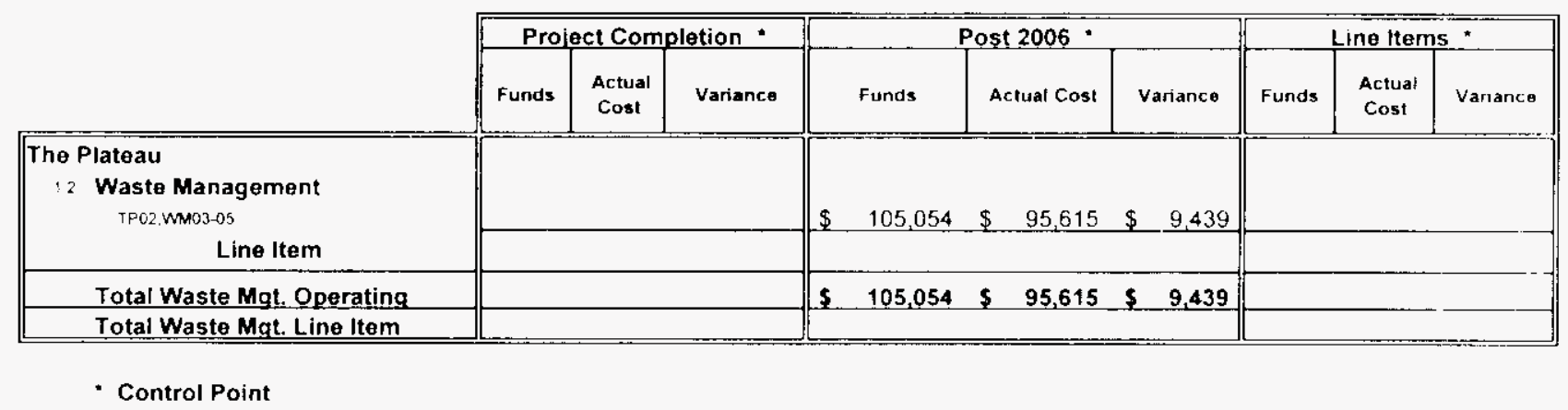

\section{ISSUES}

\section{Technical Issues}

None.

\section{DOE/REGULATOR/EXTERNAL ISSUES}

Interim Report for Hanford Land Disposal Restrictions (LDR) for Mixed Wastes Substantial areas of disagreement still exist between RL and the Washington State Department of Ficology (Fecology) on the required scope and content of the Annual I.DR Submittal as delineated in the Final Determination issued by the Director of Ecology on March 29. 2000. RI is appealing certain aspects of the Ecology requirements, with formalized hearings scheduled for early in calendar year 2001. As a result of Rl.'s July 31.2000 submittal of the L IDR report, Ecology responded with comments in August that stated the report fails to meet requirements of the Final Determination. Responses are currently being prepared. 


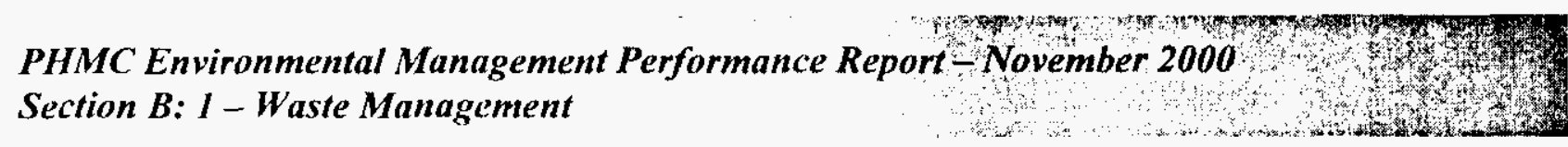

There are still major disagreements with licology over I.DR reporting requirements. The most significant is the definition of "waste," where Lcology wants materials that have not yet been declared waste to be managed as waste including annual reporting. licology submitled "Motion for Partial Summary Judgment" on September 25.2000 to the court in order to attempt to have our appeal of the Final Deternination dismissed. In response. D)()l: submitted a legal document that argued against this position. Talks are underway with Ecology on I.J)R and several other issues in an attempt to reach resolution without litigation.

Hanford Facility (HF) RCRA Permit - The RI. Regulatory Compliance Analysis Division informally proposed to Ecology that the agency incorporate lessons learned from the 222-S Laboratory Complex Part B permit application negotiations into the Central Waste Complex ( $C W C^{\prime}$ ) and Waste Receiving, and Processing (WR $A P$ ) portions of the HF Resource Conservation and Recovery Act of 1976 (RCRA) Permit. This would further delay issuance of Modification E, but would be of great benefit to both facilities. Modification E will incorporate the ( WC and the 616 Non-radioactive I)angerous Waste Storage Facility (NRDWSF) Closure Plan into the R(RA Permit.

Remote-Handled TRU Project Management Plan (PMP) - Ecology disapproved the PMP (TPA milestone M-91-03) on August 14.2000) because the submittal did not meet the requirements set forth in Section 11.5 of the Hanford Federal Facility Agreement and Consent Order (Tri-Party $\Lambda$ greement). Internal meetings with RI are ongoing and meetings with licology occurred in mid-September; a path-forward for resolution of Fcology's concerns with the PMP is being developed based on these discussions.

Impacts of Waste Management PEIS and ROD - The Waste Management Programmatic Environmental Impact Statement (PEIS) was issued on February 25, 2000. The Records of Decision (ROD) for low-level waste and mixed low-level waste will affect Hanford's disposal role for the (omplex and may have a signiticant impact on disposal volumes and rates at Ilanford. I)(OE-HQ and Ecology negotiations continue; impacts depend upon the results of these negotiations.

\section{Baseline Change Requests Currently in Process (\$000)}

\begin{tabular}{|c|c|c|c|c|c|c|c|c|c|}
\hline $\begin{array}{c}\text { PROJECT CHANGE } \\
\text { NUMBER }\end{array}$ & $\begin{array}{c}\text { DATE } \\
\text { CRIGIN. }\end{array}$ & BCR TITLE & $\begin{array}{c}\text { FYOO } \\
\text { COST } \\
\text { IMPACT } \\
\$ 000 \\
\end{array}$ & $\begin{array}{l}\mathrm{S} \\
\mathrm{C} \\
\mathrm{H}\end{array}$ & $\begin{array}{l}T \\
E \\
C \\
H\end{array}$ & $\begin{array}{l}\text { DATE TO } \\
\text { CCB }\end{array}$ & $\begin{array}{c}\text { CCB } \\
\text { APR'VD } \\
\end{array}$ & $\begin{array}{c}R L \\
\text { APR'VD } \\
\end{array}$ & $\begin{array}{l}\text { CURRENT } \\
\text { STATUS }\end{array}$ \\
\hline WMI-2(x) $(1)-(1)$ & $7: 26: 000$ & WA1' EY $2001 \mathrm{MYW}$ Y'Revision & $\$(1)$ & & & $8 / 31 /(x)$ & $4: 25 / 00$ & & $A I \mid x)|R|$ \\
\hline $111-2(x) 1-(10) 1$ & $9 / 1206)$ & Base ops Redustam for I'HMC Projects & $-55,0,36$ & & $x$ & & & & Draft Prepared \\
\hline$[13-2(x)(1](0) ?$ & 1) $25 / 00$ & 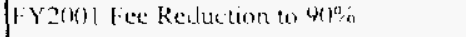 & $-\$ 7.40$ & & & & & & praff Pripated \\
\hline $111-2(n) 1-(16) 3$ & $4: 2500$ & $\begin{array}{l}\text { FY Y } 2(k) 1 \text { Addition of High l'riorits } \\
\text { Workscope }\end{array}$ & 85.6 .30 & & $x$ & & & & 1)ratt l'separed \\
\hline \multicolumn{10}{|c|}{ ADVANCE WORK AUTHORIZATIONS } \\
\hline & & Nothing to report at this time. & & & & & & & \\
\hline
\end{tabular}


Milestone ACHieVEMENT

\begin{tabular}{|c|c|c|c|c|c|c|c|c|}
\hline \multirow[b]{2}{*}{ MILESTONE TYPE } & \multicolumn{4}{|c|}{ FISCAL YEAR-TO-DATE } & \multicolumn{3}{|c|}{ REMAINING SCHEDULED } & \multirow[b]{2}{*}{$\begin{array}{c}\text { TOTAL } \\
\text { FY } 2000\end{array}$} \\
\hline & $\begin{array}{c}\text { Completed } \\
\text { Early }\end{array}$ & $\begin{array}{l}\text { Completed } \\
\text { On Schedule }\end{array}$ & $\begin{array}{c}\text { Completed } \\
\text { Late }\end{array}$ & Overdue & $\begin{array}{c}\text { Forecast } \\
\text { E.arly }\end{array}$ & $\begin{array}{c}\text { Forecast On } \\
\text { Schedule }\end{array}$ & Forecast Late & \\
\hline Enforceable Agreement & $\underline{2}$ & $\underline{0}$ & 0 & 0 & 0 & 0 & 0 & 2 \\
\hline DOE-HQ & 0 & 0 & 0 & 0 & 0 & 0 & 0 & 0 \\
\hline $\mathrm{RL}$ & 7 & 1 & 0 & 0 & 0 & 0 & 0 & 8 \\
\hline Total Project & 9 & 1 & 0 & 0 & 0 & 0 & 0 & 10 \\
\hline
\end{tabular}

Only TPA/EA milestones and all FY2000 overdue and forecast late milestones are addressed in this report. Milestones overdue are deleted from the Milestone Exeeption Report once they are completed. The following chart summarizes the FY2000 IP A/HA milestone achievement and a Milestone Fixception Report follows.

\section{Tri-Party Agreement / EA Milestones}

\begin{tabular}{|c|c|c|}
\hline Number & Milestone Title & Status \\
\hline $\begin{array}{l}\text { M-91-03 } \\
(\text { WMH-00-001) }\end{array}$ & $\begin{array}{l}\text { Issue } \\
\text { IRU/TRUM } \\
\text { Waste PMP }\end{array}$ & due $06 / 30 / 00-($ completed $6 / 29 / 2000($ stretch $)$ \\
\hline $\begin{array}{l}\text { M-91-04 } \\
(\text { A2.J-00-001) }\end{array}$ & $\begin{array}{l}\text { Complete } \\
\text { Construction of } \\
\text { CH TRU/TRUM } \\
\text { Retrieval } \\
\text { Facility }\end{array}$ & $\begin{array}{l}\text { due } 09 / 29 / 00-\text { DOE-RL issued a letter to licology on } \\
\text { February } 29,2000 \text { documenting closure of the TPA } \\
\text { milestone as retrieval has been initiated and is planned to } \\
\text { continue, even without construction of Project } W-113 \\
\text { facilities. }\end{array}$ \\
\hline
\end{tabular}

\section{DNFSB Commitments}

\section{MILESTONE EXCEPTION REPORT}

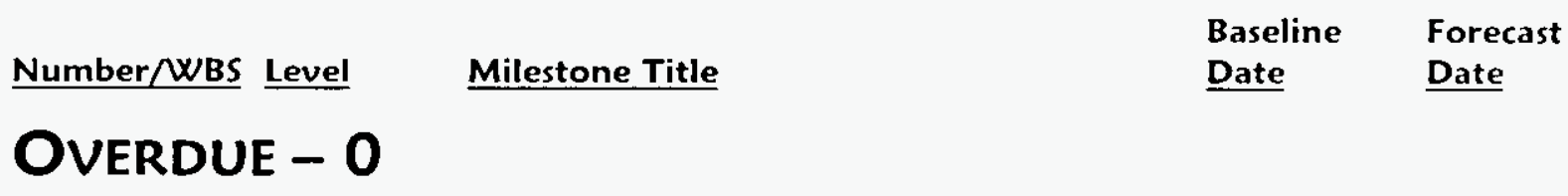

FORECAST LATE - 0

FY 1999 OVERDUE - 1
TRP-98-709 RL
Complete Hot Cell Deactivation
$03 / 31 / 90$
$03 / 30 / 01$

\section{4 .2 \\ WESF Facility (A-E)}

Cause: This milestone is not complete due to not being supported at the current funding level.

Impact: No overall impact is expected.

Corrective Action: Return-on-Investment (ROI) funding has been identified for this work scope and a new forecasted completion date of March 30.2001 established. 


\section{Performance Objectives MLLW TREATMENT}

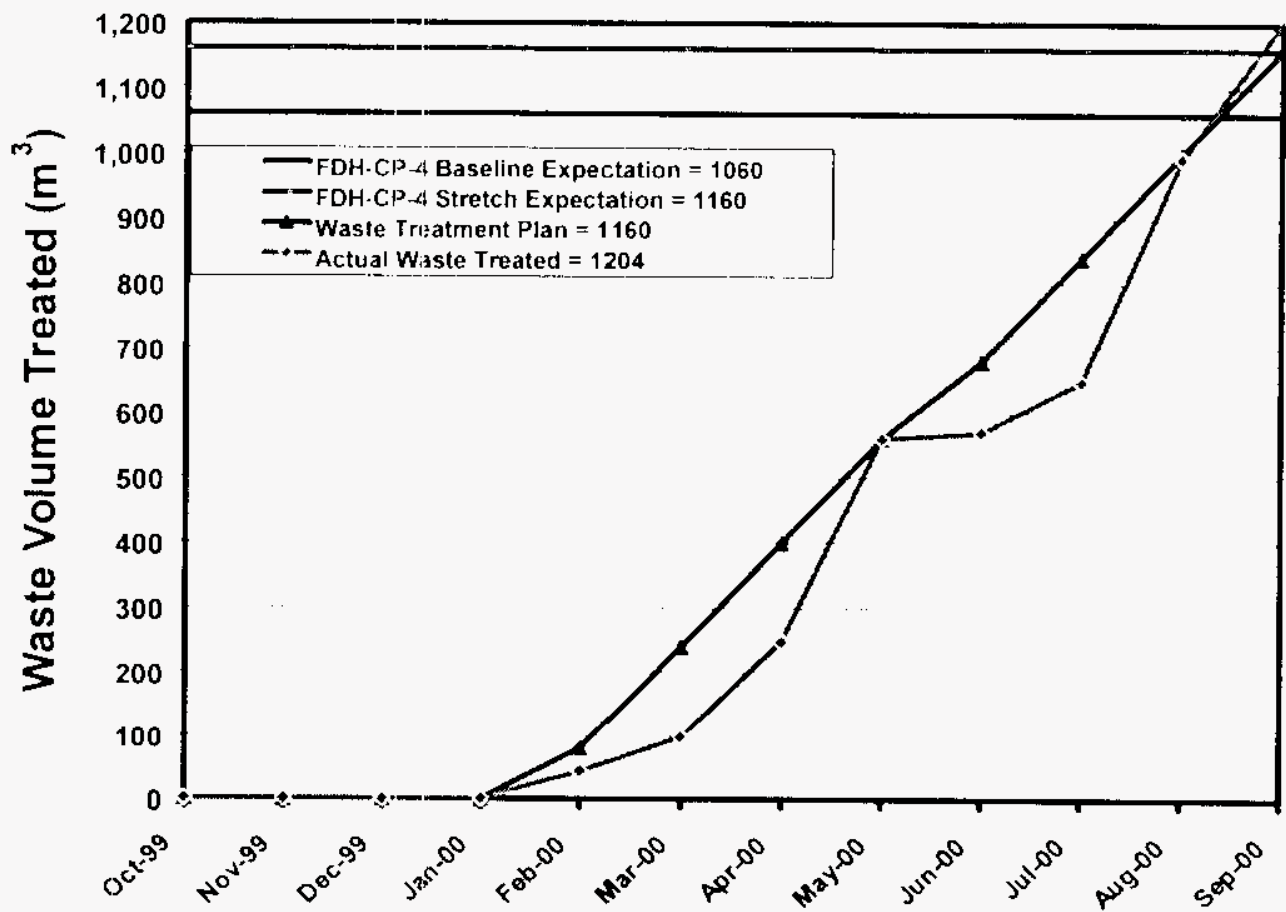

Action Plans: Complete. A total of $1,204 \mathrm{~m}^{3}$ were treated through September 2000 .

MLLW DISPOSAL

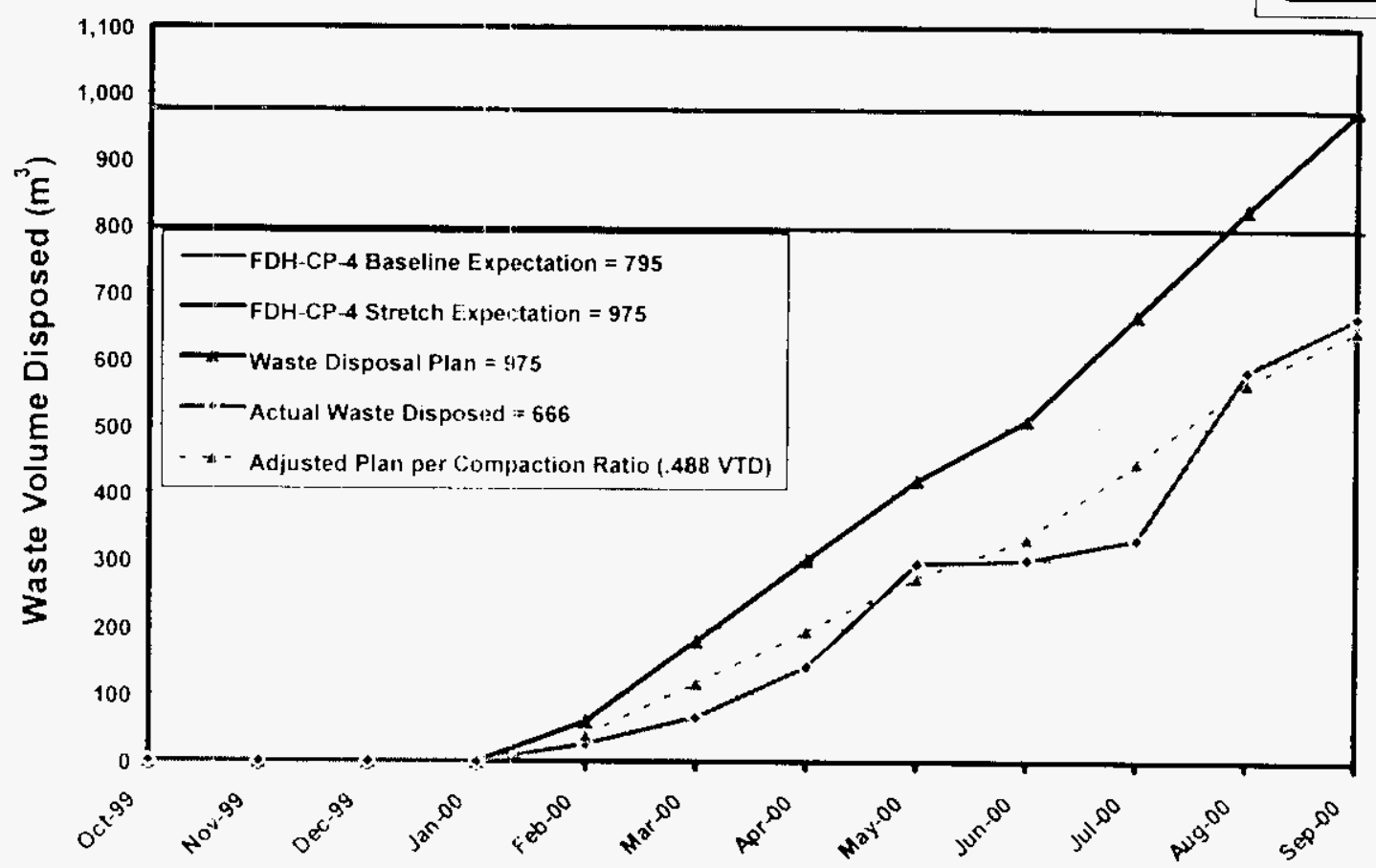

Action Plans: C'omplete. $666 \mathrm{~m}^{3}$ disposed through September 2000 (volumes adjusted for compaction ratio). 
TRU RETRIEVAL

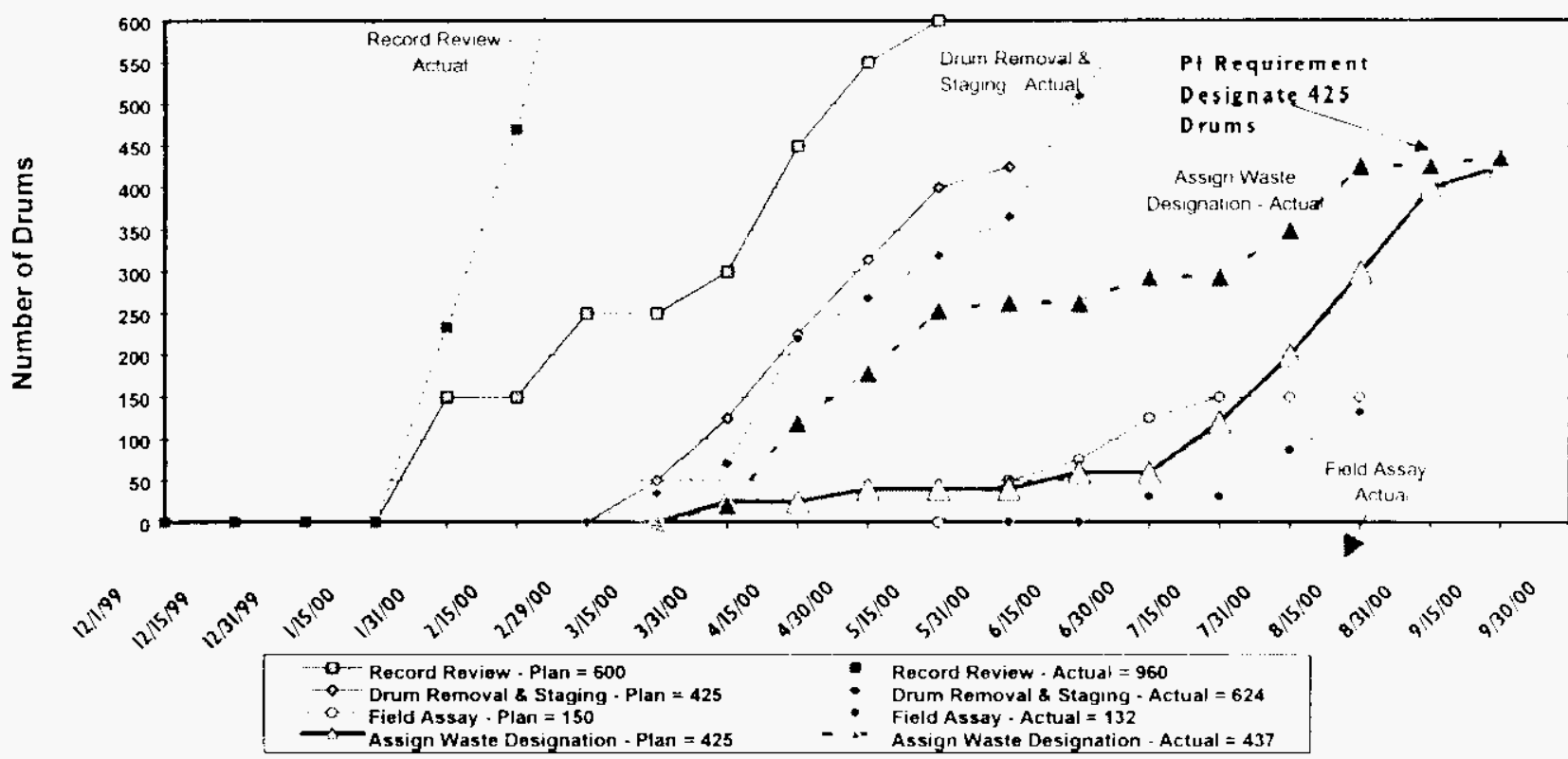

Action Plans: . omplete. 437 suspect TRU drums were designated through September 2000.

\section{tru Container Processing}

Green

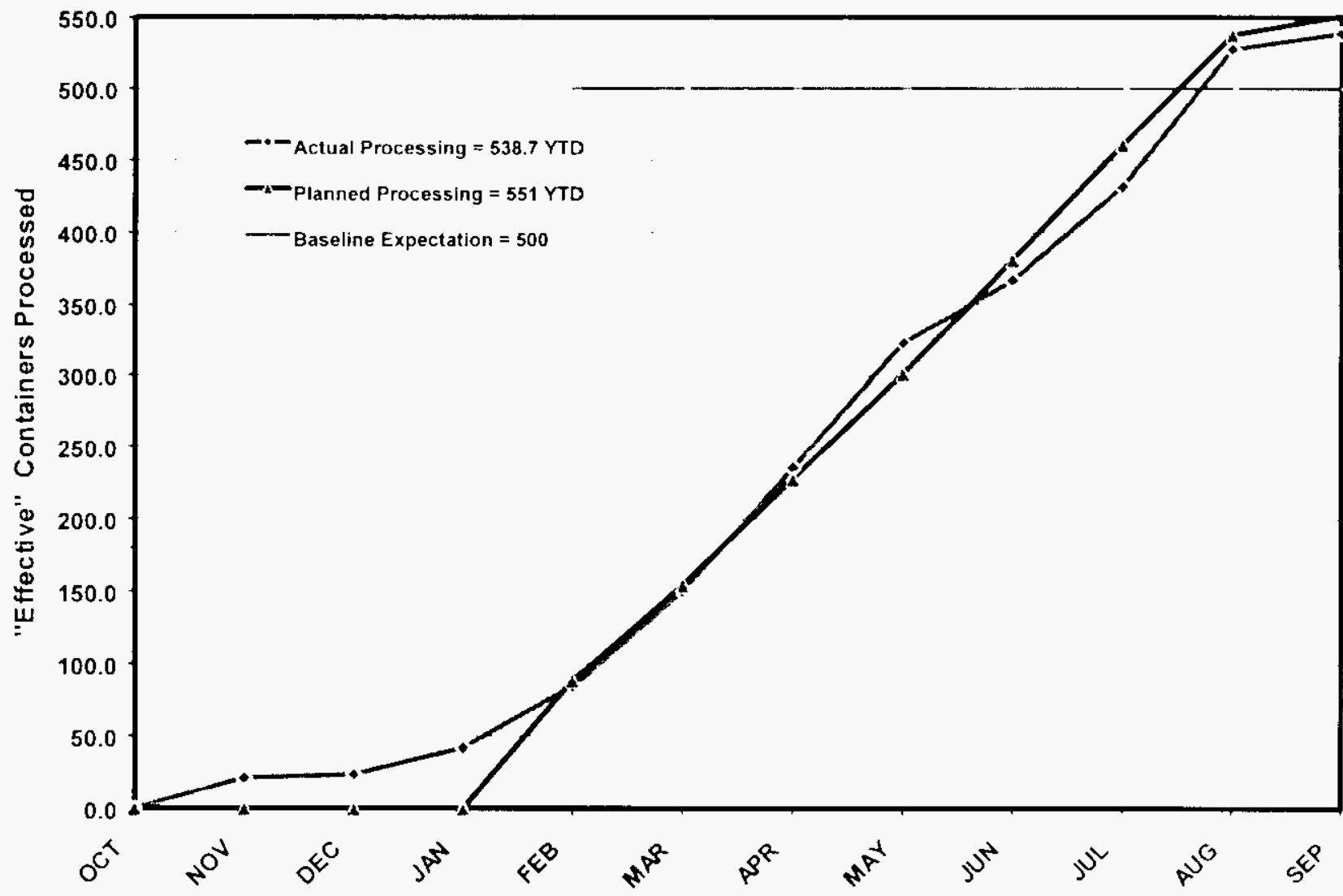

Action Plans: Complete. 538.7 "effective" containers processed through September 200()$. 


\section{TRU CERTIFICATION FOR SHIPPING}

\section{Green}

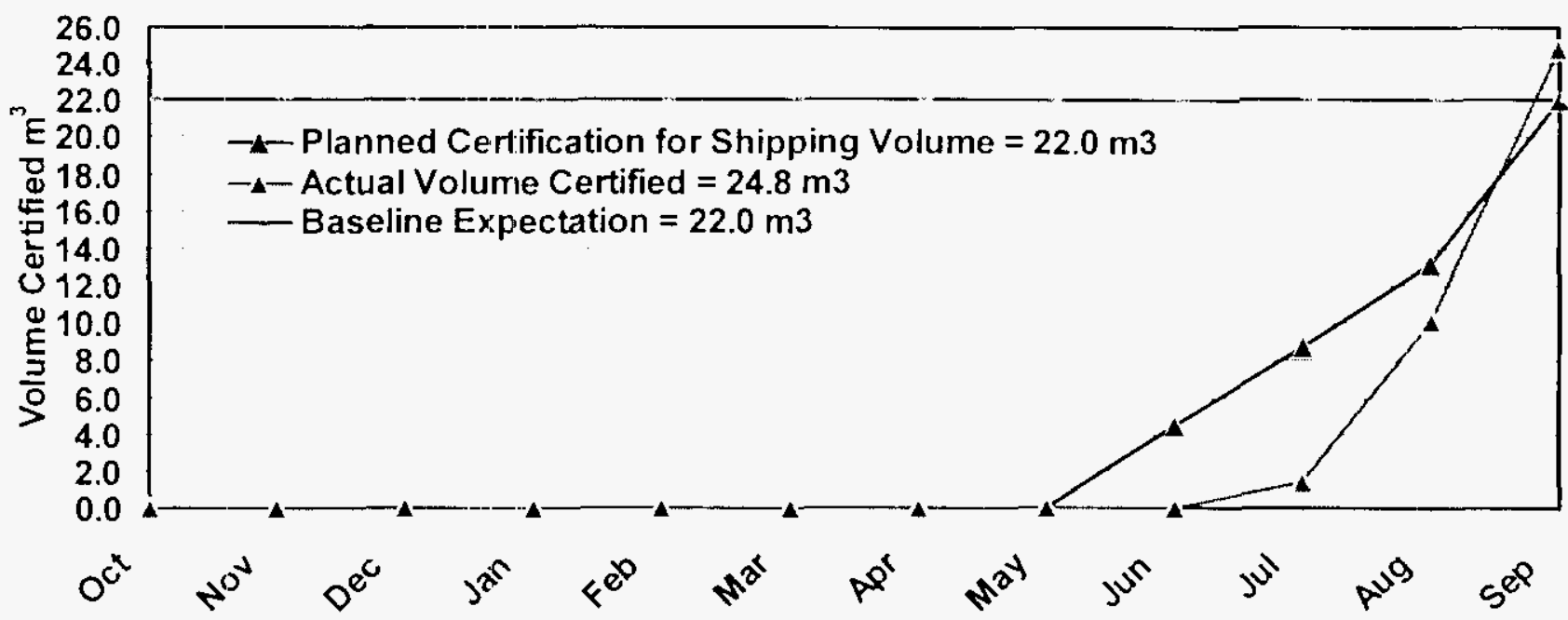

Action Plans: Complete. $24.8 \mathrm{~m}^{3}$ certified through September 2000.

\section{Liquid Waste Processing}

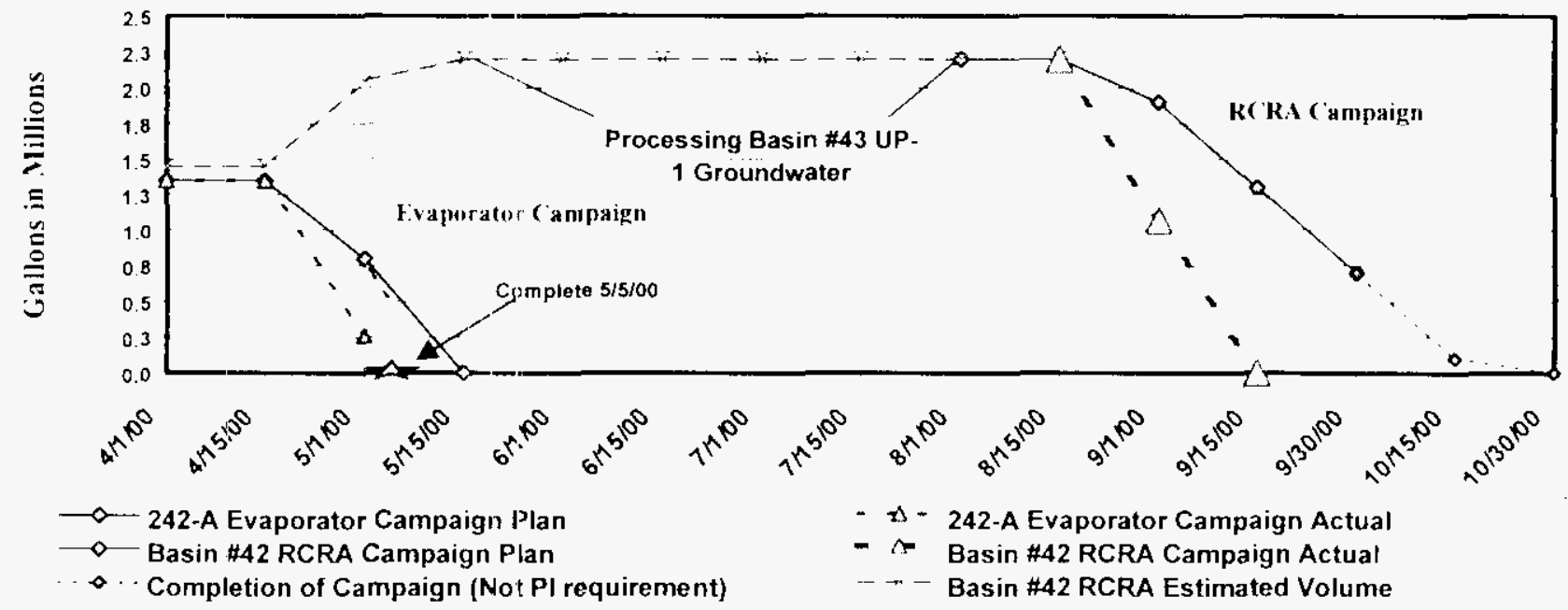

Action Plans: Complete. 'The RC'RA campaign was initiated on August 19,2000 and completed in september 2000 . Processing through September 2000 is 2.2 million gallons versus the 1.5 million gallon requirement. 


\section{T Plant Deck Clearing \\ (RC-4-1-1)}

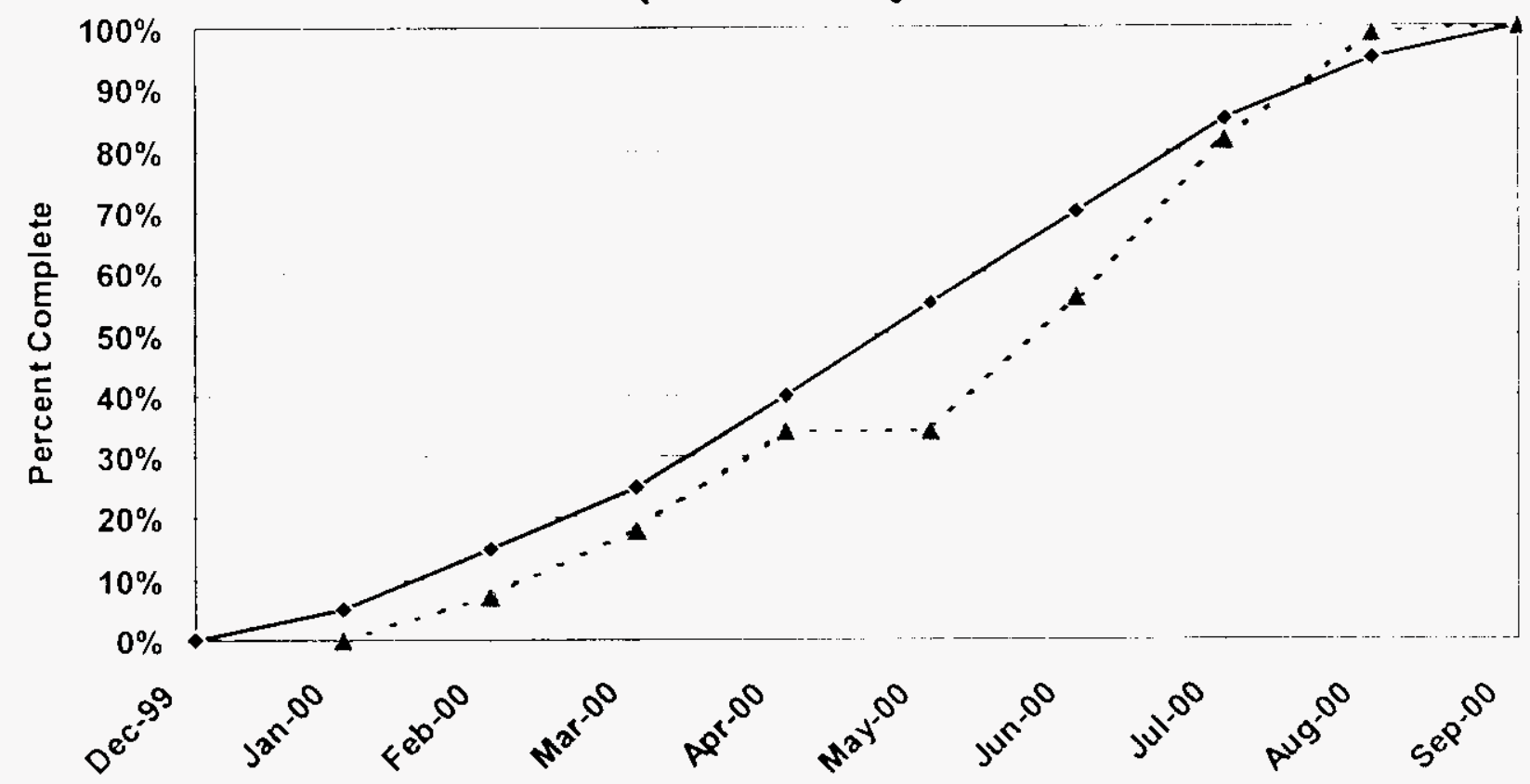

- - Planned Clear Decks - - - Actual Clear Decks

Action Plans: C'omplete.

\section{T PLANT PEP AND CDD}

\section{Green}

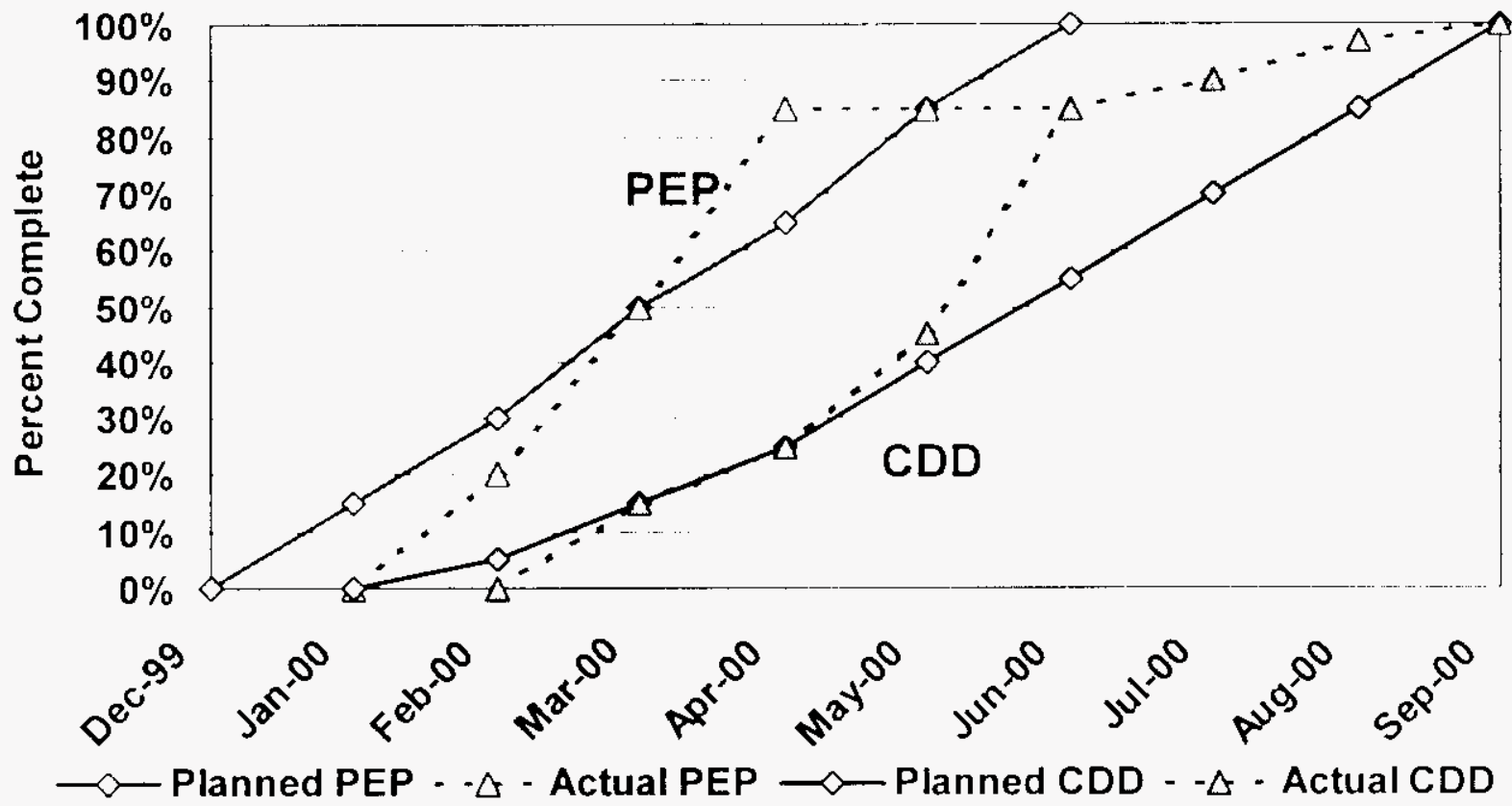

Action Plans: Complete. The Project Execution Plan (PFI'i and the Conceptual I) I)ocument (CDI)) both completed in September 2000 . 


\section{T PLANT TOWER RemOVAL (RC-4-1-2)}

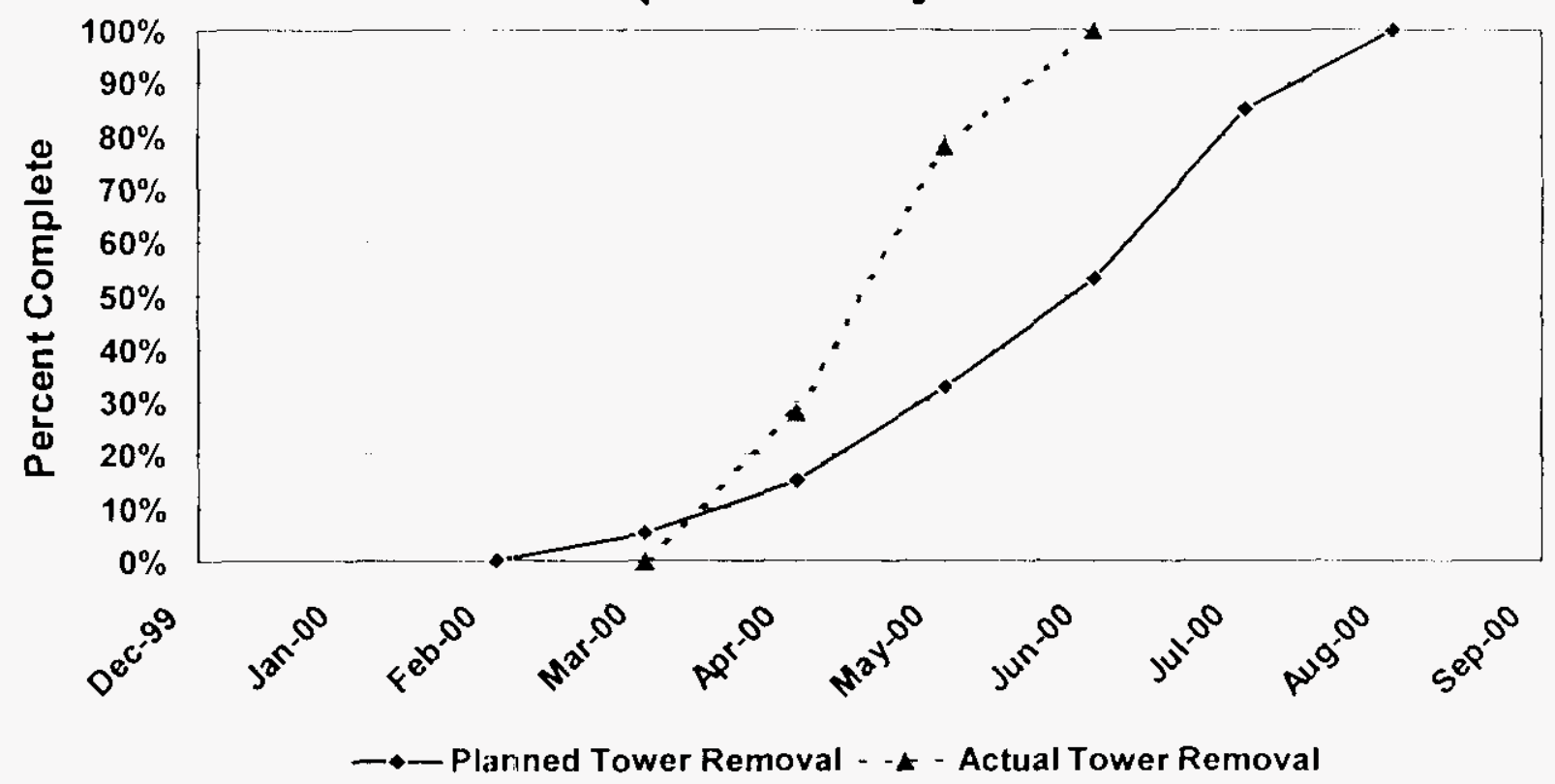

Action Plans: Complete. Two towers removed and disposed of in the low level burial grounds (LI.BG).

\section{KEY INTEGRATION ACTIVITIES}

- Preparing T Plant to receive Spent Nuclear Fuel K Basin sludge.

- Issuance of Records of Decision for Low-Level Waste (LLW) and Mixed Iow-Level Waste (MI I.W) is expected to affect Hanford's role in disposing of waste from other sites. Working with IOOE-RL, DOE-HQ and other Sites to develop and define Hanford's role as one of the identified LI,W/MLLW disposal sites for the Complex.

- Support continued UP-1 (jroundwater treatment.

- Support River Corridor Project in cleanup and removal of waste from 324 and 327 buildings.

- Support the ORP Waste Traatment Plant.

- Continue working with PNNL, LM 50 and Mixed Waste Focus Area (MWFA) to obtain lunding in support of mixed waste processing (M-91 Facility Project).

- Continue to work with DOI. RI., -Oakland, and -Ohio to support resolution of TRI small quantity site disposition issues.

- Support visits from both the DOF-Idaho Program Office and the Office of the Inspector (ieneral in regards to opportunities for treatment/disposal of Idaho National Ingineering Fnvironment laboratory (IN SIL) wastes at Hanford. 


\section{HigH LEVEL WASTE (HLW): STORAGE AND TREATMENT}

High Level Waste Store/Treatment as of September 30, 2000

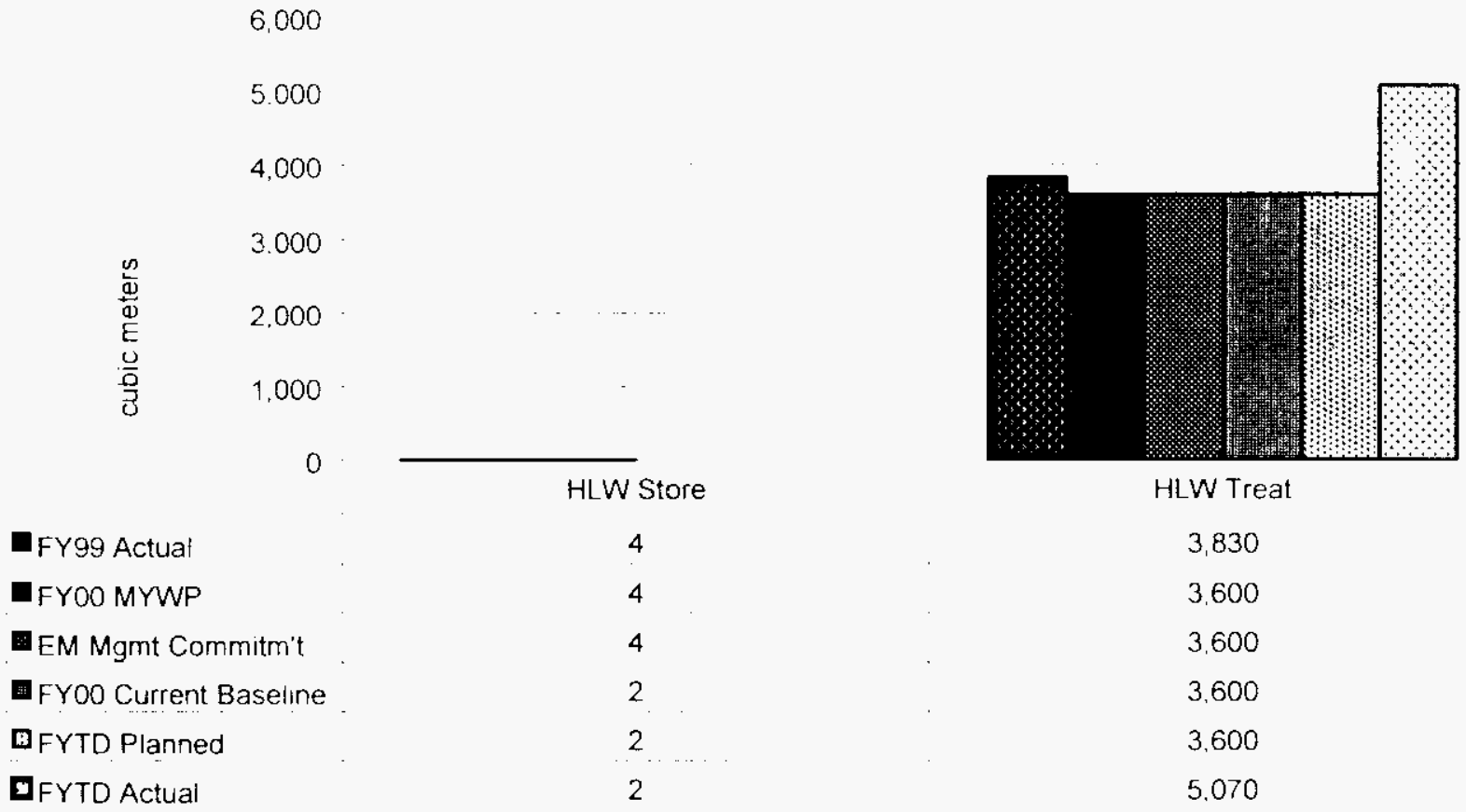

Storage: The HLW inventory of the Cesium (C's) and Strontium 90 (Sr) stored in the Wastc Encapsulation and Storage Facility (WESF) pool cells has been adjusted to provide a consistent reporting basis. The four (4) cubic meters above was based on the capsule dimensions. However, the reported HI.W inventory should have included the volume that is HI.W (i.L. the ('s and Sr salt) which is two (2) cubic meters.

Treatment: (ne evaporator campaign for treatment of high-level tank waste in FY20(0) was completed during the 3 rd quarter, treating 34 percent more than planned. Additional volume treated through the evaporator was necessary to support RPP in achieving a Performance Incentive for waste volume reduction in the Tank Farms underground storage tanks. 
PHMC Environmental Management Performance Report - November 2000

Section B: I - Waste Management

\section{TransUranic (TRU) WASTE: StORAGE, TreatMENT AND DISPOSAL}

TRansiUranic (TRU) Waste as of September 30, 2000

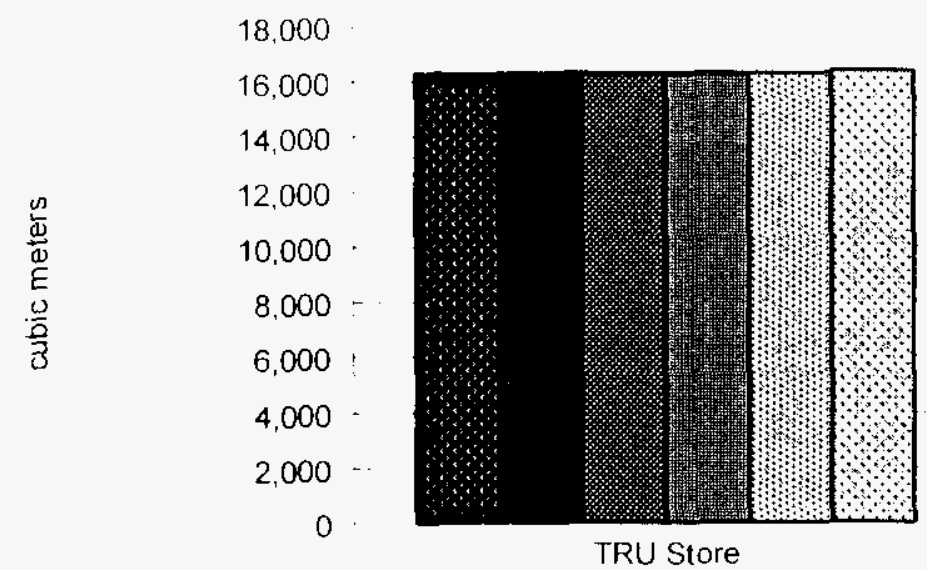

\begin{tabular}{|c|}
\hline $\begin{array}{l}\text { FY99 Actual } \\
\text { FY00 MYWF }\end{array}$ \\
\hline EM Mgmt Commitm't \\
\hline FYOO Current Baselin \\
\hline $\begin{array}{l}\boldsymbol{D}_{\text {FYTD Planned }} \\
\text { GFYTD Actual }\end{array}$ \\
\hline
\end{tabular}

16,300

TRU Dispose

16,333

0

16,333

16,316

55

16,316

55

16,407

55

19

Storage: Storage continues to be provided for existing and newly generated TRI waste. The current volume of TRU in storage is within 10 percent of the planned amount.

Treatment: Based on DOE/RL interpretation, TRU processing at WRAP does not mect the revised TRI treatment definition. Therefore. TRI treatment volumes previously identified in the FY(0) MYWP have been set to zero.

Disposal: I ess TRU was shipped to Waste lsolation Pilot Plant (WIPP) this year than planned due to delays at Carlsbad for WIPP certification for fanford waste receipts. 


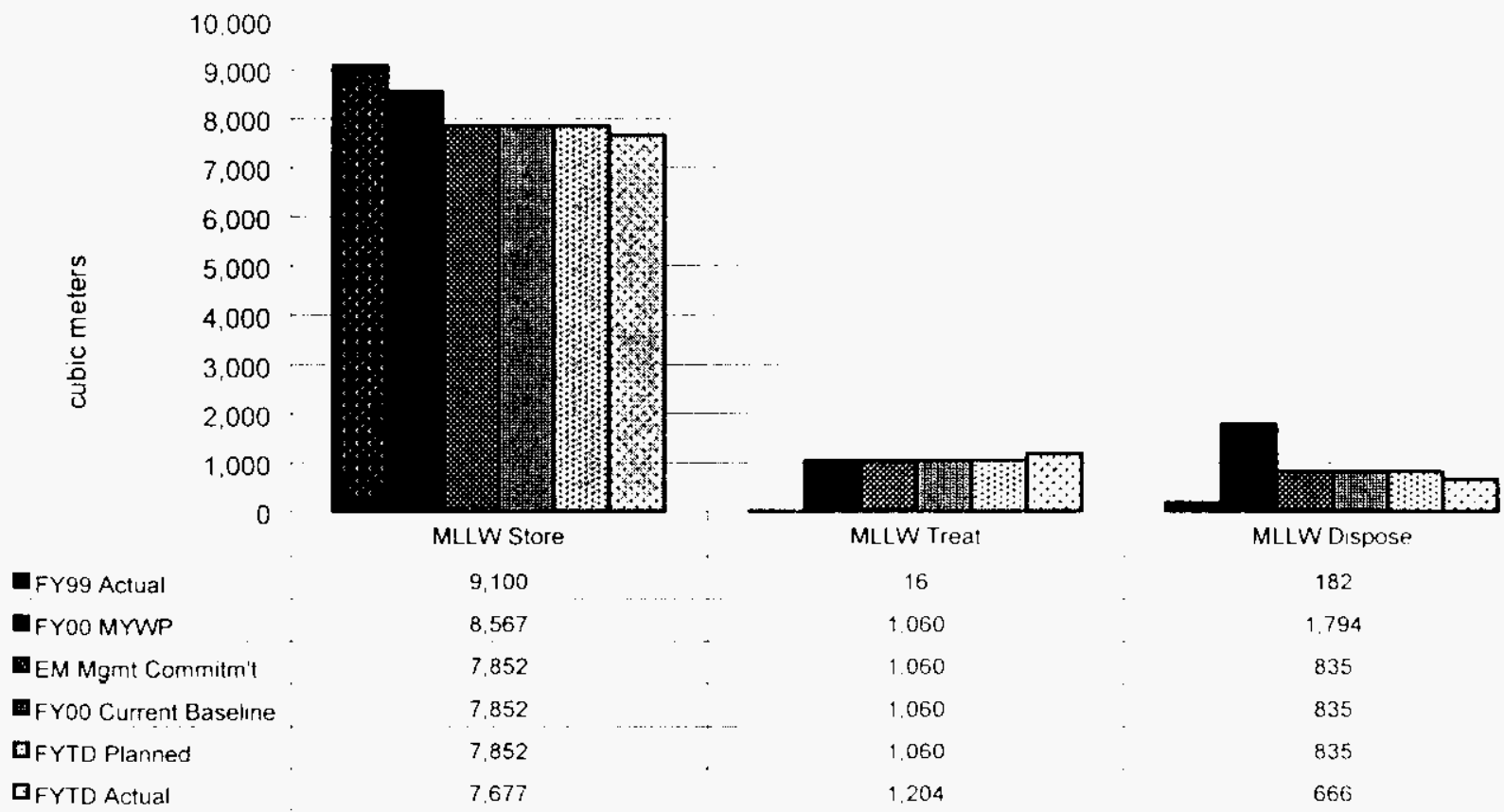

Storage: Storage continues to be provided for existing and newly generated MI.I W waste The current volume of MLLW in storage is within 10 percent of the planned amount.

Treatment: The MLLW treated exceeded the planned by approximately 13 percent. This stretch performance demonstrates increased progress towards disposition of MLI.W inventory on the site. The increased treatment volume also meets the internal RI, performance incentive for treating MILLW.

Disposal: Allied Technology Group (ATG) achieved greater volume reductions than planned (1 to .5 versus 1 to .75 ) in treating the MLLW. The current volume of treated MI.I.W. is therefore, approximately 20 pereent less than the planned volume to be disposed in $\mathrm{F} Y 2000$. 
PHMC Environmental Management Performance Report-November 2000 Section B: 1-Waste Management

\section{LOW LeVEL WASte (L.LW): StORAGE, TREATMENT, AND Disposal}

10,000 Low Level Waste as of September 30, 2000

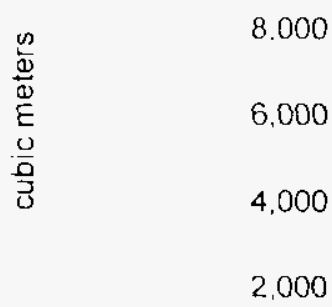

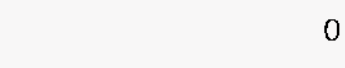

FY99 Actual

FYOO MYWP

180

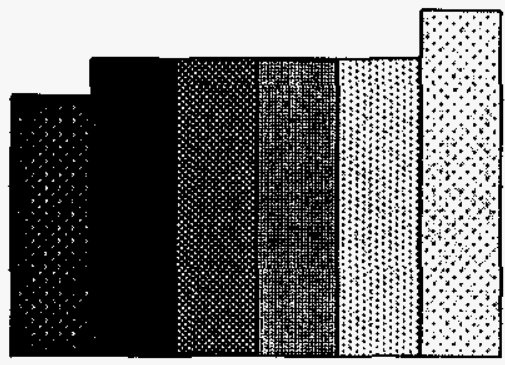

LLW Store

LLW Dispose

EM Mgmt Commitm't

180

6.080

180

6.936

m FY00 Current Baseline

180

6,936

ĐFYTD Planned

180

6,936

๑ FYTD Actual

298

6,936

8.079

Storage: An additional 118 cubic meters of JLW was placed in storage at the (central Waste Complex for certification.

Treatment: No treatment of LLW is planned until after FY2006 when a treatment alternative has been selected. Nll newly generated L.I.W receipts are prepared and packaged to the waste acceptance criteria for disposal of LLW in the burial grounds and no further treatment is required.

Disposal: C'onsiderably more: waste was received in the fourth quarter than planned resulting in 16 percent more I.I.W disposed in FY 2000. Major contributors included Parts Township. Argonne National Labs and Cieneral Atomics. 

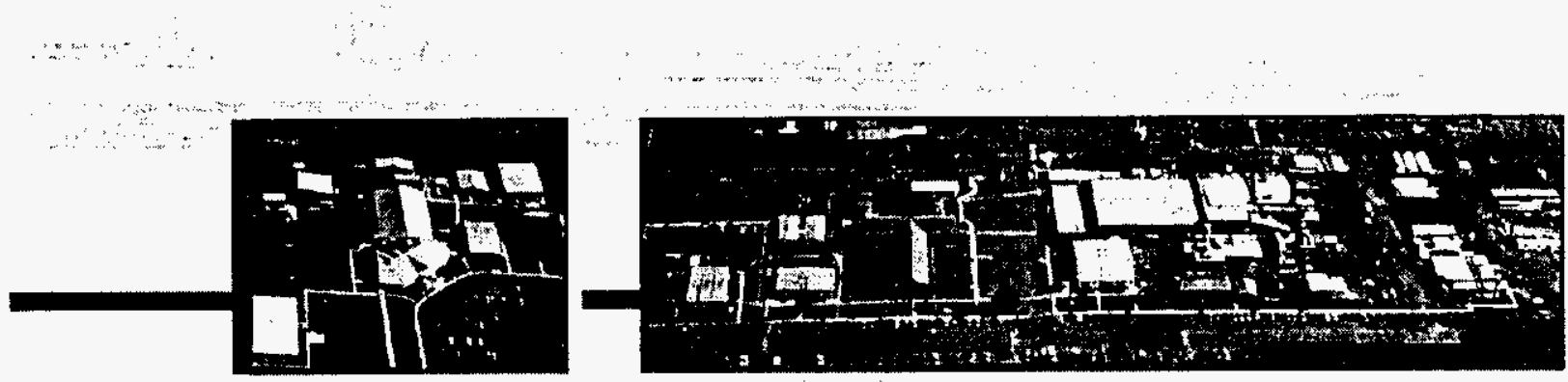

\section{Section B:2 Analytical Services (222-S, HASP, WSCF)}

PROJECT MANAGERS

S.H. Wisness, RL (509) 373-9337

D.L. Renberger, FH (509) 372-0877 


\section{SUMMARY}

The Analytical Services (AS) Project [222-S. Hanford Analytical Services Program (HASP). Waste Sampling and Characterization Facility (WSCF) / consists of Analytical Sorvices, PBSS WMO6, W'BS 1.2.4.

NOTE: Unless otherwise noted, the Safety, Conduct of Operations, Milestone Achievement, and Cost/Schedule data contained herein is as of September 30.2000). Other information is updated as noted.

\section{Top 5 Accomplishments for FY 2000}

Operations at the Waste Sampling and Characterization Facility (WSCF) exceded 2500 ) days without a lost time injury in August 2000 (Progress).

The Project completed the FY 2000 milestone commitment of 11 Analytical Fquivaleney I Init ( $\triangle \mathrm{EUS}$ ) in August, ahead of schedule. A total of $13.2 \mathrm{AL}$ Is were completed in $\mathrm{F} Y 2000$ in support of the RPP (TWRS) tank characterization program. $\wedge$ total of nine core reports. fifteen grab sample reports, and four vapor reports were issued in FY 2000. (Momentum).

All analytical reports were completed in support of $\mathrm{C} H, \mathrm{M}$ Hill Hanford Ciroup (Cll(i)

Performance Incentives affected by laboratory support. Support to development of the (Iic; Waste Treatment Plant, including providing 147 laboratory procedures and design documentation (approximately 100 drawings) of the 222-S hot cells (Momentum).

Certification of the Ilanford Transuranic (TRU) Program and waste shipments to the Waste Isolation Pilot Plant (WIPP) were supported with headspace analysis. Procedures, methods. equipment and training were significantly revised to meet the new WIPP permit from the State of New Mexico (Completion and Removal).

A total of 17,735 analyses were performed in FY 2000 at the Waste Sampling and ('haracterization Facility (WSCF) for a wide variety of eustomers as planned (Progress).

\section{Additional FY 2000 Accomplishments}

\section{Momentum}

The I)( )I:-RI, was assisted with the declaration of Readiness-to-Proceed in support of the ()RP Waste Treatment Plant Contract.

The Hanford Analytical Services Program (HASP) developed an Instrument Capital Plan for the 222-S and WSCF laboratories, based on instrument age, utilization. efficiency, and sample forecasts. A national survey on instrument utilization rates was obtained and compared to the AS laboratories.

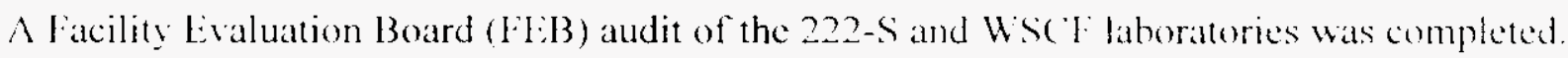


The tinal fitl 3 report was issued in february 2000 with improvements in ninc of ten areas and an overall rating of "3".

Quoting from the Defense Nuclear Safety Board Site Rep Report: "The Site Rep observed the transfer of a neutron source to the 222-S Californium Activation $A$ nalysis Facility (CAAF). The new 23 C i ( $1-252$ source is extremely radioactive (1082 rem/hr fast neutron, $93 \mathrm{rem} / \mathrm{hr}$ gamma at $30 \mathrm{~cm})$. and will be used for neutron activation of tank wastes. The neutron capsule was drawn out of a 4.5-ton transportation cask and moved through a transfer tube to an underground storage position in a dry well inside the CAAF irradiation tank. Movement was by manual crank on a continuous cable with a magnetic end effector. Several mockups and dry runs had been conducted prior to the evolution and worker involvement was significant. This planning resulted in a good pre-job bricf and a smooth transfer."

Fcology inspected the 222-S I aboratory in August 2000 with the intent to closcout the 222-S Settlement $A$ greement. The agreement expired in June 2000 but states that Ecology will issue a letter vacating the fine. Ecology was satisfied that we had a system and could identify the controls necessary to adequately manage our waste. The State of Washington Pollution Control Hearing Board issued a letter closing the issue on August 24, 2000.

Analytical Services won awards for booth displays in two categories, "Most Interactive" and Kid's Favorite" at the Health and Safety Expo 2000.

\section{Completion and Removal}

The successful completion of the 242A Evaporator campaign, including expedited feed tank analysis for ORP was supported

Fiscal-year-to-date-milestone performance (EA, I)OF-HUQ and RI.) shows one milestone completed ahead of schedule.

\section{Accomplishments this Reporting Period}

- Processed a total of $1.4 \mathrm{AFEl}$ ls at the 222-S laboratory in September in support of the RPP (IWRS) tank characterization program and issued cight characterization reports in support of RPl'.

- Performed 1.128 analyses in September at WSC For a wide variety of customers as planned. Through ()etober 23, 2000, production for FY 2001 is 800 analyses.

- Hosted the executive director (1)r. (ihassemi) of the Waste Management leducation and Rescarch ('onsortium (WI:RC) on Oetober 3-4, 2000). (opportunities to leverage WI:RC expertise and experience in environmental education, technology development and outreach were explored in meetings with RL, the contractors, and with universities and community colleges. RL is very pleased it the progress to date and supports continued efforts with WIERC at lanford. 


\section{SAFETY}

In September, there were 2 OSHA recordable cases, no Restricted Workday ('ases. and four lirst Aid Cases. The (OSHA recordable case rate is increasing. with 2 of the past 3 months at two standard deviations above average, and the DOE Safety ('ost Index has been rebaselined upwards due to recent increasing trends. Analytical Services continues to focus on ergonomic issues, and has brought HEHF expertise to 222-S to assist in ergenomic evaluations.

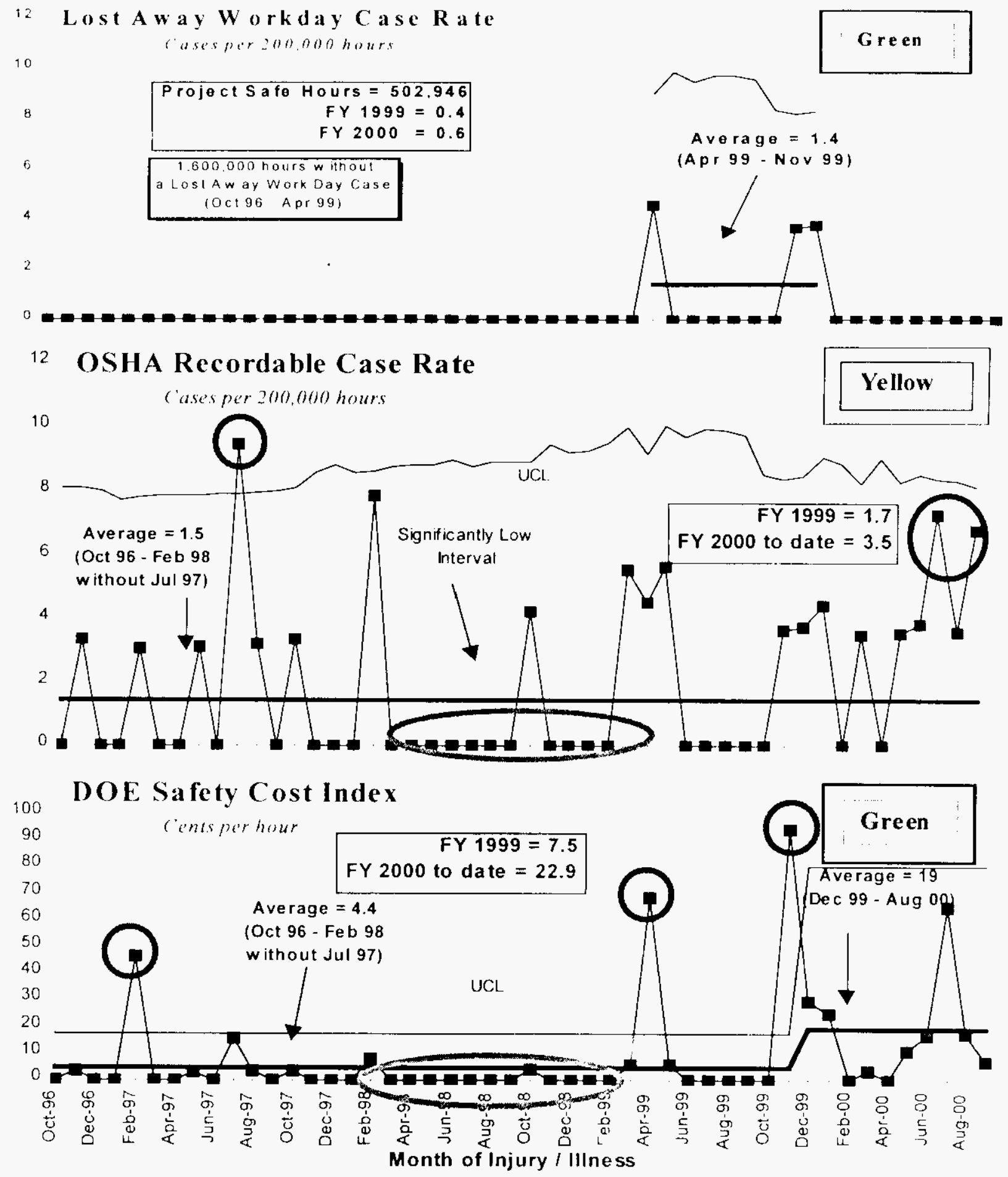




\section{CONDUCT OF OPERATIONS / ISMS STATUS}

Conduct of Operations Index

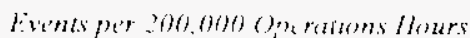

\section{Green}

60

50

40

$$
\text { Avg }=9.1
$$

(Apr 96 - Dec 96)

30

20

10

0

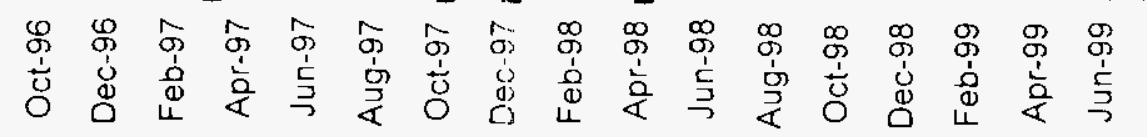

Number of Reports Past 12 Months

2

4

6

8

10

12

14

16

18

20

Personnel Contamnation

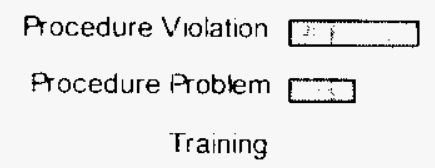

Management Problem

Lock and Tag $\square$

Work Control

\section{ISMS STATUS}

Analytical Services ISMS status is included in the Waste Management

Green

\section{BREAKTHROUGHS}

Nothing to report at this time.

\section{OPPORTUNITIES FOR IMPROVEMENT}

\section{Green}

Analytical Services Facility and Equipment Upgrades Team: RI, is assessing the framework under which cleanup can be maximized while working to incorporate a "realistic" funding profile over the next ten to fifteen years. Consistent with the RL outcomes, the priority is achieving the River Corridor Outcome by 2010 or shortly thereafter. This approach necessitates a probable resequencing of the current baseline activities in the 200 Areas. An Analytical Services Facility and Iquipment Ipgrades Team have identified required facility and equipment work scope to 
support the RI, outcomes. Presentations were made to Fll and RI. Lo detail rishs and impacts associated with the work scope to the Site cleanup mission Related activities:

A long-term laboratory instrument capital plan. including analytical reliability requirements, was: prepared in response to concerns over the lack of adequate funding in $\mathrm{FY}(0)$ and future years for Capital equipment not related to construction (CERTC), facility repair and I aboratory Information Management System (LIMS) upgrades. RPP recognizes the need and is indicating a willingness to fund a portion of the upgrades needed to provide ar relability of analytical services.

Analytical Services provided input to a DOE-HQ Infrastructure Restoration Plan to incorporate long-term Ilanfird laboratory needs.

\section{UPCOMING ACTIVITIES}

WIPP Waste Shipments - Continue to support the production goal of headspace analysis in support of waste shipments to WIPP.

ORP Waste Treatment Plant - A recommendation from the 200 Areas Option Study is to determine Analytical Services support requirements to the ORP Waste Treatment Plant. Ihis includes technical support to the WTP design, cold testing and startup support, process control and monitoring, and troubleshooting. Options for long-term high-activity laboratory support to the Site cleanup mission (i.e. 222-S. WTP laboratory. a new laboratory, etc.) are also to be evaluated. These potential areas of support to the ORP WTP' were compiled and submitted to RI.

222-S RCRA Part B Application - Issue Modification F (222-S) of the Hanford Facility (IIf) RCRA Permit for public review after issuance of Modificat on $\mathrm{I}$. Ecology is planning on issuing Modification I: (WRAP and CWC) by the end of the calendar year. Prepare and deliver the remaining permit application items (Dangerous Waste 'Training Plan and the updated WII)S input) to licology, after issuance of Modification I:

PCB Management - Continue to work with RI and ORP on PC'B management and regulatory issues.

Bioassay, Analytical, and Fnvironmental Radiochemistry (BAER) (onference D)r. Steven Bakhtiar of Analytical Services is chairing the $46^{\text {th }}$ Annual BAB:R conference in Siattle in mid-November 2000 . 
PHMC Environmental Management Performance Report-November 2000

Section B: 2 - Analytical Services (222-S, HASP, WSCF)

\section{Cost Performance $(\$ M):$}

\begin{tabular}{|l|c|c|c|}
\hline & BCWP & ACWP & VARIANCE \\
\hline Analytical Services & $\$ 27.6$ & $\$ 26.5$ & $\$ 1.1$ \\
\hline
\end{tabular}

The $\$ 1.1$ million (4 percent) falvorable cost variance is within established thresholds.

\section{SCHedule Performance ( $\$ M)$ :}

\begin{tabular}{|l|c|c|c|}
\hline & BCWP & BCWS & VARIANCE \\
\hline Analytical Services & $\$ 27.6$ & $\$ 28.3$ & $-\$ 0.7$ \\
\hline
\end{tabular}

The $\$ 0.7$ million (2 percent) unfavorable schedule variance is within the established threshold.

\section{FY 2000 Cost/Schedule Performance - All Fund Types Cumulative to Date Status - $(\$ 000)$}

FYTD

\section{Green}

By PBS

WBS 1.2.4 Analytical

\begin{tabular}{lllllll}
\hline BCWS & BCWP & ACWP & SV & $\%$ & CV & $\%$
\end{tabular}

PBSWMO6 Services

\begin{tabular}{lllllllll}
$\$ 28,334$ & $\$ 27.626$ & $\$ 26.524$ & $\$(708)$ & $-2 \%$ & $\$$ & 1.101 & $4 \%$ \\
\hline$\$ 28.334$ & $\$ 27.626$ & $\$ 26.524$ & $\$(708)$ & $-2 \%$ & $\$$ & 1,101 & $4 \%$
\end{tabular}

Note: RI.-I)irected costs (stean and laundry) are included in the Pl:M BCWS/AC 'WP/L $\triangle$ (.. 


\section{Cost/Schedule Performance INDices (MONTHLY AND FYTD)}

\section{Green}

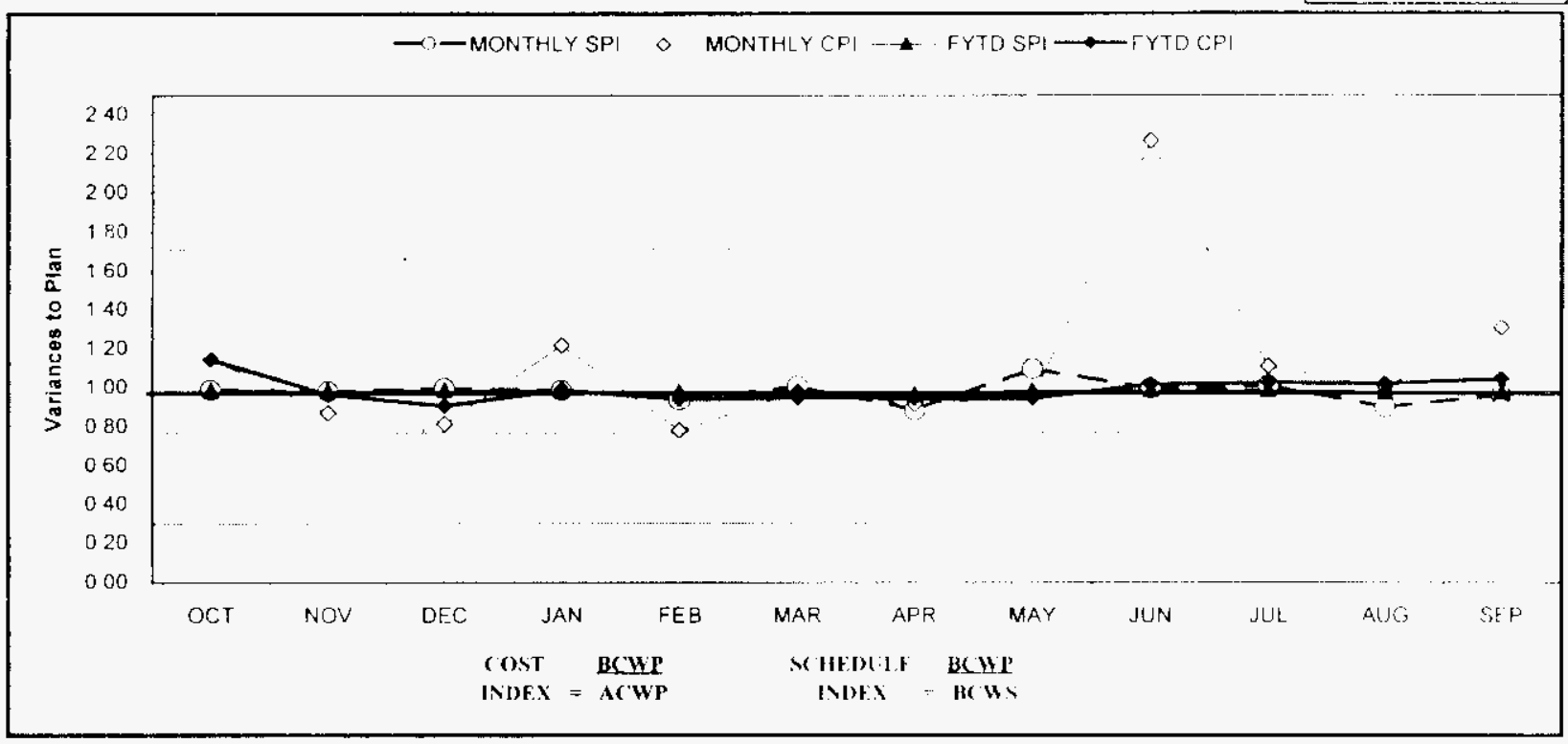

\begin{tabular}{|c|c|c|c|c|c|c|c|c|c|c|c|c|}
\hline FY 2000 & $O C \mathrm{I}$ & Vol & DEC & JAN & FE.B & $M A K$ & If'K & IAI & JIX & $\mathrm{JI}$ & 111, & StP' \\
\hline MoNiHI.Y.SPI & 090 & $09 \mathrm{~K}$ & 099 & 098 & 094 & $i(k i)$ & 1188 & $1(14)$ & $1)^{(x)}$ & 101 & $1 ;(x)$ & (1) \\
\hline .16 NiHI.Y & 114 & 087 & 0.81 & 1.22 & (1) 78 & 1198 & $(!) !$ & (1) 4.4 & $\therefore 21$ & 111 & $1+1+1$ & 131 \\
\hline IYTIDSI & 1190 & 048 & (1) 99 & (1) 98 & 0.97 & i) 128 & (1)? & 098 & $(1) \times$ & (1) $6 x_{3}$ & $119 x$ & $11 \div 8$ \\
\hline I) & 114 & (1) $1 \%$ & 691 & 690 & 1) 94 & 1194 & (1) 64 & 0194 & 1191 & $10:$ & I11.' & 101.4 \\
\hline 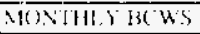 & $51.58 \mathrm{BX}$ & $52,3.40$ & $\$ 1.973$ & $\$ 2.8 \%$ & $\$ 2,283$ & $\$ 2413$ & 82.270 & 52.358 & 52.420 & 3246,13 & $8: 5 x$ & $8285=$ \\
\hline MoNIll. $336 \mathrm{WP}$ & $\$ 1.500$ & $\$ 2.288$ & $\$ 1.960$ & $\$ 2.848$ & $\$ 2.135$ & $82.6 ! 14$ & 8.2 .110 & 53578 & $\$ 247:$ & $\$ ? 080$ & $\$ 2,3 ? 1\}$ & 827 \\
\hline MoNIHIS ACWP & $51.3(10)$ & $\$ 2,640$ & 52.414 & $\$ 2.342$ & $\$ 2,741$ & $\$ 2.6811$ & $\$ 2.208$ & 52.733 & $\$ 1.19 ?$ & $\$ 1.88^{\circ}$ & 52319 & $8 ? .09 !$ \\
\hline$! Y ! 1) 13(\mathrm{~B} \leq$ & $\$ 1.588$ & 53.928 & $\$ 59(1)$ & $\$ 8.797$ & $\$ 11,080$ & $51.30+23.3$ & $51<473$ & 518.330 & 5.6923 & $5228 \% 2$ & 826481 & $52 k 34$ \\
\hline (YII) A( 'Wl & $\$ 1.369$ & $\$ 4(10 \%)$ & $\$ 6.423$ & $\$ 8.765$ & 511.506 & 514.143 & $5]+4(1)$ & 519.134 & 5201.228 & $822.11 i$ & 5.1 .7 .1 & 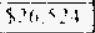 \\
\hline
\end{tabular}

\section{COST VARIANCE ANALYSIS: ( $\$ 1.1 \mathrm{M})$}

\section{$\underline{\text { WBS/PBS }}$}

1.2.4/WMO6

Description/C ausc: The favorable cost variance of

thresholds.

Impact: None.

Corrective Action: None required.

\section{SCHEDUle VARIANCE ANALYSIS: (-\$0.7M)}

\section{$\underline{\text { WBS/PBS }}$}

1.2.4/WMO6

established threshold.

Impact: None.

Corrective Action: None required.

DOE/RL-99-83, Rev. 10
Title

Analytical Services 
PHMC Environmental Management Performance Report - November 2000

Section B: 2 - Analytical Services (222-S, HASP, WSCF)

\section{FUNDS MANAGEMENT \\ FUNDS VS SPENDING FORECAST $(\$ 000)$ \\ FY TO DATE THROUGH SEPTEMBER 2000 \\ (FLUOR HANFORD, INC. ONLY)}

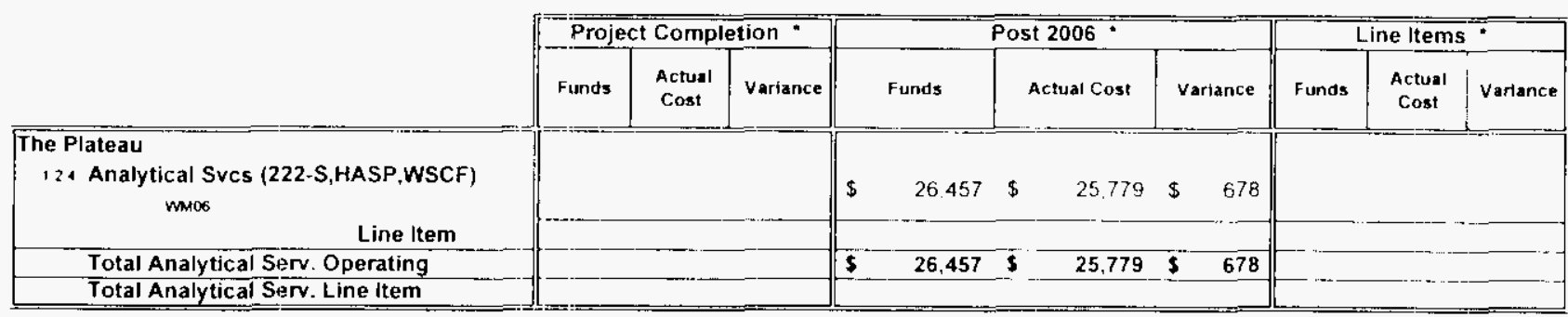

- Control Point

\section{Technical Issues}

ISSUES

Nothing to report at this time.

\section{DOE/Regulator/External Issues}

Nothing to report at this time.

\section{Baseline Change Requests Currently in Process (\$000)}

\begin{tabular}{|c|c|c|c|c|c|c|c|c|c|}
\hline $\begin{array}{l}\text { PROJKCT } \\
\text { CHANCE } \\
\text { YNHFR }\end{array}$ & $\begin{array}{l}\text { DATE: } \\
\text { ORIGIS. }\end{array}$ & HCR HTLE: & 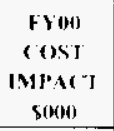 & \begin{tabular}{l|}
$s$ \\
$\mathrm{c}$ \\
$\mathrm{H}$
\end{tabular} & \begin{tabular}{l|l}
1 \\
$\mathrm{~F}$ \\
$\mathrm{i}$ \\
$\mathrm{H}$
\end{tabular} & $\begin{array}{c}\text { DATE TO } \\
\text { (re }\end{array}$ & $\begin{array}{c}(\mathrm{CH} \\
\mathrm{APH} \times \mathrm{V})\end{array}$ & RI. APR'YD & $\begin{array}{l}\text { CIRRENT } \\
\text { SINTIS }\end{array}$ \\
\hline $\begin{array}{l}{[11-2001-000]} \\
1 \cdot 11-200) 1-002\end{array}$ & $\begin{array}{l}0 / 12 / 00 \\
0 / 25 / 00\end{array}$ & 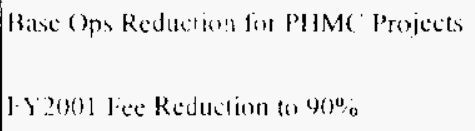 & $\begin{array}{l}-\$ 6100 \\
-\$ 190\end{array}$ & & $x$ & & & & $\begin{array}{l}\text { I rasti Prepared } \\
\text { Dratt Prepared }\end{array}$ \\
\hline \multicolumn{10}{|c|}{ IDANC WORK Al!HORI/ATIONS } \\
\hline & & Nothing to regur a this tome. & & & & & & & \\
\hline
\end{tabular}


PHMC Environmental Management Performance Report - November 2000

Section B: 2 - Analytical Services (222-S, HASP, WSCF)

Milestone AChievement

\section{Green}

\begin{tabular}{|c|c|c|c|c|c|c|c|c|}
\hline \multirow[b]{2}{*}{ MLESTONE TYPE } & \multicolumn{4}{|c|}{ FISCAL YEAR-IO-I)AII: } & \multicolumn{3}{|c|}{ RIMAININ(iSCHFI)I I I I) } & \multirow[b]{2}{*}{$\begin{array}{l}\text { TOTAL, } \\
\text { FY } 2000\end{array}$} \\
\hline & $\begin{array}{c}\text { Completed } \\
\text { liarly }\end{array}$ & $\begin{array}{c}\text { Completed } \\
\text { On } \\
\text { Schedule }\end{array}$ & $\begin{array}{l}\text { Completed } \\
\text { late }\end{array}$ & (Bucralu & $\begin{array}{c}\text { Forccist } \\
\text { Irarls }\end{array}$ & $\begin{array}{c}\text { forceast } \\
\text { (1n } \\
\text { Schedule }\end{array}$ & $\begin{array}{l}\text { Forecist } \\
\text { I.a1c }\end{array}$ & \\
\hline Fnforceahle Agrement & 0 & 0 & ()) & (1) & (1) & 0 & 11 & () \\
\hline $\begin{aligned} \mathrm{DOF}-\mathrm{HO} \\
\end{aligned}$ & 0 & 0 & (1) & 0 & () & (1) & if & 0 \\
\hline 10 & () & 0 & (1) & (1) & () & i) & (1) & 0 \\
\hline RI. & 1 & 0 & 0 & 0 & (1) & (1) & 0 & 1 \\
\hline Total Project & 1 & 0 & 0) & 0 & 0 & 0 & 1) & 1 \\
\hline
\end{tabular}

\section{Tri-Party Agreement / EA Milestones}

Nothing to report at this time

DNFSB Commitments

Nothing to report at this time.

\section{MILESTONE EXCEPTION REPORT}

Number/NBS Level

Milestone Title

Baseline

Forecast

Date

Date

\section{OVERDUE - 0}

FORECAST LATE - 0 


\section{Performance Objectives}

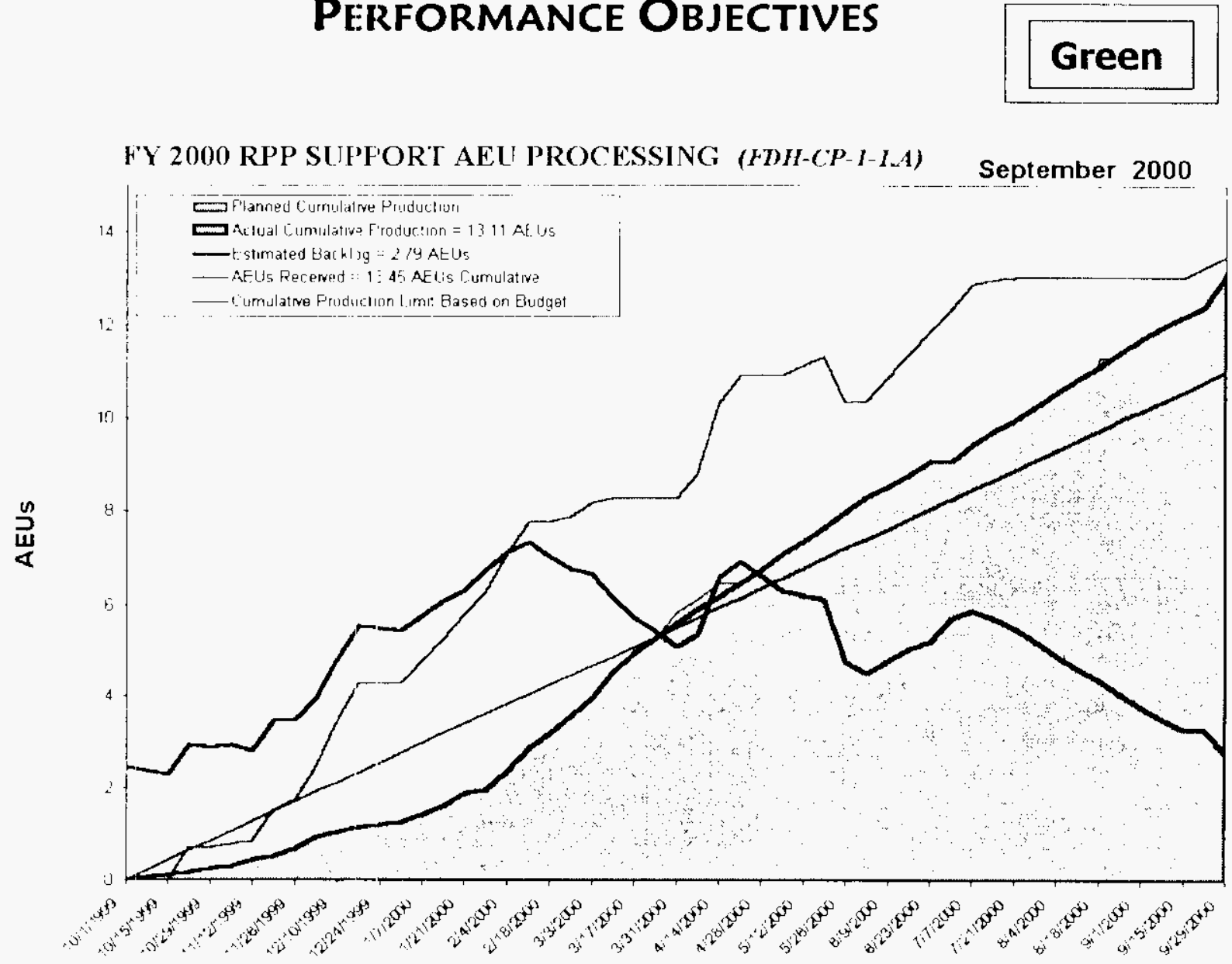

Completed the FY 2000 milestone of 11 AlUS on August 18, 2000. ahead of the September 30. 2000 date. Production through September 2000 is 13.1 ALL is, versus a planned $10 \mathrm{Al}$ ils Production for the month of September was 1.4 Alius.

\section{KEY INTEGRATION ACTIVITIES}

- Continue to support ORP offorts to establish required analytical support for Waste Treatment Plant (WTP) design and opreration.

- Continue to support Waste Management headspace gas analyses for TRI waste shipment to WIPP. 

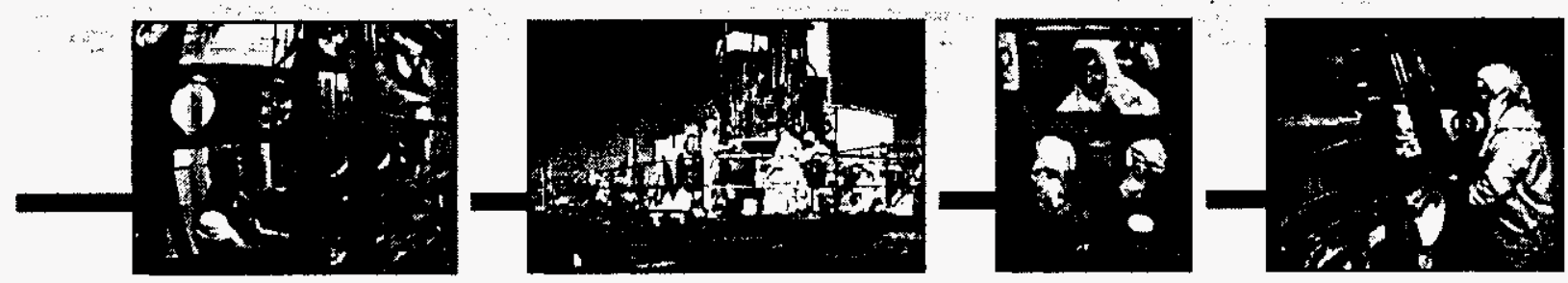

\section{Section C:1 Nuclear Material Stabilization}

PROJECT MANAGERS

P.M. Knollmeyer, RL (509) 376-7435

G.W. Jackson, FH (509) 373-6622 


\section{SUMMARY}

The Nuclear Material Stabilization mission consists of the Plutonium Finishing Plant (PIT). WBS 1.4.5 and 1.4.6.1. (PBS TP05 \& TP12)

NOTF: Unless otherwise noted, the Safety, Conduct of Operations, Milestone Achievement, and Cost/Schedule data contained herein is as of September 30, 2000. All other information is as al October 9,2000 unless otherwise stated.

\section{Top 5 Accomplishments for FY 2000}

The NMS has worked over 1.000,000 safe hours since the last lost time injury, equivalent to 323 days, since the last workday injury in December 1999 (Progress).

Process improvements and installation of three additional muffle furnaces in March 2000 resulted in the thermal stabilization of more than 650 plutonium-bearing items during $\mathrm{l}: \mathrm{Y} 20(0)(0$. Additionally, emergent safety concerns led to the oxidation or repackaging of thirteen (13) additional "higher risk" metal items. This year"s results represent a four-fold increatse over last year's production level. Additionally, limited off-site shipment of stabilized material has heen initiated (Progress).

The accelerated startup of the residue packaging process in September, initially packaging imported Rocky Flats ash, was accomplished through successful negotiations between the Department of Energy, Fluor Hanford Inc., and the Washington State Department of licology. This resulted in a Tri-Party Agreement that established: 1) an interim Tri-Party Agreement milestone for an April 30, 2001 completion of Rocky Flats ash packaging; and 2) authorized temporary storage of packaged ash in the PFP. Packaged residue materials are scheduled for future shipment to the Waste Isolation Pilot Plant (WIPP) in New Mexico (Progress).

The startup operation of the magnesium hydroxide precipitation process, initiated in September. is converting potentially volatile plutonium nitrate acid solutions to a stable oxide form thereby reducing a significant safety risk. The PFP's accredited Integrated Environment. Satety and Health Management System (ISMS) was an integral factor in the system design that optimized efficiency and safety through employee involvement (Progress).

Operation of an automated state-of-the-art system known as the Bagless Transfer System (BIS) began September 30, 2000, at the PFP. This system. designed and fabricated by Westinghouse Savannah River Company, accelerates packaging capabilities and reduces radiation expersure through automated packaging of plutonium-bearing material in welded stainless steel containers (I)partment of Energy Standard, DOE-STD-3013-99) for long term storage. The outer container packaging welder system is scheduled for operation in spring of 2001 , providing the complete DOE-STD-3013-99 packaging capability. A second inner container packaging system. currenty scheduled for operation in late summer of 2001 , will double the thermal stabilization capability and eliminate " building to building" material transfers (Progress). 


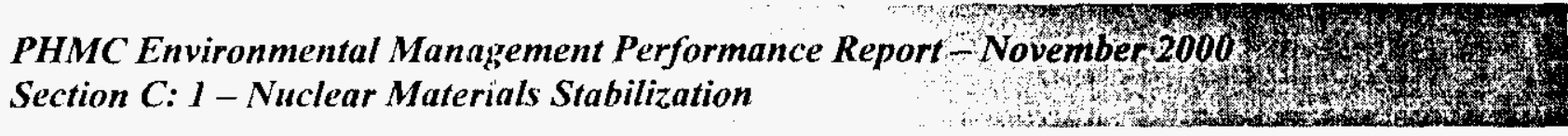

\section{Additional FY 2000 Accomplishments}

\section{Progress}

The Defense Nuclear Facilities Safety Board (DNFSB) noted substantial improvements in the PFP criticality safety program. Areas of improvement include independent assessment and oversight, training, and better contractor ownership with strong formal self-assessments.

The Facility Evaluation Board (FEB) conducted an annual assessment of the PFP and concluded that overall plant performance has improved during the past 2 years. Areas making significant progress include radiation protection, OSH LA, emergency management, and engineering.

Fiscal-year-to-date milestone performance (EA, DOE-HQ, and RL) shows that seven of thirteen milestones ( 54 percent) were completed on or ahead of schedule, four (3l percent) were completed late, and two ( 15 pereent) are overdue. Further details can be found in the milestone exception report following the cost and schedule variance analysis.

\section{ACCOMPLishments this Reporting PeRIOD}

\section{Maintain Safe and Compliant PFP}

- Through Oetober 18,200(1, there have been more than $1,000,000$ hours, equivalent to 323 days, since the last workday injury in December 1999.

- Installation and testing of backflow preventers within the Plutonium Finishing Plant (PFP) continued. (urrently back flow preventers have been installed, tested, and are operating on fire risers $\# 5$. \#6, $\# 8$, and $\$ 9$. This FY 2001 milestone activity (TRP-(01-511) remains on schedule to a June 2001 completion.

\section{Oxides/Metals/Polycubes Stabilization}

- Thermally stabilized over 135 items during September contributing to the thermal stabilization of more than 650 plutonium-bearing items during FY 2000.

- Thermal Stabilization suecessfully opened, brushed, and transferred two metal items to the B TS for placement into it welded can and return to vault storage.

Stabilization of one item and transfer out using a BTS can was one of the stretch goals for PFP.

- Milestone TRP-00-503. "('omplete Air Operating Permit/Environmental Protection Agency (AOP/EPA) review for alloy processing and issue the Notice of Construction by September 30. 20(0)", was completed September 26. The mufle furnace Notice of Construction (NOC) has been revised and was approved by the Washington State Iepartment of Ilealth. This $N O$ ( includes brushing and repackaging as a stabilization process that may be used for metals and alloys. A new scurce review applicability evaluation was completed which showed submittal to the Washington State Department of Ecology was not required.

\section{Residue Stabilization}

- Startup of the Pipe-n-(Go process was achieved September 11, 2000. This milestone effort was preceded by discussions between Rl. Fll and the Washington State Department of 
lacology (licology), that established 1) an interim Iri-l'arty Agreement milestone for an April 30.2001 completion of Rocky Flats ash packaging. and 2) authorized temporary storage of packaged ash in the PIP.

\section{Solutions Stabilization}

- Completed DOE (ORR.

- DOE authorization to begin operation received on September 18.2000

- Initiated Phase 1 of the Startup Plan. Start Hot Runs, on September 20. 2000

- Conducted hot runs through October 5, 2000 (includes extension due to Site Fire)

- Met the threshold amount identified in the Performance Incentive. to allow earning stretch fee

- Supplement Analysis to the Environmental Impact Statement (IIS) approved by the RI Manager

- Revision to the NOC was approved, permitting processing of solutions up to a molarity of five

\section{Safe and Secure SNM}

- Finaliza. NI)A confirmatory measurements of five ash standards for Pipe-n-(io)

- Completed NDA measurements of five metal standards using neutron coincidence counter in support of BIS

\section{Project W-460}

- Startup operation of the 234-5\% BTS was initiated September 30, 2000 following a successful readiness review and authorization by $R L$. This system accelerates packaging capabilities and reduces radiation exposure through automated packaging of plutonium-bearing material in welded stainless steel containers (Department of Energy Standard. D()E-STI)-3(013) for long term storage.

\section{SAFETY}

Lost Away Workday (ase Rate has had a significant decrease, with fourteen of fifteen months at zero. The current rate is exceptionally low. Occupational Safety and Health Act (OSHA) recordable case rate is stable and there have been more than 1.000 .000 hours since the last (OSHA recordable case. They have steadily reduced their OSI A recordable case rate through FY 190) and $\mathrm{FY} 2000$. This is a significant improvement in comparison to the adverse trend of spring 1999 .

FY 2000 OSHA case rate and DOE Safety Cost Index are very favorable. I)( )f: Safety ('ost Index has been below average for eight months in a row. The Index has a new average and new control li: its reflecting the significant decrease noted earlier in the ye:ar. 
10

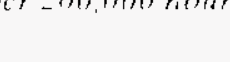

Avg $=1.6$
(Jan $96-$ Nov 96$)$

6

505,000

Hours

4

Lost Workday

2

f

0

Cas

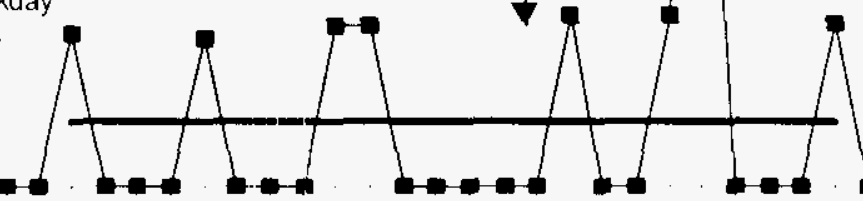

UCL

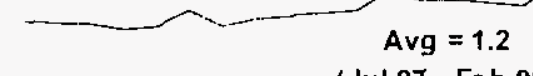

30

Green
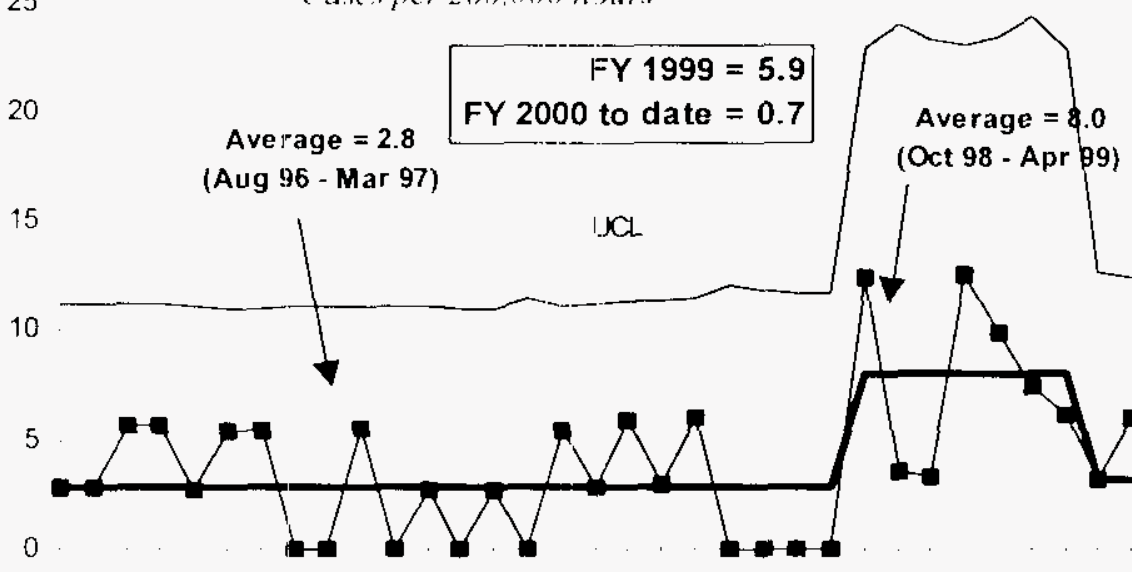

Project Safe Hours $=976,358$

FY $1999=1.6$

FY 2000 to date $=0.2$

\section{OSHA Recordable Case Rate \\ 25 \\ casesper 2000000 hours} Oct 98 - Apr 99) (May 99-Sep 99)

450

400

\section{DOE Safety Cost Index}

(entsperhour

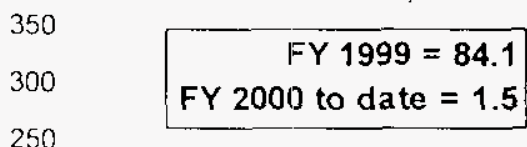

250

200

150

Avg $=10.4$

(Jul 96 - Mar 97)

100

50

50

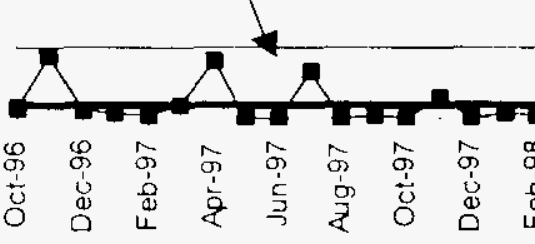

va

Avg $=4.8$

(Jul 99 - Jan 00)

Green
(Oct 99-Apr 00)
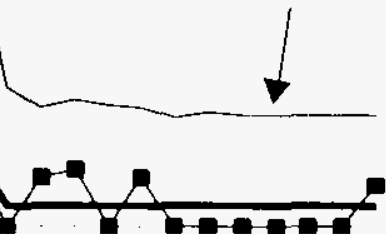

without Feb 99)
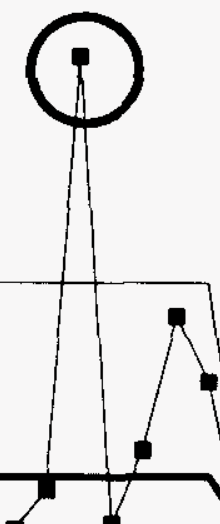

1

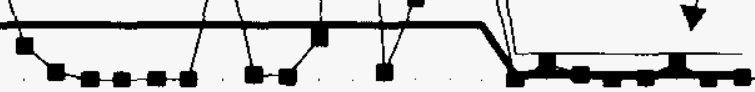

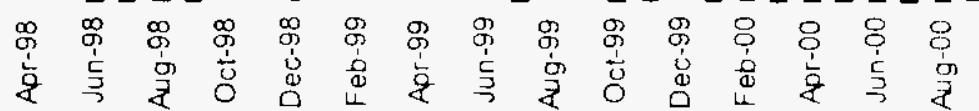

Month of Injury / Iliness 


\section{CONDUCT OF OPERATIONS / ISMS STATUS}

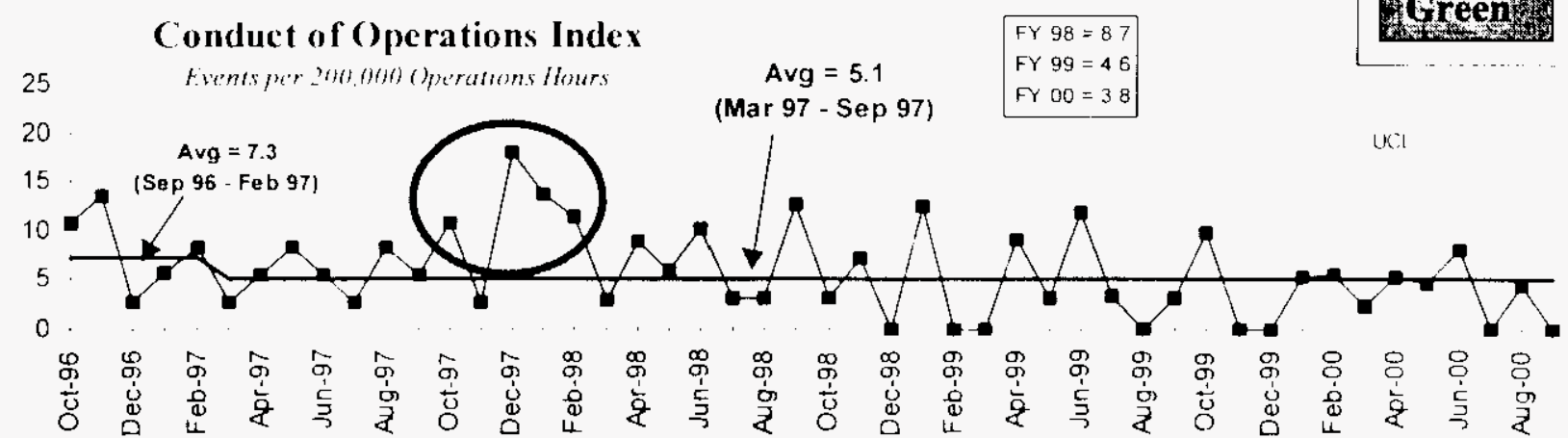

Number of Reports Past 12 Months

$\begin{array}{lllllllllll}0 & 2 & 4 & 6 & 8 & 10 & 12 & 14 & 16 & 18 & 20\end{array}$

Personnei Contamnation

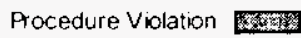

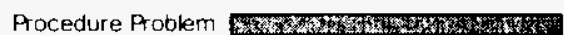

Training

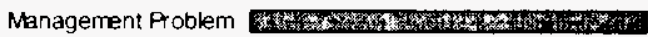

Lock and Tag

Work Control

\section{ISMS STATUS}

Continued safety improvements at PFP through ISMS:

- Refinement of the Automated Job Hazards Assessment (AJHA) tool and increased worker involvenient.

- Continued improvement in pre-job safety briclings.

- Improved field walk down of job sites.

- Improved metrics for work management and document development.

\section{BREAKTHROUGHS / OPPORTUNITIES FOR IMPROVEMENT}

\section{Breakthroughs}

- Tacilitated an agreement with Rocky Flats Environmental Test Site to purchase ()uter ('ans from Vendor and replace later. This resulted in avoiding a two-month schedule delay on the Outer Can Welder (OCW). 


\section{Opportunities for Improvement}

- Fil has scheduled an early November, 2000 visit to the Westinghouse Savannah River ('ompany (WSRC) to explore further opportunities for accelerated delivery of the 2736-7,B Bagless Transfer System and the OCW. Currently these items are expected to be shipped on January 8, 2001 and February 14, 2001, respectively.

- Exposure Reduction - Work continues on the ability to allow multiple tasks to be completed during a single zone entry. Ergonomic investigations reduced the likelihood of using heavy lead vests to reduce exposure. Development of new shielding and monitoring equipment continues.

\section{UPCOMING ACTIVITIES}

- Complete installation and startup of the Supercritical fluids Ixtraction equipment for I cosson-Ignition moisture measurıment in the first quarter of FY 2001.

- Delivery of the $2736-7 \mathrm{~B} 3 \mathrm{BIS}$ and $O \mathrm{CW}$ is expected during the second quarter of FY 2001.

- Stabilization and packaging of polycubes consistent with DOF: Standard DOI:-STI)-3013-99 is scheduled to begin in the third quarter of FY 2001.

\section{Cost Performance $(\$ M):$}

\begin{tabular}{|c|c|c|c|}
\hline & BCWP & ACWP & VARIANCE \\
\hline Nuclear Materials Stabilization & $\$ 123.1$ & $\$ 124.5$ & $-\$ 1.4$ \\
\hline
\end{tabular}

The $\$ 1.4$ million ( 1 percent) unfivorable cost variance is below the established variance reporting threshold. This perfomance does not reflect the NMS portion of PBS TP-12. The overall cost variance, if $[\mathrm{P}-12$ were factored in, would be a slightly favorable cost variance.

\section{SChedule Performance (\$M):}

\begin{tabular}{|l|c|c|c|}
\hline & BCWP & BCWS & VARIANCE \\
\hline Nuclear Materials Stabilization & $\$ 123.1$ & $\$ 123.9$ & $-\$ 0.8$ \\
\hline
\end{tabular}

The $\$ 0.8$ million ( 1 percent) ur favorable schedule variance is below the established variance reporting threshold. 


\section{FY 2000 Cost/Schedule Performance - All Fund Types Cumulative to Date Status - $(\$ 000)$}

FYTD

By PBS

WBS 1.4 .5 PFP

PBS TP05 Deactivation

Total

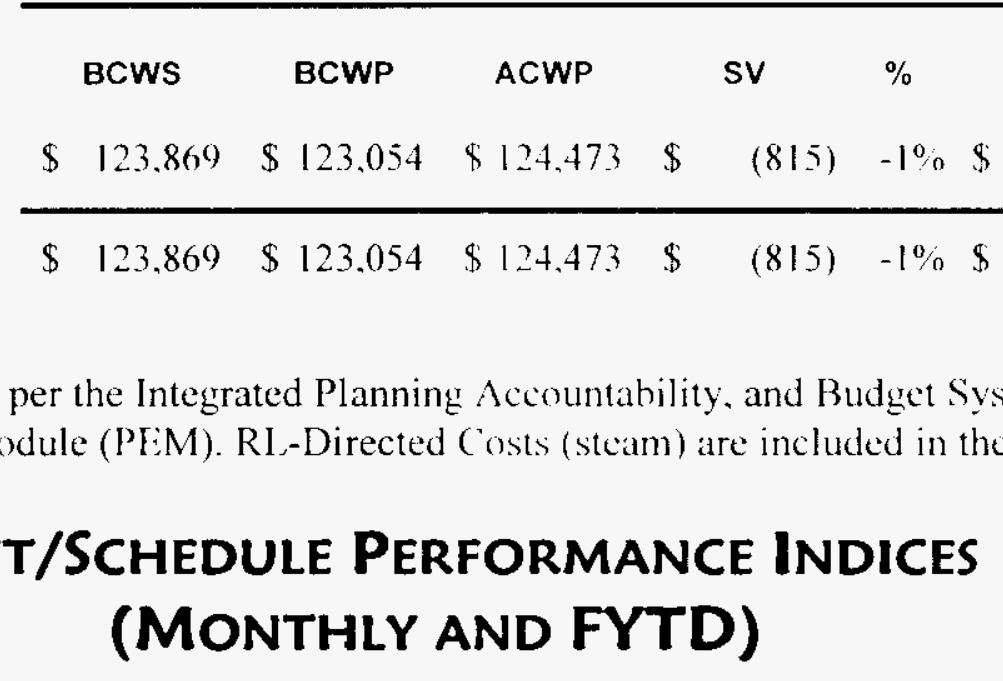

\section{Cost/SChedule Performance Indices}

Authorized baseline as per the Integrated Planning Aceountahility, and Budget System (IPABS)

- Project Execution Module (PEM). RL-Directed Costs (steam) are included in the PI:M BCWS

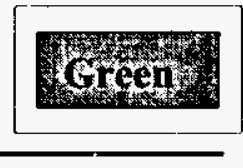

CV $\%$ 


\section{COST VARIANCE ANALYsIS: $(-\$ 1.4 \mathrm{M})$}

WBS/PBS

Tiutle

\subsection{3/TP05 Stabilization of Nuclear Materials $(-\$ 3.3 \mathrm{M})$}

Description and Cause: The unfavorable cost variance is due to additional resources required to support incremental design and installation workscope associated with the $\mathrm{Mg}(\mathrm{OH})$, project that was not in the original basis of estimate.

Impact: Delays in completion of construction activities have occurred but were remediated through judicious use of supplemental staff.

Corrective Action: No corrective action necessary. Construction has been completed and startup operation of this process was initiated September 20,2000. This variance is offset by under runs in Project Integration \& Business Management (TP-()12), positive credit variances (passbacks), fee allocation, and efficiencies in Safeguards \& Security of nuclear material.

\section{SCHEDUle VARIANCE ANAlysis: (- \$0.8M)}

\section{WBS/PBS}

1.4.5.1.14/TP05

Description and Cause: The unfavorable schedule variance is primarily duc to delays in obtaining NOC approval from the Washington Department of Health for 2736- $/ \mathrm{B}$ facility construction modifications required to support installation of the second Bagless Transfer System.

Impact: A potential delay is possible in the startup of the 2736-7B B'TS that may impact stabilization objectives in FY 2001.

Corrective Action: Peripheral 2736-ZB construction activities and continued discussions to accelerate BTS delivery with fatricator WSRC are expected to at least partially mitigate this variance. This schedule varianec is offset by the FY 2000 record setting performance in thermal stabilization. 


\section{FUNDS MANAGEMENT FUNDS US ACTUALS ( $\$ 000)$ \\ FY TO DATE THROUGH SEPTEMBER 2000 (FLUOR HANFORD, INC. ONLY)}

\begin{tabular}{|c|c|c|c|c|c|c|c|c|c|}
\hline & \multicolumn{3}{|c|}{ Project Completion. } & \multicolumn{3}{|c|}{ Post2006. } & \multicolumn{3}{|c|}{ Line llems : } \\
\hline & Expected Funds & FYSF & Variance & $\begin{array}{l}\text { Expected } \\
\text { Funds }\end{array}$ & FYSF & Variance & $\begin{array}{l}\text { Expectod } \\
\text { Funds }\end{array}$ & FYsF & Variance \\
\hline \multicolumn{10}{|l|}{ The Plateas } \\
\hline \multicolumn{10}{|l|}{15 Nuclear Materiats Stabilization } \\
\hline Line ltem & & & & & & & $1 \times, 1^{\prime}$ & $1 !, 18$ & 6.795 \\
\hline Total Nuclear Mat. Stab, Operating & s 115.637 & 113 & $5 \quad 1.867$ & & & & & & \\
\hline Tota! Nuclear Mat. Stab. Line Item & & & & & & & $1 \quad 18,58$ & $5 \quad 11,38$ & 50,745 \\
\hline
\end{tabular}

- Control Point

\section{ISSUES}

\section{Technical Issues}

Nothing to report at this time.

\section{DOE/Regulator/External Issues}

Nothing to report at this time. 


\section{Baseline Change Requests Currently in Process (\$000)}

\begin{tabular}{|c|c|c|c|c|c|c|c|c|c|}
\hline $\begin{array}{l}\text { PROJECT } \\
\text { CHANGE } \\
\text { NUMBER }\end{array}$ & $\begin{array}{l}\text { DATE } \\
\text { ORIGIN. }\end{array}$ & $\begin{array}{l}\text { BASELINE CHANGE } \\
\text { REQUEST TITLE }\end{array}$ & $\begin{array}{l}\text { COST } \\
\text { IMPACT } \\
\$ 000\end{array}$ & $\begin{array}{l}\mathrm{S} \\
\mathrm{C} \\
\mathrm{H}\end{array}$ & $\begin{array}{l}\mathrm{T} \\
\mathrm{E} \\
\mathrm{C} \\
\mathrm{H}\end{array}$ & $\begin{array}{l}\text { DATE TO } \\
\text { CCB }\end{array}$ & CCB APR'VO & RL APRVD & $\begin{array}{l}\text { CURRENT } \\
\text { STATUS }\end{array}$ \\
\hline$+S P 2000-001$ & 13001.99 & $\begin{array}{l}\text { Delele IRP } 99.419 \text { complete } \\
\text { insiall of procurtion scale } \\
\text { Vertical Calc ner }\end{array}$ & $\$ U$ & & & isariceled & & & o. Hold \\
\hline FSP $2000-043$ & 1-May-00 & Video Control cianera & $\$ 67$ & $x$ & $x$ & \multicolumn{3}{|c|}{ Deferred to FY 2001} & $\begin{array}{l}\text { Or hold due to } \\
\text { budget } \\
\text { constraints }\end{array}$ \\
\hline ISP $2000-045$ & $30 \cdot N C \vee-99$ & $\begin{array}{l}\text { Realign PFP D z-Inventory } \\
\text { SNM Shipments iAddendum I } \\
\text { Revisions) }\end{array}$ & $\$ 0$ & $x$ & $x$ & $13 \cdot \operatorname{sep} \cdot 00$ & $1350 p-1)$ & $29-5 e p \cdot 00$ & Complele \\
\hline$F S 巴-2000-0.50$ & $8 \cdot 5 \operatorname{sen} \cdot 00$ & $\begin{array}{l}\text { Project W- } 460 \text { Piacuce } \\
\text { Calorim etersiouter Can } \\
\text { Welder }\end{array}$ & $<\$ 1640$. & $x$ & $x$ & $16 \cdot$ Jun 00 & 31-Аแз-00 & $29 \cdot \operatorname{seg} 200$ & Completa \\
\hline FSP.2000-051 & 15 - Jun.00 & $\begin{array}{l}\text { HLPA Filter Visinerabilily } \\
\text { Assesment }\end{array}$ & $\$ 38$ & $x$ & $x$ & & Cancolled & & \\
\hline FSP.2000-053 & 1-May.00 & Backflow Proventers & $\$ 0$ & $x$ & $x$ & $31 \mathrm{Jul}-00$ & 2.Aisg 00 & 22 Aug 00 & Complete \\
\hline F SP-2000-061 & $13-J 41.00$ & Badgehouse $x$ ray Machine & $\$ 400$ & $x$ & $x$ & $31-3400$ & $3 \uparrow$ Aug 00 & $N / A$ & Complete \\
\hline FSP.2000-063 & 17 Jul-00 & Rebaseline Prosert W. 460 & $\$ 5456>$ & $x$ & $x$ & $7-\operatorname{sep} \cdot 00$ & $7 \operatorname{sep} 00$ & $29-\operatorname{Sep} 00$ & Compiete \\
\hline FSP.2000-069 & $20-J u 1.00$ & $\begin{array}{l}\text { Rebaseline rP 12. Transition } \\
\text { Project Manajem ent (life } \\
\text { cycle) }\end{array}$ & IBD & $x$ & $x$ & \multicolumn{3}{|c|}{ Deterred to FY 2001 with Phase II } & In work \\
\hline FSP-2000-062 & $20-30100$ & $\begin{array}{l}\text { PFP Residues Satinzation } \\
\text { FYOORebaselire }\end{array}$ & $-\$ 343>$ & $x$ & $x$ & $13-5 e p-00$ & $13-5 e p .00$ & 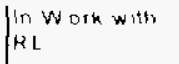 & in wioth \\
\hline FSP-2000-074 & $20-J u 1.00$ & $\begin{array}{l}\text { Rebaseline PFF Folycube } \\
\text { Stabilizalion }\end{array}$ & $\times \$ 612 x$ & $x$ & $x$ & $13-\operatorname{sep}-00$ & $13-\mathrm{Sep} .00$ & $29580-00$ & Complete \\
\hline FSP-2000 079 & 15. Aug.00 & $\begin{array}{l}\text { FY } 2001 \text { MYWF' B Baseline } \\
\text { Revisions }\end{array}$ & $\$ 0$ & $x$ & $x$ & 29. Aug.00 & 31-Aug 00 & At R! & $\begin{array}{l}\text { Apwoved } 26- \\
0 \mathrm{Cl}-\mathrm{uO}\end{array}$ \\
\hline FSP-2000088 & 21 sep.00 & $\begin{array}{l}\text { MglOH)Z Prezplalion } \\
\text { Workscope Increases }\end{array}$ & $\$ 1672$ & & $x$ & $28-5 e p \cdot 00$ & $14-\operatorname{sep} .00$ & $295 \theta p-00$ & Complete \\
\hline $\mathrm{FH}-2001-001$ & $12.5 \theta p .00$ & $\begin{array}{l}\text { Base OpsReituction for } \\
\text { PHMC Propects }\end{array}$ & $(\$ 6790)$ & & $x$ & & & A $\mathrm{RL}$. & Orafl Prepared \\
\hline $\mathrm{FH}-2001.002$ & $25-\operatorname{sep} p .00$ & $\begin{array}{l}\text { FY } 2001 \text { Fea Reduction to } \\
90 \%\end{array}$ & $(\$ 600)$ & & & & & & Drati Prepared \\
\hline FH 2001-003 & 25 Sep-00 & $\begin{array}{l}\text { FY } 2001 \text { Addition of High } \\
\text { Priorily Workscogi? }\end{array}$ & 50.767 & & $x$ & & & & Draft Prepaled \\
\hline \multicolumn{10}{|c|}{ ADVANCED WORKAUTHORIZATION } \\
\hline AWA-01001 & & $\begin{array}{l}\text { Tanks } 241-7 \cdot 361 \text { Inciemental } \\
\text { Work }\end{array}$ & $\$ 250$ & $x$ & $x$ & $10-0 \mathrm{ct} .00$ & $10.001-00$ & $18.0 \mathrm{ct} .00$ & Complet \\
\hline AWA-01002 & & $\begin{array}{l}\text { PfP Parking I.o: } \\
\text { Enhancements }\end{array}$ & $\$ 150$ & $x$ & $x$ & & & & \\
\hline
\end{tabular}

Milestone ACHIEVEMENT

\begin{tabular}{|c|c|c|c|c|c|c|c|c|}
\hline \multirow[b]{2}{*}{ MULES TONE: TYPE } & \multicolumn{4}{|c|}{ FISCAL YEAR-TO-DATE } & \multicolumn{3}{|c|}{ REMAINING SCHEDULED } & \multirow[b]{2}{*}{$\begin{array}{l}\text { TOTAL } \\
\text { FY } 2000\end{array}$} \\
\hline & $\begin{array}{c}\text { Completed } \\
\text { Early }\end{array}$ & $\begin{array}{c}\text { Completed } \\
\text { On } \\
\text { Schedule }\end{array}$ & $\begin{array}{c}\text { Completed } \\
\text { Late }\end{array}$ & Overdue & $\begin{array}{c}\text { Forecast } \\
\text { Early }\end{array}$ & $\begin{array}{l}\text { Forecast } \\
\text { On } \\
\text { Schedule }\end{array}$ & $\begin{array}{c}\text { Forecast } \\
\text { Late }\end{array}$ & \\
\hline Enforceable Agreement & 1 & 1 & 0 & 0 & 0 & 0 & $\overline{0}$ & 2 \\
\hline $\mathrm{DOE}-\mathrm{HQ}$ & 의 & 0 & 0 & 1 & 0 & 0 & 0 & 1 \\
\hline $\mathrm{RL}$ & 5 & 0 & 4 & 1. & 0 & 0 & 0 & 10 \\
\hline Total Project & 6 & 1 & 4 & 2 & 0 & 0 & 0 & 13 \\
\hline
\end{tabular}

(Only TPA/FA milestones and all FY2000 overduc and forecast late milestones are addressed in this report. Milestones overduc are deleted from the Milestone Exception Report once they are completed. The following chart summarizes the FY2000 IPA/LA milestone achievement and a Milestone lixception Report follow's. 
PHMC Environmental Management Performance Report - November 2000

Section C: I - Nuclear Materials Stabilization

Tri-Party Agreement / EA Milestones

Tri-Parly Agreement Milestone M-15-37A (TRP-()0-501). "Deliver Two (2)

Tank Z-241-Z-361 Core Samples to 222-S", duc 10/30/99

- Completed 1 month early (9/28/99)

Tri-Party Agreement Milestone M-015-37B (TRP-()0)-511). "Deliver Core"

Sample Data Packages for Tank 241-Z-361 Disp”, due 5/31/00)

- Completed (On Schedule

DNFSB Commitments

DNFSB Milestone IP-113 (TRP-00-500), "Install 2 I.ANL.

Pyrolysis Units for Stabilization of Polycubes at PFP". due 12/31/99

- The Defense Nuclear Facility Safety Board (DNFSB) 2000-1 Implementation

Plan update deletes this milestone in favor of stabilization via muffle furnaces.

\section{MILESTONE EXCEPTION REPORT}

\section{Number/WBS Level \\ OVERDUe -2}

Milestone Title

Baseline

Date

Forecast

Date

TRP-00-500 HQ

1.4.5
Install Two Los Alamos National

Laboratory (LANL) Pyroly'sis I nits for Stabilization of Polycubes

Cause: See DNFSB Commitment above.

Corrective Action: Baseline Change Request (BCR) FSP-2000-074 was approved on September 29 and authorizes removal of pyrolysis stabilization of polycubes and implements thermal stabilization in its stead has been approved by $\mathrm{RL}$, and implemented into the baseline.

TRP-00-504 RL Restart Cementation Operations $\quad 04 / 21 / 00$ C'ancelled

1.4 .5

Cause: Stabilization processing has been re-sequenced. Startup of the Pipe-N-Go process packaged $29 \mathrm{Kg}$ bulk residue (Rocky Flats $\Lambda$ sh) in FY 2000). This milestone has been cancelled via BCR FSP-2000-079.

Corrective Action: None, as the global stabilization end point will remain the same.

\section{FY 1999 OVERDUE - 2}

TRP-99-419 RL Complete Installation of Production

1.4 .5

Scale Vertical Calciner
$09 / 30 / 99 \quad$ Proposed

1)eletion

Cause: The production scale vertical calciner has been replaced with the Magnesium Hydroxide Precipitation process.

Impact: No impact. This milestone is obsolete.

Corrective Action: Since installation and testing of the production scale vertical calciner is an L:M-65 Management Commitment; the RL change control process cannot remove this milestone Solution stabilization began on September 20, 2000. 
PHMC Environmental Management Performance Report - November 2000

Section C: 1 - Nuclear Materials Stabilization

TRP-99-500 HQ Complete Installation \& Testing of $\quad 09: 30 / 99$ Deleted
1.4 .5
Production Vertical Calciner

Cause: The production scale vertical calciner has heen replaced with the Magnesium Hydroxide Precipitation process.

Impact: No impact. This milestone is obsolete.

Corrective Action: The Defense Nuclear Facility Salety Board (DNFSB) 2000-1

Implementation

Plan update deletes this milestone.

\section{Performance Objectives Oxides/Metals/Polycubes Stabilization}

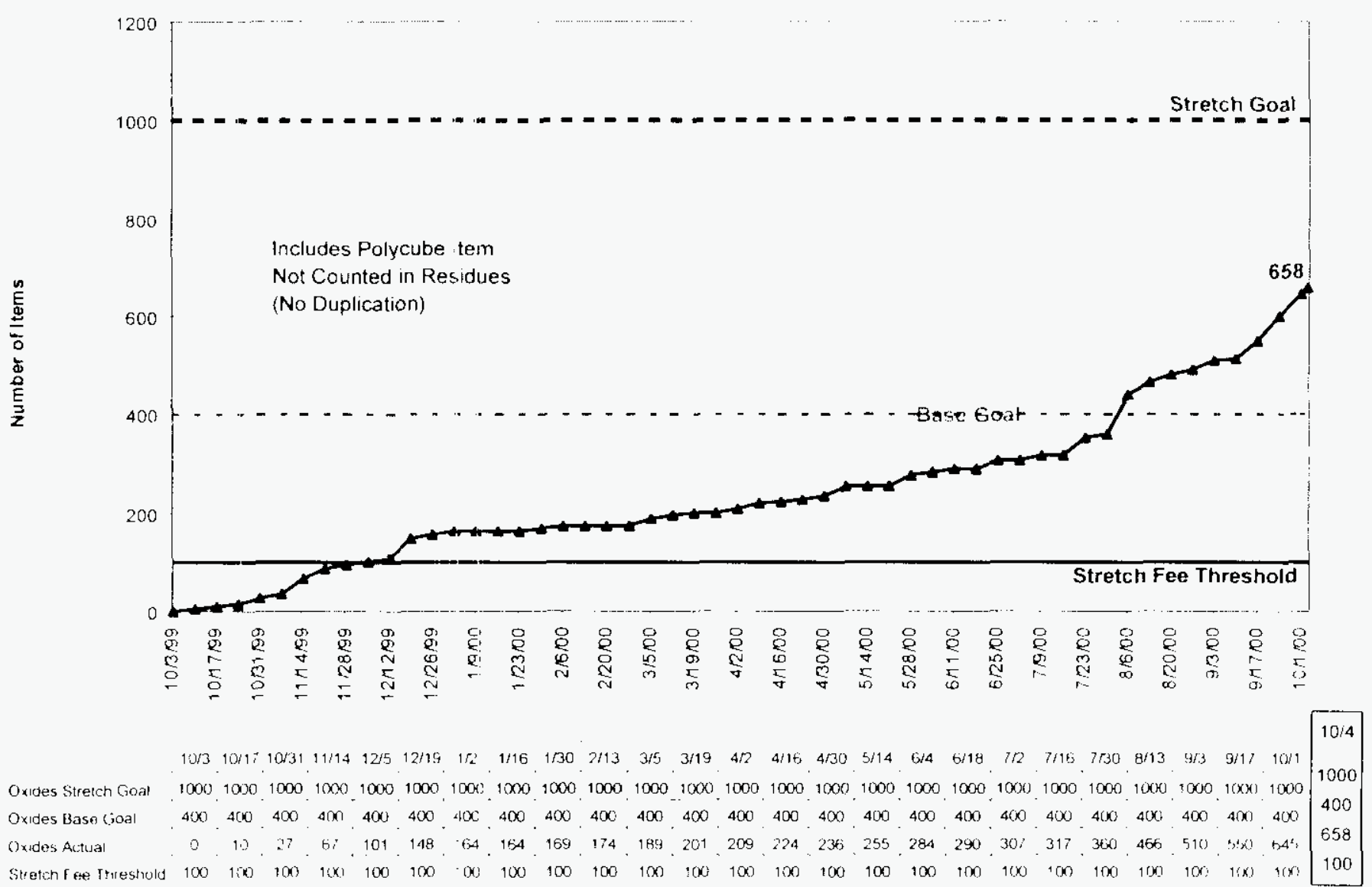

Thermal stabilization of more than 650 plutonium-bearing items during F Y 2000 represented a four-fold increase over FY $1999^{\circ}$ s production level. 


\section{Solution Stabilization}

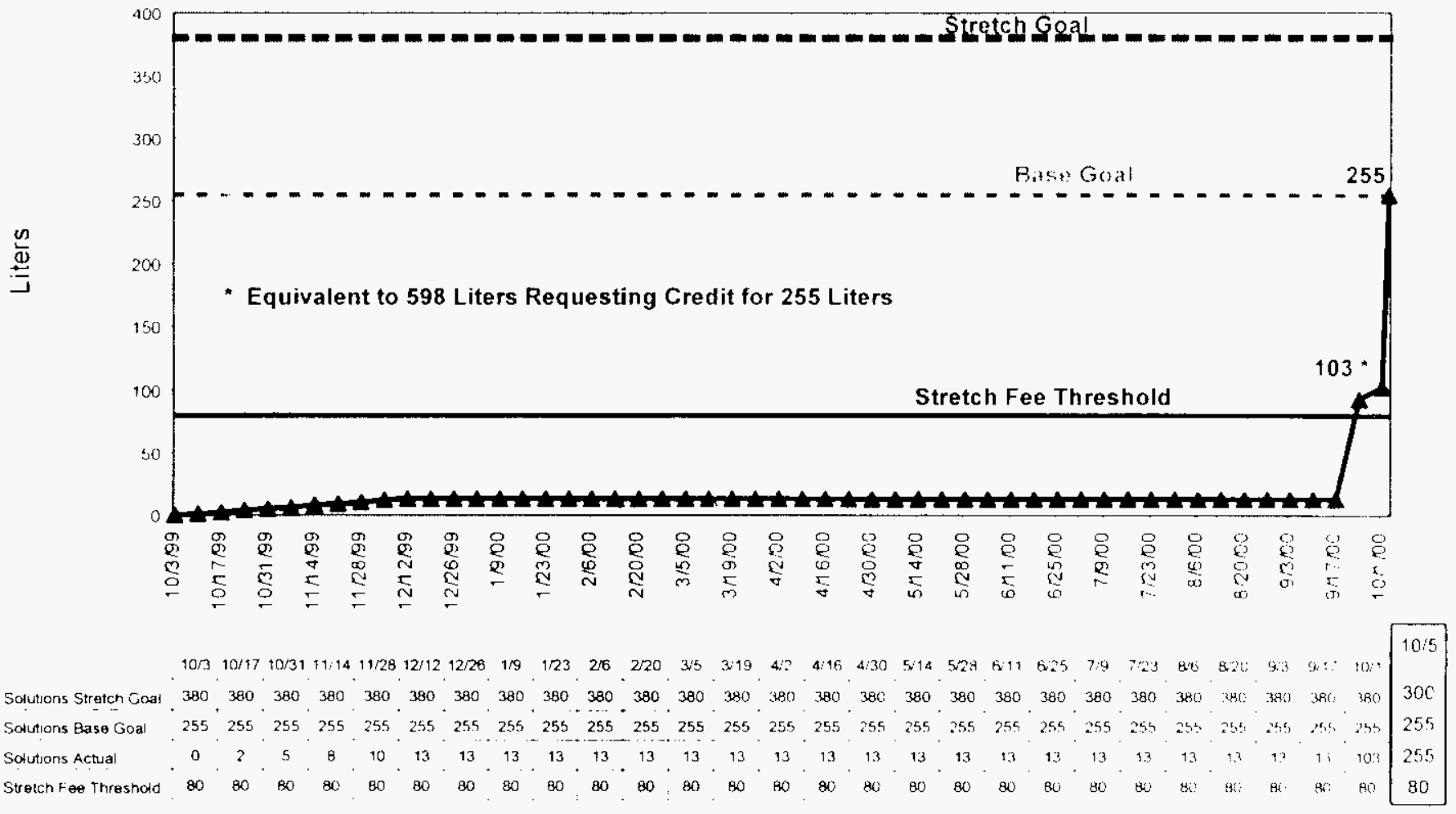

Operation of the $\mathrm{Mg}(\mathrm{OH})_{2}$ process began September 20, 2000, and met the stretch goal gateway criteria

\section{Residues Stabilization}

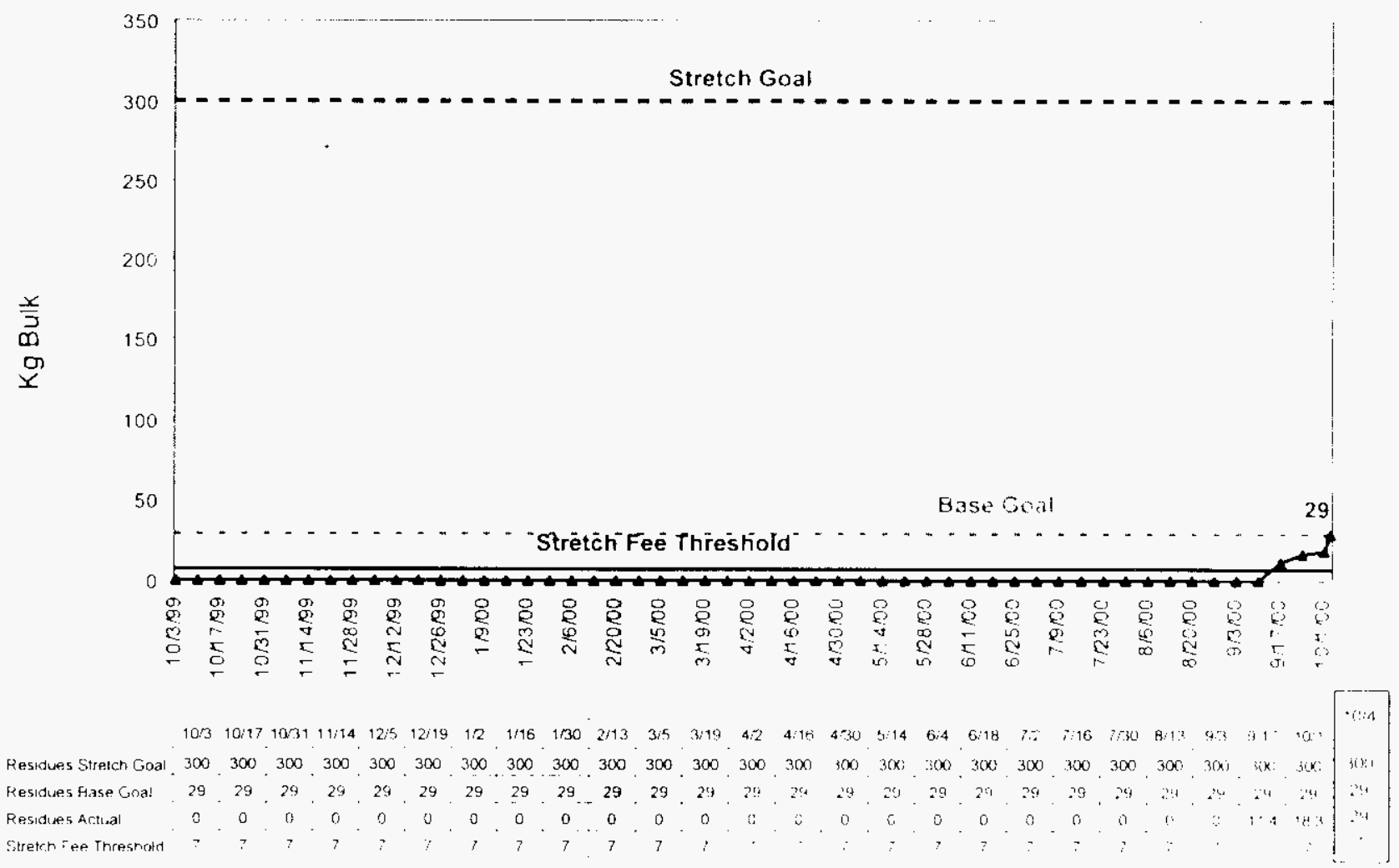

Repackaging of plutonium-bearing residues began September 11,2000, and met the base groal target 


\section{KEY INTEGRATION ACTIVITIES}

- Continued support to the (entral Waste Complex in completing activities necessary to allow acceptance of packaged residues. This support included security upgrades and issuance of Criticality Safety Evaluation (CSER) and SARP documentation.

- FH has scheduled an carly November 2000 visit to the WSRC' to explore further opportunities for accelerated delivery of the 2736-7/B BTS and the OCW. Currently, these items are expected to be shipped on January 8, 2001, and February 14, 2001, respectively.

\section{Nuclear Materials Stabilized During the Current Period}

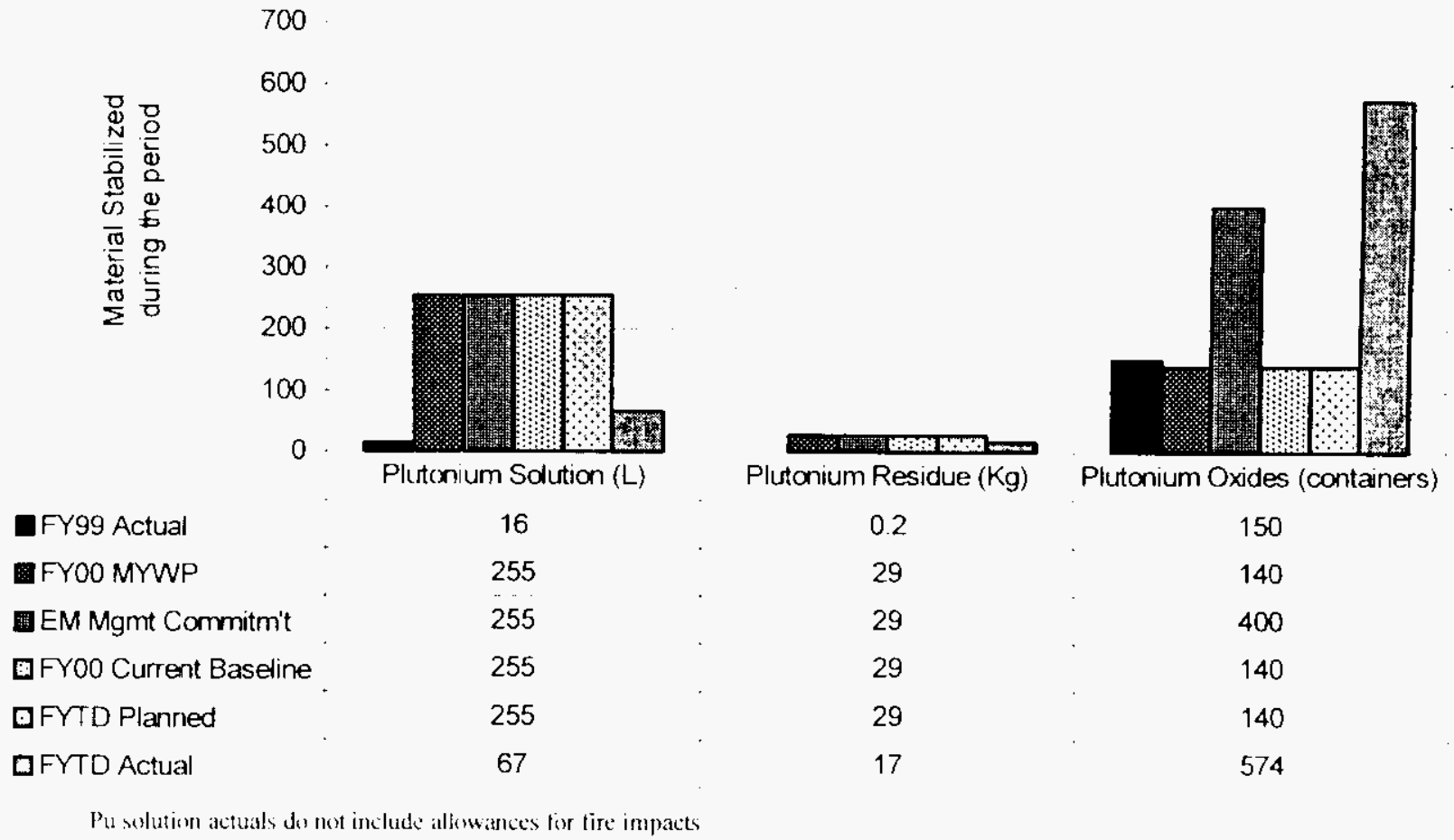

Plutonium Solution: Implementation of the $\mathrm{Mg}(\mathrm{OH})_{2}$ process was 9 weeks later than planned resulting in less processing.

Plutonium Residue: Repackage of plutonium resides was initiated 8 weeks late after PFP implemented a pipe-n-go process method.

Plutonium Oxides: Approval of LIS via supplement analysis increasing charge size of furnaces by a factor of 4 and increasing the number of furnaces from 2 to 5 has allowed the actual stabilization to proceed faster than planned. In addition, metal/oxide stabilization was extended thru the fourtl quarter as stabilizing the other forms of plutonium were implemented later than planned. 


\section{BUILDING DeActivation}

70

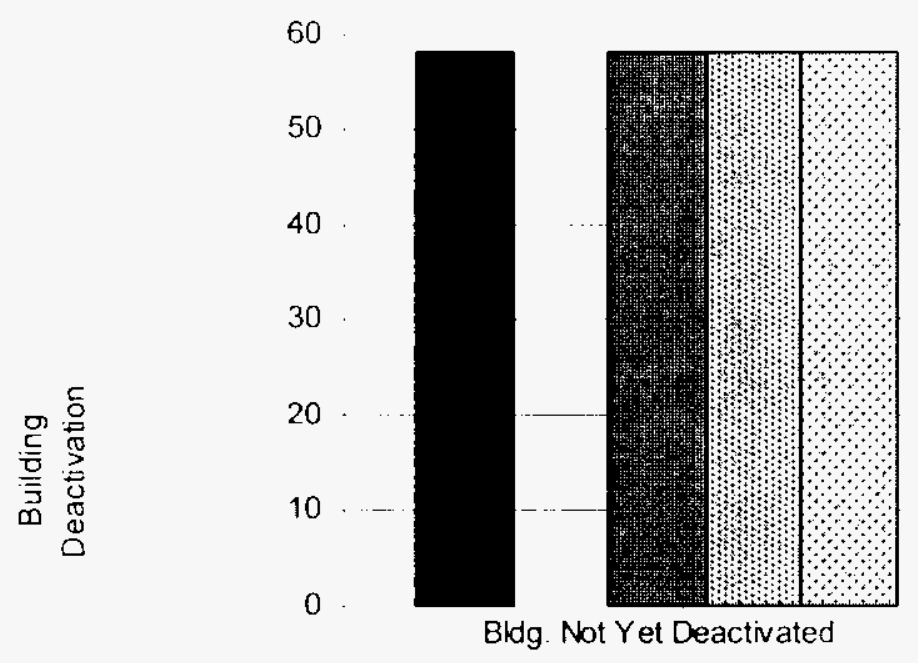

1. FYOO MYWP

58

Post Deactivation

ㅂ.

암 Fuo Current Baseline

0

0

มFYTD Planned

58

0

0

QFYTDActual

58

0

58

0

Buildings Not Yet Deactivated: Deactivation of buildings will not begin until F Y 2009 as documented in the Integrated Project Management Plan for the River Corridor

Post Deactivation: There are no buildings in post deactivation. 

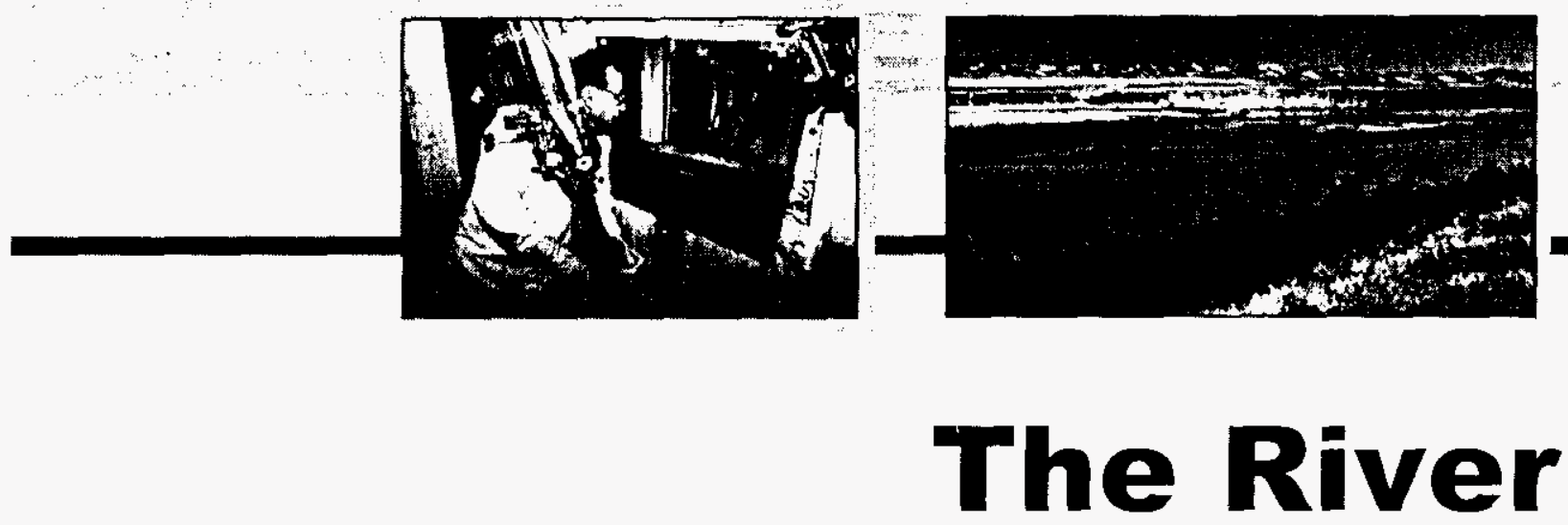

Restoring the river corridor is one of the outcomes Hanford must focus on to move forward with cleanup. The PHMC supports this outcome with activities such as moving the spent nuclear fuel, cleaning up the waste sites, and taking down surplus facilities. Projects supporting this effort are Facility Stabilization (River Corridor), Spent Nuclear Fuel, and Science \& Technolo: (EM-50) activities. 

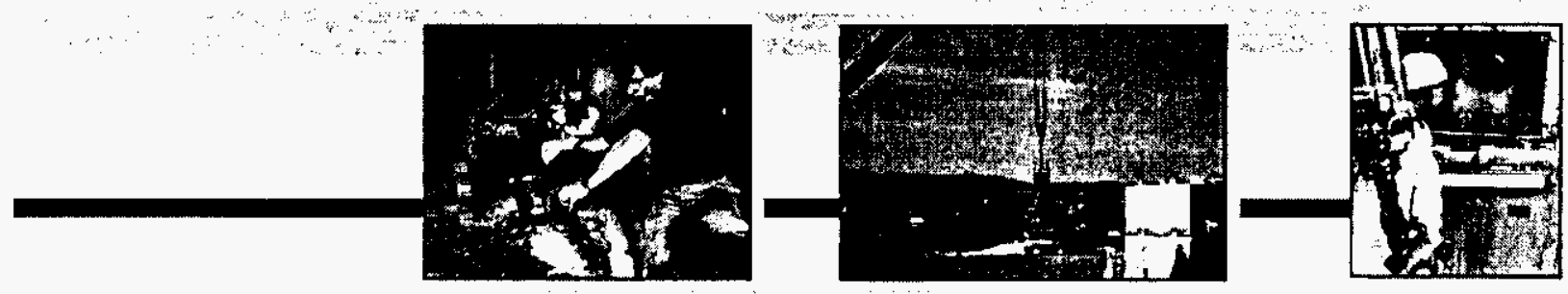

\section{Section C:2 River Corridor}

PROJECT MANAGERS

P.M. Knollmeyer, RL (509) 376-7435

N. Boyter, FH (509) $373-3725$ 


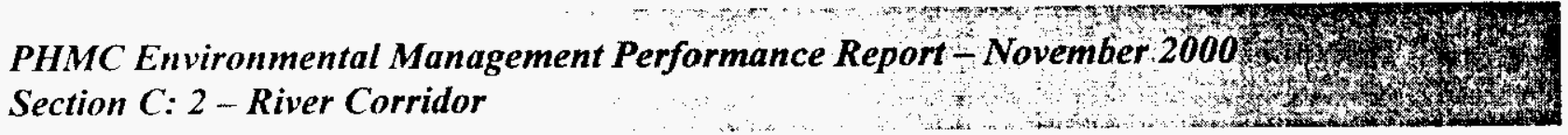

\section{SUMMARY}

The River ('orridor Project consists of the following projects: 300 Area Liquid Fffluent Facility (LEF) WBS 1.2.3.2, Project Baseline Summary (PBS) WMO5: B-Plant. WBS 1.4.1. PBS TPO)1: $300 \mathrm{Area} /$ Special Nuclear Materials. WBS 1.4.4. PBS 1P04: Transition Project Management. WBS 1.4.6. PBS TP12; Accelerated Deactivation, WBS 1.4.8. PBS TP10: 324/327 Facility Transition. WBS 1.4.10, PBS TP08; and Hanford Surplus Facility Program (300 Area Revitalization), WBS 1.4.11, PBS TP14.

PBS WM05 is divided between WBS 1.2.3.1, Liquid Eftluents (200 LLF) and WBS 1.2.3.2. 310 TEDF/340 Facility (300 L.EF). The 310 TEDF/340 Facility work scope is now included in the River Corridor Project, whereas the Liquid Effluents (200 L LEF) work scope has remained in Waste Management. For the purpose of performance analysis. PBS WM05 is reported in its entirety in the Waste Management Project, which has the majority of the itork scope and funding incorporated in their baseline.

NOTE: Unless otherwise noted, all information is as of September $30,2000$.

\section{Top 5 Accomplishments for FY 2000}

All $184 \mathrm{~T}$-hoppers containing approximately 667 metric tons of low-enriched uranium in the form of uranium trioxide powder were shipped to the DOE Portsmouth site in Ohio by September 28, 2000, an accelerated target date (Completion and Removal).

Key 327 Building cleanup accelerated from the out years was accomplished during FY 2000 . These activities included packaging and shipping $32.5 \mathrm{~m}^{3}$ of bulk waste (exceeding the fiscalyear target), packaging and shipping 103 legacy waste buckets to compliant storage ( 28 more than planned); and packaging and shipping to the 200 Areas Waste (omplex 90 percent of the 297 sample sans of radioactive materials from dry storage. All eight fuel pins were packaged and shipped; cleanout of H Cell was completed; and all accountable fissile material in hot cells was packaged and shipped (Momentum).

324 B Cell Cleanout - Milestone RI. TRP-99-936, “2A Rack Removal and Size Reduction...." was completed three weeks early, and RI, Milestone TRP-99-907. "1 A .3-82B Cask Shipments..." was completed seven days early, with all 17 grout containers scheduled for this year shipped (Momentum).

On June 30, 2000 the 300 Area Accelerated Closure Project Plan was submitted to RI.. The submittal completed the deliverable to develop an innovative and integrated plan. schedule, and cost estimate for the accelerated closure of a significant portion of the 300 Area (Momentum).

Over 57 million gallons of wastewater were treated at the 300 Area Treated Effluent I)isposal Facility (THDF) (Progress). 


\section{Additional FY 2000 Accomplishments}

\section{Momentum}

River Corridor Project and COCEMA Engineering worked together on the design and procurement of a robotic crawler to be used for the cleanup of the 324 Building. Hot-cell technicians will use the crawkr. which has a light duty arm and vacuum system, to collect material from the sump, trench and floor of $B$ Cell. There were no existing tools able to complete the task. The versatility for multiple tool deployment allows access to hard-to-reach areas within the cell.

\section{Progress}

The RCP has worked an estimated 1,308,000 safe hours since the last lost time injury.

The Fuel Supply Shutdown Waste Acid Treatment System (WATS) Resource Conservation and Recovery Act of 1976 (RCRA) Closure Project was selected as the Project Management Institute's Regional Project of the Year award winner at the $\Lambda$ wards Banquet on March 15, 2000.

'Two steel waste disposal boxes containing mixed waste were shipped to the Central Waste Complex (CWC) in support of "l'ri-Party Agreement Interim Milestone M-89-02, 2000. "Complete removal of 324 Building Radiochemical Engineering (ell (REC) B Cell Mixed Waste (MW) and Equipment," due November 30. The 324 staff successfully shipped 80 of 88 backlog low-level waste drums, and completed lead shield plug size reduction and packaging.

$\Lambda$ biological clean-up procedure for 200 Area Accelerated Deactivation Project was cited as a major strength by ISMS assessows, and as a positive observation per RL surveillance.

Additionally, installation of the second backflow preventor at 231-Z Facility was completed one month ahead of schedule.

The 300 Area Liquid Effluent Facility received and processed eleven 33-gallon drums of sodium hydroxide, which resulted in avoidance of a $\$ 31.6 \mathrm{~K}$ disposal cost. Additionally, eight 55 -gallon drums of sulfuric acid were unloaded into the 310 Facility sulfuric acid storage tank. This acid was excess product from the 200 Area Effluent Treatment Facility. Ise of the excess acid will climinate the need for disposal of the product as hazardous waste and result in a cost avoidance of $\$ 112.7 \mathrm{~K}$.

\section{Completion and Removal}

B Plant closeciut activities were completed 10 days ahead of the Washington Department of Health (WDOHI) due date of J Iy 28, 2000. Bechtel Hanford, Inc. assumed full responsibility for surveillance and maintenance of $B$ Plant and the associated ventilation system on August 9.

Fiscal-year-to-date milestone performance (FA, DOE-HQ, and RL) shows that four of five milestones $(80$ perent) were completed on or ahead of schedule and one milestone is overdue. The Milestone Achievement details, found following cost and schedule variance analysis, provide lurther information on all milestone types. 


\section{Accomplishments this Reporting Period}

- For the month of September the 327 Building personnel shipped an additional 12 lead-lined drums and 9 concrete-lined drums to the Central Waste ('omplex. ()ne box of bulk waste was shipped to the burial grounds, 63 legacy waste buckets and 240 grams of I )ry Storage/Metallurgical Mount fissile material was shipped to compliant storage, and the cleanout of H Cell was completed.

- The Uranium Disposition Project (TP-14) completed shipment of 36 T-hoppers to the I)(OF: Portsmouth site in Ohio this reporting period. Additionally, 200 Area personnel recovered approximately $\$ 100 \mathrm{~K}$ worth of scaffolding materials from PUIREX for reuse

- The 300 Area Treated Effluent Disposal Facility treated 5.2M gallons of wastewater for the month of September. In addition, the Process Sewer cleanout and the precipitation testing process were completed.

- The 324 Building personnel loaded out and shipped the first two steel waste disposal boxes. replaced HEPA filters, replaced oil in 23 Hot Cell windows, and completed size reduction of rectangular grout container- 3 . In addition, grout container-120 was dose profiled and transferred to A Cell.

\section{SAFETY}

The project has exceeded 1,321,926 hours without a Lost Away Work Day Case (21 months, since January, 1999).

As of September, four OSHA recordable cases were recorded, breaking the run of no (OSHA recordable cases since May 1999. One case was a report from June 1999 that reclassified to OSHA recordable, and three new cases in August. Although the OSHA recordable case rate is still low, the sudden arrival of four cases after such a long lull in injuries should be examined to see if it is an adverse trend.

There were also four first aid cases in September, a relatively high number for RCP. The project had 726,000 hours from August 1999 through July 2000 between (OSHA Recordable (ases. The project has an overall green rating. 


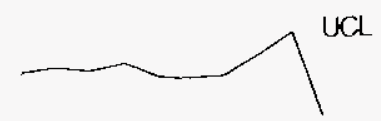
a Lost Aw ay Work [ay/ Case (Dec 96 - Mar 98)

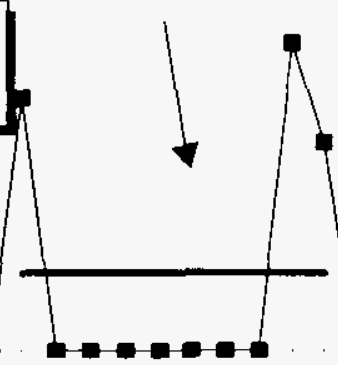

2

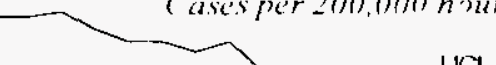

(Oct 96 - Nov 98)

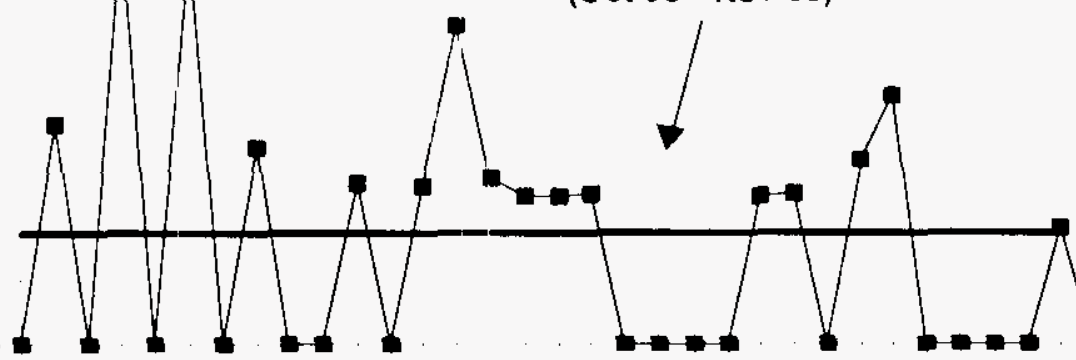

120

100

80

80

60

40

20

\section{DOE Safety Cost Index}

cents per hour
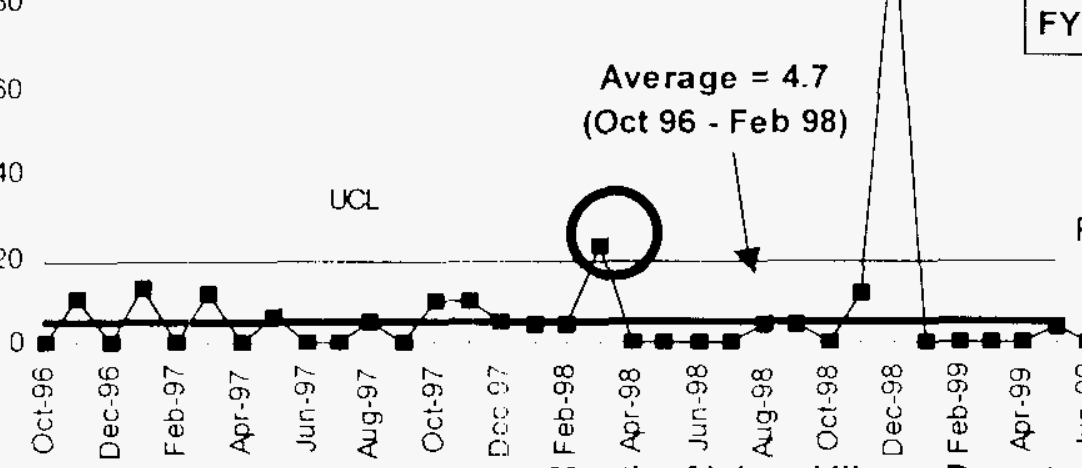

Month of Injury / IIIness Reported
Yellow

FY $1999=1.3$

FY $2000=1.0$

Average $=3.0$

(Jun 00 - Sep 00)

726,000 hours between OSHA

Recordable Cases

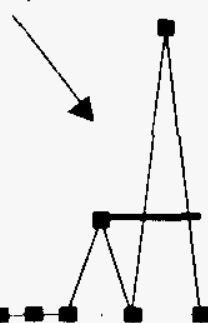

Green

FY $2000=1.0$

726,000 hours between OSHA Recordable Cases 


\section{CONDUCT OF OPERATIONS / ISMS STATUS}

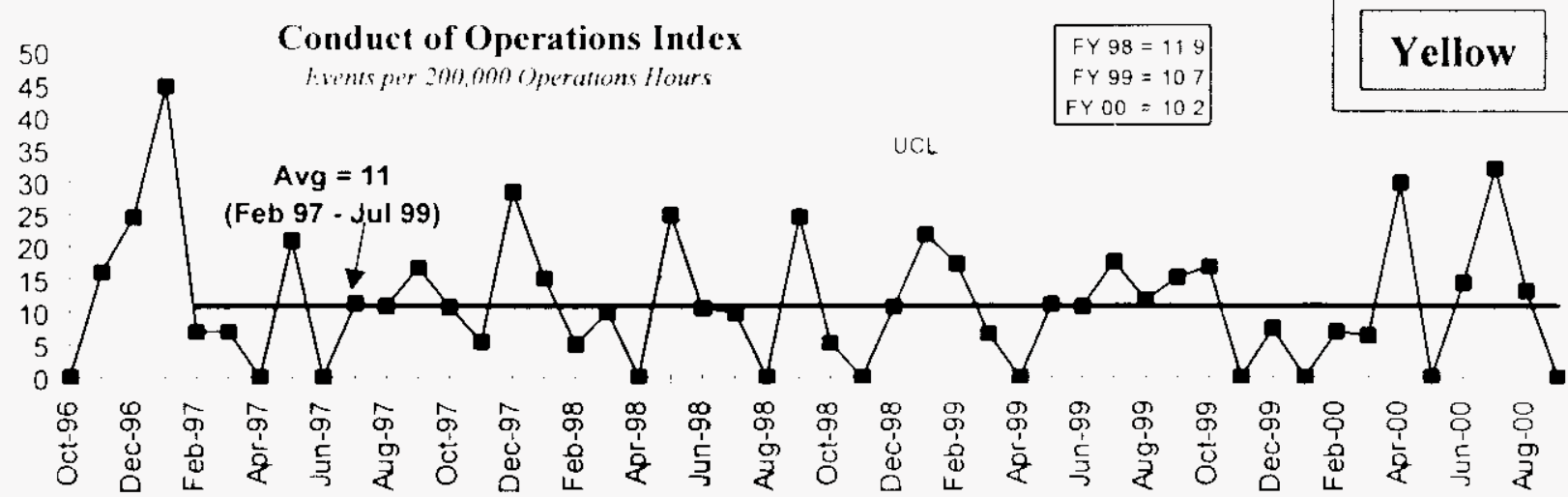

Number of Reports Past 12 Months

$\begin{array}{lllllllllll}0 & 2 & 4 & 6 & 8 & 10 & 12 & 14 & 16 & 18 & 20\end{array}$

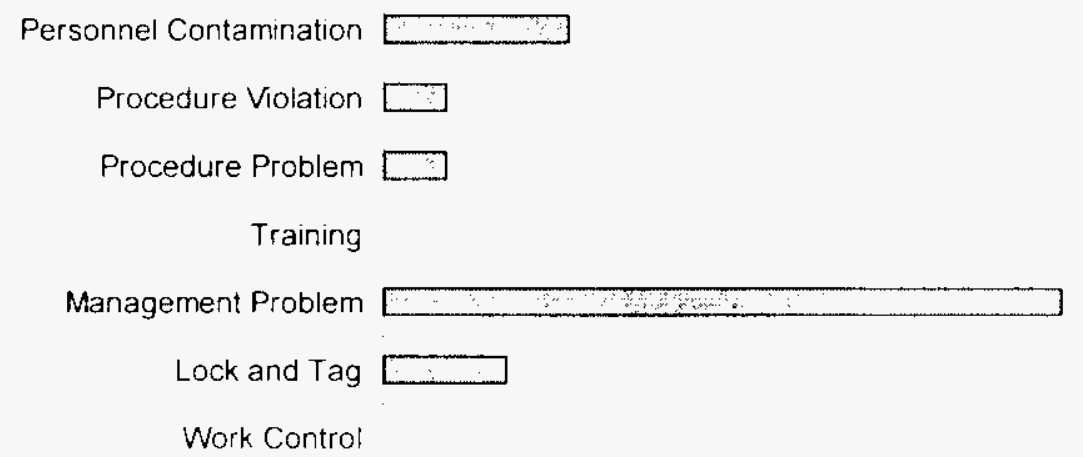

Analyzing occurrence reports to determine contributing factors and subsequent appropriate action(s) to address the number of Management Problems reported.

\section{ISMS STATUS}

\section{Green}

- ISMS Internal Readiness Review (IRR) completed.

- Phase I Verification successfully completed April 28. 2000.

- Ieclared Readiness for ISMS Phase II Verification May 2. 2000.

- ISMS Phase II Verification successfully completed July 13,2000.

- Hazard Analysis Management Assessment completed: Lessons Learned developed. 


\section{BREAKTHROUGHS / OPPORTUNITIES FOR IMPROVEMENT}

\section{Breakthroughs}

- Savings Through Alternative Disposition Strategy - Final disposition of L iniradiated l ranium fuel elements to low-level waste burial grounds vs. packaging and transportation to Portsmouth. Ohio for interim storage will save in excess of $\$ 1$ million.

- 300 Area Accelerated Closure Plan - Based on the preparation of the 300 Area Accelerated Closure Plan an opportunity exists to accelerate closure of a significant portion of the 300 Area nearly four decades ahead of the current deactivation plan for an estimated savings of over $\$ 1.0$ billion. Provided basis for new "Done-in-a-Decade" closure project.

\section{Opportunities for Improvement}

- 324 Project Planning / Execution - An emphasis on improved schedule management to ensure that critical path negative float is recovered to positive float continues. Although two steel waste disposal boxes (SWIDBs) were

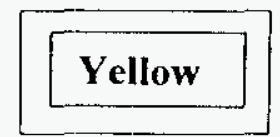
successfully shipped in FY 2000, the Tri-Party Agreement Milestone M-89-()2 (due November 30,2000 ) critical path schedule now reflects a 21-day negative float for shipment of the remaining SWDBs. Higher than anticipated SWDB bottom plate doses have added additional work scope to the schedule.

- 327 Building Conduct of Operations --- Deactivation project work activities were temporarily curlailed by the facility management to focus efforts on procedure upgrades and Conduct of Operation concerns.

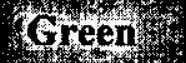
After a five-week effort, two months of successful deactivation work was initiated utilizing the new procedures. Senior management reviewed the daily work planning and work evolutions in the facility for areas of continued improvement. Significant facility cleanup progress was made during the last two months of the fiscal year as a result of the management action taken.

\section{UPCOMING ACTIVITIES}

- TPA Milestone M-89-02 --- Complete Removal of 324 Building Radiochemical Engineering Cell (REC) B (ell Mixed Waste (MW) and Equipment. Delays incurred by higher than assumed dose readings for the SWDBs. recently identified operational issues, and emerging issues; e.g. 30-ton crane repair. indicates the work to complete the milestone will not finish until beyond the November 30, 2000 milestone date. A plan for completing the remaining scope is in development. Finalization of the plan will be done in conjunction with $D())$ : and the I epartment of Ecology.

- Facility Evaluation Board Review - Complete Facility lvaluation Board review during first quarter of FY 2000. 
- 324/327 Authorization Basis - Implement technical update of 324 Authori/ation Basis (Safety Analysis Report) by mid-December, $2000($ and implement technical update of 327 Authorization Basis (Basis of Interim (Operation) by March 2001.

- Uranium Disposition - Complete shipment of approximately 235 metric tons of excess uranium billets and approximately 5 metric tons of uranium dioxide to the DOE Portsmouth site in (Ohio by March 31,2001 and disposition approximately 140 metric tons of surface contaminated uranium fuel by June $30,2001$.

- 324 B Cell Cleanup - Complete shipment of B Cell waste currently stored in A Cell to the 200 Areas by July $31,2001$.

\section{Cost Performance (\$M):}

\begin{tabular}{|l|c|c|c|}
\hline & BCWP & ACWP & VARIANCE \\
\hline River Corridor Project & $\$ 60.5$ & $\$ 51.9$ & $\$ 8.6$ \\
\hline
\end{tabular}

The $\$ 8.6$ million ( 14 percent) favorable cost variance is primarily from underruns in min safe 324 and 327 budgets and the Fluor Project Management Team re-structuring. Further information at the PBS level can be found in the following Cost Variance Analysis details.

\section{SChedule Performance ( $\$ M)$ :}

\begin{tabular}{|l|c|c|c|}
\hline & BCWP & BCWS & VARIANCE \\
\hline River Corridor Project & $\$ 60.5$ & $\$ 58.1$ & $\$ 2.4$ \\
\hline
\end{tabular}

The \$2.4 million (4 percent) favorable schedule variance is within the established threshold. Further information at the PBS level can be found in the following Schedule Variance Analyis details. 


\section{Fy 2000 Cost/SChedule Performance - All Fund Types Cumulative to Date Status - $(\$ 000)$}

F)(T)

By PBS

PBS TP()]

WBS 1.4 .1

Pl3S TP()4

W[3.S 1.4 .4

PI3S TPI2

WBS 1.46

PIBS 1PIO

WHS 148

PISSTPOP

WBSS 1.4 .10

PHS TPl4

WBS 1.4.11

\begin{abstract}
B-Plant
\end{abstract}
300 Area/ Special Nucleat

Materials

Transition Program

Management

Accelerated Deactivation

324:327 Facility I ransiı on

Hanford Surplus facility

Program (300)Area

Revitalization)

Iotal

\begin{tabular}{|c|c|c|c|c|c|c|c|c|c|c|}
\hline \multicolumn{2}{|c|}{ BCWS } & \multicolumn{2}{|c|}{ BCWP } & \multicolumn{2}{|c|}{$A(W P$} & \multicolumn{2}{|r|}{ SV } & $\%$ & $\mathrm{c} v$ & \multirow{2}{*}{$\begin{array}{l}\% \\
(1)^{\prime \prime}\end{array}$} \\
\hline$\$$ & 460 & & 160 & $\$$ & 575 & $\$$ & 0 & $\left(0^{\circ} \div 8\right.$ & $(115)$ & \\
\hline$\$$ & 3.278 & $\$$ & 3.252 & $\$$ & 2.876 & $\$$ & (26) & $-1 \% s$ & 376 & $12 \%$ \\
\hline$\$$ & 16.708 & $\$$ & 16.707 & $\$$ & 13.065 & $\$$ & (2) & $\left(0^{\circ} \circ \$\right.$ & $3.6,42$ & $22^{\circ} \circ$ \\
\hline$\$$ & 2.123 & $\$$ & 2.123 & $\$$ & 2.023 & $\$$ & (0) & $0 \% 8$ & 1100 & $5 \%$ \\
\hline$\$$ & 34.798 & $\$$ & 37.249 & 8 & 32.804 & $\$$ & 2.451 & $7 \% \$$ & 4,445 & $12^{\circ} \%$ \\
\hline$\$$ & 708 & $\$$ & 696 & $\$$ & 543 & $\$$ & (12) & $-2 \% 8$ & 153 & $220 \%$ \\
\hline$\$$ & 58.076 & $\$$ & 60.486 & $\$$ & 51.886 & $\$$ & 2,411 & $4 \% \$$ & 8.60100 & $14^{\prime}$ \\
\hline
\end{tabular}

Noles: RI - Disected costs (steam and laundry) are included in the Pl:M BCWS. Transition Project Management includes NMS portion of IPI? 310 11DP 340 Facility perfomlance data is reported under PBS WM05 (Waste Management)

\section{COST/SCHEDUle PeRformanCe Indices (MONTHLY AND FYTD)}

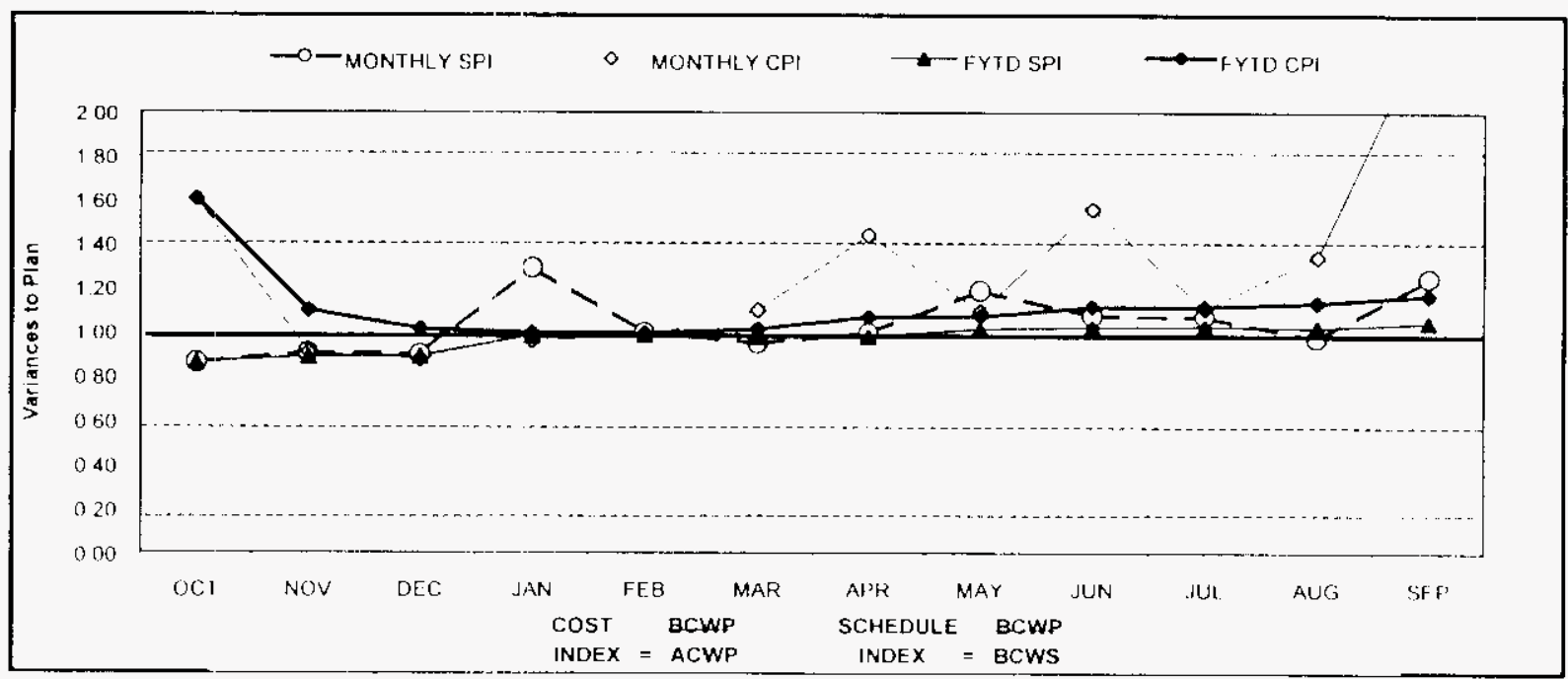

\begin{tabular}{|c|c|c|c|c|c|c|c|c|c|c|c|c|}
\hline Fr 2000 & $O C I$ & 201 & DEL & lis & $\mathrm{HEB}$ & $\operatorname{MlN}$ & Alek & $\mathbf{M A I}$ & Lx & | & ( & SEL \\
\hline 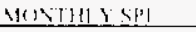 & i; 8,1 & $-1 \times 0$ & _- II (1) & 123 & 1 iti & $\ldots \quad(1)+4$ & (1) & 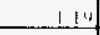 & 1117 & 107 & 11\%7 & 14 \\
\hline 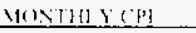 & $p(x, i)$ & $:(9)$ & [1:37 & 094 & {$[1,2 k$} & $(1,10$ & 14 & $1\{104$ & $i s 0$ & 111 & 134 & $\therefore 42$ \\
\hline FYTIOSPl] & $1+\mathrm{Kt}$ & 188 & (i);3) & (1) 08 & $=118$ & $\because 197$ & $(1), 3 \times$ & $1(1)$ & $11 \%$ & 1112 & $141=$ & 1134 \\
\hline HYLSB & isiv & $-1+1 ;$ & - 1111 & 20,913 & $\{1,2\}\}$ & (111) & 1,17 & 219 & 14 & -1.11 & $\perp \perp 3$ & 17 \\
\hline$\therefore O N I 11$ Y $B O W S$ & $5: 0.44$ & 5.58 & 8.4.08:2 & $\$ 3.355$ & Sin: & sings: & $354: 3$ & $8+1,0<1$ & 25,54 & $8.4, i(1.1)$ & 857 if & Sixix \\
\hline NGNIHLS HCWF" & $8: 11 !$ & Stint: & 83,051 & $54,9 ?:$ & 3.27761 & 85,85 & 552,80 & $57, x+4$ & $85+14$ & $5+1,(, 1)]$ & 15.5 .44 & $57,2=1$ \\
\hline AYSIIIL $16 \mathrm{WP}$ & 81.254 & $5:(4)$ & 5.1 .1 .15 & $552\left(1, t_{1}\right.$ & $24, i ; 7$ & $\$ 5135$ & 83,790 & 57.221 & $8,6,0,2,1$ & $\{4, \mid t, 1$ & 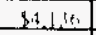 & $5: 11115$ \\
\hline IYTL BCWS & $8+2.14$ & $8 \times \times 07$ & $5: 804=$ & $5[6,75]$ & $\Sigma 21,14$ & $8 \div 7: 1: 1$ & $\sin 454$ & 530.1015 & 5.14 .36 .4 & $5+1 x+t+x+x$ & $59.4+41.4$ & $55811 \%$ \\
\hline $1 Y 113 \mathrm{BS} \mathrm{WP}^{3}$ & 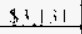 & $\$ 7,777$ & $5 ! 1 \pm \pm 1$ & S1 10.40 .1 .4 & $\{: 19,0,74$ & P.t. $\{(j)$ & $\$ 11,707$ & $S 34,(w)\}$ & $\$ 45.2 .45$ & $511 \times 4+1$ & $5 \leq 5+1$ & $\operatorname{sen}(x)+x_{n}$ \\
\hline W11 $10 \mathrm{kP}$ & $\leqslant 1,1 \leqslant 4$ & $5:(1+2 i$ & $\$ 1 ! 2: 1$ & $5 \mid 0,4+2) \mid$ & Sis: 201 & 1:50. & 826715 & $\sin , 9 s, k$ & Silis.4 & 1.7 .7 .45 & $\sin x x_{1}$ & $\$ \$ ! x \times t$ \\
\hline
\end{tabular}




\section{COST VARIANCE ANALYSIS: (+\$8.6M)}

\section{$\underline{\text { WBS/PBS }}$}

\subsection{4/ТP04}

\section{$\underline{\text { Title }}$}

\section{Area SNM}

$S \& M$ costs due to personnel working on other priority work related to I ranium Disposition. In addition, a favorable passback contributed to the variance.

Impact: None.

Corrective Action: Any underruns in funding were utilized to support super stretch activities and emerging work scope.

\subsubsection{0/ 08 324/327 Facility Transition}

Description and Cause: The favorable cost variance is from underruns in min safe 324 and 327 budgets and through work scope deletions and efficiencies.

Impact: None. Out year work scope was completed ahead of schedule.

Corrective Action: None.

\subsection{6/TP12 Transition Project Management}

Description and Cause: The favorable cost variance is primarily due to the Fluor Project Management Team re-structuring. which has mapped personnel from the sub-project to other sub-projects (i.e. Nuclear Material Stabilization), resulting in underruns in labor and contractor support.

Impact: None.

Corrective Action: None.

\subsubsection{1/TP14 HSFP 300 Area Revitalization}

Description and Cause: 'The favorable cost variance is primarily due to the receipt of favorable passbacks.

Impact: No impact.

Corrective Action: Any underruns in funding were utilized to support super stretch activities and emerging work scope.

All other PBS variances are within established thresholds.

\section{SCHEDULE VARIANCE ANALYSIS: (\$2.4M)}

All PBS variances are within established thresholds. 


\section{FUNDS MANAGEMENT \\ FUNDS V5 SPENDING FORECAST $(\$ 000)$ FY TO DATE THROUGH SEPTEMBER 2000 (FI.UOR HANFORD, INC. ONLY)}

\begin{tabular}{|c|c|c|c|c|c|c|c|c|c|}
\hline & \multicolumn{3}{|c|}{ Project Completion * } & \multicolumn{3}{|c|}{ Post $2(10)_{6}$ * } & \multicolumn{3}{|c|}{ 1.ine ltems : } \\
\hline & Funds & Actual Cost & Vinciance & Funds, & Actual cost & Veriancr & Funds & $\begin{array}{c}\text { Artual } \\
\text { Cost }\end{array}$ & Varisence \\
\hline \multicolumn{10}{|l|}{ The River } \\
\hline 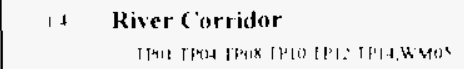 & $40,19 x$ & $4+4(1) 4$ & 1.72 .4 & 5168 & +323 & $x .95$ & & & \\
\hline Line $I t \mathrm{em}$ & & & & & & & 22 & 15 & 125 \\
\hline Jetal Biver Corrider Operating & $\$ 46.198$ & $\$ .44+404$ & $1.7+4$ & $\$ 508$ & $\$+3.323$ & 845 & & & \\
\hline Iotal Kiver Corrider Line Item & & & & & & & $\$ \quad 274$ & $\$ 154$ & 125 \\
\hline
\end{tabular}

* control Point

This reflects FH Project structure, which divides certain PBS's between projects (WM05 - WM and RCP. TP12 - RC'P and NMS). Consequently, these figures will differ from others reported elscwhere in this report (as gemerated in the PEM system).

\section{ISSUES}

\section{Technical Issues}

Issue: 324 Building - Iot spots on the bottom of Steel Waste Disposal Boxes (SWDBs) loaded with Rectangular Grout Containers are more radioactive than the current Central Waste Complex (C WC) acceptance criteria of one rem per hour.

Impacts: Shipment schedule/in-cell work schedule has been delayed.

Corrective Action: Pursuing several actions:

CWC evaluating an authorization basis change to allow increased dose rates. This may require shielding provided by 324 Building at CWC.

..- 32.4 Building evaluating SWDB loading to optimize sequence of individual items to minimize dose rates.

324 Building staffe evaluating "short loading" SWI blss to limit dose rates. Ihis will require purchase of adklitional SWDBS.

\section{DOE/Regulator/External Issues}

Issue: Approval by DOE-HQ of the Unirradiated Uranium (UU) billet Safety Analysis Report for Packaging (SARP). Revisior K. was requested by August 15, 2000, in order to make shipments during l:Y 2000 .

Impacts: I)( I-HQ has approved Revision $\mathrm{K}$ of the uranium billet Safety Analysis Report for Packaging ( $S$ ARP) with a Certificate of Compliance $(C O C)$ that allows shipment of only 3 billet boxes per trailer instead of the 5 boxes per trailer that was analyzed in the revision. Using this $(\mathrm{OC}$ will increase the billet transportation cost by approximately $\$ 200 \mathrm{~K}$.

Corrective Action: DOS-IIO has been informed of the impact. and a $(C)$ allowing five 
billet boxes per trailer is expected to be issued prior to shipment of the billets

Issue: An opportunity exists for transfer of PNNL. lacilities into TP-14. pending res. blution of the current IOOE-HQ guidance to EM (pipelin suspension). PNNI, has funds for IY $200120(02$ Surveillance and Maintenance (S\&M) identified for transfer to lit but these funds may no longer be available when the suspension ends.

Impacts: I:fficiencies realized through combining these facilities into TP- 1 it may be jeopardized.

Corrective Action: PNNI, has drafted a Memorandum of Agreement (MOA) to detine a path forward and mechanism for doing business while lll performs necessary assessments to estimate surveillance and maintenance costs for the buildings that are being considered for transfer. Initial response received from internal review of this $\mathrm{M}(\mathrm{A} A$ is favorable. $\mathrm{FH}$ is continuing to gather information regarding out-year funding sources.

\section{Baseline Change Requests Currently in Process $(\$ 000)$}

\begin{tabular}{|c|c|c|c|c|c|c|c|c|c|}
\hline $\begin{array}{l}\text { PROJECT } \\
\text { CHANGE } \\
\text { NUMBER } \\
\end{array}$ & $\begin{array}{l}\text { DATE: } \\
\text { OBIGILi. }\end{array}$ & BCR TULL & $\begin{array}{c}\text { FYOO COSI } \\
\text { IMPACI } \\
\text { S000 } \\
\end{array}$ & $\begin{array}{l}5 \\
6 \\
H\end{array}$ & $\begin{array}{l}1 \\
\text { E } \\
\text { C } \\
\text { 1) }\end{array}$ & $\begin{array}{c}\text { DATE TO } \\
\mathrm{CCB}\end{array}$ & $\begin{array}{c}\text { COB } \\
\text { ANR'L }\end{array}$ & $\begin{array}{c}\text { RL. } \\
\text { IPR'YD } \\
\end{array}$ & $\begin{array}{c}\text { (IRRFNI } \\
\text { SIULS' }\end{array}$ \\
\hline $\mathrm{FSP}^{3}-()(0-0)(02$ & $11 / 2 / 99$ & Mark-42 Project Completion & $\$ 0$ & & $\mathrm{x}$ & $0405 / 00$ & & & $\begin{array}{l}\text { Addt'l tumdme } \\
\text { rey'd }\end{array}$ \\
\hline$f S I^{\prime}-2000(0)-108$ & $7 / 20 / 0(0$ & 224-T Characterization & $\$ 180$ & & $x$ & $\mathrm{~N} / \mathrm{A}$ & VA & $\mathrm{N} / \mathrm{A}$ & ( incelled \\
\hline SSP-2000(1-072 & $7 / 27 / 00)$ & MYWP Submittal (I'hase I) & $\$ 0$ & $x$ & $\mathrm{x}$ & $08: 2500$ & & 083100 & $\begin{array}{l}\text { Pending RI. } \\
\text { Appor: }\end{array}$ \\
\hline $\mathrm{F} S \mathrm{SP}-2000(0-(1) 75$ & $8 / 3 / 00$ & Uraniun I)isposition Project & $\$ 400$ & & $x$ & $09 / 1300$ & & $09 / 13 / 00$ & Approsed \\
\hline $\mathrm{FSP}-20000-077$ & $8 / 8 / 00$ & Install Back-Flow Prevention & $\$ 0$ & & $x$ & $08 / 2900$ & & $N A$ & Withdratin \\
\hline FSP-20(0)-080 & $8 / 15 / 00$ & Defer 324 Building Scope & $-\$ 487$ & $x$ & $x$ & $08 / 28 / 00$ & & $09 / 11 / 00$ & Approwed \\
\hline$\left[: \mathrm{S}^{\prime}-20()(0-0) 8 !\right.$ & $8 / 1500$ & $\begin{array}{l}\text { Add Award tee } B C \text { WS for } \\
\text { Stretch (ioal Workscope }\end{array}$ & $\$ 450$ & & & $0905 / 00$ & & $09: 11 / 00$ & Approsed \\
\hline $1 S S P-2000-1182$ & $8 / 16 / 00$ & Delete 324 building Scope & $-\$ 115$ & $x$ & $x$ & $08 / 28 / 00$ & & $09 / 1100$ & Approsed \\
\hline $1: S P^{3}-20000-083$ & $8: 30 / 00$ & $\begin{array}{l}\text { I elete } 300 \text { Area } A\left(\mathrm{P}^{\prime}\right. \\
\text { levelopment from } \mathrm{TP}^{\prime} 14\end{array}$ & $-\$ 2.170$ & & & $0900500)$ & & $(0) \cdot 11: 00$ & Apprased \\
\hline $\mathrm{J}: \mathrm{SP}^{\prime}-20(0)-08+$ & $8 / 31 / 00$ & Iransfer 2091 f facility & $\$ 0$ & & $x$ & $09: 1400$ & & $0914 \% 0$ & $\begin{array}{l}\text { Pending RI } \\
\text { Apromal }\end{array}$ \\
\hline$[11-20(0)-001$ & $1 / 12 / 00$ & $\begin{array}{l}\text { l3ase Opi Reduction for PIMC } \\
\text { l'rojects }\end{array}$ & $-\$ 3.26 .3$ & & $x$ & & & & Drati Prepared \\
\hline $\mathrm{Fin}-20(0)-()(0)$ & $9 / 25000$ & FY2001 fee Reduction $1090 \%$ & $-\$ 413$ & & & & & & I tatt l'repared \\
\hline 1$] 1-2001-(0) 3$ & $9 / 25 / 00$ & $\begin{array}{l}\text { f:Y } 2001 \text { Addition of High } \\
\text { Priority Workicope }\end{array}$ & $\$ 14.951$ & & $x$ & & & & Irate Prepared \\
\hline \multicolumn{10}{|c|}{ ADVANCE WORK AITHORIY ITIONS } \\
\hline AWA & $10 / 2 / 00$ & FYol I!ranium [Disposition Act & $\$ 371$ & & $\mathrm{X}$ & $10: 3: 00$ & & & \\
\hline
\end{tabular}


PHMC Environmental Management Performance Report - November $2000, x_{1} x_{x} x_{x}$

Section C: 2 - River Corridor

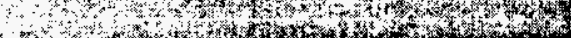

Milestone ACHieVement

\begin{tabular}{|c|c|c|c|c|c|c|c|c|}
\hline \multirow[b]{2}{*}{ MILESTONE TYPE } & \multicolumn{4}{|c|}{ FISCAL YEAR-TO-DATE } & \multicolumn{3}{|c|}{ REMAINING SCHEDULED } & \multirow[b]{2}{*}{$\begin{array}{c}\text { TOTAL } \\
\text { FY } \\
2000\end{array}$} \\
\hline & $\begin{array}{c}\text { Completed } \\
\text { Early }\end{array}$ & $\begin{array}{c}\text { Completed on } \\
\text { Schedule }\end{array}$ & $\begin{array}{l}\text { Completed } \\
\text { Late }\end{array}$ & Overdue & $\begin{array}{c}\text { Forecast } \\
\text { Early }\end{array}$ & $\begin{array}{l}\text { Forecast } \\
\text { On } \\
\text { Schedule }\end{array}$ & $\begin{array}{c}\text { Forecast } \\
\text { Late }\end{array}$ & \\
\hline Enforceable Agreement & 1 & 0 & 0 & 0 & 0 & 0 & 0 & \\
\hline DOE-HQ & c & 0 & 0 & 0 & 0 & 0 & 0 & \\
\hline $\mathrm{RL}$ & 2 & 1 & 0 & 1 & 0 & 0 & 0 & 4 \\
\hline Total Project & 3 & 1 & 0 & 1 & 0 & 0 & 0 & 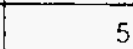 \\
\hline
\end{tabular}

Only TPA/EA milestones and all FY 2000 overdue and forecast late milestones are addressed in this report. Milestones overdue are deleted from the Milestone lixception Report once they are completed. The following chart summarizes the FY 2000 TPA/LA milestone achievement and a Milestone Exception Report follows. The last milestone table summarizes the first six months of FY 2001 TPA/EA milestones.

\begin{tabular}{|l|l|l|}
\hline \multicolumn{3}{|c|}{ FY 2001 Tri-Party Agreement / EA Milestones } \\
\hline $\begin{array}{l}\text { M-92-13 } \\
\text { (TRP-00-902) }\end{array}$ & $\begin{array}{l}\text { "Submit 300 Area SCW Project } \\
\text { Management Plan to Ecology Pursuant to } \\
\text { Agreement Action Plan Section 11.5," due } \\
9 / 29 / 00\end{array}$ & $\begin{array}{l}\text { Completed 6 months carly } \\
(3 / 28 / 00)\end{array}$ \\
$\begin{array}{l}\text { M-92-14 } \\
\text { (1RP-02-901) }\end{array}$ & $\begin{array}{l}\text { "Complete Removal of Phase I 300 Area } \\
\text { Special Case Waste and Materials," due } \\
9 / 30 / 02\end{array}$ & $\begin{array}{l}\text { Completed 30 months } \\
\text { carly }(03 / 28 / 00) \text { pending } \\
\text { acceptance of the plan by } \\
\text { Ecology. }\end{array}$ \\
\hline \multicolumn{2}{|c|}{ DNFSB Commitments } \\
\hline
\end{tabular}

MILESTONE EXCEPTION REPORT

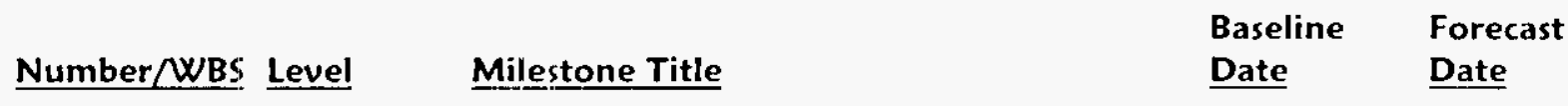

\section{OVERDUE - 1}

TRP-99-933 RI, ('ontainerize Dispersible Under $2 A$ Rack $\quad 04 / 30 / 00$ 11/24/00)

\subsubsection{0}

Cause: It has been determined it is more efficient to complete dispersible collection once size reduction of miscellaneous items is completed.

Impact: No impact. This milestone will complete with M-89-02.

Corrective Action: No corrective action is required.

FORECAST LATE - 0 


\begin{tabular}{|l|l|l|}
\hline \multicolumn{3}{|c|}{ FY 2001 Tri-Party Agreement / EA Milestones } \\
\hline $\begin{array}{l}\text { M-89-02 } \\
\text { (TRP-99-901), }\end{array}$ & $\begin{array}{l}\text { "Complere: Removal of 324 Building } \\
\text { Radiochemical Engineering Cells } \\
\text { (REC) B Cell Mixed Waste (MW) and } \\
\text { Equipment," }\end{array}$ & $\begin{array}{l}\text { Due 11/30/00 - Work lowards } \\
\text { completion of M-89-(12 is 21 } \\
\text { days behind } \\
\text { schedule. }\end{array}$ \\
\hline & \multicolumn{3}{|c|}{ DNFSB Commitments } \\
\hline & Nothing to report. \\
\hline & PERFORMANCE OBJECTIVES
\end{tabular}

\begin{tabular}{|c|c|c|}
\hline Outcome & Performance Indicator & Status \\
\hline \multirow{5}{*}{$\begin{array}{l}\text { Restore } \\
\text { the River } \\
\text { Corridor } \\
\text { for } \\
\text { Multiple } \\
\text { Uses }\end{array}$} & $\begin{array}{l}\text { FDH-RC-2 } \\
\text { Accelerate } 324 / 327 \text { Deactivation. }\end{array}$ & $\begin{array}{l}\text { Current } 1 \text { ife Cycle Schedule ariance } 1.14^{\circ} \text { and I ife } \\
\text { Cycle Cost Variance } 1.9^{\circ} \text { o. I otal float is at } 72 \text { days } \\
\text { RCP believes that PI RC-2 was accomplished. }\end{array}$ \\
\hline & $\begin{array}{l}\text { FDH-RC-2SS } \\
\text { Continue Acceleration of } 324 / 327 \\
\text { Deactivation - Complete } 327 \text { Facility } \\
\text { accelerated deactivation activities by } \\
\text { September } 2000 \text {. }\end{array}$ & $\begin{array}{l}\text { Completed shipment of } 103 \text { legacy buckets, } 474.7 \text { grams } \\
\text { of fissile material, } 32.5 \mathrm{~m} \text { ' of bulh waste, } 8 \text { fuel pins as } \\
\text { well as cleanout of } \mathrm{H} \text { Cell. This accelerated workscope } \\
\text { accomplishes } 80^{\circ} \text { of the expectations tor this super- } \\
\text { stretch Pl. }\end{array}$ \\
\hline & $\begin{array}{l}\text { FDH-RC-3SS } \\
\text { Disposition Uranium Complete: disposition of } \\
\text { 186.5 Metric Tons (MT) of Hanford } \\
\text { Uransum by September } 2000 .\end{array}$ & 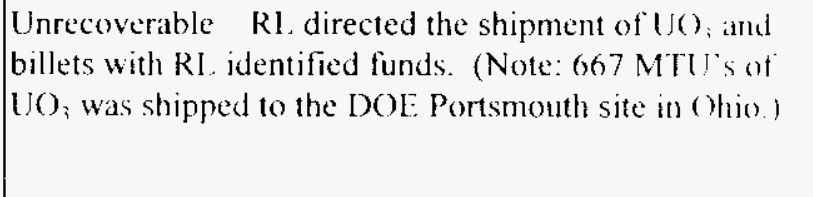 \\
\hline & $\begin{array}{l}\text { FDH-RC-5SS } \\
\text { Accelerate } 300 \text { Area Closure Project. }\end{array}$ & $\begin{array}{l}\text { Plan issued June } 30,2000 \text {. Feedback received in } 1)() \mathrm{l} \\
\text { Executive Evaluation Report is positive. R(P helieves } \\
\text { that PI RC-5SS was accomplished. }\end{array}$ \\
\hline & $\begin{array}{l}\text { FDH-RC-5SS-2 } \\
\text { Accelerate Cleanup of zone } 4 \text { of } 300 \text { Area. }\end{array}$ & $\begin{array}{l}\text { Unrecoverable No funds identified to support } \\
\text { completion of plysical work. }\end{array}$ \\
\hline Multiple & Comprehensive performance & $\begin{array}{l}\text { All baseline work projected to be complete per Pl } \\
\text { requirements. Additionally, NHDI performance for the } \\
\text { year has met or exceeded the Comprehensive Pl eriteria. }\end{array}$ \\
\hline
\end{tabular}

\section{KEY INTEGRATION ACTIVITIES}

- National Facility Deactivation Initiative (NFDI) Support to DOE Complex - In FY 2000 implementation of NFDI DOE-complex objectives was completed. Key accomplishments included a deactivation plan for Savannah River Site's I: Canyon: evaluation of buildings for transfer into DOE:-LM at $\mathrm{k}$ Ridge, Pantex, and hanford: stabilization assistance for Brookhaven's High Flux Beam Reactor; and deactivation assistance for facilities at INEEL, Nevada Test Site and l lanford's 300 Area. 
- 324 SNF Project Savings -- In FY 2000 the River corridor Project (Re 'P) 324 Building B (ell project, along with the Spent Nuclear Fuel Project (SNF), developed an alternative plan for the fuel removal activity. Agreement to use a longer inner canister for the fuel permits greater end shielding and allows manual welding and testing in the ('ask llandling Area (CHA). rather than the more expensive remote effort in B (ell. The Programmatic Agreement, which outlines the responsibilities and general items for this fuel transfer. was approved by both RCP anc $\$ \mathrm{NF}$ on ()etober 6, 2000. The 200 Area Interim Storage Area Aceeptance (riteria (HNF.4894) is undergoing final review and comment by R( $P$. Comments will be forwarded to SNF and the revised document is expected about November 30,2000 .

- EM-50 Support - With support from EM-50. Al:A Technology has completed two draft reports in FY 2000 which support future RCP deactivation tasks: (1) (Iption Study for Inspection. Sampling and Remediation for Tank T-105 in the /lLW Wault in Building at Hanford: and (2) Options study for B ('ell HVAC'Duct Remediation. Final reports should be issued within the next month. Other topics proposed by RCP for 2001 funding are:

- Demonstration and Deployment of the AVA Artisan-100 Arm for Hot Cell Deactivation

- Options Study on Intact Removal and Disposal of 327 Facility Hot Cells

- Dry Decontamination of 327 lot Cells

- 340 Vault Tank Heel Removal

IOOE-HO is in the process of prioritizing all projects suggested for assignment to ALA

Technology. RC P has received preliminary indications that the funding/support to the Tank $1-105$ and HVAC Duct Remediation tasks will be supported in FY 2001.

- New llanford-Rocky Flats-Savannah River Joint Deactivation Proposal - Through involvement with NFDI, Hanford. Rocky Flats, and Savannah River completed and submitted in FY 2000, a joirt proposal focused on demonstration and deployment of large équipment size reduction systems.

- Participation in West Valley Demonstration Project - In F Y 2000 RCP issued a letter of support to DOE-RL to participate as a "non-host deployment site" in a proposal led by PNNI. Technology Development and West Valley. The West Valley (NY) Demonstration Project is deactivating hot cell facilities with similar decontamination and decommissioning challenges to RC'P facilities. The project would fund FII on an Integrated contractor Ieam (ICT). The IC"I will influence the identification and selection of technologies. Based on successful demonstration at West Valley, FH will consider the best technologies for use at RCP. Nine proposals from throughout the DOE-Complex were submitted in response to EM-50's Large Scale Demonstration and Jeployment Program call for proposals, with III involvement in three of the nine. 


\section{Building Deactivation}

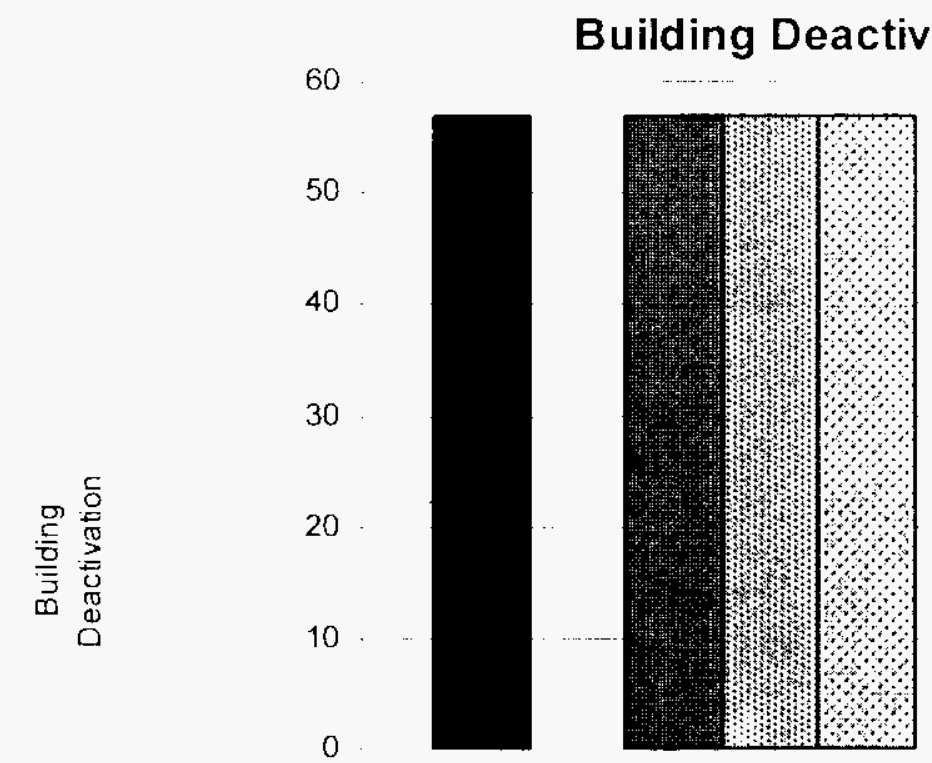

Bldg. Not Yet Deactivated
Post Deactivation

$\begin{array}{cc}57 & 2 \\ 0 & 2 \\ 57 & 2 \\ 57 & 2 \\ 57 & 2\end{array}$

Buildings Not Yet Deactivated: Current approved budget does not fund building deactivation in the 300 area. Therefore, plans for deactivation have been deferred to FY20()2.

Post Deactivation: These are two storage building to be turned over to BHIl when the 324/327 Transition Project is completed in FY 2007. 

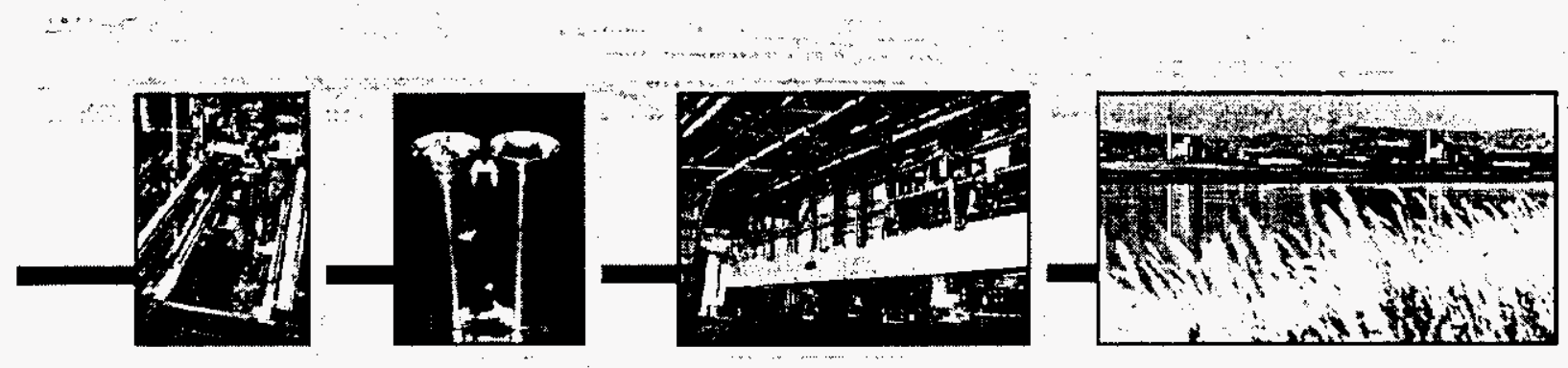

\section{Section D}

Spent Nuclear Fuel

PROJECT MANAGERS

P.G. Loscoe, RL (509) 373-7465

J.H. Wicks Jr., FH (509) 373-9372 


\section{SUMMARY}

The Spent Nuclear Fuel (SNF) mission consists of the Spent Nuclear Fuel Project W BSS 1.3.1.1 (Project Baseline Summary [PBS] WMO1) and the subsequent Canister Storage Building (CSB) Operations Project WBS 1.3.2.1 (PBS WM02), which does not start until FY 2004.

NOTE: Unless otherwise noted, the Safety, Conduct of ( )perations. Milestone Achievement, and Cost/Schedule data contained herein is as of September 30.2000. All other information is as of October 19,2000.

\section{Top 5 Accomplishments for FY 2000}

Phased Startup Initiative (PSI) - Implemented a strategy to conduct carly testing of the K West (KW) Fuel Retrieval System (FRS) and the Integrated Water Treatment System (IWTS). This reduced the schedule risk to fuel movement from $\mathrm{KW}$ basin by validating the fuel cleaning process. provided early identification of problems to provide maximize time available for correction, and accelerated personnel training and procedure preparation to maximize readiness preparations. Results from the PSI are expected to improve the fuel production rates in IVY 2001 (Progress).

Sludge Strategy - Successfully implemented a Baseline ('hange Request, which accelerates the completion of sludge removal by one year from August 2005 to August 2004 and reduces total project life cycle cost by $\$ 16$ million (Momentum).

Construction Projects - Completed construction and testing on 2 facilities; Canister Storage Building (CSB) and Cold Vacuum Drying Facility (CVI)F). These facilities were subsequently turned over to the Operations organizations. Also completed major renovations on KW Basin in preparation for fuel movement activities. Completed construction of the Interim Storage Area (ISA) adjacent to the CSB to facilitate storage of Hanford Site SNF on 200 Area Plateau (Progress).

Safety - The SNI Project twice achieved one million safe nianhours worked during a time when construction was at a peak (Progress).

SNF Storage Projects - Completed integrated testing of the Cask Transport System (C"IS) with other key components of the fuel-removal process and formally turned over to CSB (Operations. Fabrication and lesting activities for MCOs continues. To date a total of 38 MC ( ) s have been delivered ahead of schedule. Fabrication of the MCO haskets continues at the 328 shop at the Hanford Site. Assembly is complete on 216 Mark 1 A baskets (with the exception of the outside posts). Delivery of the completed baskets is expected in I ecember 2000 (Progress). 


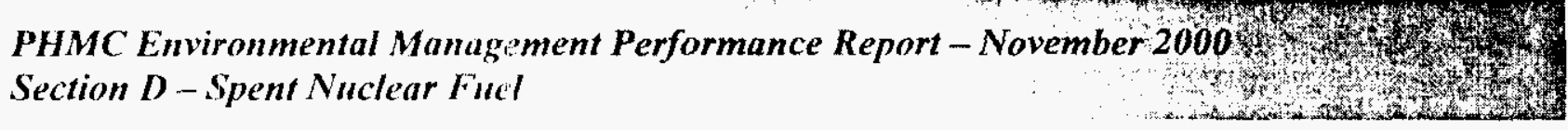

Additional FY 2000 Accomplishments

\section{Progress}

Safety Analysis Documentation - Obtained D( )l approval of over 4.000 pages of safety documentation crucial to Project operations, including final safety analyses for the ('anister Storage Building (CSB), the ('old Vacuum Drying Facility ( 'VDF'), work in the $\mathrm{K}$ Basins, and Project transportation systems. Authorization basis documents have been implemented for CSB, CVDF, and Project transportation systems.

HANSF analysis tool - The HANSF analysis tool has been used effectively to consider a wide variety of phenomena inside a Multi-Canister Overpack such as fuel oxide type, convective and radiant heat transfer, and the potential for fission product release.

Fiscal year-to-date milestone performance (EA, DOE-HQ. and RI) shows that three out of five milestones (60) percent) were completed on or ahead of schedule, one RL milestone (20 percent) was completed late and one RI. milestone $(20$ percent) is overdue.

The Milestone Achievement details, found following the cost and schedule variance analysis. provide further information on all milestone types.

\section{Accomplishments this Reporting Period}

- Successfully completed Contractor Operations Readiness Review (ORR) on CSB, K West Basin, and Project transporation systems.

- Commenced Contractor ORR for the CVDE.

- Completed cold testing in the $\mathrm{K}$ West Basin with pieces of pipe designed to resemble irradiated, or spent, fuel.

- Initiated hot testing on September 30 by decapping a select number of actual canisters containing spent fuel, washing the fuel, and sorting the fuel utilizing the fuel Retrieval System (FRS) and the Integrated Water Treatment System (IWTS).

- Began DOE (Operational Raadiness Review.

\section{SAFETY}

The project has achieved over 1,800,000 safe work hours, and no Lost Away Workday Cases have been reported in the last eleven months. The number of safe hours has significantly improved over J:Y 1999. Although the SNF Project experienced some safety performance degradations with the start of FY 2000, performance continues to improve.

Two OSHA cases in July raised the trend above the average. The project continues to monitor the rising trend over the last four month. However, the case rate has improved 25 percent in FY 2000 over FY 1999.

The past fifteen of seventeen months for the I)OF Cost Index have been below average. 


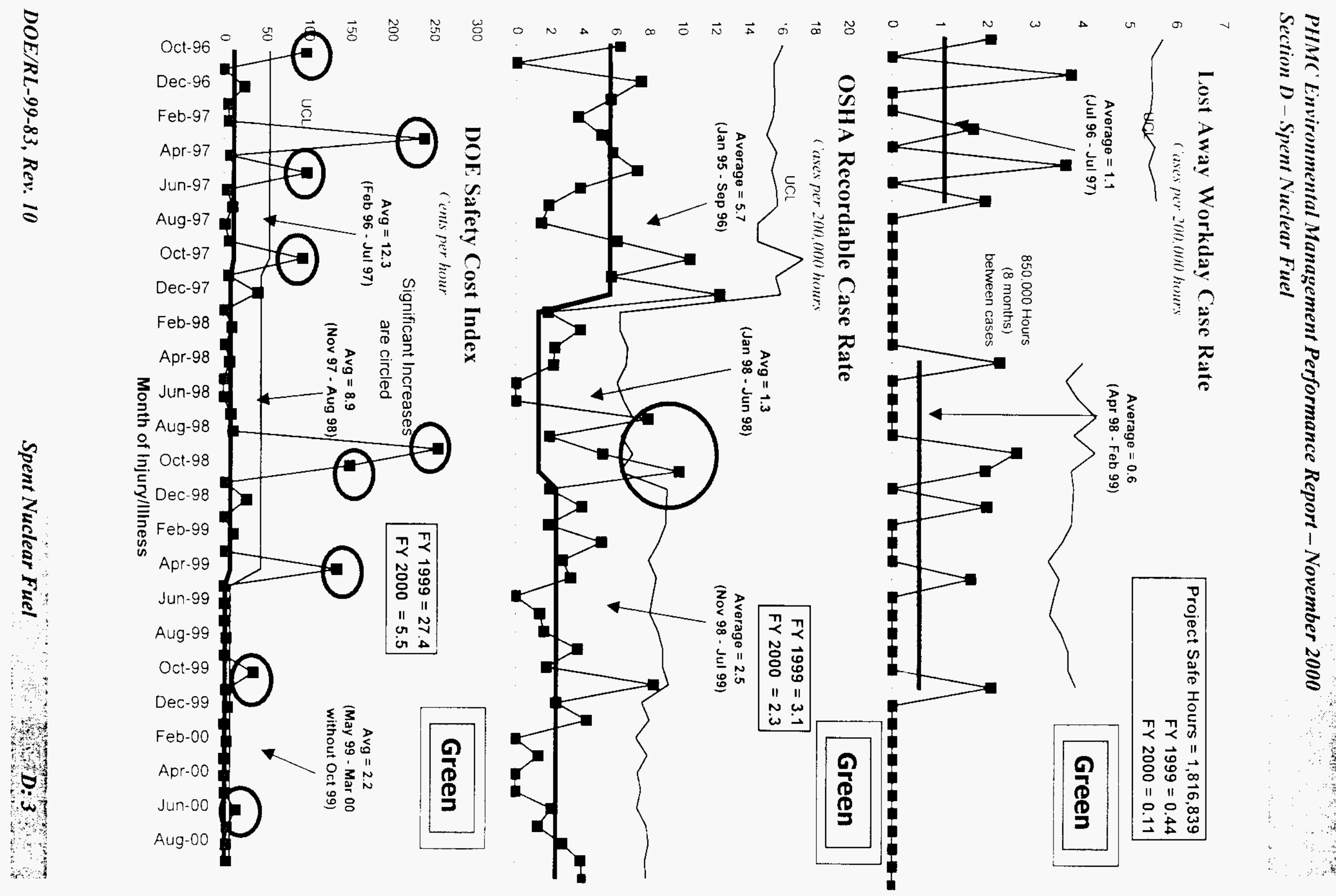




\section{CONDUCT OF OPERATIONS / ISMS STATUS}

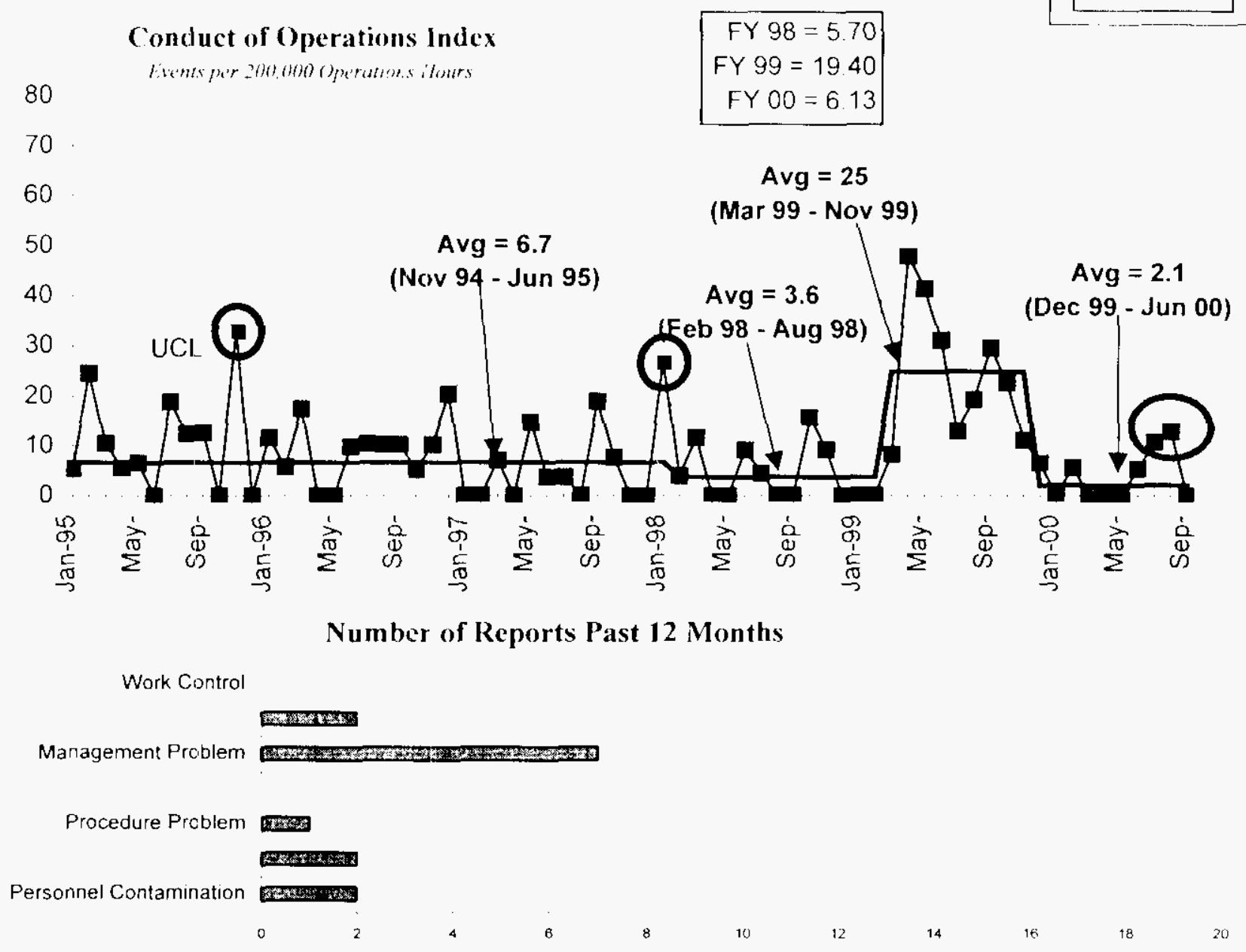

From June through September, there were six Conduct of Operations incidents reported: four Management Problems, one I.cek and Tag, and one Procedure Problem.

\section{ISMS STATUS}

\section{Green}

- The Integrated Safety Management System (ISMS) Phase I/II verification for the SNF Project was completed on November 19, 1999.

- The Corrective Action Plans for the "Opportunities for Improvement" were developed and transmitted to RI, on January 10.2000.

- The actions required to enable ISMS implementation to be declared March 31, 2000 are complete. Documentation packages were transmitted to the Environmental, Safety and Health organization. Three of the four packages were reviewed as part of the Project I Hanford Management Contract (PHMC) Phase I verification. These items are now complete. The one remaining item needing RI, verification (dealing with Chemical Management Implementation) was reviewed by RI, on August 11, 2000. 
()n September 72000 , FI received a letter from Keith Klein, D) ()L-RI indicating all corrective action :ckages were sufficient and considered closed. The letter stated. "FIII can now conside ine ISMS verification suceessfully completed."

\section{BREAKTHROUGHS / OPPORTUNITIES FOR IMPROVEMENT}

\section{Breakthroughs}

\section{Green}

Baseline Change Request SNF-2000-009, which documents acceleration of the completion of sludge removal by one year from August 2005 to August 2004 and reduction in total project lifi cycle cost by $\$ 16$ million, was implemented.

\section{Opportunities for Improvement}

Operational Readiness Review Sequence - In collaboration with DOE. FH has developed a sequenced ORR process. The initial contractor ORR commenced September 28 covering KW Basin, CSB and CTS. The second contractor ORR kickoff was October 17 at the (YI). In parallel, the DOE ORR starts at KW, CSB and CTS in November.

\section{UPCOMING ACTIVITIES}

- Complete Contractor Operational Readiness Review in October 2000.

- Continue receipt of MCO shipments.

- K Basins Projects

- Begin $\mathrm{K}$ West Basin fuel removal drying and storage operations in November 2000$)$

- Complete K East Basin Sludge Loadout conceptual design January 2001.

- Complete K Last Basin IWTS definitive design April 2001.

- Initiate K West Basin canister cleaning December 2000 .

- Submit Annual Debris Report to Department of ficology/IPA in May 2001 


\section{Cost Performance (\$M):}

\begin{tabular}{|l|c|c|c|}
\hline & BCWP & ACWP & VARIANCE \\
\hline Spent Nuclear Fuel & $\$ 198.2$ & $\$ 201.7$ & $-\$ 3.5$ \\
\hline
\end{tabular}

The unfavorable cost variance of $\$ 3.5$ million (2 pereent) is primarily due to Hanford Site assessments higher than baseline and additional facility start up and engineering required as a result of tirst-of-a-kind equipment issues at K Basins and the ('VI) Facility.

\section{SChedule Performance ( $\$ M)$ :}

\begin{tabular}{|l|l|l|c|}
\hline & BCWP & BCWS & VARIANCE \\
\hline Spent Nuclear Fuel & $\$ 198.2$ & $\$ 201.8$ & $-\$ 3.6$ \\
\hline
\end{tabular}

The unfavorable schedule variance of $\$ 3.6$ million ( 2 percent) is primarily a result of the following: fabrication and installation of the KE: floor sludge retrieval system postponed until $\mathrm{I} Y \mathrm{YO}$; the $\mathrm{KW}$ canister cleaning work scope has been placed on hold pending a path forward decision; Kl: IWTS design behind schedule due to rebid for competitive price evaluation and integrated sludge/fuel strategy: and the procurements of the ( SB impact absorbers and some MCO plugs have been postponed until FYOI.

\section{FY 2000 Cost/SC.hedule Performance - All Fund Types Cumulative to Date Status - (\$000)}

By PBS

PBS WM(0) Spent Nuclear

WBS I., Fuel Project

Total
FYTD

\begin{tabular}{lllllll}
\hline BCWS & BCWP & ACWP & SV & $\%$ & CV & $\%$
\end{tabular}

Authorized baseline as per the Integrated Planning Accountability, and Budget System (IPABS) Project lixeculion Module (PI:M) 


\section{Cost/SChedule Performance Indices (MONTHLY AND FYTD)}

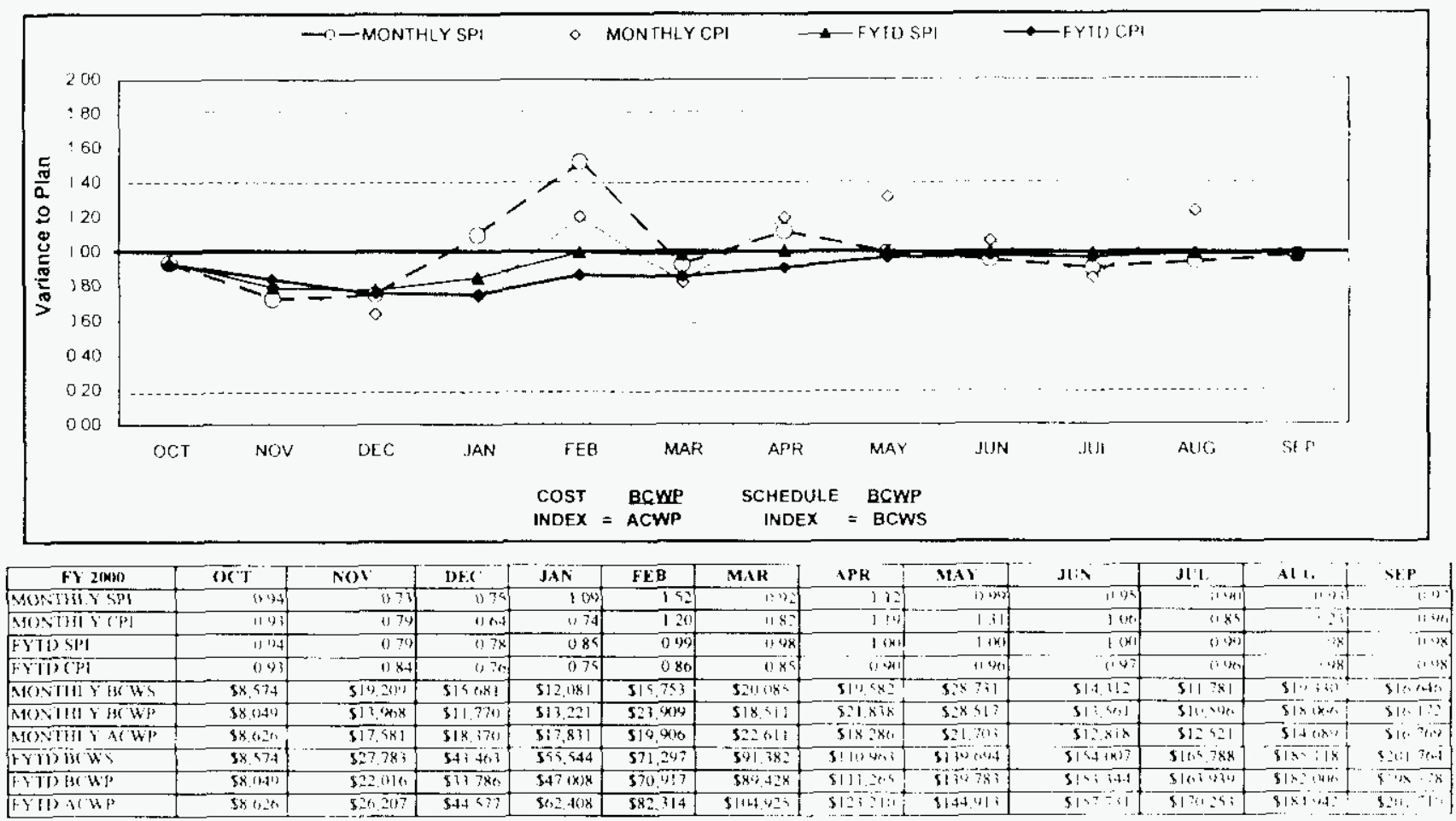

\section{Cost Variance Analysis: $(-\$ 3.5 \mathrm{M})$}

WBS/PBS

1.3.1/WM01

\section{Title}

Spent Nuclear Fucl Project

Description/Cause: Ended fiscal year 2000 within threshold.

Impact: Nonc.

Corrective Action: None.

\section{SCHEDULE VARIANCE ANALYSIS: (- \$3.6M)}

\section{WBS/PBS}

\section{Title}

1.3.1/ WM01

Spent Nuclear Fuel Project

Description /Cause: Ended fiscal year 2000 within threshold.

Impact: None.

Corrective Action: None

\section{:}




\section{FUNDS MANAGEMENT FUNDS VS SPENDING FORECAST $(\$ 000)$ FY TO DATE THROUGH SEPTEMBER 2000 (FI.UOR HANFORD, INC. ONLY)}

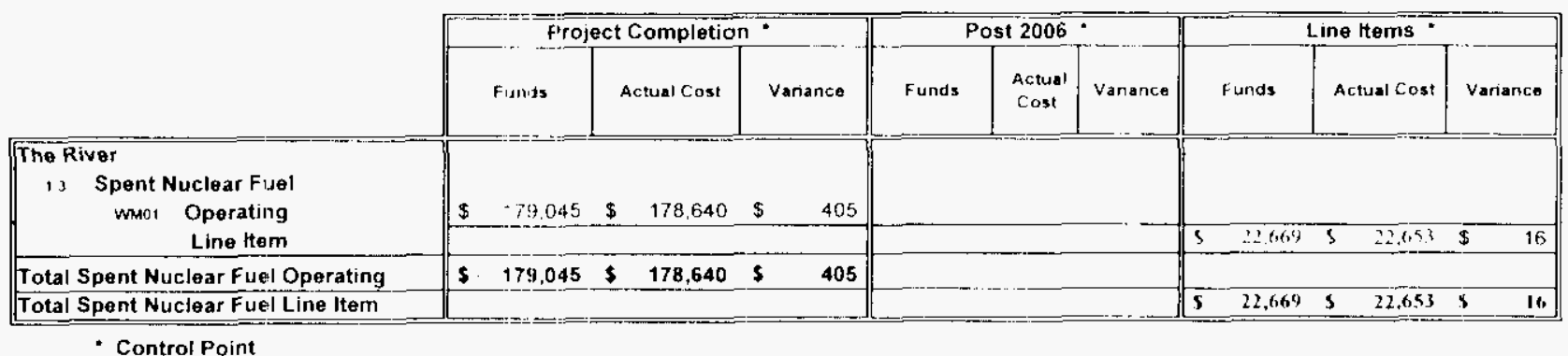

Above chart reflects FH Project structure, which divides certain PBS's between projects (e.g., TP12 - NMS and the River Corridor project). Consequently. these figures may differ from those shown elsewhere in this report (as generated in the PEM system).

None.

\section{Baseline Change Requests Currently in Process (\$000)}

\section{Green}

\begin{tabular}{|c|c|c|c|c|c|c|c|c|c|}
\hline $\begin{array}{l}\text { PROJECT } \\
\text { CHANGE } \\
\text { NUMBER }\end{array}$ & $\begin{array}{l}\text { DATE } \\
\text { ORIGIN. }\end{array}$ & BCR TITLE & $\begin{array}{l}\text { FYOO COST } \\
\text { IMPACT \$O00 }\end{array}$ & $\begin{array}{ll} & \\
& \\
c & \\
H\end{array}$ & $\left.\begin{array}{l}T \\
E \\
C \\
H\end{array}\right]$. & $\begin{array}{l}\text { DATE } \\
\text { TO CCB }\end{array}$ & $\begin{array}{c}\text { CCB } \\
\text { APR'VD } \\
\end{array}$ & $\begin{array}{c}\text { RL } \\
\text { APR'VD } \\
\end{array}$ & $\begin{array}{c}\text { CURRENT } \\
\text { STATUS } \\
\end{array}$ \\
\hline $\mathrm{NI}-2(t)(t)-(1) \mathrm{l}$ & $5 / 3 /(x)$ & $\begin{array}{l}\text { FRS.IW IS Phased Sitiatup } \\
\text { Imuthat lave - Adding Ilol lestng }\end{array}$ & $\$ 2.816$ & $Y$ & 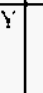 & $8 / 21 /(1 /)$ & $8 / 24(x)$ & $1 / 17 \%(1)$ & Appresed \\
\hline$S N \mid-2(H)(n-1)=21$ & $7 / 27: 010$ & 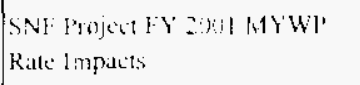 & & Y) & y & $8: 1 /(t)$ & $8 / 301(x)$ & $1 / 219:(k)$ & \\
\hline $1712(t) 11-(4) 2$ & $1925(k)$ & FY Yan Fee Reduct.me $1090^{\circ}$ & $-\$ 1,0360$ & & & & & & IItalt Prepared \\
\hline \multicolumn{10}{|c|}{ GDVAVC WOKK AITHIORLATIONS } \\
\hline & & Wenthinet to repart at the tume & & & & & & & \\
\hline
\end{tabular}




\section{Milestone ACHievement}

\begin{tabular}{|c|c|c|c|c|c|c|c|c|}
\hline \multirow[b]{2}{*}{ MILES TONE TYPE } & \multicolumn{4}{|c|}{ FISCAL YEAR-TO-DATE } & \multicolumn{3}{|c|}{ REMAINING SCHEDULED } & \multirow[b]{2}{*}{$\begin{array}{c}\text { TOTAL } \\
\text { FY } \\
2000\end{array}$} \\
\hline & $\begin{array}{c}\text { Completed } \\
\text { Early }\end{array}$ & $\begin{array}{c}\text { Completed } \\
\text { On } \\
\text { Schedule }\end{array}$ & $\begin{array}{l}\text { Completed } \\
\text { Late }\end{array}$ & Overdue & $\begin{array}{c}\text { Forecast } \\
\text { Early }\end{array}$ & $\begin{array}{c}\text { Forecast } \\
\text { On } \\
\text { Schedule }\end{array}$ & $\begin{array}{c}\text { Forecast } \\
\text { Late }\end{array}$ & \\
\hline Enforceable Agreement & $T$ & $\pi$ & of & 0 & 0 & 0 & 0 & 2 \\
\hline DOE-HQ & 0 & o & of & 0 & 0 & 0 & 0 & 0 \\
\hline$R L$ & 1 & 0 & 1 & 1 & o & 0 & o & 3 \\
\hline Total Project & 2 & 1 & 1 & 1 & 0 & 0 & 0 & 5 \\
\hline
\end{tabular}

Only TPA/EA milestones and all FY2000 overdue and forecast late milestones are addressed in this report. Milestones overdue are deleted from the Milestone Exception Report once they are completed. The following chart summarizes the FY2000 TPA/EA milestone achievement and a Milestone Ixception Report follows. The last milestone table summarizes the first six months of FY2001 TP $N / E A$ milestones.

STATUS AS OF $9 / 30 / 2000$

FY 2000 Tri-Party Agreement / EA Milestones

\begin{tabular}{|c|c|c|}
\hline Number & Milestone Title & Status \\
\hline $\begin{array}{l}\text { M-34-14A } \\
(\mathrm{S} 06-97-009)\end{array}$ & $\begin{array}{l}\text { "Complete K West Basin Cask Facility } \\
\text { Modifications" }\end{array}$ & $\begin{array}{l}\text { Due } 2 / 29 / 00 \\
\text { Completed on schedule. }\end{array}$ \\
\hline $\begin{array}{l}\mathrm{M}-34-04(\mathrm{~S} 01- \\
99-124)\end{array}$ & $\begin{array}{l}\text { "Submit Remedial Design Report/Remedial } \\
\text { Action Work Plan for the K Basins" }\end{array}$ & $\begin{array}{l}\text { Due } 3 / \mathbf{3 1 / 0 0} \text { completed } \\
\text { over one month carly } \\
\text { (February } 10,200() \text { ). }\end{array}$ \\
\hline$M-34-05(T 01)$ & $\begin{array}{l}\text { "Submit Report on Quantities, Character, } \\
\text { and Management of K Basins Debris" }\end{array}$ & $\begin{array}{l}\text { Due } 5 / 31 / 00 \text { - Completed } \\
\text { on schedule. }\end{array}$ \\
\hline
\end{tabular}

DNFSB Commitments

Nothing to report at this time.

\section{MILESTONE EXCEPTION REPORT}

$\begin{array}{lll}\text { Number/WBS Level Milestone Title } & \text { Baseline } & \begin{array}{l}\text { Forecast } \\ \text { Date }\end{array} \\ \text { Date }\end{array}$

\section{OVERDUe - 1}
S03-98-602
RL Contractor Operational Readiness Review
$09 /(07 /(0)$
111500

\subsection{1}

Cause: Inforesen delays in construction and testing brought on from technical issues within the fucilities.

Impact: None.

Corrective Action: Complete construction and testing to allow conducting the (ORR: 
FY 2001 Tri-Party Agreement / EA Milestones

\begin{tabular}{|c|c|c|}
\hline Number & Milestone Title & Status \\
\hline $\begin{array}{l}\mathrm{M}-34-16(\mathrm{~S} 00- \\
01-900)\end{array}$ & $\begin{array}{l}\text { "Initiate removal of } \mathrm{K} \text { West Basin Spent } \\
\text { Nuclear Fuel" }\end{array}$ & $\begin{array}{l}\text { Due } 11 / 30 / 00-0 \text { ) } \\
\text { schedule. }\end{array}$ \\
\hline M-34-06-T01 & $\begin{array}{l}\text { "Initiate } K \text { West Basin Spent Nuclear Fuel } \\
\text { Canister Cleaning Operations" TPA Change } \\
\text { request in preparation to extend due date. }\end{array}$ & $\begin{array}{l}\text { Due } 12 / 31 / 00-T P A \\
\text { Change request in } \\
\text { preparation to extend due } \\
\text { date. }\end{array}$ \\
\hline & DNFSB Commitments & \\
\hline & Nothing to roport at this time. & \\
\hline
\end{tabular}

\section{Performance Objectives}

Readiness for Fuel Movement (RC -1-1.a-I) -. Contractor completion of construction and operational testing, Management Self-Assessment (MSA).

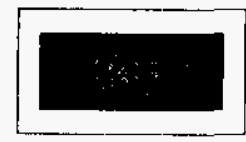
and Independent Operational Readiness Review (ORR) by September 14, 2000, to begin moving tuel hy November 30, 2000.

- Start of fuel movement is currently behind schedule to the November due date. The Contractor ORR started on September 28, 2000

Phased Startup Initiative (I'SI) (RC-1-1.a-II) - Complete PSI Phases 1 and 2 by April 15.2000. Includes successful Cold Testing of Integrated Water Treatment System (IWIS) \& Fuel Retrieval System (FRS).

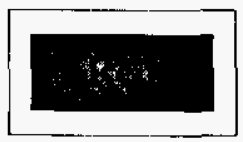

- This activity was completed late.

Accelerate Fuel Movement (R6-1SS-1) - Accelerate start of fuel movement.

- Pre-positioning of fuel processed in PSI Phase 111 will allow carly loading of Multi-Canister Overpacks (MCOS).

Yellow

Phased Startup Initiative (PSI) (RC-1SS-2) -... Complete Phases 3 and 4 by August 15, 2000. Includes completion of FRS/IWTS system testing using SNI (real fuel) and (ompletion of construction I)ocumentation Phase 2 (C'CD2).

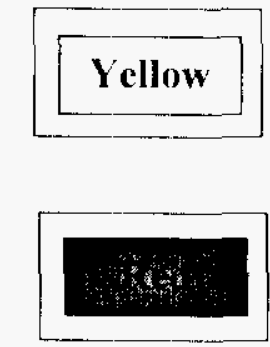

- Hot testing began October 18.2000. 


\section{KEY INTEGRATION ACTIVITIES}

- Spent Nuclear Fuel (SNF) final disposition interface activities, including (office of ("ivilian Radiation Waste Management (OCRWM) Quality Assurance (QA) Program implenentation. are ongoing with the National SNF Program. The SNF Project submitted eight ('orrective Action Closure packages to Rl. for National SNI: Program approval.

- The SNF Project and Waste Management Project continued preparations for K Basins" sludge removal and Shippingport (PA) Pressurized Water Reactor Core 2 SNI removal.

- The Programmatic Agreement between the River Corridor Project and the SNF Project for 324 Building (B Cell) SNF removal was approved.

- Neutron Radiography Facility Training Rescarch and lsotope Production (iencral Alomics (TRIGA) and Fast Flux Test Facility (FFTF) SNF relocation planning is ongoing with the FFTF Project.

- Bechtel Ianford. Inc. transmitted the transfer plan for SNF discovered during upcoming $105 \mathrm{~F}$ and $105 \mathrm{H}$ reactor basins deactivation for SNF Project review and approval. 


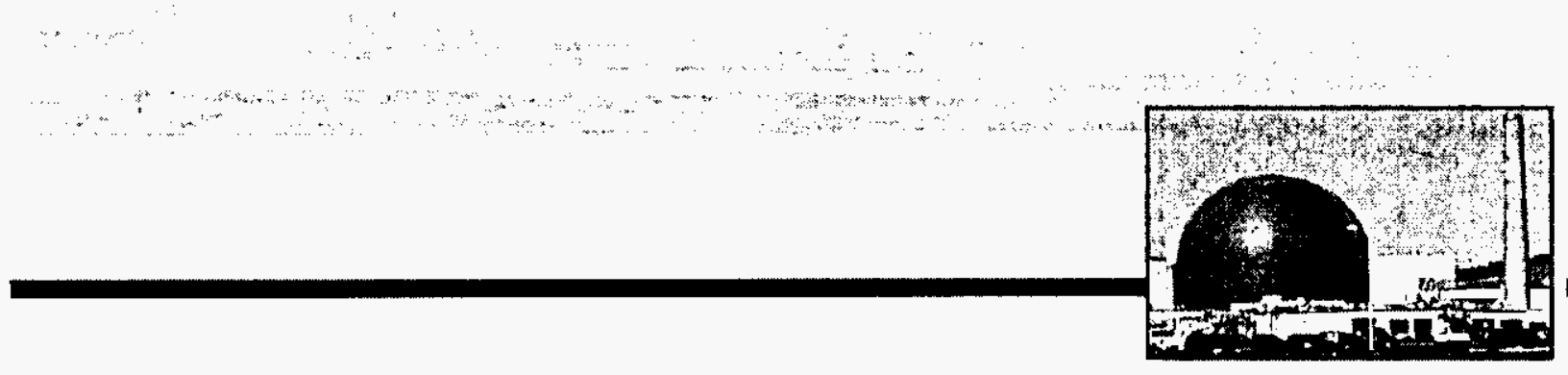

\section{Section E \\ Advanced Reactors Transition}

PROJECT MANAGERS

O.A. Farabee, RL

(509) 376-8089

D.B. Klos, FH (509) 373-3574 


\section{SUMMARY}

The Advanced Reactors Transition (ART) Program. WBS 1.12.1.1. PBS RI-TP11, consists of the 309 Building and the Nuclear Energy (NE) Legacies activities.

NOTE: All information is of September $30,2000$.

\section{Top 4 Accomplishments for FY 2000}

Residual sodium was reacted in three small tanks, using the water vapor-nitrogen process and the small cleaning station.

A decision to react the residual $\mathrm{NaK}$ in the Cooling I oop was made in January 2000, following the accident involving $\mathrm{NaK}$ at Oak Ridge. It involved reaction of about one pound of residual $\mathrm{NaK}$ from a cold trap cooling loop. This was the first use of the cleaning station to clean a piping system; all previous residue reaction work had been with residue remaining in tanks.

The 309 Bldg./Plutonium Recycle Test Reactor (PRTR) Tank Farm ion exchange column was stabilized, removed and shipped for burial along with associated above ground piping.

The 309 Bldg. $-32 \mathrm{ft}$ level of the containment building was cleaned up and stabilized.

Fiscal-year-to-date milestone performance (EA, DOI:-HQ, and RI) shows that there are no milestones due.

\section{Accomplishments this Reporting Period}

- For the month of September surveillance and maintenance activities continued on the $3(0)$ Building and NE legacies.

- Final rinsing and drying of the cold trap annulus side of the 33713 Cold Trap cooling system has been completed. The temporary connecting piping between the eleaning station and the system has been dismantled. The reaction process for all the residual NaK in the system is now complete. The cleaning station has been laid up for extended downtime. since all of the small alkali metal test systems have now been cleaned.

- Completed the 309 Building $-32 \mathrm{ft}$ level of the containn ent building clean up and stabilization.

- Work instructions have been prepared for stabilizing the Fuel Transfer Port in the 309 Building. 
- In preparation for transition of the 309 Building to the I:RC the - 32 fi level of the containment building was cleanted up. ('leanup consisted of removing steel l-beams, scallolding, materials and unatached equipment. In the process four $4 \times 4 \times 8$ it hoxes 500 cu.ft.) were filled. and removed to the containment main floor. Following material removal the thoors sumps and $8 \mathrm{ft}$. up the walls were wiped down and painted. In total about 9.000) sq.ft. Was wiped down and stabilized. The ('-Cell (with a floor area of 800 sy.ft) was down graded from a contamination area $(C A)$ to a fixed contamination area (F $(A)$.

\section{SAFETY}

Safety data for ART is included in a separate FFTF report.

\section{CONDUCT OF OPERATIONS / ISMS STATUS CONDUCT OF OPERATIONS}

Conduct of operations data for $A R T$ is included in a separate Fast Flux Test Facility (FF'TF) report.

\section{ISMS STATUS}

The [OOI: ISMS Phase 2 report, previously issued, was favorable.

\section{BREAKTHROUGHS / OPPORTUNITIES FOR IMPROVEMENT}

No breakthroughs or opportunities for improvement have been identified at this time.

\section{UPCOMING ACTIVITIES}

- Ship Thermal Transient Ioop cold trap oflsite

- Continue Fuel Transfer Pit cleanout in the 309 Building/PRTR facility. 
Cost Performance $(\$ M)$ :

\begin{tabular}{|l|c|c|c|}
\hline & BCWP & ACWP & VARIANCE \\
\hline Advanced Reactors Transition & $\$ 1.7$ & $\$ 2.2$ & $-\$ 0.5$ \\
\hline
\end{tabular}

The unfavorahle $\$ 0.5 \mathrm{M}(30$ percent) cost variance is not a true reflection of the ART performance for FY 2000. This is the result of the system not being able to split B\&R cost for EX-04-J1-02-0 between ART and FFTF. FFTF is partially supported by EX-04 funding which was utilized in September when $\$ 917 \mathrm{~K}$ of FFTF cost was booked. The true ART cost was $\$ 1.3 \mathrm{M}$ resulting in a $\$ 0.4 \mathrm{M}$ favorable variance.

\section{SChedule Performance ( $\$ M):$}

\begin{tabular}{|l|c|c|c|}
\hline & BCWP & BCWS & VARIANCE \\
\hline Advanced Reactors Transition & $\$ 1.7$ & $\$ 1.7$ & $\$ 0.0$ \\
\hline
\end{tabular}

The schedule variance is within acceptable thresholds.

\section{FY 2000 Cost/Schedule Performance - All Fund Types Cumulative to Date Status - (\$000)}

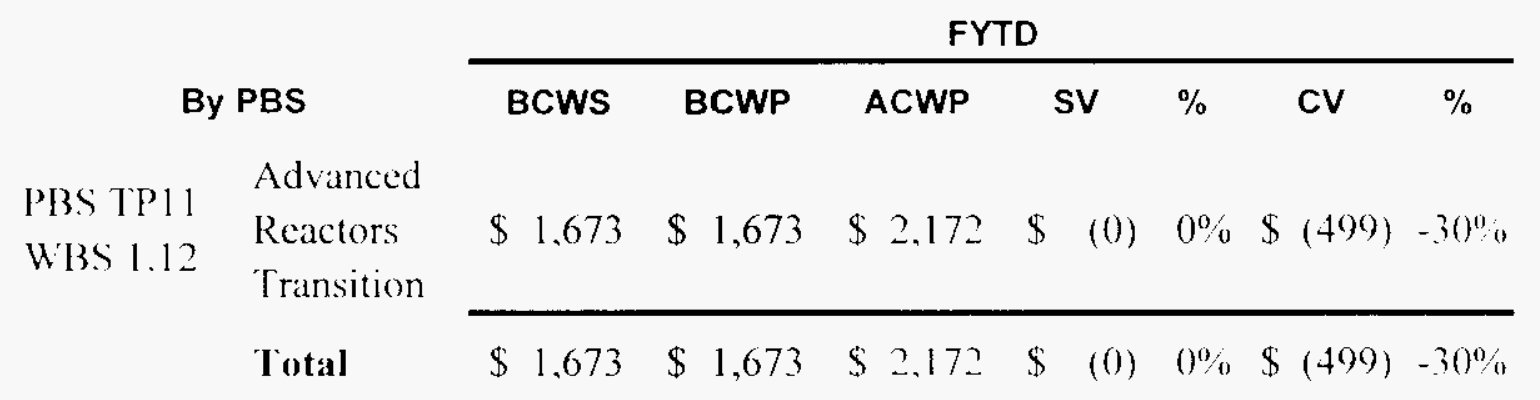




\section{Cost/Schedule Performance Indices (MONTHLY AND FYTD)}

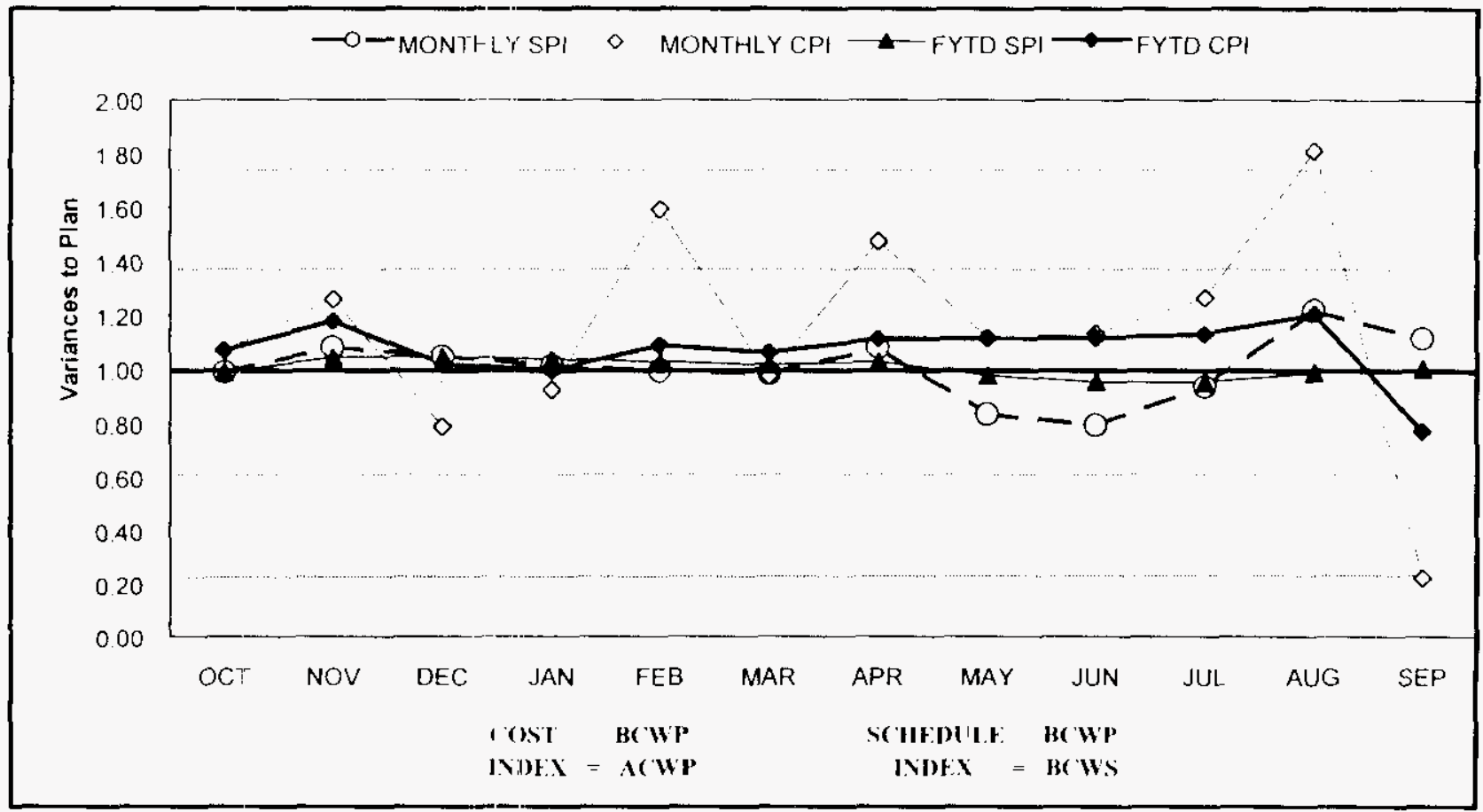

\begin{tabular}{|c|c|c|c|c|c|c|c|c|c|c|c|c|}
\hline $\mathrm{FI} 2000$ & OCI & NOY & $\mathrm{DEC}$ & $\mathrm{JAN}$ & $\mathrm{FEB}$ & $M M k$ & IVR & $\mathrm{Nu}$ & UN & . & (6) & SEl \\
\hline MONHLC Y SPL & 0.99 & 108 & 105 & 1.01 & 0.99 & 0.98 & 108 & 0.83 & 0.79 & 0.93 & 122 & 111 \\
\hline MUNHWL Y CE & 1.07 & 1.26 & 0.79 & 0.92 & 1.59 & 0.97 & 1.47 & 1.12 & 113 & 1.26 & 1.81 & 022 \\
\hline HYU SPL & 0.99 & 1.04 & (1) & 1.03 & 1.02 & 1.01 & 1.02 & 0.98 & 0.95 & 0.95 & 1199 & 100 \\
\hline 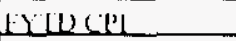 & 1.07 & 1.18 & 192 & 0.99 & 1.09 & 1.06 & 111 & $1.1]$ & 1.11 & $! 13$ & 1.20 & 0.77 \\
\hline MONLIIIY YBCWS & $\$ 79$ & $\$ 113$ & $\$ 88$ & $\$ 93$ & $\$ 116$ & $\$ 1.39$ & $\$ 116$ & $\$ 254$ & $\$ 146$ & $\$ 144$ & $\$ 196$ & $\$ 191$ \\
\hline MONIHLY BCWP & $\$ 78$ & $\$ 122$ & $\$ y ?$ & 894 & $\$ 115$ & $\$ 136$ & $\$ 125$ & $\$ 211$ & $\$ 115$ & $\$ 13.4$ & $\$ 234$ & $\$ 212$ \\
\hline MONTIIS $A C W D$ & $\$ 73$ & $\$ 97$ & $\$ 117$ & $\$ 102$ & $\$ 72$ & $\$ 140$ & $\$ 8.5$ & $\$ 189$ & $\$ 102$ & $\$ 106$ & $\$ 132$ & $\$ 957$ \\
\hline Fili) B ( Ws & $\$ 79$ & $\$ 192$ & $\$ 280$ & $\$ 373$ & $\$ 489$ & $\$ 627$ & $\$ 743$ & $\$ 997$ & $\$ 1,143$ & $\$ 1,286$ & $\$ 1.483$ & $\$ 1,6,73$ \\
\hline 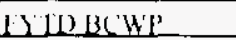 & $\$ 78$ & $\$ 200$ & $\$ 392$ & $\$ 386$ & $\$ 501$ & 56.37 & $\$ 761$ & $\$ 172$ & $\$ 1,088$ & $\$ 1.222$ & $\$ 1.401$ & $81,6,73$ \\
\hline WriL $\triangle W W$ & $\$ 73$ & $\$ 171$ & 5387 & $\$ 384$ & $3+61$ & $\$ f(x) 1$ & $\$ 8,86$ & $\$ 875$ & $\$ y>77$ & $\$ 1689$ & $\$ 1215$ & $\$ 2172$ \\
\hline
\end{tabular}

\section{COST VARIANCE ANALYSIS: $(-\$ 0.5 \mathrm{M})$}

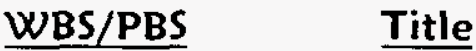

\section{$1.12 / T^{2} 11 \quad$ Advanced Reactors Transition}

Description and Cause: The unfavorable $\$(0.5 \mathrm{M}(30$ percent) cost variance is not a true reflection of the ART performance for FY 2000 . This is the result of the system not being able to split BKR cost for I:X-04-J1-02-0 between ART and FIYTF. FF"TF is partially supported by IXX(64 funding which was utilized in September when $\$ 917 \mathrm{~K}$ of fFTl cost was booked. The true ART cost was $\$ 1.3 \mathrm{M}$ resulting in a $\$ 0.4 \mathrm{M}$ favorable variance.

Impact: None.

Corrective Action: None. 
PHMC Environmental Management Performance Report - November 2000

Section E-Advanced Reactors Transition (ART)

\section{SCHEdUle VARIance ANALysis: (\$0.0M)}

$\underline{\text { WBS/PBS }}$

Title

$1.12 / \mathrm{TP} 11$

Advanced Reactors Transition

Description and Cause: None.

Impact: None.

Corrective Action: None.

\section{FUNDS MANAGEMENT \\ FUNDS VS SPENDING FORECAST ( $\$ 000)$ \\ FY TO DATE THROUGH SEPTEMBER 2000 \\ (FLUOR HANFORD, INC. ONLY)}

\begin{tabular}{|c|c|c|c|c|c|c|c|c|c|}
\hline & \multirow{2}{*}{\multicolumn{3}{|c|}{ Project cempletion:" }} & \multirow{2}{*}{\multicolumn{3}{|c|}{ Post 2006 }} & \multirow{2}{*}{\multicolumn{3}{|c|}{ Lineltems }} \\
\hline & & & & & & & & & \\
\hline & Funds & $\begin{array}{l}\text { Actual } \\
\text { Cost }\end{array}$ & Varlance & Funds & Actual Cost & Variance & Funds & $\begin{array}{c}\text { Actual } \\
\text { Cost }\end{array}$ & Variance \\
\hline \multicolumn{10}{|l|}{ The River } \\
\hline Total Advanced Reactors Operating & & & & \begin{tabular}{|ll}
5 & 4.19 \\
\end{tabular} & 52.073 & $\$ 2.126$ & & & \\
\hline Total Advanced Reactors Line Item & & & & & & & & & \\
\hline
\end{tabular}

- Control Point

\section{ISSUES}

There is nothing to report at this time.

\section{Baseline Change Requests Currently in Process}

\begin{tabular}{|c|c|c|c|c|c|c|c|c|}
\hline 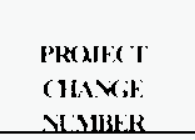 & $\begin{array}{l}\text { DAIE } \\
\text { ofalcill }\end{array}$ & BCR $U$ WLL & $\begin{array}{c}\text { Noocosis } \\
\text { IMPACT } \\
\text { S000 }\end{array}$ & $\begin{array}{lll}\mathrm{T} \\
\mathrm{S} & \mathrm{F} \\
\mathrm{C} & \mathrm{C} \\
\mathrm{H} & \mathrm{H} \\
\end{array}$ & $\begin{array}{c}\text { Bure } 10 \\
\mathrm{Cr}_{3}\end{array}$ & 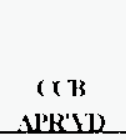 & 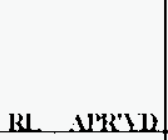 & $\begin{array}{l}\text { (1 BRFN) } \\
\text { slails }\end{array}$ \\
\hline ARI-2(x)(1)-1)(NH & $7 / 18 /(x)$ & $\begin{array}{l}\text { YY'(x) to'()] "Bridge } \\
\text { (harnge Requess" }\end{array}$ & 2,160 & $x|x|$ & $823(0)$ & 83100 & $922(x)$ & Aprorencel \\
\hline$A R T-2(x)(x-1)(x) 5$ & $9 / 21 /(n)$ & Rexrura Adj. & 0 & & $N / \Lambda$ & & & Approned \\
\hline $171-2(x) 1-(x) 2$ & $9 / 25 /(x)$ & $\begin{array}{l}\mid Y 2(x)\} \text { lix Reduction to } \\
(x) \%\end{array}$ & $-\$ 2$ & & & & & [ratt Phequared \\
\hline \multicolumn{9}{|c|}{ ADVANC WORК АITIOWIZTTIOM } \\
\hline & & $\begin{array}{l}\text { Vothing to report at this } \\
\text { time. }\end{array}$ & & & & & & \\
\hline
\end{tabular}


PHMC Environmental Management Performance Report - November 2000

Section E-Advanced Reactors Transition (ART)

\section{MILESTONE ACHIEVEMENT}

Fiscal-year-to-date milestone performance (I:A, I)( )E:-IIQ, and RL) shows that there are no milestones due.

Tri-Party Agreement/EA Milestones

Nothing to report at this time. DNFSB Commitments

Nothing to report at this time

\section{MILESTONE EXCEPTION REPORT}

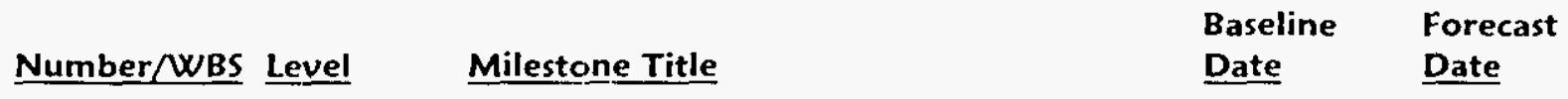

Overdue - 0

FORECAST LATE - 0

\section{Performance Objectives}

Nothing to report at this time.

\section{KEY INTEGRATION ACTIVITIES}

Nothing to report at this time. 


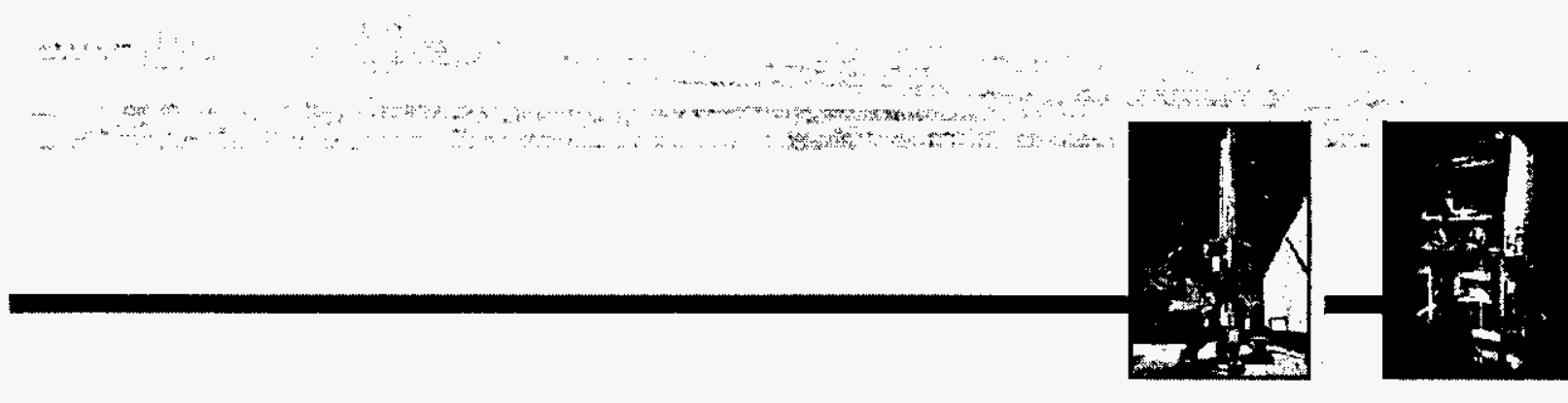

Section $\mathbf{F}$ EM-50

Science \& Technology Activities 


\section{Cost Performance $(\$ M):$}

\begin{tabular}{|c|c|c|c|}
\hline & BCWP & ACWP & VARIANCE \\
\hline Technology Development (EM-50) & $\$ 21.5$ & $\$ 20.0$ & $\$ 1.4^{*}$ \\
\hline
\end{tabular}

*Rounding

The unfavorable cost variance is within established thresholds.

\section{SChedule Performance ( $\$ M)$ :}

\begin{tabular}{|c|c|c|c|}
\hline & BCWP & BCWS & VARIANCF \\
\hline Technology Development (EM-50) & $\$ 21.5$ & $\$ 23.9$ & $-\$ 2.5 *$ \\
\hline
\end{tabular}

*Rounding

The $\$ 2.5$ million ( 10 percent) unfavorable schedule variance is primarily the result of PNNI. EM-50 projects work scope deferred to FY 2001 and FY 2002 for better utilization of funding allocations. Funding for PNNL three-year project allows for work scope adjustments without issue. FH's portion of TI) $(\$ 1.0 \mathrm{M})$ is within thresholds.

\section{Milestone ACHIEVEMENT}

\begin{tabular}{|c|c|c|c|c|c|c|c|c|}
\hline \multirow[b]{2}{*}{ MILESTONE TYPE } & \multicolumn{4}{|c|}{ FISCAL YEAR-TO-DATE } & \multicolumn{3}{|c|}{ REMAINING SCHEDULED } & \multirow[b]{2}{*}{$\begin{array}{l}\text { TOTAL } \\
\text { FY } 2000\end{array}$} \\
\hline & Completed Early & $\begin{array}{c}\text { Completed On } \\
\text { Schedule }\end{array}$ & $\begin{array}{l}\text { Completed } \\
\text { Late }\end{array}$ & Overdue & $\begin{array}{c}\text { Forecast } \\
\text { Early }\end{array}$ & $\begin{array}{l}\text { Forecast } \\
\text { On } \\
\text { Schedule }\end{array}$ & $\begin{array}{c}\text { Forecast } \\
\text { Late }\end{array}$ & \\
\hline Enforceable Agreement & 0 & 0 & 0 & 0 & 0 & 0 & 0 & \\
\hline DOE-HQ & 0 & 0 & 0 & 0 & 0 & 0 & 0 & 0 \\
\hline $\mathrm{RL}$ & 0 & 0 & 1 & 0 & 0 & 0 & 0 & \\
\hline Total Project & 0 & 0 & 1 & 0 & 0 & 0 & 0 & 1 \\
\hline
\end{tabular}

\section{MILESTONE EXCEPTION REPORT}

$\begin{array}{lll}\text { Number/WBS Level } & \text { Milestone Title } & \begin{array}{l}\text { Baseline } \\ \text { Date }\end{array}\end{array}$




\section{TECHNOLOGY DEPLOYMENTS}

The following table is a listing of EM funded Technology Deployments for FY 2000 . These deployments are discussed in the applicable Project Sections.

\section{FY 2000 TECHNOLOGY DEPLOYMENTS}

\begin{tabular}{|c|c|c|}
\hline Technology Name & $\begin{array}{c}\text { Actual } \\
\text { Date }\end{array}$ & Project \\
\hline Small Diameter (ieophysical logging System & $01-\wedge p r-00$ & ERC \\
\hline Overview Video System & $01-А р г-(0)$ & IRC \\
\hline L.iquid-I evel Detection Technology (Ultrasonies) & $01-A \mathrm{pr}-00$ & IRC \\
\hline Passive Soil Vapor Ixtraction (Barometric Pumping) & $01-\Lambda p^{\prime}-00$ & $\mathrm{ERC}$ \\
\hline Stabilizing Low-I.evel Category 3 Waste Using Special Concrete & $01-A p r-00$ & WM \\
\hline Advanced Characterization System & $3(0-\operatorname{Jun}-(0)$ & I:RC \\
\hline Wireline Cone Penetrometer System for Multiple Tool Usage & $31-J u l-00$ & $\mathrm{IRC}$ \\
\hline Supervisory Control and Data Acquisilion (SCADA) & $31-\mathrm{Jul}-00$ & I.I. \\
\hline Drain Line Characterization Robot & $31-A u g-00$ & IRC: \\
\hline Mini-Robet for Removal of Dispersbles in B-Cell & $31-A u g-(00$ & \% \\
\hline HANSF: Allalysis Tool & $31-A u g-00$ & $\mathrm{SNF}$ \\
\hline Cold Vacuum I)rving & $31-\Lambda u g-00$ & $\mathrm{SNl}$ \\
\hline In Situ Object Counting System & $30-\$<p-00$ & l:RC \\
\hline Remote concrete Coring System & $3(0-S \mathrm{Sep}-00)$ & $\operatorname{lkC}$ \\
\hline Packaying (bigkess transfer) Process & $36-$ Sep-(1)0 & NMS \\
\hline Pipe-N-cio Repackaging Technique: & $30-S \mathrm{Sep}-00$ & NMS \\
\hline Magnesium Hadroxide Precipitation & $30-\operatorname{Sep}-00$ & N.MS \\
\hline
\end{tabular}




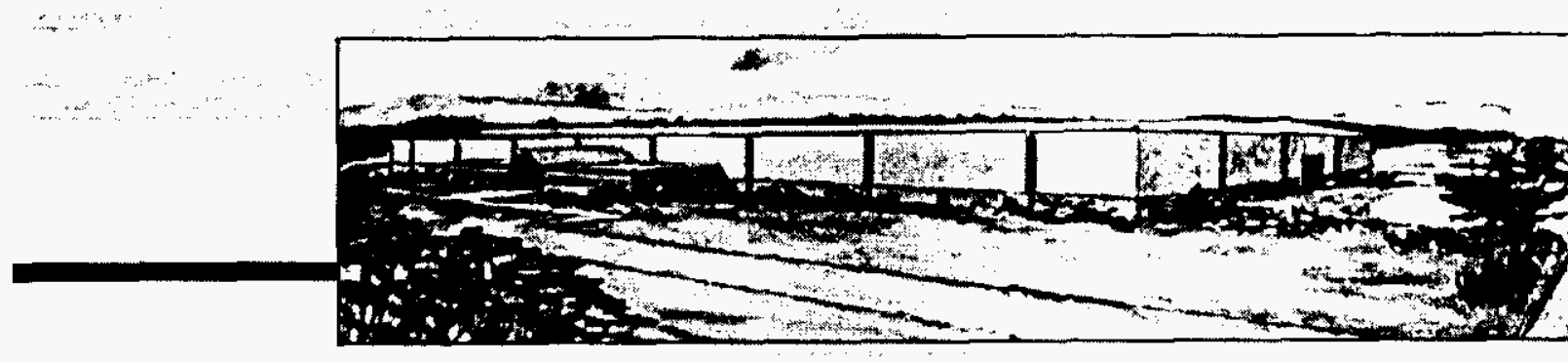

\section{The Future}

Hanford cleanup activities develop assets - people, experience, land, buildings, research and training facilities - that can have a positive affect on our future. They can help solve national and global problems in food

production, global warming, pollution and nuclear non-proliferation.

The prime contractors and subcontractors at Hanford are implementing economic development initiatives aimed at weaning the Tri-Cities from

dependence on federal cleanup dollars. These initiatives are being supported with grants and by freeing up valuable site resources for use by the private sector. Examples of these initiatives are a new industrial building to attract new businesses to the area, job-creation efforts, and providing technical assistance to entrepreneurs. The Volpentest HAMMER Training and Education Center is included in this outcome. HAMMER provides training for the Hanford Site cleanup mission and the DOE complex. The Center also augments economic diversification by creating a state-of-the-art regional training industry for students from across the nation and around the world. 

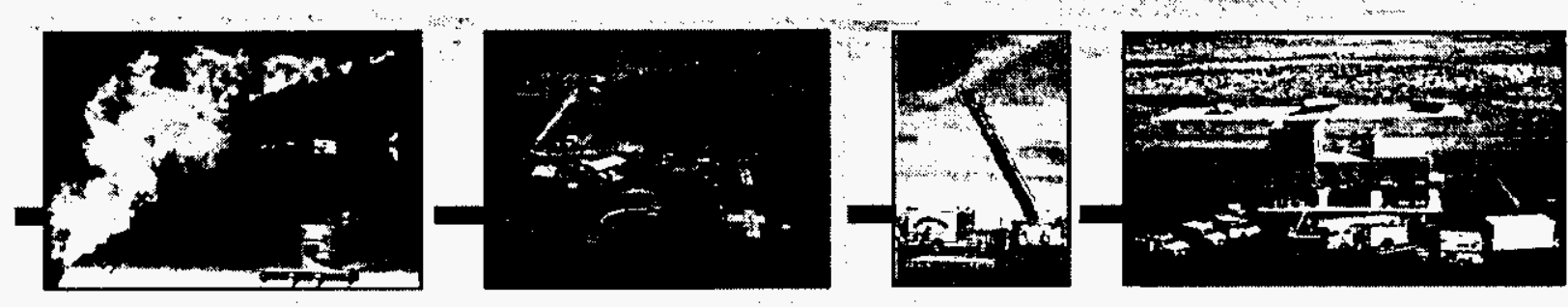

\section{Section G HAMMER}




\section{SUMMARY}

The Hazardous Materials Management and Emergency Response (HAMMER) mission arcil consists of the HAMMER project. WBS 1.9.1.1. Project Baseline Summary (PBSS) HAMO1.

NoTH: I Inless otherwise noted, the Safety, Conduct of Operations. Milestone Achievement. and Cost/Schedule data contained herein is as of the end of Septemher 2000 . All other information is as of October $21,2000$.

The FY 2000 Volpentest HAMMER overall performance was excellent. The project remained clearly focused on achieving the FY 2000 objective - "operate the Volpentest HAMMER Training and Education Center (HAMMER) in a safe and effective manner". The Center's continued commitment to operational and training safety resulted in an excellent safety record with no lost workday cases. In fact, there have been no lost workday cases since opening the new facility in September 1997.

\section{Top 5 Accomplishments for FY 2000}

Volpentest HAMMLR's first priority is to deliver hands-on training to the Hanford workforce. One thousand eight hundred twenty classes were conducted at the Volpentest HAMMER facility, for a total of 28.077 Hanford site student days (milestone \#HMR-(00-002). This represents a 14 percent increase over the FY 1999 actual student day total of 24.569 and exceeds the FY 200010 pereent target. Highest attended health and safety classes included Hazardous Waste Operations. Respiratory Protection, Radiation Worker II Requalification. Basic Medic First Aid training. and Basic Crane and Rigging. Fffectiveness was evidenced by high student satisfaction ratings. The ratings remained high throughout FY 2000 due to a strong customer service commitment by stafl members (Progress).

Milestone \#HMR-00-004 was successfully completed and exceeded expectations for increasing the HAMMLR facility utilization. The goal for FY 2000 was 32.137 student days including Hanford and non-Hanford students, which is a 10 percent increase over 29.215 actual student days in FY 1999. The FY 2000 actual student days total was 33.054 , which is a 13 percent increase over FY 1999. Additionally, a second deliverable of this milestone was to increase prop usage by 10 pereent over FY 1999. The goal for FY 2000 was 21.7 pereent. which is a 10 perent increase over the 19.8 percent actual usage in $\mathrm{FY} 1999$. The actual $\mathrm{FY} 2000$ prop usige was 23.2 percent, which is an exceptional 17 percent increase over FY 1999. and is proof that more classes are using hands-on learning (Progress).

('onstruction was completed on HAMMER's new $60^{\circ} \times 60^{\circ}$ Training Support Building (TSB) Anmex Building in January 2000 providing much-needed adi. onal classroom space and a practical area for Respiratory training (Progress). 


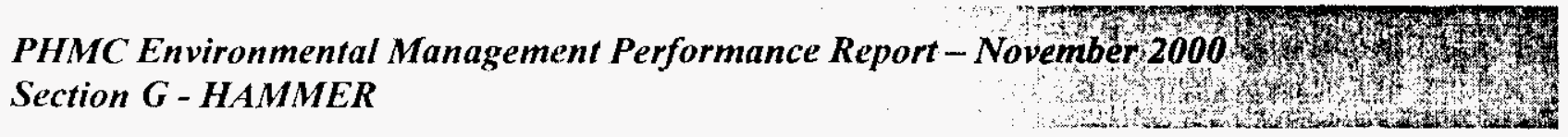

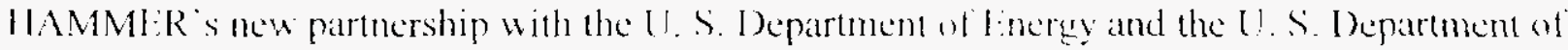
labor, (OSHA was formally reconnized in March 2000. The new alliance brings rigorous, highquality, performance-based courses (formerly offered only in Des Plaines, Illinois) to HAMML:R and Hanford Site workers (Progress).

Milestone $\#$ HMR-00-003 was sucessfully completed and exceeded expectations for increasing the number of return user facility customers. The goal for $\mathrm{FY} 2000$ was 17 return user facility customers, which is a 10 percent increase over 15 return user facility customers in IY 1999. HAMMER achieved 30 return user facility customers, which is an outstanding 100 percent increase over FY 1999. In association with this, HAMMLR successfully completed milestone \#HMR-(0)-005 for increasing reimbursable Work For Others (WFO) and cost offset. The goal for FY 2000 was $\$ 416,000$, which is a 25 percent increase over $\$ 332,400$ in FY 1999. The actual FY 2000 reimbursable WFO and cost offset total is $\$ 485.900$, which is a 46 percent increase over FY 1999 (Progress).

\section{Additional FY 2000 Accomplishments}

\section{Progress}

Completed milestone \#HMR-00-001 - to establish a methodology for measuring employer satisfaction. A methodology was developed for internal customers to establish a baseline of statistical data and comments. Non-Hanford customers are currently surveyed via the existing customer satisfaction system, which was developed in FY 1999. DOE-RI indicated that they wanted additional customer feedback from non-Hanford customers, so an additional methodology was formulated to address this request.

A total of 52 Hanford Site Lmergency Preparedness (LP) Initial training courses were presented during FY 00 for a total of 656 students. In addition, this year 445 students were able to receive Refresher training via the Web. Courses included Building Warden Initial and Refresher, Building Emergency Director Initial and Refresher, Hanford Incident Command System Initial and Refresher, and EP Drill Coordinator Initial.

Construction was completed on HAMMER's new TSB Computer-Based Training Room in January 2000 providing much-needed space for RadWorker training.

HAMMER's new partnership with the U. S. Department of Energy, Northwest Public Power Association (NWPPA) and the Eastern Washington Electric Utility (iroup became official in June 2000 . The new alliance will bring a 40 -acre "electrical city" to the facility for NWPPA personnel. Hanford Site High Risk Electrical Workers, and others.

September accomplishments include: initiated preparations for the construction of a laser containment facility in the TSB at HAMMLR. Bechtel-Nevada, I.ANI and the Hanford Site have jointly developed the laser, as a much faster and cleaner method of eutting up unwanted material. The laser is expected to arrive in January 2001. with a DOE complex wide demonstration to be presented in March 2001. Additionally. the quarterly Eastern Washington State Agencies Trainer Round Table meeting was held. Representatives from I abor and 
Industries. ('orrections. I icensing. Department of Transportation. I)epartment of tadety and Health Services. I epartment of Personnel and Employment Security ()fice attended this meeting. HAMMER`s teleconferencing center was demonstrated and several of the meeting attendees toured HIAMMER facility to view and discuss possible use of HAMMER in their areas of responsibility. In addition, the Northwest Regional Administrator of the Federal Rail Administration, Region VIII, visited the HAMMER facility. Discussions on partnership opportunities were conducted and future meetings are planned to discuss the potential for HAMMI:R to become this region`s training facility.

Fiscal-year-to-date milestone performance (EA, DOE-HQ and RI.) shows that four of five milestones ( 80 percent) were completed ahead of schedule, and one milestone (20 percent) was completed late. The Milestone A, ievement details, found following the Bascline (hange Request status, provide further information on all milestone types.

\section{ACCOMPLISHMENTS}

- Initiated preparations for the construction of a laser containment facility in the ISB.

- Conducted the quarterly Eastern Washington State Agencies trainer Round Table meeting.

- Conducted the Northwest Regional Administrator of the lederal Rail Administration. Region VIII meeting to discuss partnership opportunities and future training opportunities.

HAMMER currently has no status to report in the areas of ISMS Status, Breakthroughs and Opportunities for Improvement.

\section{UPCOMING ACTIVITIES}

- An Archeologica! Resources Protection Act Incident Investigation class has been scheduled for October 2000 .

- WSL $i$ will present a Certified HAZMAT Manager National Test Preparation (lass in ()etober 2000 .

- Washington State Department of Ecology will present an interagency Spill Workshop in october 2000 .

- IHAMMFR will hold the first Firefighter Physical Ability test in ()ctober 2000).

- WSI will present an emergency Preparedness for Terrorism class in 1 )ecember $200(0$. 


\section{Cost Performance ( $\$ M)$ :}

\begin{tabular}{|l|c|c|c|}
\hline \multirow{2}{*}{ HAMMER } & BCWP & ACWP & VARIANCE \\
\hline
\end{tabular}

The favorable cost variance of $\$ 0.4 \mathrm{M}(8$ percent $)$ is within established thresholds.

\section{Schedule Performance ( $\$ M)$ :}

\begin{tabular}{|l|c|c|c|}
\hline & BCWP & BCWS & VARIANCE \\
\hline HAMMER & $\$ 5.8$ & $\$ 5.9$ & $-\$ 0.1$ \\
\hline
\end{tabular}

The unfavorable schedule variance of $\$ 0.1 \mathrm{M}(2$ percent $)$ is within established thresholds.

FY 2000 Cost/Schedule Performance - All Fund Types Cumulative to Date Status - $(\$ 000)$

$$
\text { FYTD }
$$

\section{Green}

By PBS

\begin{tabular}{lllllll}
\hline BCWS & BCWP & ACWP & SV & $\%$ & CV & $\%$
\end{tabular}

PBS IIMO1

W'BS 1.9.1 Hammer

$\$ 5,936 \quad \$ 5,813 \quad \$ 5.371 \quad \$(123) \quad-2 \% \quad \$ 442 \quad 8 \%$

Total

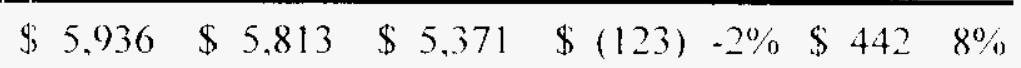




\section{Cost/Schedule Performance Indices (MONTHLY 2000 AND FYTD)}

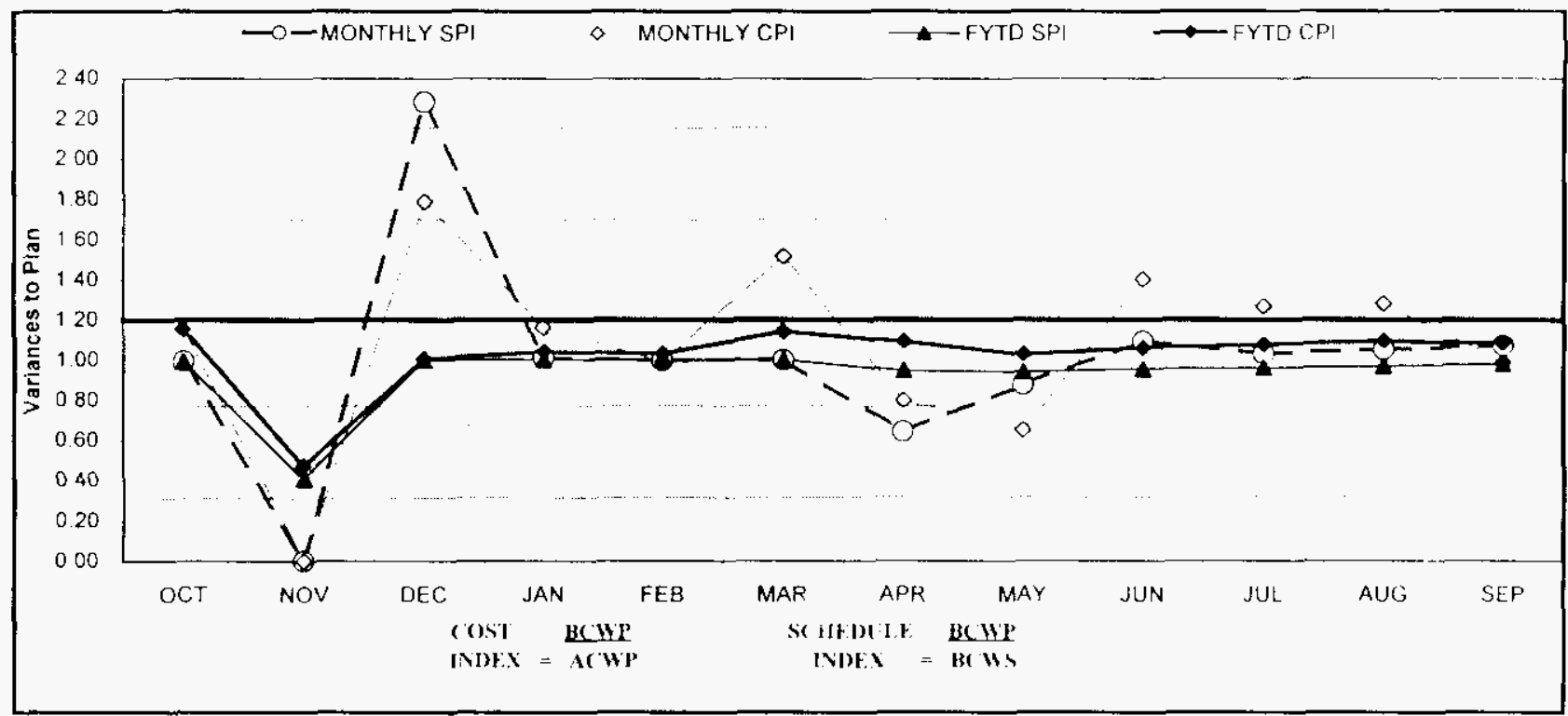

\begin{tabular}{|c|c|c|c|c|c|c|c|c|c|c|c|c|c|c|c|c|c|c|c|c|c|c|c|c|}
\hline FV 2600 & \multicolumn{2}{|c|}{ C) I } & \multicolumn{2}{|c|}{$x(1)$} & \multicolumn{2}{|c|}{ DEC } & \multicolumn{2}{|r|}{ Jis } & \multicolumn{2}{|r|}{ FEB } & \multicolumn{2}{|c|}{ MAR } & \multicolumn{2}{|r|}{ APK } & \multicolumn{2}{|c|}{ MII } & \multicolumn{2}{|c|}{112} & \multicolumn{2}{|r|}{.11} & \multicolumn{2}{|c|}{$\Delta 1 \%$} & \multicolumn{2}{|c|}{ SFY } \\
\hline MONTIILY SP! & & 099 & & $0(0)$ & & $\therefore 28$ & & 1.01 & & 100 & & 1.00 & & 004 & & $08 \mathrm{x}$ & & 101, & & 103 & & ] द厶 & & $11^{\circ}$ \\
\hline MOINIEIIYY 'Pl & & 116 & & (i) (ii) & & 770 & & 1.16 & & 099 & & 151 & & 0.80 & & 065 & & $1+10$ & & 1.27 & & $1 \therefore x$ & & $(3+2)$ \\
\hline FYID SP! & & 040 & & if.+1 & & $1.0(0)$ & & 1.00 & & 1.00 & & 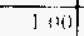 & & 0.95 & & (1) 4.4 & & 4195 & & (1) +2, & & $(v)^{-1}$ & & $1+1)$ \\
\hline FYII) (P) & & 1.16 & & 0.47 & & (i) & & 104 & & 1.03 & & 1.1 .1 & & T.tu & & 103 & & 100, & & 10 & & $f(110$ & & 1,18 \\
\hline MUNTIHY BEWS & $\$$ & 351 & 5 & 507 & $\$$ & $3 \% 0$ & $\$$ & 418 & 5 & 440 & $\$$ & 914 & 3 & 4.11 & $\$$ & 793 & $\$$ & 425 & 5 & 425 & 8 & $5 i 1$ & $s$ & $5, ?$ \\
\hline MONTHIY BCWP & 5 & 350 & 8 & - & $s$ & 504 & $s$ & $4 ? 2$ & $\$$ & 438 & 5 & 913 & $\$$ & 8.7 & 8 & 3.19 & 8 & $41 \cdots$ & 8 & $4:$ & $s$ & 587 & 5 & in: \\
\hline MONIHI.YACWP & $s$ & 303 & s & 430 & 8 & 50 & 5 & 363 & $\$$ & 443 & $\$$ & 60.3 & $\$$ & $4: 5$ & $\$$ & 5.1 & $\$$ & $3: 1$ & 5 & 3.45 & $\$$ & $.45 x$ & 3 & $6 l^{\circ}$ \\
\hline $\mathrm{FYTIOBCWS}$ & 8 & 342 & $\$$ & 859 & $\$$ & 1.255 & $b$ & $1,6.73$ & $\$$ & 2,113 & $\$$ & 3,027 & $s$ & 3.568 & $\$$ & $\overline{3.96 .1}$ & $s$ & 1. $3 x+1$ & 5 & 4.810 & $\$$ & $f(3,1)$ & 5 & i.1) it. \\
\hline (Y) $A\left({ }^{\prime}\right)^{\prime}$ & 5 & 3113 & $\$$ & 7.11 & 5 & 1.2 .47 & 5 & 1.610 & 5 & 2053 & 5 & 2656 & $\$$ & $3(10)$ & 8 & 7.6.?? & 8 & $35 ;$ & $\$$ & 4.248 & 5 & 4.790 & 8 & \\
\hline
\end{tabular}

\section{COST VARIANCE ANALYsIS: (\$0.4)}

\section{WBS/PBS TITLE}

\subsubsection{1/HMO1 HAMMER}

Description and Cause: The variance is within thresholds.

Impact: None.

Corrective Action: None.

\section{SCHEDULE VARIANCE ANALYSIS: (-\$0.1)}

\section{$\underline{\text { WBS }}$ TITLE}

\subsubsection{1/HMO1 HAMMER}

Description and Cause: The variance is within thresholds.

Impact: None.

Corrective Action: None. 


\section{FUNDS MANAGEMENT \\ FUNDS VS SPENDING FORECAST ( $\$ 000)$ FY tO DATE THROUGH SEPTEMBER 2000 \\ (FLUOR HANFORD, INC. ONLY)}

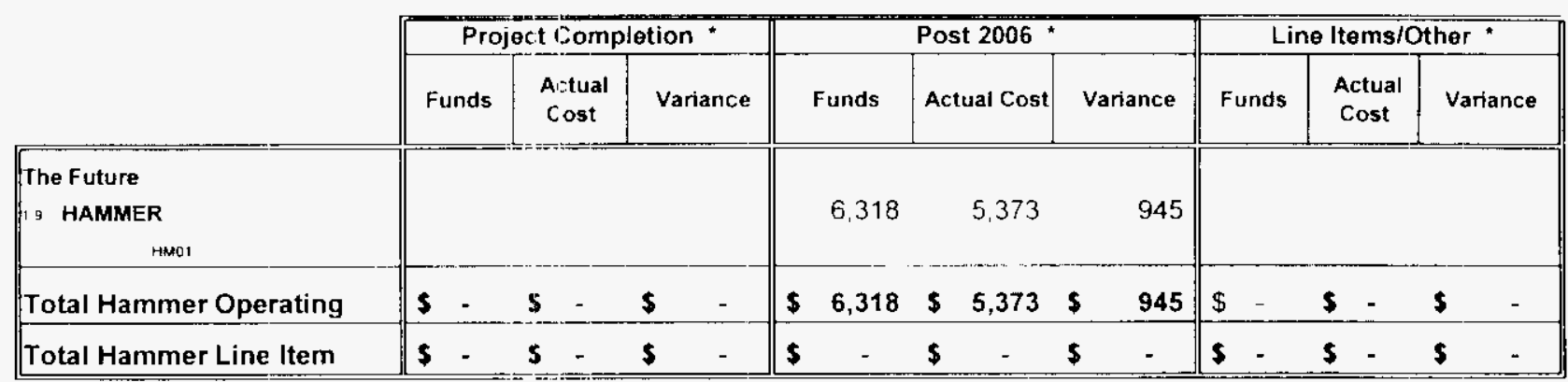

* Control Point

\section{ISSUES}

Nothing to report at this time.

\section{Baseline Change Requests Currently in Process}

(\$000)

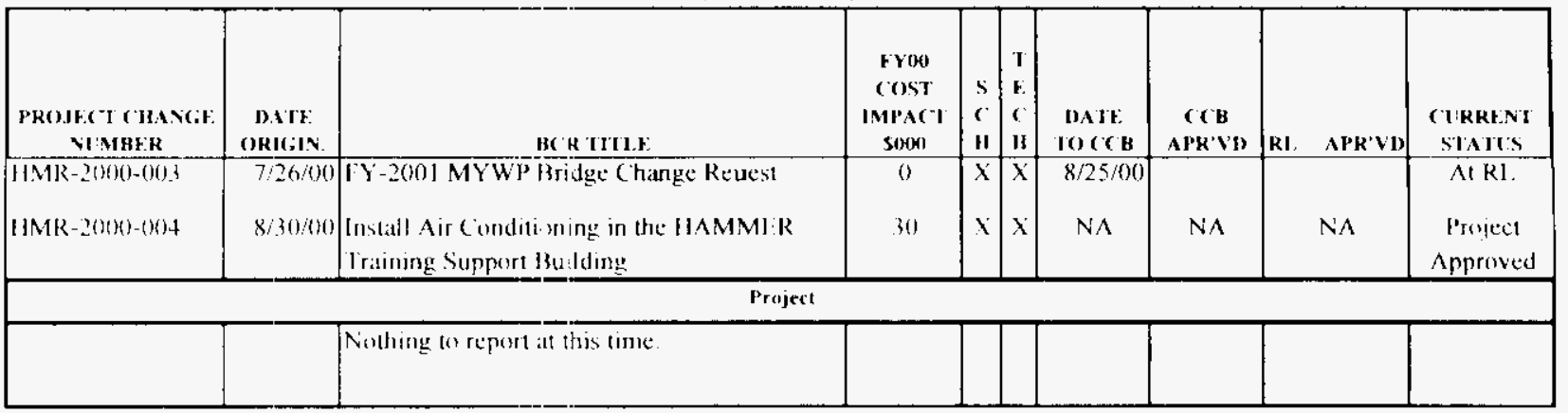


PHMC Environmental Management Performance Report - November 2000 Section G - HAMMER

\section{MiLESTONE ACHIEVEMENT}

\begin{tabular}{|c|c|c|c|c|c|c|c|c|}
\hline \multirow[b]{2}{*}{ MLES TONE TYPE } & \multicolumn{4}{|c|}{ FISCAL YEAR-TO-DATE } & \multicolumn{3}{|c|}{ REMAINING SCHEDULED } & \multirow[b]{2}{*}{$\begin{array}{l}\text { TOTAL } \\
\text { FY } 2000\end{array}$} \\
\hline & $\begin{array}{c}\text { Completed } \\
\text { Early }\end{array}$ & $\begin{array}{l}\text { Completed } \\
\text { On Schedule }\end{array}$ & $\begin{array}{c}\text { Completed } \\
\text { Late }\end{array}$ & Overdue & $\begin{array}{c}\text { Forecast } \\
\text { Early }\end{array}$ & $\begin{array}{l}\text { Forecast On } \\
\text { Schedule }\end{array}$ & $\begin{array}{l}\text { Forecast } \\
\text { Late }\end{array}$ & \\
\hline Enforceable Agreement & 0 & - 0 & 0 & 0 & c & 0 & & \\
\hline DOE-HQ & 0 & 0 & 0 & 0 & $\tau$ & 0 & & \\
\hline $\mathrm{RL}$ & 4 & 0 & 1 & 0 & c & 0 & & \\
\hline Total Project & 4 & 0 & 1 & 0 & c & 0 & & \\
\hline
\end{tabular}

\section{Green}

\section{Tri-Party Agreement / EA Milestones}

Nothing to report at this time.

\section{DNFSB Commitments}

Nothing to report at this time.

\section{MILESTONE EXCEPTION REPORT}

Number/WBS Level Milestone Title

Baseline Forecast

OVERdue - 0

Date Date

Forecast LATE - 0 


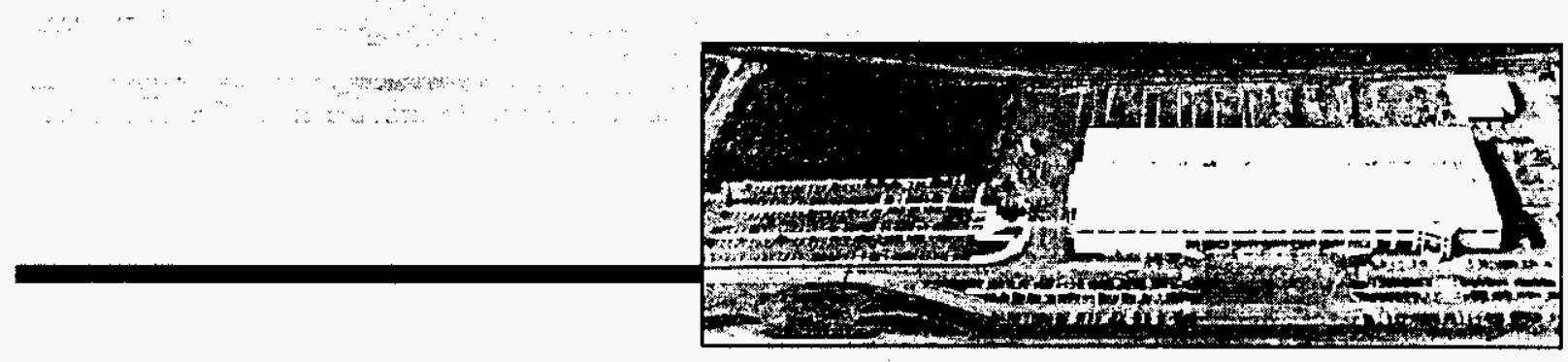

\section{Multiple Outcomes}

Projects that bridge more than one outcome are included here. These projects include Landlord, Support, and National Programs. Further descriptions are included in each section. 

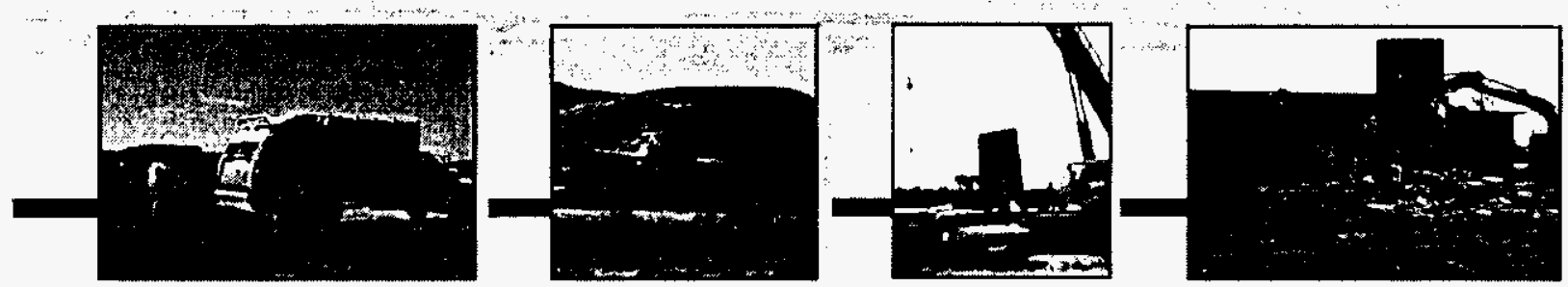

\section{Section H Landlord}

PROJECT MANAGERS S.H. Wisness, RL (509) 373-9337

D.S. Kelly, FH (509) 376-7334 


\section{SUMMARY}

The Landlord mission area consists of the I andlord Project. WBS 1.5.1. Project Bascline Summary (PBS) RI -TP13.

NOTF: Unless otherwise noted, the Safety, Conduct of Operations. Milestone Achievement, and Cost Schedule data contained herein is as of September 30,2000 . All other information is as of October 19, 2000.

The Landlord Project FY 2000 overall performance exceeded expectations. The project's focus on meeting the Multi-Year Work Plan commitments remained a high priority and as a result, 10() percent of the planned milestones were successfully completed ahead of schedule. Outlined below are the most significant FY 2000 accomplishments.

\section{Top 5 Accomplishments for FY 2000}

Legacy rail cars destined for burial as low-level waste were successfully diverted by decontaminating and excessing for sale or re-use. A contaminated 100-ton well car was prepared for offsite transport, loaded on a truck at the 212R Rail Siding on July 12 and shipped to a vender in Tennessee for the DOE Shield Block Program. The well car disposition was completed in August when the wheels were buried onsite in the low-level burial grounds (RL Milestone I.I.P00-450). One flat car was transferred from DOE-RL, ownership to the Tri-City Asset Reuse Corporation (TARC) and two more were prepared for transfer (Completion and Removal).

Capital equipment upgrade costs were avoided by free releasing and selling four regulated and two non-regulated cranes at auction generating over $\$ 700 \mathrm{~K}$ in total revenue. The money was used to purchase a new 70-ton hydraulic mobile crane for use in the Tank Farms (Momentum)

The Landlord Master Plan was developed, which will integrate mission requirements with physical infrastructure capabilities and develop tactical planning aligned with the desired end state. The plan establishes detailed plans for nine functional areas within the l andlord Project. consistent with the Site`s Strategic Objectives. Opportunities exist to shore-up the Iandlord Project's Lifecycle Baseline, in concert within the projects identified in the Master Plan. The plan also applies a commercial municipal approach to site planning and management. This process will be renewed annually (Progress).

The demolition phase of Project L-270, "Emergency Services Renovation, 200 Area." was completed on February 24, 2000. This demolition removed the $609 \mathrm{C}$ wing of the 200 Areal lire Station, which was required to make way for the construction of the new living quarters/administration addition (approximately 11.000 square fect) (Momentum).

RI. Milestone I.I.P-00-435, "Project L-312, 2101M, MO-235, and Associated Buildings Storm Drainage Resolution" construction was completed one wech ahead of the scheduled completion date of August 4, 2000. This milestone helps resolve storm drainage problems around facilities in 200 East and West Areas. The water accumulation from the storm water runoff ereated unsafe walking conditions for pedestrians and unsafe driving conditions for vehicles (Progress). 


\section{Additional FY 2000 Accomplishments}

\section{Momentum}

RI. Milestone 1.1.P-00-425, "( omplete Definitive Design for Project I-310. Replace Distribution Water line to 200 West" was completed two days ahead of the scheduled due date of May 26 , 2000. C'onstruction for this project is scheduled in FY 2001 and it replaces the existing 24-inch Export Water I.ine (f:WL.) between the $2901 \mathrm{Y}$ Valve House and the $200 \mathrm{~W}$ Water Reservoir (approximately 2.5 miles longl. The existing line is over 50 years old, has experienced several leaks in the past tive years, and is the sole E.Wl. to the 200 Area Water Treatment Plant.

RI. Milestone LLP-(00-440, "Project L-298. FY 2000 Road Refurbishments," was completed eight days ahead of the scheduled completion date of September 29. The FY 2000 roadwork included: widening and overlay of the Rattlesnake Barricade Access Road (to make permanent safety improvements to this Site acess road).

RL. Milestone LLP-00-415, "Preject L-309, Replace Section of Main Water I ines (200) East)," was completed ahead of schedule on September 28,2000 . 'This project replaced approximately 1.200 feet of undersized, temporary two-inch sanitary water line in 200 East $A$ rea near the $272 \mathrm{AW}$ Building with a new six-inch line.

\section{Progress}

Additional lighting in the south parking lot for 2750 r : Building was required to resolve employee concerns associated with inadequate lighting levels. This project was added to the I andlord Project baseline in January 20(10) by BCR L.PM-2000-001 to resolve the employee concern on an accelerated basis. Overall construction was completed on $A$ pril 4 , approximately two months ahead of schedule and under budget.

RI. Milestone L.L.P-()()-405, "Bunker Tank Removal Preparation" was completed fourteen wecks ahead of the scheduled due date of September 29,2000. This milestone completed activities to prepare the 384 Powerhouse Bunker Tanks for removal in FY 2001. This included removal of the 366-A Building. relocation of a fire hydrant, cleaning out a french drain, and taking other preliminary steps to prepare fo- tank removal and management of fuel contaminated soil.

RI. Milestone II,P-()(1-400, "Surveillance/Maintenance, Shutdown, \& Isolation ()f Vacant Facilities," was completed eight days ahead of schedule on September 21, 20000. This activity provided Surveillance and Maintenance (S\&M) of vacant facilities, shutdown of 20 facilities, and deactivation (utilities isolated) of 25 vacant facilities.

R1. Milestone L.P.P-(0)-401. "Complete Bridge Baseline (hange Request in Support of MYWP Ipdate by August 25, 2000" was completed three weeks ahead of schedule. This year the MYWP was divided into two phases. Phase I was intended to baseline FY 2001 and incorporated a funding constraint of $\$ 19 \mathrm{M}$ which deferred $\$ 11 \mathrm{M}$ of work scope to the outer years. Phase I also addressed additional requirements for the aging infrastructure in FY 2002 per the Infrastructure Restoration l'an. Phase II of the MYWP is in process and includes indirect-lo- 
direct conversion and the Preferred Schedule Options Study for a lifecycte biseline

A new lilectrical I tilities Supervisory Control and I)ata Acquisition (S( ADA) system was deployed that is a P' (-based computer control system that provides remote control. data acquisition and event reporting over the major substations of the Hanford High Voltage Iflectrical Power Distribution System. The telemetered data is stored for historical and trending purposes and is available to engineering and maintenance personnel for post-mortem analysis. system performance studies and validation of metered energy consumption data. The system is current state of the art software/hardware and can easily evolve as necessary. (other benefits include effective control of electrical power substations, risk reduction of system lailures, and a reduced life cycle maintenance cost of $\$ 1.7 \mathrm{M}$.

\section{Completion and Removal}

There are several areas on the Ianford Site that have been abandoned due to cancellation of projects, change in contractors. or a move of operations. The responsibility for management of these sites is not always clear and as a result, property and materials deteriorate. Three such sites were cleaned up which included: removing excess materials (scrap metal. wood, debris, tumbleweeds, drum liners, etc.), disposing wastes (or appropriately packaged awaiting disposal) and posting signs as necessary. All actions included radiological release surveys environmental compliance reviews, and safety reviews.

RI. Milestone I.I.P-(0)-460, "Complete Closure of Four Abandoned Septic Systems by August 25, 2000" was completed three weeks ahead of schedule. This milestone closed four abandened septic systems to WSDOE requirements on July 28.2000 . This activity included removal of seepage inside the tanks and filling the tanks either with native soil or sand slurry to ensure the elimination of void space within the tanks. This activity supports the $I)($ ) $"$ s commiment to Ecology to bring abandoned, non-compliant septic systems into compliance with state regulation

The $L$ andlord Project managed the Integrated Soil, Vegetation. and Animal Control (ISVAC) Program to maximize performance of the program goals against the priorities, within budget, and to ensure the following objectives are met: 1) safety of employees, public. and environment: 2) to remove/cleanup uncontrolled contamination discovered during environmental surveillances: i) control biological vectors affecting contamination spread: and 4) restore disturbed soil areas to self-sustaining vegetation. Below is a summary of the activities scheduled and completed throughout the year:

Site ('leanup

- 10 Down-postings (391.211 square feet)

- 3Brush Hog (170.57 square fect)

- 3 Surveys and Postings ( 12 miles of transfer lines)

Site Spraying

- CII2M Hill Hanford Group. Inc.: 38 Completed: 19 in Process: 3 continuous

- Dyncorp: 10 Completed; 48 in Process

- Waste Management I lanford: 20 Completed: 10 in Process 
- lase filux lest Facilit!: 3 completed; 2 combunus

- Spent Vuclear Fuels: I completed

- ()ther: 41 Completed; 2 in Process. 7 c'ontinuous

Construction of Project I -292. "Emergency Preparedness ('ontrol Station (LPC 'S)" is complete. The installation of $100 \mathrm{~K} / \mathrm{D}$ Emergency Notification Sirens was completed on schedule in July 2000 and is operational. Redundancies in the electronics will be installed to connect the Emergency (Operations ('enter (EOC) to the sirens. These installations allow the sirens to automatically remain active in the event of a power failure.

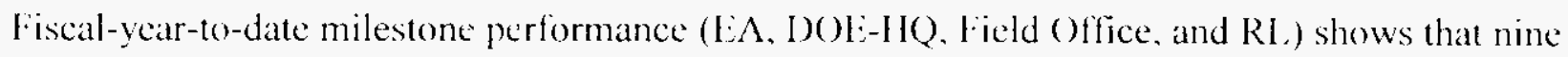
of nine milestones ( 100 percent I were completed ahead of schedule. The Milestone Achievement details. found following cost and schedule variance analysis, provide further information on all milestone types.

\section{ACCOMplishments this Reporting Period}

- Completed RL Milestone I,L.P-00-415, "Project I -309, Replace Section of Main Water Lines (200 Fast)," ahead of schedule on September 28, 2000.

- Completed RI. Milestone 1.L.P-00-405. "Bunker Tank Removal Preparation" fourteen weeks ahead of the scheduled due date of September $29,2000$.

- Completed RL Milestone 1.LP-00-400, "Surveillance/Maintenance. Shutdown, \& Isolation Of Vacant Facilities," eight days ahead of schedule on September 21, 2000.

- Completed RI, Milestone LLP-00-440, "Project L-298. FY 2000 Road Refurbishments," eight days ahead of the scheduled completion date of September 29,2000.

\section{SAFETY}

FY 1999 performance was stable for case rates, but was very unstable in terms of severity (days away and restricted). FY $200($ was stable. 
PHMC Environmental Management Performance Report - November 2000

\section{Section H-Landlord}

16 Lost Away Workday Case Rate

14

(ascsper 20 (a) of) hours

Green

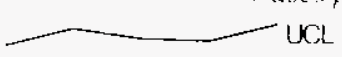

12

10

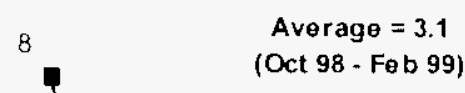

Project Safe Hours $=1,148,080$

FY $1999=1.28$

FY $2000=0.00$

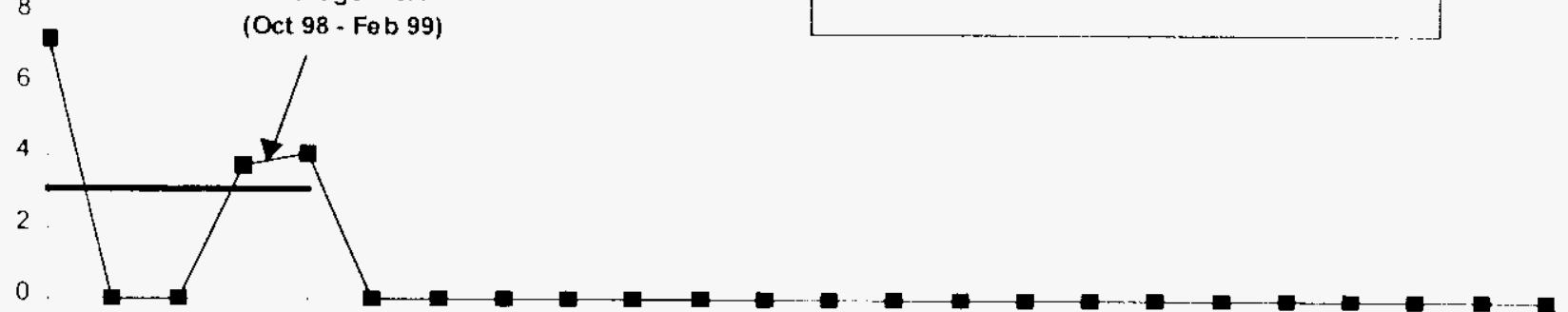

16

14 OSHA Recordable Case Rate

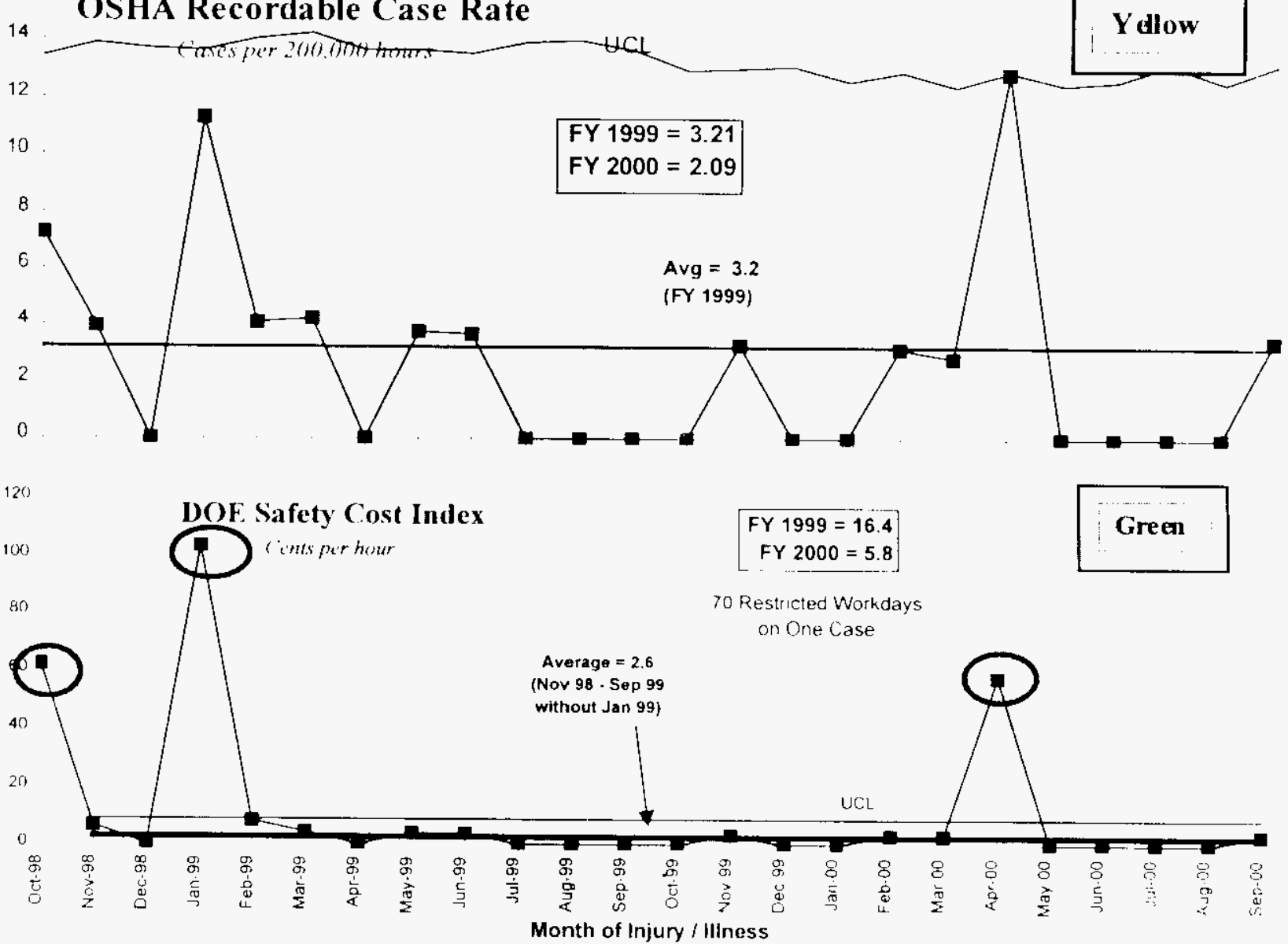




\section{ISMS STATUS}

NoTE: The Infrastructure program includes the I andlord Project and the indirect

Infrastructure. Both of these ar:as are covered under one ISMS program, therefore the ISMS activities described below are for the entire Infrastructure program. which includes I andlord.

- Voluntary Protection Program (VPP) application for status has been submitted to I)()E and the evaluation is expected in November 2000.

- Infrastructure employees achieved another 1 million hours without a lost workday accident. the third time this organization has achieved this significant milestone.

\section{BREAKTHROUGHS / OPPORTUNITIES FOR IMPROVEMENT}

\section{Breakthroughs}

- Continued activities to complete the conversion of Indirect to I Direct. Ihis conversion will support the movement of most infrastructure services into RI, PBS. TP-13, the I andlord Program. With this conversion we will be able to further optimize infrastructure services by integrating normal maintenanee and operations with capital improvement projects.

\section{Opportunities for Improvement}

- The L andlord Master Plan developed basis of estimates, which will validate the baseline in the MYWP.

\section{UPCOMING ACTIVITIES}

- Complete Project L-309. "Replace Main Water Lines" by December 22. 2000.

- Complete installation of a chlorine containment system for Project L.-303, "200 West Area Chlorine Mitigation" by January 31, 2001.

Initiate work on the following projects:

- Project L-340, "Install PliP Backflow Preventors" - FY 2001 Capital Small Project to install backflow Preventors on the two main potable water lines to PFP to resolve cross contamination isstess.

- Project I-3.39. "PFP Water System Isolation-Install Sanitary Water to WRAP" - IY 2001 (iPl' to install a water by pass line around PFP to resolve cross contamination issues with the 200 West Area potable water system. 
- Project 1.-276, "Lmergency Services Rquipment Bay Renovations," - VY 2001 (i]'l' to expand and renovate the existing 200 Area lire Station Kquipment Baly

\section{Cost Performance $(\$ M)$ :}

\begin{tabular}{|l|c|c|c|}
\hline & BCWP & ACWP & VARIANCF \\
\hline Landlord & $\$ 15.3$ & $\$ 13.7$ & $\$ 1.7$ \\
\hline
\end{tabular}

The \$1.7M (11 percent) favorable cost variance is due to a credit to FH's fee base and credit pals: backs for Site Services. L-297, "Equipment Disposition Project," has a new strategy. In lieu of" burial, the railears were sent off site to be recycled. Recycling of the lead in the well cars could not be accomplished in FY 2000 due to moratorium on release of contaminated metals. Further information at the PBS level can be found in the following Cost Variance Analysis details.

\section{SChedule Performance ( $\$ M)$ :}

\begin{tabular}{|l|c|c|c|}
\hline & BCWP & BCWS & VARIANCE \\
\hline Landlord & $\$ 15.3$ & $\$ 16.3$ & $-\$ 1.0$ \\
\hline
\end{tabular}

The $\$ 1.0 \mathrm{M}(6$ percent) unfavorable schedule variance is attributed to the Chlorine Containment System for Project L-303, 200 West Area Chlorine Containment System not being shipped until late October. Further information at the PBS level can be found in the following sichedule Variance Analysis details.

\section{Fy 2000 Cost/Schedule Performance - All Fund Types Cumulative to Date Status - $(\$ 000)$}

FYTI

By PBS

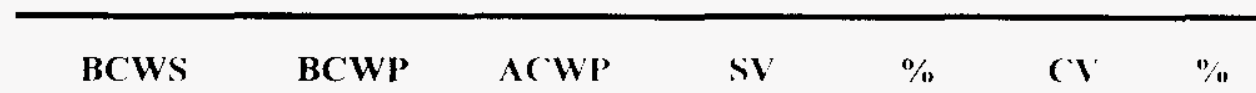

PBS TP13 WBS 1.5 .1

\begin{tabular}{|c|c|c|c|c|c|c|c|c|c|c|c|}
\hline andlord & $\$$ & 16.284 & $\$$ & 15.330 & $\$$ & 1.3 .675 & $\$$ & $(955)$ & $-6 \% \$$ & 1.655 & $11^{0} .0$ \\
\hline & $\$$ & 16,284 & $\$$ & 15.330 & $\$$ & 13.675 & $\$$ & (955) & $-6 \% \$$ & 1.655 & $11^{\prime \prime}$ \\
\hline
\end{tabular}

Note: I andlord final FY 2000 cost was $\$ 13.7 \mathrm{M}$ with $\$ 7.0 \mathrm{M}$ in carryover for a total of $\$ 20.7 \mathrm{M}$ 


\section{COST/SCHEDUle PeRformance Indices (MONTHLY AND FYTD)}

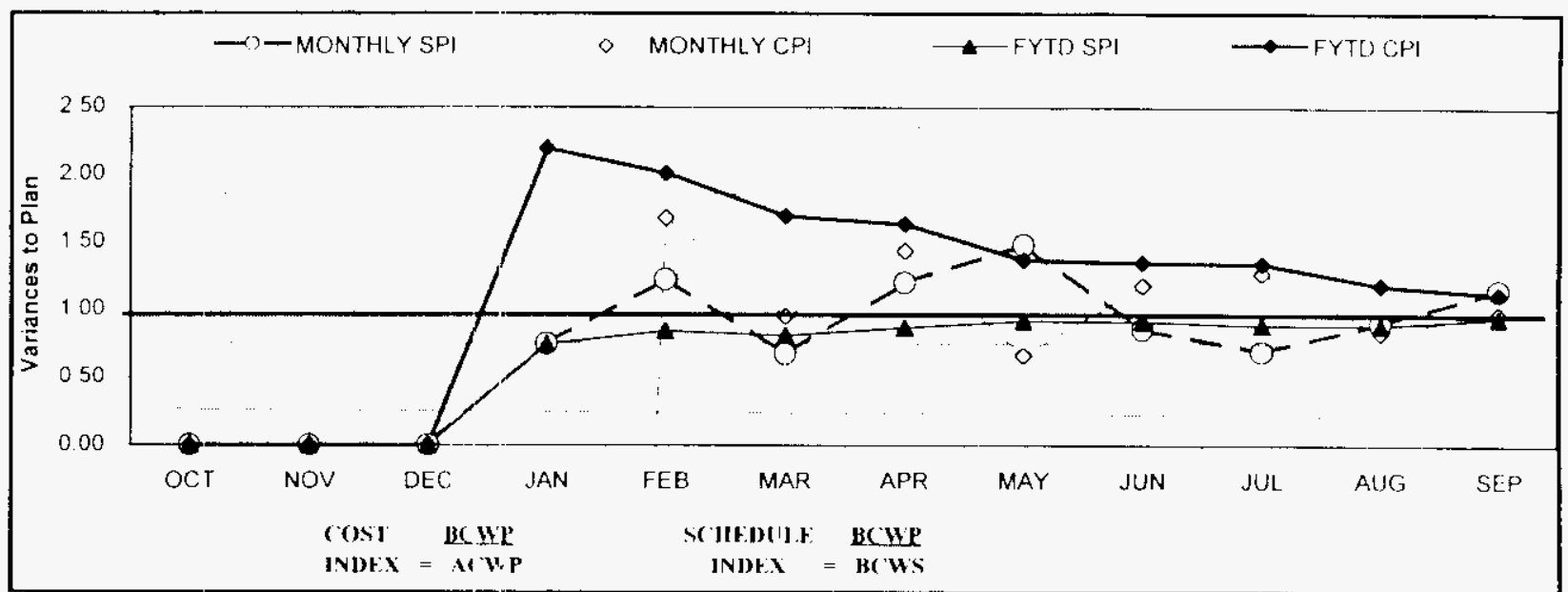

\begin{tabular}{|c|c|c|c|c|c|c|c|c|c|c|c|c|}
\hline FY 2(90) & $(1) \mathrm{T}$ & $\mathrm{YON}$ & DEC & III & FHB & MNR & APR & $\mathrm{MN}$ & Jlix & .11 & Alli; & StP \\
\hline MONIHIIYY SI'I & 0100 & 0.00 & 1910 & 10.75 & 1.22 & 067 & 120 & $1+8$ & (0) 86 & (i) 69 & (1) 40 & 115 \\
\hline MOINIHI Y Cl' & 61.00 & 0.00 & $0(19)$ & -1921 & 168 & (1) 45 & 1.43 & 066 & 118 & 1.27 & 083 & 1).97 \\
\hline 1YYTISSPI & 000 & 0.60 & 0.40 & 0.75 & 0.84 & 0.81 & () 87 & 1192 & 01.91 & 688 & 0.84 & 1)(24 \\
\hline FYII)( & 0.000 & 0.00 & 0.10 & 2.20 & 201 & 169 & 1.63 & 1.37 & 135 & 134 & 118 & 1.12 \\
\hline 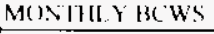 & \$0) & so & 81 & $\$ 3.094$ & $\$ 1.016$ & $\$ 1.269$ & $\$ 1,115$ & $50,5 i$ & $\$ 773$ & $\$ 1.284$ & $3: 812$ & 83.369 \\
\hline$M O N E H . Y H C$ 'WP & $\$ 0$ & sit & Si: & 5:981 & $\$ 1.243$ & $\$ 854$ & $\$ 1334$ & $\$ 468$ & 560,1 & $\$ 8 \times 7$ & $5: 52 x$ & $\sin 608$ \\
\hline$M C+N I T H Y$ Y ACWP & $(\$ 197)$ & \$4 43 & 8767 & $(\$ 155)$ & $\$ 741$ & $\$ 844$ & $\$ 934$ & $\$ 1.464$ & $\$ 561$ & 56098 & $\$ 304 x$ & $\$ 3.972$ \\
\hline FY TD B $3(W \leq$ & .80 & sot & si: & $\$ 3.494$ & $\$ 5010$ & 86.279 & $\$ 7.34 .4$ & $\$ 8.0 .47$ & $\$ 8.820$ & $\$ 10.10 .4$ & $\$ 12.916$ & 516.28 .4 \\
\hline FYTDJ3 $\mathrm{WP}^{3}$ & 80 & sot & $S 1$ & $\$ 2.981$ & $\$ 4.224$ & 55,078 & $\$ 6,417$ & $\$ 7.385$ & $\$ 8.0 .46$ & $5897=$ & 511.462 & $\$ 1<330$ \\
\hline WYit $\mathrm{A}(\mathrm{WP}$ & $(5197)$ & $574 k$ & $5151:$ & $\$ 1,758$ & $\$ 2.1099$ & $\$ 2.998$ & $5 ; .432$ & 85.345 & 55.457 & 8,656 & 89.701 & $\$ 13.675$ \\
\hline
\end{tabular}

\section{Cost VARIance Analysis: $(+\$ 1.7 \mathrm{M})$}

\section{WBS/PBS}

\subsection{1/TP-13 \\ 1...1/1P-13} pass backs for Site Services. 1.-297, "Fquipment Disposition Project," has a new strategy. In lieu of burial, the railcars were sint off site to be recycled. Recycling of the lead in the well cars could not be accomplished in I'Y 2000 due to moratorium on release of contaminated metals. The contract for 1-298. Phase II road refurbishments was awarded later than planned. The work will be completed by the end of November. Real Estate and Site Planning's efforts on the Master Plan were not completed until late September 2000 and invoice costs were not accrued. The cost for demolition of Building 609(' for Project I.-270, "Lmergency Services Renovation." was not as high as planned. The Construction portion scheduled in FY 2001 will be higher than planned. making up the difference.

Impact: The I andlord Project is showing an artificial cost under run. No overall impact. Corrective Action: The remaining funds from FY 2000 will be carried over into FY 2001 to complete the planned work. 


\section{SCHEDUle VARIANCE ANALYSIS: (-\$1.0M)}

\section{WBS/PBS}

1.5.1/TP13

Description/C Containment System for Project 1-303, 200 West Area Chlorine Containment System not being shipped until late October. The loading assembly supplier has not completed fabrication. In addition, the work was deemed plant forces instead of tixed price and the maintenance crew must be scheduled around other priority work like cold weather protection. The lead in two well cars has not been melted down for re-use due to the moratorium on recycled materials. Project I,-270, "Emergency Services Renovation," is behind schedule due to demolition for the 609 ( facility being scheduled at a higher amount than the fixed price contractor had on his schedule and construction of the new building was scheduled lower than the Fixed Price contractor's schedule Impact: No significant impacts.

Corrective Action: None.

\section{FUndS MANAGEMENT \\ FUNDS US SPENDING FORECAST ( $\$ 000)$ \\ FY TO DATE THROUGH SEPTEMBER 2000 \\ (FLUOR HANFORD, INC. ONLY)}

\begin{tabular}{|c|c|c|c|c|c|c|c|c|c|c|c|}
\hline & \multicolumn{3}{|c|}{ Project Completion * } & \multicolumn{5}{|c|}{ Post $2006{ }^{*}$} & \multicolumn{3}{|c|}{ Line tems } \\
\hline & Funds & $\begin{array}{l}\text { Actual } \\
\text { Cost }\end{array}$ & Variance & & Funds & & ctual Cost & Variance & Funds & $\begin{array}{l}\text { Actual } \\
\text { Cost }\end{array}$ & Variance \\
\hline \multicolumn{12}{|l|}{ Multiple Outcomes } \\
\hline \multirow{2}{*}{\multicolumn{12}{|c|}{ 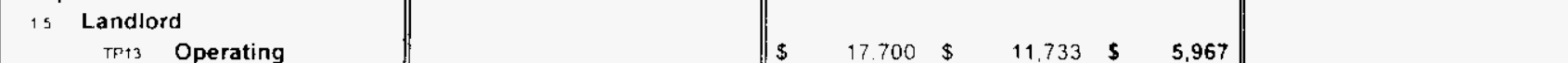 }} \\
\hline & & & & & & & & & & & \\
\hline \multicolumn{12}{|l|}{ Line Item } \\
\hline Total Landlord Operating & & & & 5 & 17,700 & $\$$ & 11,733 & 5,967 & & & \\
\hline Total Landlord Line Item & & & & & & & & & & & \\
\hline
\end{tabular}

- Control Point

\section{ISSUES}

Nothing to report at this time. 




\section{Performance Objectives}

The items listed below are not Performance Incentives. They are performance goals (i.e.. milestones and goals between $\mathrm{FH}$ and the subcontractor).

\begin{tabular}{|c|c|c|}
\hline Outcome & Performance Goals & Status \\
\hline \multirow{6}{*}{$\begin{array}{c}\text { Restore the River } \\
\text { Corridor for } \\
\text { Multiple Uses } \\
\& \\
\text { Transition the } \\
\text { Central Plateau }\end{array}$} & $\begin{array}{l}\text { Replace } 1,200 \text { Feet of } 2 \text {-inch Sanitary } \\
\text { Water Line from } 272 \mathrm{AW} \text { Building Along } \\
\text { Canton Ave. in } 200 \text { Fast }\end{array}$ & Completed construction on September 28,2000 \\
\hline & $\begin{array}{l}\text { Provide Vegetation and Animal Control to } \\
\text { Reduce/Minimize the Spread of } \\
\text { Contamination }\end{array}$ & $\begin{array}{l}\text { Me! performance expectations. } \\
\text { See Accomplishments Section. }\end{array}$ \\
\hline & Legacy Site Cleanup & $\begin{array}{l}\text { Met performiance expectations. } \\
\text { See Accomplishments Section. }\end{array}$ \\
\hline & $\begin{array}{l}\text { Complete Installation of } 100 \mathrm{~K} / \mathrm{D} \\
\text { Emergency Notification Sirens which will } \\
\text { Complete the Total Integration of All } \\
\text { Outside Sirens }\end{array}$ & Completed on schedule in July 20000$)$ \\
\hline & $\begin{array}{l}\text { Complete Emergency Services Renovation } \\
\text { of the } 200 \text { Area Fire Station }\end{array}$ & $\begin{array}{l}\text { Completed all FY } 2000 \text { activities associated with this } \\
\text { project to support conseruction completion by } \\
\text { April 6. } 2001 \text {. }\end{array}$ \\
\hline & $\begin{array}{l}\text { Shutdown Approx. } 20 \text { Vacant Office } \\
\text { Facilities - Deactivate } 25 \text { Vacant Facilities }\end{array}$ & $\begin{array}{l}\text { Met performance expectations. } \\
\text { Sec Accomplishments Section. }\end{array}$ \\
\hline $\begin{array}{l}\text { Put Assets to } \\
\text { Work for the } \\
\text { Fiture }\end{array}$ & $\begin{array}{l}\text { Disposition One Well Car and One Flat Car } \\
\text { - Surveillance and Maintenance of Legacy } \\
\text { Rail Cars at 212R A waiting Disposition }\end{array}$ & $\begin{array}{l}\text { Met performance expectations. } \\
\text { See Accomplishments Section. }\end{array}$ \\
\hline
\end{tabular}

\section{KEY INTEGRATION ACTIVITIES}

- Developed a Long Range Infrastructure Plan, which identifies critical inf rastructure projects needed to support the Site's mission needs. Planning and integration meetings were held with Site programs to fully understand and integrate their reguirements. The information contained in the I.ong Range Infrastructure Plan was later requested hy DOF:-RI. in the form of a Schedule Options Study for Site Infrastructure. and I)( )l:-110 in the form of an Infrastructure Restoration Plan.

- Supported the office of Environmental Management (l:M) in reviewing infrastructure budget and policy issues as part of the Infrastructure Life Lxtension Campaign. The effort might result in an addendum to EM`s FY 2002 budget request to the office of Management and Budget. 


\section{Building Deactivation}

Building Deactivation as of September 30, 2000

80

70

60

50

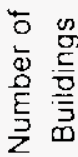

40

30

20

10

0

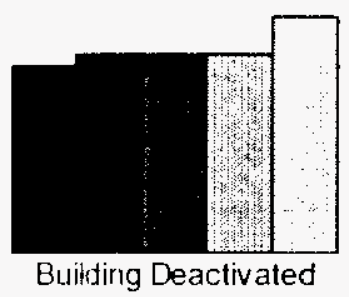

20

21

21

21

25

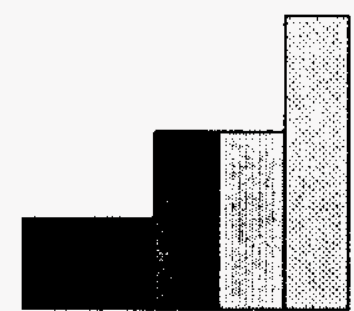

Bidg. Not Yet Deactivated

10

10

19

19

31

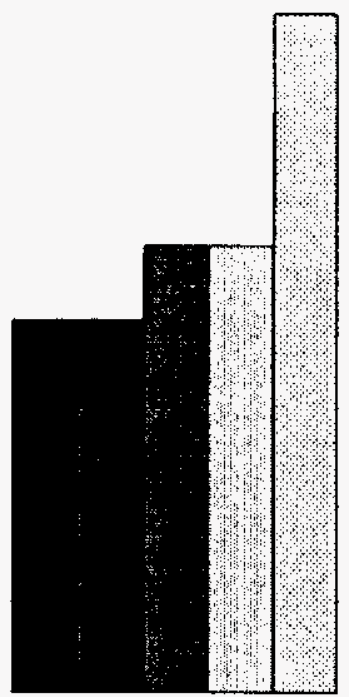

Post Deactivation

39

39

47

47

71

Buildings Deactivated: MORE buildings were vacated in FY2000 than planned. Some of these additional buildings were deactivated because the action was simple and relatively inexpensive. See buildings not yet deactivated for more information.

Buildings Not Yet Deactivated: THESE totals represent buildings in queuc for deactivation. The baseline and planned totals represent the number expected remaining at the end of the year. This is dependent on actions of other projects and is not within landlord control. Comparisons from period to period are not meaningful. Building flow from this category and impact the totals in buildings deactivated and those in post deactivation.

Post Deactivation Monitoring: More buildings were vacated in FY2000) than planned and were deactivated and are now $n$ post deactivation. This includes six huildings that were vacated which did not require deactivation. 
PHMC Environmental Management Performance Report - November 2000

Section H-Landlord

\section{FACILITY DeCOMmISSIONING - CleANUPS}

Facility Decommissiong - Cleanups as of September 30, 2000

25

20

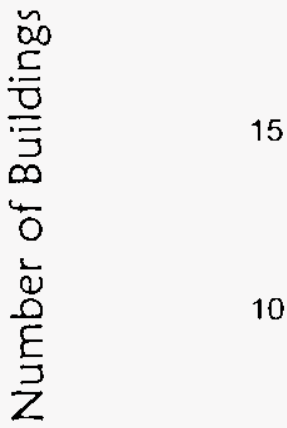

5

0

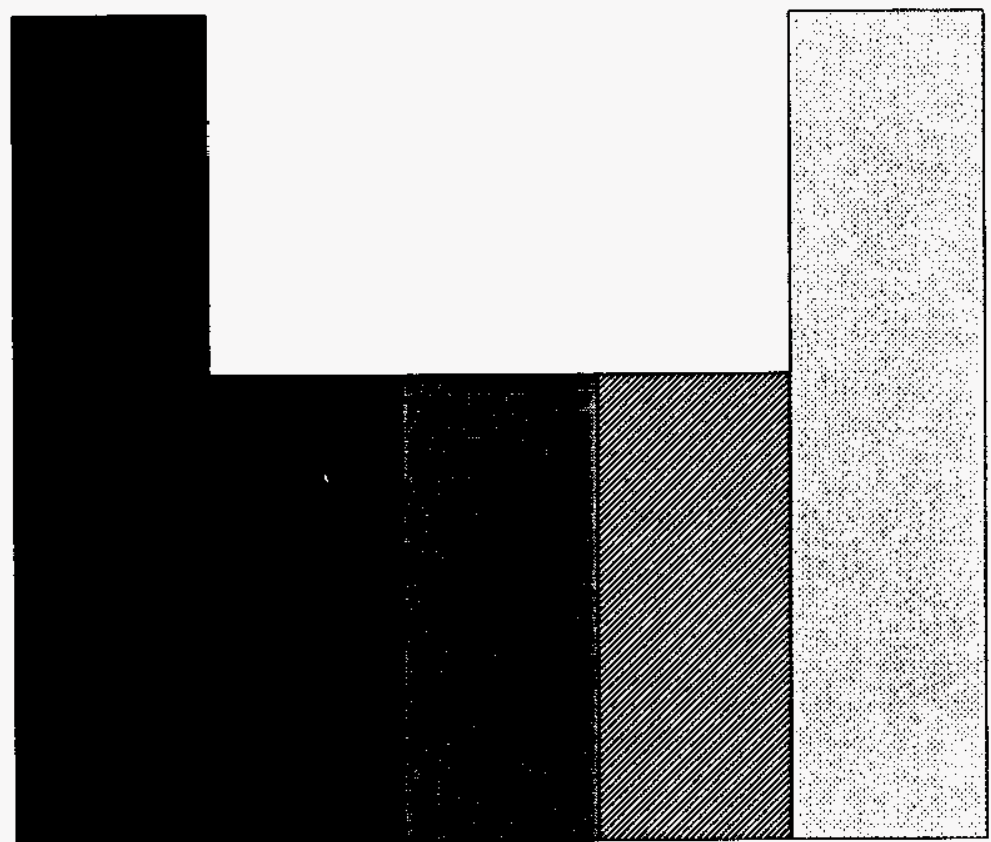

Facility Decommissioning

EFOO MYWP

23

EM Mgnt Comrritmit

13

FY00 Current Baseline

13

圈FYTD Planned

13

$\square^{\text {FYTD Actual }}$

23

Facility Decommissioning: The Landlord Project was able to decommission or remove more facilities than planned because the time and money required to dispose of several facilities was small. 

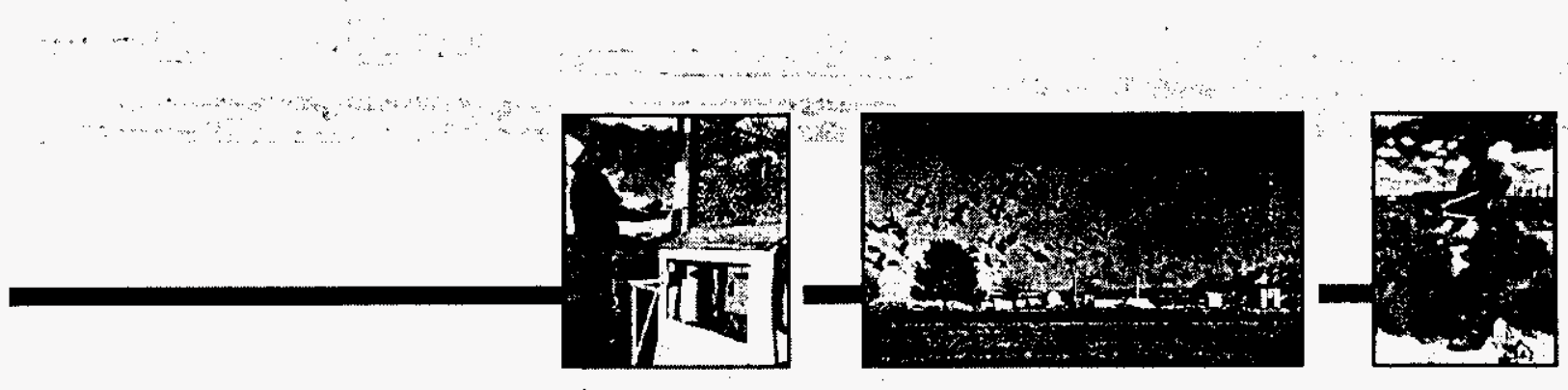

\section{Section I Support}

SP\&I W.W. Ballard, RL G.J. McCleary, FH

SSE W.W. Ballard, RL M.L. Grygiel, FH

ECP S.H. Wisness, RL J.W. Hales, FH

PSRP S.H. Wisness, RL R.L. Dirkes, PNNL

\section{PROJECT MANAGERS}

(509) 376-6657

(509) $372-8385$

(509) 376-6657 (509) 372-2983

(509) 373-9337

(509) 376-4069

(509) 373-9337

(509) 376-8177 


\section{SUMMARY}

Mission Support, Project Baseline Summary (PBS) OTO1 consists of four sub-projects:

- Planning and Integration [Work Breakdown]

- Structure (WBS 1.8.2.1)]

- Systems Engineering (WBS 1.8.2.2)

- Environmental Compliance (WBS 1.8.2.3)

The Environmental Compliance Program is composed of two elements. These two elements were stand-alone programs known as the Hanford Environmental Management Program (HEMP) and the Effluent and Environmental Monitoring Program (EFM) prior to FY99. Although there is a single program. these elements retain their identity on the Integrated Priority List as two separate Units of Analysis.

- Public Safety and Resource Protection (WBS 1.8.2.4)

In addition, Richland Directed Activities, PBS OT04, is included in this section. It consists of general site requirements such as:

- Resource Conservation and Recovery Act [R(RA] Mixed Waste Fee (management fee)

- Department of Health (DOH) Oversight (air monitoring)

- Downwinder Litigation

- Permits/site support [State of Washington (air emissions program)]

- Emergency Preparedness Grants

- State of Oregon Hanford Oversight

- Payment in Lieu of Taxes

- Hanford Advisory Board/Miscellaneous Grants (Hanford Openness Panel)

- Uranium Mass Balance Project (Paducah)

- National Security Analysis (formerly declassification of documents)

- Other minor financial assistance grants and contracts.

NOTE: Unless otherwise noted, the Safety, Conduct of Operations, Milestone Achievement, and Cost/Schedule data contained herein is as of September 30,2000. All other information is as of October 25,2000 unless otherwise noted.

\section{Project Controls}

\section{Top 5 Accomplishments for FY 2000}

- Coordinated and submitted Fluor Hanford Project data for Budget Formulation (IPI.. PPI ss and PBSs), Schedule Options Study support. and Summary Schedule (includes FII, I3H HI, and PNNI, Projects) (Progress).

- Supported significant integration activities such as Budget lormulation (IPI. PPI ss and PBSSs). Schedule Options Study, and Summary Schedule (includes FH. BHI. and PNNI. Projects) (Progress). 
PHMC Environmental Management Performance Report $-N o v e m b e r 2000+10$
Section I-Mission Support

- Ieveloped implemented and managed a process to analyo project performance and cost trends via Fiscal Year Spend forecast to allocatc funds to key clean-up activities and maintain funds within Bukget \& Reporting control points (Progress).

- Delivered FY 2001 MYWP I pdates electronically (Progress).

- Coordinated Performance Nanagement Meetings (Progress).

\section{Additional FY 2000 Accomplishments}

\section{Progress}

- Transitioned from Hanford Site Performane Repot to Environmental Management Performance Report (I:MPR).

- Completed ISMS verification.

- Implemented Project Execution Module to incorporate a significant change in I)()F:-HQ reporting requirements.

- Completed Business Management Oversight Process (BMOP) plan and approach.

- Aligned monthly reports te Site Critical ()utcomes.

- Active and driving participant in $10 \%$ base operations reduction.

- Actively involved in range fire recovery cost analysis.

- Maintained Business Manigement Systems for Hanford Site such as HANIDI, IPARS. IPABS, P3, and PERF.

- Maintained configuration management for Baseline Change Requests for Flour Hanford.

- Submitted execution year performance data via IPARS to DOE-HIQ on a monthly basis.

\section{Systems Engineering and Integration (SE\&I)}

\section{Top 5 Accomplishments for FY 2000}

- Supported the initiative (Schedule Options Study) to develop a viable technical, schedule. and cost baseline for achieving the Ilanford Site Outcomes. SE\&I provided technical baseline information and analyses to support the selection of a preferred option. Sl:\&l also supported several "sub-teams" in developing additional details on specific project level initiatives (Progress).

- Supported the FII initiative (Requirements Initiatives Integration Team [RITI]) to find at least $\$ 30 \mathrm{M}$ in efficiencies in base operations costs to allow RI to fund critical work in FY 2001 and $\mathrm{FY} 2002$. This iniliative has currently found over $\$ 17 \mathrm{M}$ in efficiencies (Progress).

- Supported the lil Accelerating ('leanup leam in developing studies for the 300 Area, the Spent Nuclear Fuels Project, and the Nuclear Material Stabilization Project (Progress).

- Worked with the FII projects to improve and maintain the Hanford Site Technical Baseline Database (HSTD). The HSTD is used to provide integrated technical information for several DOl: products including IPABS-IS. Multi-Year-Work-Plans, Hanford Site Invironmental Management Specification. HANDI, and etc (Progress).

- Lead a workshop on a functional analysis of l ong ferm Resource Management at Hanford (Progress). 


\section{Additional FY 2000 Accomplishments}

\section{Progress}

- Site Level Analyses and Models were used to provide a forecast on the Ianford Site population (by geographic region and by type of work) that tied to the Site Baseline Plans.

- Worked with FII Projects. DynCorp, and BHI to integrate the Waste Site and racility responsibility assignments. Several corrections were made to various systems that were used to feed the IPABS-IS.

- Supported Chemical Management Program in evaluating various systems for mantaging̨ chemical inventory on the Hanford Site.

- Developed a WEB page that demonstrates requirements traceability and flowdown. The WEB page has links to several other WEB sites as well.

\section{Environmental Compliance Program (ECP)}

\section{Top 5 Accomplishments for FY 2000}

- FH proactively maintained compliance with all applicable federal, state. and local environmental statutes and regulations. FH developed permitting and regulatory documents including 4 Resource Conservation and Recovery Act of 1976 (RCRA) Permit Class I Modifications, issued monthly NPDES Reports, lead development of the Hanford Air Operating Permit Supplement Package Application. and issued the 222-S. Part B Application.

Fifty-nine written enforcement actions were input into the Environmental Action Tracking System (EATS) Database. Forty-two have been completed and nine have been closed. More than 30 potential regulatory compliance issues were identified and analyzed. Nine regulatory analysis memorandums were developed to ensure the consistent compliance with regulations across the multiple FH Projects. FH coordinated and supported 50 regulatory inspections and responded to regulator requests. FH acted as the single point of contact for spill and release reporting for all site contractors.

I lanford Site environmental monitoring and reporting was performed for such activities as radioactive discharges, emergency and hazardous chemical inventory, radionuclide air emissions and toxic chemical releases; and six mandated regulatory reports were completed to keep the regulators informed of the status of FH's compliance with the regulations.

Annual site-wide environmental reports were prepared with data compiled from all prime contractors and delivered for issuance to the regulators well before the date required by the regulations.

The National Emissions Standards for Hazardous Air Pollutants reports were provided quarterly as required by the Federal Facility compliance Agreement identifying compliance activities completed during the previous quarter.

To assure that employees are informed of environmental regulations and their maintenance requirements, the NEPA Source Guide was updated and provided to the Site. IHH also maintained the TPA database and public repository information for site use in assuring 
compliance.

The Environmental Action I racking System was improved with changes such as a warning system. reformatted report, and revised desk instructions. This system provides the site with a tool that ensures that regulator requests are responded to on time (Progress).

- Forty enforceable TPA milestones were planned in FY 2000 and all forty were completed with 13 being completed thead of schedule. A TPA change was also successfully negotiated to meet Ecology's regulatery compliance expectations for the Plutonium Finishing Plant repackaging of Rocky Flats ash efforts. The resolution of this compliance issue ensured support for project acceleration (Progress).

- FH established the infrastrueture for the Chemical Management Program that includes all facilities, Industrial Hygiene, Hanford Fire Department. Material Safety Data Sheets (MSI)S), Fmergency Response, Pollution Prevention, Procurement, and Quality Assurance. This allows for a more structured management of the site's chemicals (Progress).

- Timely Support was provided during and after the I lanford fire by collecting air sample filter data and analysis information. Support was also provided for regulator inspection of impacted waste sites. In acldition, the RC'RA contingency plan 15-day report was submitted to Ecology as required (Progress).

- At the January 5.1999 Routine Technical Assistance Meeting (RTAM) with the D()H, ES obtained approval of a revision to the (entral Waste Complex ( $' W($ ) radiation air Notice of Construction (NOC). The revision allows for a reduction of the number of required smears of Nucliil filters, saving the project $\$ 25 \mathrm{~K}$ to $\$ 30 \mathrm{~K}$ per year (Progress).

\section{Additional FY 2000 Accomplishments Progress}

- Completed on or ahead of schedule six (6) mandated Regulatory Reports on Hazardous Chemicals and Dangerous Waste management activities as required under IPPCRA Subtitle B. WAC 173-303, and TSCA.

- Completed and submitted per revised schedule the Annual L.DR Report required under TPA Milestone M-26-01.

- Prepared and issued Reports for Anticipated Costs of TSI) linits (losure and Post-Closure Activities.

- Prepared and issued Annual Reports for llanford Site Environmental Releases, Radionuclide Air Tmissions, and PTRAEU \& HVI Activities, and Quarterly Status Reports for NISSHAP Activities

- Provided Mid-Year Status Reports for NEPA activities on or ahead of schedule.

- Compiled and issued all monthly NPDI:S Reports on schedule.

- Completed all Quarterly RCRA Permit ('lass I Modifications on or ahead of schedule.

- Led lanford Site activities for development and administration of the Llanford Air (Operating Permit Application.

- Prepared and delivered the Ianford Site Air Operating Permil Application Supplement to RI..

- Revised and submitted five (5) RCRA Part A. Form 3 Permit Applications.

- Issued a Part B Application for 222-S that is tailored to become the model for future Hanford Site Part B Permit Applications. 


\section{PHMC Environmental Management Performance Report - November 2000 \\ Section I - Mission Support

- Supported preparation and issuance of the "working draft" R('RA Part B Permit Application for L.L.BC $\mathrm{i}$ and $\mathrm{l}$ Plant.

- Coordinated strategy development, supporting data, and sitewide comments to prepare for a potential appeal of Modification I: Revision to the Hanford Site RCRA Permit.

- Prepared and delivered the Hanford Air/Water Permitting Schedule.

- Provided Support for 111 Facility Inspections and 22 Facility Assessments throughout the year.

- Provided Interpretative Authority for Regulatory Analysis and Review of Proposed Rulemaking and for Environmental Compliance Issues Resolution.

- Prepared several NEPA Supplemental Analyses, which have allowed PFP stabilization activities to continue on schedule.

- Prepared the Surplus Uranium NEPA Environmental Assessment, which resulted in a Finding of No Significant Impact in June 2000.

- Prepared and submitted the DOE Order 435.1 Implementation Plan on schedule.

- Prepared for submittal ORP eight (8) Air Notices of Construction.

- Established an Environment \& Regulation Web Page to disseminate numerous Environmental Laws, Regulations, Policies, Procedures, and contractual Provisions.

- Completed Staff Training on ISMS Core Functions and Guiding Principles

- Supplied a technical expert on radiological air emissions for the DOE (iermantown. MI) office in the FS\&H investigation of their DOE facilities in Oak Ridge. TN and Paducah. KY.

- Sitewide input for the Class 1 modifications of the HF RCRA Permit and for the Ianford Facility Dangerous Waste Permit Application. General Information Portion I)( )L:/RI - -9 ]-28 was coordinated.

- Responses to the LDR Final Determination. TPA M-32 Administrative (Order. EPA MultiMedia Inspection Compliant, and other regulatory and compliance analysis to support formal compliance actions were provided to legal councils and projects.

- Recovery actions for the WSCF Test Method deviation issue and associated sitewide impacts, including.

- issued two status updates for the RCRA Focus Action Plan

- completed sitewide sample-by-sample impact review

- attended response team meetings/briefings

- Twenty Regulatory Environmental Issues Management List (RFIML,) issues including: tank integrity assessments; the TPA Milestone M-32-00 dispute; groundwater; RCRA Corrective Action; I and Dispsal Restrictions, and Hanford Facility RC RA Permit conditions were prepared and reviewed. The REIMI, is a tool to identify and communicate environmental compliance issues for negotiation with the regulators.

- Provided clarifications to benefit facilities regarding Toxic Substances Control Act, including lack of a requirement from EPA on the management of low concentrations $(<50$ ppm) of PCBs.

- A Hanford sitewide comment package was coordinated, developed and submitted on the State Dangerous Waste Amendments.

- Coordination for non-reportable and reportable releases of a hazardous substance and or a petroleum product released to the environment continued throughout the year.

- All Environmental Protection procedures were updated to reflect new and revised requirements as well as FH organizational changes. 
- The Nuclear Materials Stabilization project requested review and comment on an exemption request for a waste stream under the Dingerous Waste Regulations, WA( 173-303 for a state-only corrosivity waste code (WSC2). Commented on the exemption and cautioned that an additional waste code. state-only toxicity (WT02) should also be considered for the exemption request.

- Regulatory analysis and document preparation associated with Plutonium Finishing Plant efforts in interfacing with ficology concerning the effort to start "pipe and go" activities of Rocky Flats $A$ sh by September 5, 2000 were supported.

- Communications between WDOH, 1)OF-RI, and facilities/projects including PFP, WSCF Iaboratory, and T Plant regarding compliance questions, strategies, and permitting associated with radioactive air emission compliance were facilitated.

- Coordination for licology Air technical assistance proposal/workshops and for first technical assistance visits was provided.

- RCRA contingency plan issues were coordinated with Emergency Preparedness in order to resolve bcology concerns. This effort resulted reaching an agreement to close out many issues remaining from the Plutonium Reclamation Facility (PRF) explosion compliance inspection.

- Revisions to all the PHMC Environmental Protection Performance Objectives and Criteria were completed. These INI:-IPs will be used for the Facility Evaluation Board and other environmental assessments. The revisions include regulatory updates as well as incorporate ISMS requirements.

\section{Public Safety and Resource Protection (PSRP)}

\section{Top 5 Accomplishments for FY 2000}

- Significant progress was marle towards the management and protection of the Hanford Site natural and cultural resources through the revision of the Biological Resources Management Plan (BRMaP) and completion of the draft Hanford Cultural Resources Management Plan. Implementation of $B R$ MaP was initiated during the year. Both there resource management plans are critical to the protection of Site resources and will be instrumental in assuring the requirements associated with the Hanford Reach National Monument designation will be met. (Momentum).

- PSERP staff played a major role during the fire that consumed approximately 150.000 acres of the Hanford Site in late Jure. Staff provided key meteorological support to emergency response and lire-tighting teams during the event. In addition, staff provided critical air sampling support and geological, ecological, and cultural resource information during immediatc follow-up and damage assessment activities. Recovery activities include the collection of additional air. soil, and agricultural product samples, ecological surveys, and the replacement of damaged air sampling and meteorology equipment. In addition. plans for reclamation of burned mitigation sites and further resource (cultural and natural) protection were developed. Since the fire. remote sensing and (ils (Geographic Information System) analyses of the burn have been ongoing. Planning for roadside firebreaks was initiated late in F Y 2000 and work will continue into FY 2001 to support DOE on technical aspects of firebreak construction and management. In August, the PS\&RPP received a directive from 1)()l:-RI, to take prioritized. immediate steps to protect public and employee safety and 
rehabilitate critical biological resources and protect cultural resources damaged in the $20 \% 0$ Hanford wild land fire. Cost estimates were prepared for the response to and recovery from the Hanford fire and provided to DOL:-RL. An initial $\$ 75.000$ to cover the cost of these activitics was distributed to PNNL from PBS RL-TP13 in the August financial plan. Staff members initiated steps to respond to this directive. Appropriate actions. as agreed upon with I)(F)-RI to fulfill the directive. will be completed in FY 2000) (Progress).

- PS\&RPP staff was recognized in May for their efforts during the elk relocation that was conducted in March 2000 with Outstanding Performance Awards. The PS\&RPP provided radiological and sample collection support. resources to support the helicopter round-up activity, and Site institutional knowledge relative to elk behavior during the cooperative relocation effort that included the U.S. Fish and Wildlife Service. Washington Department of Fish and Wildlife, and U.S. Department of Energy ('Progress).

- In fulfillment of a DOE policy to conduct periodic (every three years) validation reviews of multi-year work plan (MYWP) baseline cost estimates, a review of the PS\&RPP I:Y 2000$)$ MYWP was initiated by the U.S. Army Corps of Engineers, November 15 and 16. 1999. The Corps review also includes the Environmental Management Program operated by Fluor Ianiel Hanford. Several PS\&RPP staff provided varying levels of support during the November 15 th and 16 th effort, which essentially completes the PS\&RPP component of the review Preliminary discussions with the Corps indicate that there seem to be few issues to resolve on the PS\&RPP MYWP, and that "PNNL was very helpful, knowledgeable and informative." The validation review concluded that the funding for PS\&RPP was consistent with the scope of work defined.

- The Hanford Meteorology Station switched to a personal computer (pc)-based computer network for gathering and processing all of the data from the Hanford Meteorolegical Monitoring Network and other data acquisition activities during December. This system consists of five networked personal computers each with a specific data collection and processing function. Identical data files exist on several of the computers for redundancy. The transition from the IBM RISC/6000 to the pe-based system was seamless, with no interruption in the data gathering process. There is a significant annual cost savings in the pe-based versus the IBM RISC system. MetView (meteorological data viewing) and APGEMS (Air Pollutint (iraphical Environmental Modeling System) software was installed on the HMS computer systems during May. These two software packages were developed for use in the limergency Operations Center. Some HMS-specific modifications to the MetView software were made to make the program more usable to operational meteorologists (Progress).

\section{Additional FY 2000 Accomplishments \\ Progress}

- Cultural Resources Project staff completed the (jable Mountain survey during April. This joint tribal survey was conducted in conjunction with the Hanford Cultural Resources l aboratory and represented the first survey conducted of a sacred site. The approach used. which was developed by the tribal partners, will serve as a model for future surveys of sacred sites

- The final FY 2001 Multi-Year Work Plan (MYWP). PNNI -931-8B and associated Basclinc Change Request bridging the FY 2000 MYWP to the FY 2001 MYWP were submitted to RI for approval on August 30, meeting a Key program milestone (RI.OT(014001). The program funding to be authorized for FY 2001 totals $\$ 6,605 \mathrm{~K}$.

All inputs used to feed the new electronic version of the program's FY 2001 Multi-Year Work 
Plan (MY WP) were pros ided to the liluor llantord, Inc. (FH) database source systems as required by the baseline updating guidance. The inputs included updated MYWP technical narratives, the program's lifecycle cost profiles, milestones, and schedule; and updated Performance Objectives, Measures, and lixpectations (P()MES).

- All projects within the PSR?PP suceessfully weathered the transition into the year 2000) without any significant $\mathrm{Y} 2 \mathrm{~K}$ hugs. Several precautionary activities were conducted in anticipation of potential prohlems and program activities continued into ( $Y$ 2000) seamlessly.

Fiscal-year-to-date milestone performance (LA, DO ():-HQ, and RL) shows that 48 of the 52 milestones (92 percent) were completed on or ahead of schedule and four milestones ( 8 percent) were completed late. The Mulestone Achievement details, found following cost and schedule variance analvsis, provide further information on all milestone types.

\section{AcComplishments This RePORTING PeRIOd}

\section{Project Controls}

- Coordinated and submitted Fluor Manford Project data and provide significant support to integration activities such as Budget Formulation (IPL, PPLs and PBSs), Schedule Options Study, and Summary Schedule (includes FH, BHI, and PNNL Projects).

- Developed, implemented and managed a process to analyze project performance and cost trends via fiscal Year Spend forecast to allocate funds to key clean-up activities and maintain funds within Budget \& Reporting control points.

- Conducted monthly Performance Management Meetings aligned to the Site Critical Outcomes with joint RL/eentractor participation utilizing the workshop environment to enhance site communication and round table discussions including topics such as recognition of significant achievements, risk management (early warnings), issues, tarrier mitigation and opportunities/breakthroughs.

- Completed milestone, SPI-00-002, Assure delivery of FY 2001 MYWP I pdates to RI., on September 22. 2000.

- The deliverable, Monthly 1:MPR was delivered on September 29, 2000

- The deliverable. Submit lipdated 1.8.2.1 MYWP of Final Review/Approval was submitted on September 22, 2000.

\section{Systems Engineering and Integration}

- Worked on an initiative to align the Project Baseline Summaries (PBS) and Work Breakdown Structure (WBS) to the Hanford Outcomes. This work is providing the framework for the Hanford Site Requirements I ocument that is being developed by RI, with support from SLEK.

- Supported a I) ()-HQ workshop on the Stream Disposition Data. The workshop initiated sforts to improve the process and the Integrated Planning, Accounting, and Budgeting System - Information Systen (IPABS-IS). The results will be incorporated into the IIO budget guidanee that will be issued Spring FY 2001.

- Met the BMOP expectations by maintaining the HSTD accuracy at $>99 \%$ and preparing 5 Systems lingineering procedures for approval. 


\section{Environmental Compliance}

\section{Chemical Management}

- The annual briefing to DOE on the status of the ('hemical Management Program (CMP) was presented on September 21, 2000. This briefing satisfies section 5.8 of the Chemical Management Requirements document. DOE had several requests for information. which are currently being gathered.

\section{National Environmental Policy Act of 1969 (NEPA)}

- The Environmental Compliance Program NEPA activities report for FY 2000 and the update to the NEPA Source (suide were issued on September 27, 2000. The issue of these documents completed milestones ECP-00-202 and ECP-(00-203 three days ahead of schedule.

\section{Air Compliance}

- Plans for obtaining the Categorical Air Permit were implemented on September 28. 2000 . This completed milestone ECP-00-407 two days ahead of schedule.

- A meeting was held with Washington Department of Health (WDOH) personnel in ()lympia on September 19th and 20th, which addressed Hanford Site comments on emission source listings contained in the preliminary draft of the Air Operating Permit

- A meeting was conducted with the Hanford Site Central Environmental Committee and the FH Environmental Center of Expertise (ECOE) to discuss the WDOH order received in September 2000 . The order requires that differential pressure gauges used in conjunction with Hanford radiation air abatement systems be annually calibrated or functionally tested. and that lists of these gauges be provided to WIOH by the end of October 2000. The I:COI has proposed that the Hanford Site respond to the WDOH order by providing a list of I)P gauges. The list should be broken down into threc categories: gauges currently on an annual calibration/functional testing schedule, gauges that will convert over to this schedule, and gauges whose schedules will be negotiated with WDOH. $\wedge$ draft response letter reflecting the FCOE has been prepared and distributed for review by affect parties. A "white paper" has also been prepared that evaluates the issue and the possible regulatory bases for WI)( IIIS position.

- ES prepared. for internal review, a draft categorical Notice of Construction (No() to allow for pre-approved entry and surveillance activities in facilities throughout the Hanford Site. In support of this draft, a unit curie offsite dose information was obtained from PNNI. for worst-case releases from each of Hanford's operating areas. One FH facility has already expressed interest in possible use of the NOC for coverage of some planned entry and surveillance activities.

\section{$\underline{\text { RCRA Permit }}$}

- A response was prepared to an Ecology letter requesting additional information for permitting documentation supporting Modification F of the Hanford Facility Resource Conservation and Recovery Act (RCRA) Permit. Ecology requested the additional information by October 11 . 
2000. to perform a completeness review of documentation supporting Modilication l: of the I lanford facility RC RA Pernit. The additional information pertained to the Ianford Facility Dangerous Waste Permit Application. 222-S Laboratory (omplex. Part A. Form 3. Revision 8 and Part B, Revision 1 ( $W \wedge 7890008967$ ): and Hanford facility Dangerous Waste Permit Application, (ieneral Information Portion, 1)( )E/RL,-91-28. The requested information was transmitted to lecology on ()etober 10. 2000.

- licology stated in the September 2000 Permit Steering Committee meeting that licology plans to issue Revision 7 of the RCRA Permit incorporating Modification E by the end of the calendar year. Modification I: includes the Central Waste ('omplex (C'WC) and the Waste Receiving and Processing (WRAP) Facility. It was informally proposed to Ecology that the agency incorporate lessons learned from the 222-S Part B permit negotiations into the ( WC' and WRAP portions of the RCRA Permit. This would further delay issuance of Modification E. but would benefit both acilities. Icology is considering the proposal and a response is anticipated by the end of (retober 2000 .

- Hanford Facility RCRA Permit requirement, Part Il.U.3., requires that piping schematics for dangerous waste underground pipelines shall be maintained in the facility (Operating Record and updated annually, after the initial submittal, with new or revised information. The annual RCRA Permit mapping and marking update information for the lanford Site was completed on September 14,2000. This completed milestone ECP-00-703 one week ahead of schedule.

\section{RCRA Permit Revision and Implementation}

- Environmental Services (ISS) supported a meeting on revising Building Emergency Plans (BEP) for final status units. FS facilitated the resolution of issues with BEPS and completed baseline I3LPs for LERF/F TF and 242-A Evaporator. The new approach will require a review of BE:Ps when DOI:/RL-92-04 is modified. The Hanford Emergency Management Plan. I)()I:RL -92-04, is included as Attachment 4 to the Hanford Facility Dangerous Waste (RCRA) Permit. If Permit nodification forms are required for a DOE/RL-94-02 revision and the revision effects BEPS, permit modification forms will also be completed/submitted for the BEP for each final status TSD unit. Previously when 1)()]:/RL-94-02 was revised the tiers down documents were not reviewed for impacts.

- ES supported meetings/preparation of the new Chapter 8's (training) for final status units for inclusion into the Class 1 modification package.

\section{Inspections/Assessments}

- Regulatory inspections/assessment support was provided at the following facilities:

- On June 14,2000 the State of Washington Department of Ecology started an assessment of the Plutonium Finishing Plant (PFP). The Department of Fcology completed their assessment on September 7,2000. The purpose of their assessment was to determine a baseline of information from which to determine if waste management at PFP was adecuate. if all waste streams had been identified, and to support transition of Pl'P to a deactivated status.

- On September 27, 2000, inspectors from the EPA and the State of Washington Department of Iicology (Ecology) performed an inspection of pre-selected non-regulated waste streams at Hanford. The waste streams were located in three different locations and were being 
collected in 55-gallon drums with "non-regulated" waste labels aftixed to them. I he inspectors provided each facility representative with a "checklist" detailing any concerns or corrective actions necessary. They inspected 4 drums at the new HH:HF Annex (2917-W 3 ) building in the 200 West Area, 3 drums at U-Plant, 1 drum and a locked fenced areal that contained other recycled waste at T-Plant. The inspectors also visited and toured the Consolidated Centralized Recycle Center in the 400 Area.

- On September 27, 2000, inspectors from the 1:PA and Ecology performed a follow-up inspection of the 2714-U waste drums stored at the T Plant Complex. The inspectors met with the ECO and performed a walkthrough of the Mixed (Radioactive) Waste Storage Pad and the 217-T hazardous waste storage building.

- On Tuesday, October 3, 2000 the Washington State Department of Health (WDOL1) visited the 222-S Laboratory to gain a status of the cracking that is occurring on the main stack

- ES performed environmental compliance assessments at the following facilities:

- $\quad 310 / 340$ Complex

- 324/327 Facility

- 200 Accelerated Decommissioning Project facilities

- 300 Accelerated Decommissioning Project facilities

- CWC Complex (sodium)

\section{Crosscutting Compliance/Issue Resolution}

- I and Disposal Restriction (LDR) compliance activities continued during the month. Comments were received from Fcology on the Interim L.JR Report for 2000. and a response from Ecology was received on alleged violation \#4. A strategy for lnterim 2000 I.DR Report comments is being prepared and verbal agreement was obtained from Ecology on the response to alleged violation \#4 in order to close the compliance action.

- ES coordinated the compilation and verification of the status concerning the 'Silver list' close-out forms in response to an Ecology request. Initiated in about 1995. the (Dan) Silver I ist closeout forms identify environmental compliance items and provide documentation of their resolution that might not otherwise exist to support agreement with the regulators.

- Environment and Regulation (E\&R) prepared the regulatory basis for and was involved in a discussion with the IPPA (September 28, 2000) on the continuation of interim status at Hanford.

\section{Project Support (ECP funded)}

- The River Corridor Project requested help in preparing the quarterly Class 1 Permit Modifications for the PUREX Storage Tunnels Part A Permit Application. Changes were proposed and processed in the package transmitted. The training modifications for all final status units were also prepared and included in this quarters Class 1 Quarterly Permit Modification package.

- Environmental function support continued at Plutonium Finishing Plant (PFP) in interfacing Ficology on regulatory matters concerning the transition of PlP to slab on grade. and in developing a response to the Washington State Department of Ecology letter dated September 7. 2000 concerning Ecology`s Plutonium Finishing Plant Assessment Report. 


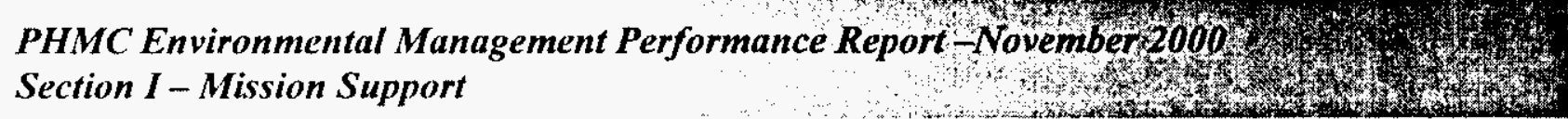

\section{Environmental Notifications and Reporting}

- Regulatory reporting was suordinated for fourteen (14) non-reportable releases of a hazardous substance and /or a petroleum product released to the environment. All of these releases were cleaned up and disposed of per state and federal requirements. There were no reportable events, with a release to the environment. three (3) reportable code noncompliance events reported directly to the regulators. and one (1) event, which required a notification to the regulaturs per a regulatory agreement letter.

\section{Public Safety and Resource Protection (PSRP)}

- PS\&RPP staff made two presentations to DOE-RI mid- and top-level management during September. The presentations provided program and project overviews and FY 2000 accomplishments

- Ecosystem Monitoring Project staff completed the following report: Tiller, B.L,

- L.L. Cadwell, R.K /ufelt. 1. Bender, F. Turner, and G.K. Turner. 2000. "Population ('haracteristics and Seasonal Movement Patterns of the Rattlesnake Hills Elk Herd - Status Report 2000." PNNL, 13331, Pacific Northwest National Laboratory, Richland Washington.

- Honford Site Environmenial Report 1999 was printed and distributed to RL and the public the last week of September, thus fulfilling IO Milestone RIOOTO13003 "Annual Environmental Report to RL and the Public."

- "Collect FY 2000 Envirormental Samples in Accordance with Environmental Surveillance Master Sampling Schedule for CY 1999 and CY 2000 and the Surface Lnvironmental Surveillance Procedures Manual" was completed by $09 / 30 / 00$, thus fulfilling PNNL, Key Milestone RLOT013001 on schedule.

- Project staff (along with the other PS\&RPP projects) provided a SISP overview to D)( I-RI. Office of Site Services staff September 8, and I)OF: Hanford Site managers. September 22, on site surveillance.

- The final copy of Rev 12 of the NEPA (haracterization Document was completed and distributed by 09/29/00. Hard copies were produced as well as electronic copies (placed on a ('ompact I)isc). Rev 12 is, being placed on the Ecology and NIPA websites at PNNI. 'This completes PNNI. Key Milestone RLOT014002, "NEPA (haracterization I)ocument (Rev. 12) Issued by PNNI.."

- The Draft l lanford (ultural Resources Management Plan was delivered to D)(OE-RL on September 29, fulfilling RI. Milestone RLOTO15004.

- The History of the Plutonum Production Facilities at the Manford Site Historic Inistrict, 1943-199(0) was delivered to DOE-RI, on September 29, fulfilling RL Milestone RI.()T015003, "Complele Hanford Site Historic District Book".

\section{ISMS STATUS}

Nothing to report at this time.

\section{BREAKTHROUGHS / OPPORTUNITIES FOR IMPROVEMENT}

Nothing to report at this time. 


\section{UPCOMING ACTIVITIES}

- Revision 3 of the Hanford Site Fnvironmental Monitoring Plan (DOI:RI-9) -50), which is revised every 3 years, is scheduled for completion and distribution in November $20(00$.

- The Annual Benton County Air Authority (BC $\triangle A$ ) Asbestos Notification is due December 31.2000 .

- The Quarterly RCRA Permit ('lass I Modification Notification is due January 2. 2001

- The Quarterly NESHAPS Status report is due January 29.2001.

- The Annual Dangerous Wastes Reports and Tier II Emergency and Hazardous Chemical Inventories are due February 21, 2001.

- Ecology has again delayed issuance of Modification I of the Hanford Facility RCRA Permit (will incorporate WRAP and CWC units), and is now projecting this will occur after January 1, 2001. It has been proposed to Ecology that some of the positive permitting agreements that came out of the recent 222-S Part B Permit application workshops be considered in permit conditions prepared for Modification E. To date, Feology has stated it will consider only the 222-S agreements in finalizing Modification I:.

- Environmental Services will compile hazardous chemical information from the Hanford facilities to prepare the Tier Two Emergency and Hazardous Chemical Inventory Report. which is due February 21, 2001 (Milestone ECP-01-501).

- Environmental Services will compile the dangerous waste generation and waste management activities on site for the Hanford Annual Dangerous Waste Reports, which are due February 21, 2001 (Milestone ECP-01-503).

- The annual Surface Environmental Surveillance Project design review process has been initiated and will culminate with the revision and distribution of the "CY 2000 Hanford Site Environmental Surveillance Master Sampling Schedule" by the end of February 2001.

- Summaries of CY 2000 Biodiversity Plot Monitoring Data and the Sage Brush Die-()ff observed during the previous fiscal year will be completed during March 2001.

- The annual "Climatological Data Summary Report for CY 2000" is scheduled for completion and distribution by the end of May 2001. 
Cost Performance (M):

\begin{tabular}{|l|c|c|c|}
\hline & BCWP & ACWP & VARIANCE \\
\hline Mission Support 1.8 & $\$ 24.7$ & $\$ 25.2$ & $-\$ 0.5$ \\
\hline
\end{tabular}

The $\$(0.5$ million (2 percent) unlavorable cost variance is due to several factors. Further information at the PBS level can be found in the following Cost Variance Analysis details.

\section{SChedule Performance (M):}

\begin{tabular}{|l|c|c|c|}
\hline & BCWP & BCWS & VARIANCE \\
\hline Mission Support 1.8 & $\$ 24.7$ & $\$ 25.5$ & $-\$ 0.9$ \\
\hline
\end{tabular}

The $\$ 0.9$ million (3 percent) unlavorable schedule variance is due to several factors. Further information at the PBS level can be found in the following Schedule Variance Analysis details.

\section{Fy 2000 Cost/SChedule Performance - All Fund Types Cumulative to Date Status - $(\$ 000)$}

FYTD

By PBS

$\begin{array}{lllllll}\text { BCWS } & \text { BCWP } & \text { ACWP } & \text { SV } & \% & \text { CV } & \%\end{array}$

PBSOTOI

WBS 1.8 .2

Mission

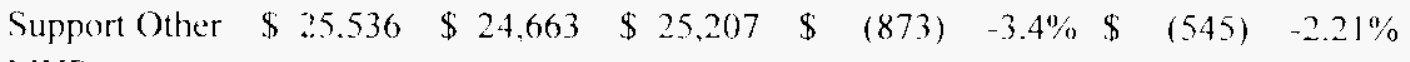
MYPS

Total

$\$ 25,207$

$\$ \quad(873)$

$-3.4 \%$

(545) $\quad-2.21 \%$ 
Cost/Schedule Performance Indices (MONTHLY AND FYTD)

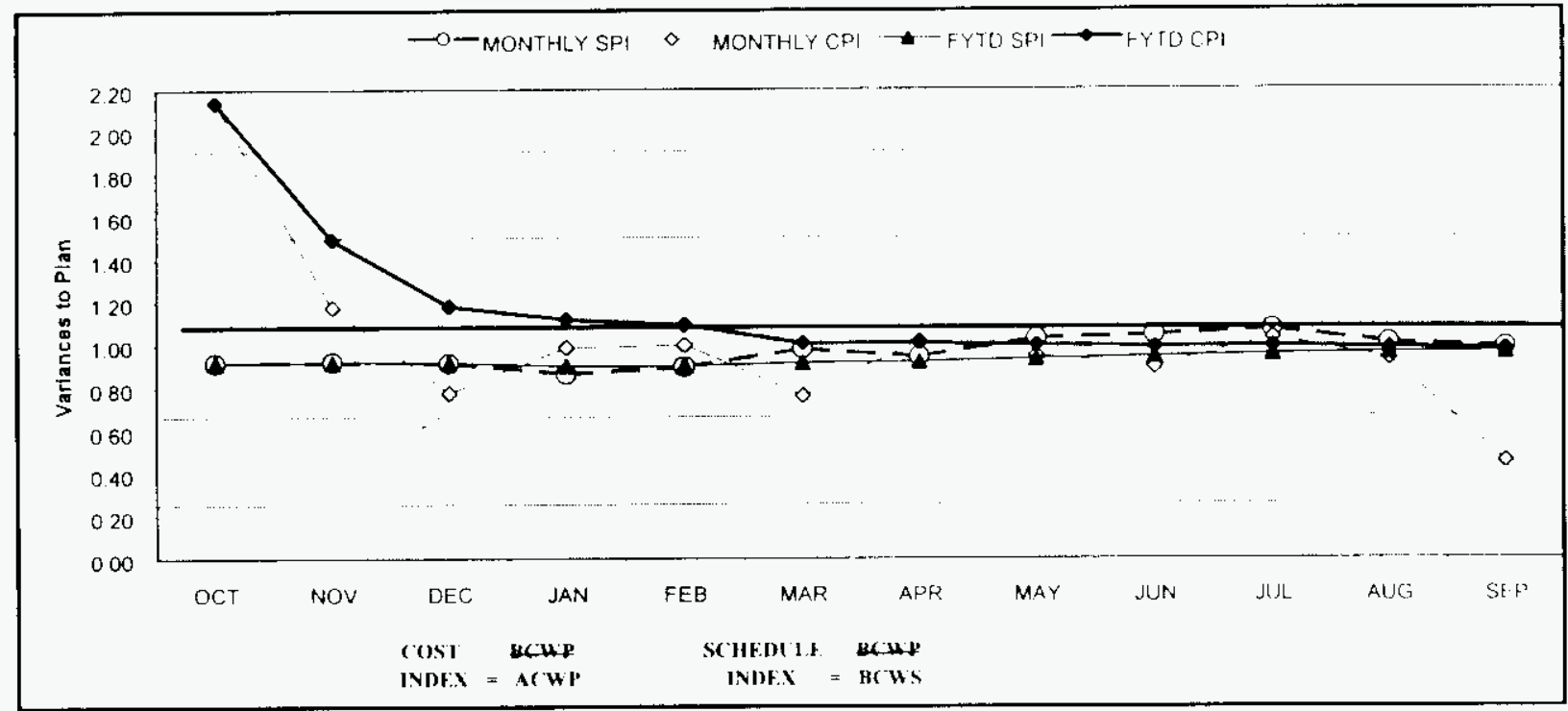

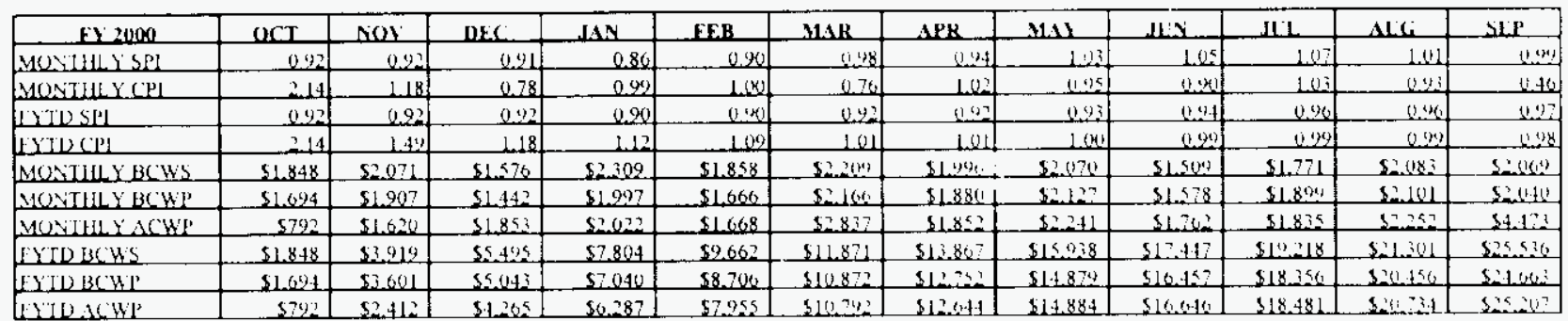

\section{COST VARIANCE ANALYSIS: (\$-0.5M)}

$\underline{\text { WBS/PBS }}$

\section{Title}

\subsection{2/0'T01 Mission Support}

Description/Cause: The $\$ 0.5$ million $(2.2$ percent $)$ unfavorable cost variance is within acceptable reporting thresholds.

Impact: No impact.

Corrective Action: No corrective action required

\section{SCHEDULE VARIANCE ANALYSIS: $(\$-0.9 \mathrm{M})$}

\section{WBS/PBS}

Title

\subsection{2/0T01 Mission Support}

Description/Cause: The $\$ 0.9$ million (3.4 percent) unfavorable schedule variance is within acceptabie reporting thresholds.

Impact: No impact.

Corrective Action: No corrective action required 


\section{FUNDS MANAGEMENT \\ FUNDS US SPENDING FORECAST ( $\$ 000$ ) \\ FY TO DATE THROUGH SEPTEMBER 2000 (FLUOR HANFORD, INC. ONLY)}

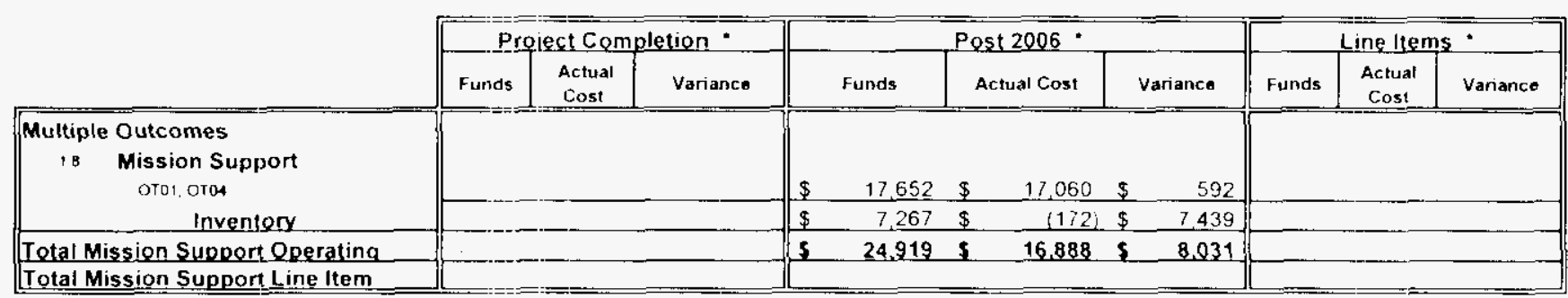

- Control Point

\section{ISSUES}

Baseline Updating Guidance (BUG) - Until RL, provided formal response to several issues lif outlined in its July 18, 2000 letter to RL (Ref: FH-000359A R1, "Fluor Hanford Significant Issues with Baseline Updating (iuidance"), FII was proceeding at risk with the recommendations proposed in the letter.

Corrective Action/Status - Issues were resolved via guidance letters and meetings with RL. 
Baseline Change Requests CurRently in Process

$(\$ 000)$

\begin{tabular}{|c|c|c|c|c|c|c|c|c|c|}
\hline 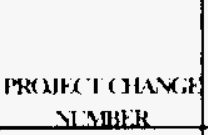 & $\begin{array}{l}\text { DAIt } \\
\text { ofulili }\end{array}$ & HXRUWLE. & 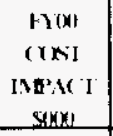 & seces & Itede & 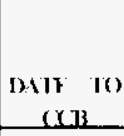 & 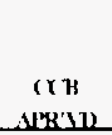 & BL. ABK'LU. & 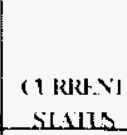 \\
\hline 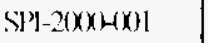 & $1(17799$ & Addition of Paths to ( Josume Range & $\$ 7$ & & & & & & Appowal \\
\hline SIJ'-2(x)(x) $(x) 2$ & $1(x) 2 / x)$ & 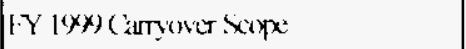 & $\$ 2.18$ & $x$ & $x$ & $23(x)$ & $2 / 3(x)$ & & Aproved \\
\hline $5 y_{1}-2(x)(2-1) 3$ & $11: 5 \times(x)$ & $\begin{array}{l}\text { Bawelinc Moditications to Simpext liscal } \\
\text { Year 2(x) Multi-Yar Work Pan I Txtalle }\end{array}$ & $(5) \leq 3)$ & & & $323(x)$ & $323(x)$ & $5 / 4(x)$ & Appowert \\
\hline Sir- $2(x)(2)(x)$ & $2 / 17 /(x)$ & Moxkling Ioot \& IIY, Mxtule Soope & $\$ 117$ & $x$ & $x$ & $217(\mathbf{0})$ & $217 /(0)$ & $5 / 4(x)$ & Approncal \\
\hline $\mathrm{SP}+2(x)(1)(x) 7$ & $428 / 00$ & $10^{0}$ : Reatuxticn to IYY $2(x) 1.821$ & 8675 & & $x$ & & & & Approvex \\
\hline 1XSR-2Xx(x) (x)1 & & 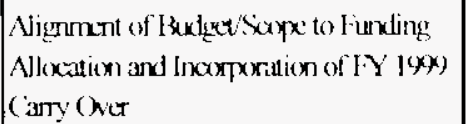 & $\$ 193$ & $x$ & & & & $5 / 4(x)$ & Aproved \\
\hline $1 \times R R_{-} X x \times(x) 2$ & $6 y^{\prime} 13 /(x)$ & 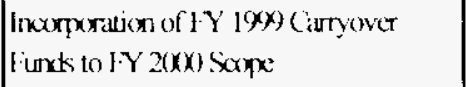 & $\$ 175$ & & & $\sin (x)$ & $622(x)$ & $81(v(x)$ & Aprovical \\
\hline SSi: $-2 x \times(x)(x) 1$ & $1\left(x \sigma^{n} x\right)$ & IY 2000 ) Hridex Change Requxest & $(8 \times 8)$ & & & $11](x(x)$ & $111(1)$ & $126(x)$ & Aprouicil \\
\hline SSI - $20 \times(x) \times 2$ & $1(2 / 8(x)$ & IY 9 (Canyoves & & & & & & & $\mathrm{RH}) \mathrm{A}-\mathrm{F}$ \\
\hline Sis:- $2 x \times(4)$ & $1 / 3 \mathrm{l} /(x)$ & Repriciry lmaxets to Buxcline & & & & & & & 1 ristl \\
\hline SSF : $2 x)(x)(x) 4$ & $7 / 26 / 60$ & FY 200010 IY $2001 \mathrm{BC}$ & & & & & & & (tridt \\
\hline $1 \times\left(x^{3}-2 x\right)(-4 \times) 1$ & $11 / 15 /(x)$ & $\begin{array}{l}\text { Corroctiond/Aligntrent of EXY' } \\
\text { Milestones }\end{array}$ & & & & $11 / 3(k x)$ & $11 / 3(x)$ & $1 / 26 /(0)$ & Anprovex \\
\hline $1:\left(P^{\prime}-2 x\right)(1-1) 2$ & $127(x)$ & $\begin{array}{l}\text { Remove Itrojot W-420) from } \\
\text { linvinmontal (inrplianke Prongam }\end{array}$ & $\mid \$ 1.3(x+1)$ & & & $1 / 5(x)$ & $1:\left(v^{\prime}(x)\right.$ & $2 / 1 /(x)$ & Anprovical \\
\hline $1 \times\left(P^{\prime}-20(x)(0) 3\right.$ & $12 / 15 /(x)$ & $\begin{array}{l}\text { I hilization of } \mathrm{Y}\left(\mathrm{P}^{\prime} \mathrm{FY}-(x) \text { [ noxaded }\right. \\
\text { ('anyover }\end{array}$ & $\$+19$ & & & & & & I nutt \\
\hline$l(x)-2 x)(4) \times 14$ & $2 / 15 /(x)$ & 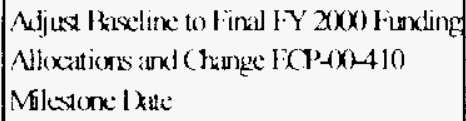 & $\$ 161$ & & & $47(x)$ & $47(x)$ & $510(x)$ & Aprowerl \\
\hline $1:\left(P^{2}-2(x)(x)(x)\right.$ & $418 /(x)$ & 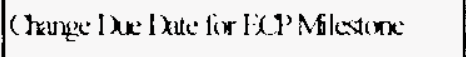 & & & & $5 / 4(x)$ & $54(x)$ & $525(x)$ & Appomial \\
\hline $1 \times\left(I^{\prime}-2(x)(x)(x)\right.$ & $52(x)$ & 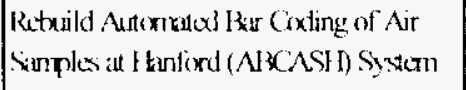 & $\$ 193$ & $x$ & & & & & 1 ristl \\
\hline $1 \times x+2 x)(x)(17$ & $5 / 15 /(x)$ & 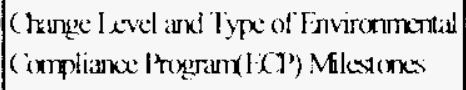 & & & & $531(x)$ & & & Aymusal \\
\hline$[1+2(0) i-(0)]$ & $9 / 12(x)$ & 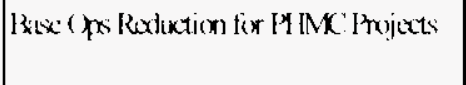 & $-\$ 535$ & & $\mathrm{X}$ & & & & $\begin{array}{l}\text { Ixidl } \\
\text { Ingrearal }\end{array}$ \\
\hline $17+3 x) 1-1 \times 2$ & 92500 & 1Y2(x)! fue Rexuction to $9 \%$ & $-\$ 12 x$ & & & & & & |riali \\
\hline
\end{tabular}


MiLestone ACHIEVEMENT

\begin{tabular}{|c|c|c|c|c|c|c|c|c|}
\hline \multirow[b]{2}{*}{ MLES TONE TYPE } & \multicolumn{4}{|c|}{ FISCAL YEAR-TO-DATE } & \multicolumn{3}{|c|}{ REMAINING SCHEDULED } & \multirow[b]{2}{*}{$\begin{array}{l}\text { TOTAL } \\
\text { FY } 2000\end{array}$} \\
\hline & $\begin{array}{c}\text { Completed } \\
\text { Early }\end{array}$ & $\begin{array}{c}\text { Completed } \\
\text { On } \\
\text { Schedule }\end{array}$ & $\begin{array}{c}\text { Completed } \\
\text { Late }\end{array}$ & Overdue & $\begin{array}{c}\text { Forecast } \\
\text { Early }\end{array}$ & $\begin{array}{c}\text { Forecast } \\
\text { On } \\
\text { Schedule }\end{array}$ & $\begin{array}{c}\text { Forecast } \\
\text { Late }\end{array}$ & \\
\hline Enforceable Agreement & 22 & 3 & 0 & 0 & $\underline{0}$ & 0 & 0 & \\
\hline DOE-HQ & 10 & 1 & 0 & 0 & $\underline{0}$ & $\underline{0}$ & 0 & \\
\hline $\mathrm{RL}$ & 15 & 7 & 4 & 0 & 0 & 0 & 0 & 26 \\
\hline Total Project & 37 & 11 & $4]$ & 0 & 0 & 0 & 0 & 52 \\
\hline
\end{tabular}

Only TPA/I:A milestones and all FY 2000 overdue and forecast late milestones are addressed in this report. Milestones overdue are deleted from the Milestone lixception Report once they are completed. The following chart summarizes the FY 2000 TPA/LA milestone achievement and a Milestone Exception Report follows. The last milestone table summarizes the FY 2001 TPA/liA milestones.

\begin{tabular}{|c|c|c|c|}
\hline \multicolumn{4}{|c|}{ FY 2000 Tri-Party Agreement / EA Milestones } \\
\hline Number & Milestone Title & $\begin{array}{c}\text { Baseline } \\
\text { Date }\end{array}$ & $\begin{array}{c}\text { Actual } \\
\text { Completion } \\
\text { Date/Status }\end{array}$ \\
\hline $1: P-00-302$ & $\begin{array}{l}\text { RCRA Permit Class } 1 \text { Mod Notification Quarter } 1 \\
\text { (For Year 2000-2046) }\end{array}$ & $10 / 01 / 1999$ & $09 / 30 / 1909$ \\
\hline ECP- $-00-702$ & $\begin{array}{l}\text { RCRA RPTS/DOCS Closure/Post Closure Cost Est. } \\
\text { to RL }\end{array}$ & $10 / 22 / 1999$ & $1 0 / 0 6 \longdiv { 1 9 0 9 }$ \\
\hline$E(P-00-901$ & $\begin{array}{l}\text { Issue } 1^{\text {st }} \text { Quarterly NESHAP Status RPT to RL for } \\
\text { EPA }\end{array}$ & $10 / 22 / 1999$ & $10 / 20 / 1999$ \\
\hline$E(P-00-705$ & $\begin{array}{l}\text { RCRA Reports/Does-Annual Permit Status Report - } \\
\text { INEL }\end{array}$ & $12 / 01 / 1999$ & $11 / 29 / 1999$ \\
\hline $\mathrm{F}(\mathrm{P}-00-508$ & $\begin{array}{l}\text { RCRA Section } 3016 \text { Report (Hazardous Waste } \\
\text { Facility }\end{array}$ & $12 / 06 / 1999$ & $1] / 29 / 1999$ \\
\hline $1: P(-00-306$ & $\begin{array}{l}\text { Annual Asbestos Notification of Intent (For Year } \\
\text { 2000-2046) }\end{array}$ & $12 / 31 / 1999$ & $12 / 14 / 1999$ \\
\hline $\mathrm{E}(\mathrm{P}-00-303$ & $\begin{array}{l}\text { RCRA Permit Class } 1 \text { Mod Notification Quarter } 2 \\
\text { (For FY 2000.2046) }\end{array}$ & $01 / 01 / 2000$ & $12 / 16 / 1999$ \\
\hline ECP-00-902 & $\begin{array}{l}\text { Issue } 2^{\text {nd }} \text { Quarterly NESHAP Status RPT to RL for } \\
\text { EPA }\end{array}$ & $01 / 28 / 2000$ & $01 / 17 / 2000$ \\
\hline $1: P-00-701$ & Annual Noncompliance Report to RL & $02 / 17 / 2000$ & $02 / 09 / 2000$ \\
\hline $\mathrm{E}(P-0)(0-503$ & $\begin{array}{l}1999 \text { Hanford Site Annual Dangerous Waste Report } \\
\text { (FY 2000-2046) }\end{array}$ & $02 / 22 / 2000$ & $02 / 22 / 2000$ \\
\hline$[(P-00-50)$ & Tier II Emergency \& Hazardous Chemical Inventory & $02 / 23 / 2000$ & $02 / 23 / 2000$ \\
\hline $1: P-00(-0) 3$ & $\begin{array}{l}\text { Biennial Assess. Of Info. \& Data Access Needs } \\
\text { EPA/ECO }(2000-2046)\end{array}$ & $03 / 31 / 2000$ & $03 / 06 / 2000$ \\
\hline $1:(P-00-801$ & Transmit EISODIS Data to INEEL (FY 2000-2046) & $04 /(01 / 2000$ & $03 / 31 / 2000$ \\
\hline $1:(P-00-802$ & $\begin{array}{l}\text { Issue Annual Von-Radioactive Airborne Emissions } \\
\text { Report (FY 2000-2046) }\end{array}$ & $04 / 01 / 2000$ & $03 / 31 / 2000$ \\
\hline $1:\left(P^{\prime}-00-304\right.$ & $\begin{array}{l}\text { RCRA Permit Class I Mod Notification Quarter } 3 \\
\text { (For FY 2000-2046) }\end{array}$ & $04 / 02 / 2000$ & $3 / 29 / 2000$ \\
\hline
\end{tabular}


PHMC Environmental Management Performance Report-November 2000 Section I-Mission Support

\begin{tabular}{|c|c|c|c|}
\hline \multicolumn{4}{|c|}{ FY 2000 Tri-Party Agreement / EA Milestones } \\
\hline Number & Milestone Title & $\begin{array}{l}\text { Baseline } \\
\text { Date }\end{array}$ & $\begin{array}{l}\text { Actual } \\
\text { Completion } \\
\text { Date/Status }\end{array}$ \\
\hline $\mathrm{E}(\mathrm{P}-00-904$ & $\begin{array}{l}\text { Issue } 3^{\text {rd }} \text { Quarterly NESHAP Status Report To RL } \\
\text { for EPA }\end{array}$ & $04 / 212000$ & $0.4 / 0.4 / 2000)$ \\
\hline FC(P-00-307 & Submit Implementation Plan & $0.5 / 15 / 2000$ & $05 / 15 / 2000$ \\
\hline$E(P-00-803$ & $\begin{array}{l}\text { Issue Annual Radionuclide Air Fmissions Report } \\
\text { (For FY 2000-2046) }\end{array}$ & $06 / 15 / 2000$ & $06 / 152000$ \\
\hline ECP-00-410 & $\begin{array}{l}\text { Annual PTRAEU Report to DOE-RL (For FY 2000- } \\
\text { 2046) }\end{array}$ & $6 / 15 / 2000$ & $06 / 142000$ \\
\hline $1:(P-00-502$ & $\begin{array}{l}\text { EPCRA Section } 313 \text { Toxic Chemical Release } \\
\text { Inventory }\end{array}$ & $06 / 23 / 2000$ & $06 / 21 / 2000$ \\
\hline$\because(P-00-504$ & Annual PCB Document Log - June & $06 / 23 / 2000$ & $00,22 / 2000$ \\
\hline ECP-(00-305 & $\begin{array}{l}\text { RCRA Permit Class I Mod Notification Quarter } 4 \\
\text { (For FY 2000-2046) }\end{array}$ & $(07 / 02 / 2000$ & $06 / 26 / 2000$ \\
\hline $1:\left(P^{\prime}-00-507\right.$ & Annual LIR Report (M-26-(1) & $07: 21 / 2000$ & $07 / 21 / 2000$ \\
\hline $1: C-00-906$ & $\begin{array}{l}\text { Issue } 4^{\text {th }} \text { Quarterly NESHAP Status Report to RL for } \\
\text { FPA }\end{array}$ & $07 / 28 / 2000$ & $0 7 / 0 5 \longdiv { 2 0 0 0 }$ \\
\hline $1: C P-00-804$ & Annual Report on Environmental Releases & $08 / 31 / 2000$ & $08 / 30 / 2000$ \\
\hline $\mathrm{ECP}-00-703$ & $\begin{array}{l}\text { Coordinate RCRA Pipe Mapping and Marking (For } \\
\text { FY 2000-2046) }\end{array}$ & $09 / 21 / 2000$ & $09 / 1+/ 2000$ \\
\hline $1: C P-00-704$ & Submit Revision of 91-28 & $09 / 30 / 2000$ & $08 / 29 / 2000$ \\
\hline ECP- $-00-301$ & $\begin{array}{l}\text { RCRA General Facility Inspections (For FY 2000- } \\
2046 \text { ) }\end{array}$ & $09 / 30 / 2000$ & $00 / 28 / 2000$ \\
\hline \multicolumn{4}{|c|}{ DNFSB Commitments } \\
\hline & to report at this time. & & \\
\hline
\end{tabular}

\section{MILESTONE EXCEPTION REPORT}

\section{Overdue - 0}

\section{FORECAST LATE - 0}

\begin{tabular}{|c|c|c|c|}
\hline \multicolumn{4}{|c|}{ FY 2001 Tri-Party Agreement / EA Milestones } \\
\hline Number & Milestone Title & Baseline Date & $\begin{array}{l}\text { Actual } \\
\text { Completion } \\
\text { Date/Status }\end{array}$ \\
\hline $1:(P-0 \mid-90]$ & $\begin{array}{l}\text { Issue Quarterly NESHAP Status Report to RI. } \\
\text { for EPA }\end{array}$ & $10 / 20 / 2000$ & \\
\hline $\mathrm{ECP}-0) 1-902$ & $\begin{array}{l}\text { Issue Quarterly NESHAP Status Report to RI. } \\
\text { for LPA }\end{array}$ & $129 / 2001$ & \\
\hline $\mathrm{I}(\mathrm{P}-0) 1-904$ & $\begin{array}{l}\text { Issue Quarterly NESHAP Status Report to RI } \\
\text { for EPA }\end{array}$ & $42 / 2001$ & \\
\hline $1:(P-0) 1-906$ & $\begin{array}{l}\text { Issue Quarterly NESHAP Status Report to RI. } \\
\text { for EPA }\end{array}$ & $8 / 312001$ & $\cdots$ \\
\hline \multicolumn{4}{|c|}{ DNFSB Commitments } \\
\hline & Nothing to report at this time. & & \\
\hline
\end{tabular}




\section{Performance Objectives}

Nothing to report at this time.

\section{KEY INTEGRATION ACTIVITIES}

Specific components of the l'S\&RP Program are identified as a critical core project within the Groundwater/Vadose Zone Integration Project. As such, key activities relevant to both programs were integrated into FY 2001 detailed work plans as appropriate. 
PHMC Environmental Management Performance Report - November 2000

Section J-National Programs
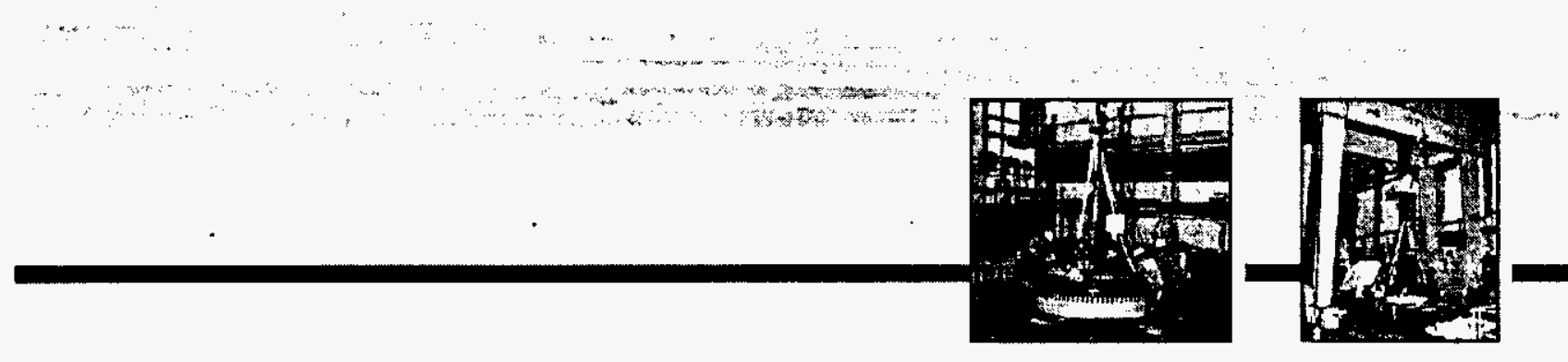

Section J

National Programs 


\section{SUMMARY}

I)(OE ISM is responsible for a variety of National Programs. I)()I-H() typically provides operations policy and programmatic guidance to one or more field office that serve as lead for individual programs. FH currently supports the following National Programs: Transportation and Packaging (PBS OTO2) and Pollution Prevention and Waste Minimization (PBS WMO7).

Transportation and Packaging provides full-service transportation and packaging capabilities. Packaging services for radioactive and hazardous cargo is provided. including regulatory safetybasis documentation, certification, and licensing. Packaging plans and logistical studies for major shipping campaigns are also provided, as well as approved training courses in transportation safety and waste management. Transportation and traffic logistics management. engineering and operational support to offsite customers, carrier selection and evaluation. automated transportation management systems used by the I I.S. Department of Energy (I)()I:) complex and commercial vendors, and international transport of hazardous and radioactive packages are other services provided.

Pollution Prevention and Waste Minimization (P2/WMin) coordinates the development and implementation of a Hanford Site P2/WMin Program to comply with Federal, state. and I)( )f directives. The program's purpose is to achieve Site objectives through effective and efficient methodologies tailored to generator activities and operations.

\section{Top 5 Accomplishments for FY 2000}

The Sitewide Cost Savings/Avoidance for the Ianford Site this fiscal year was over forty-seven million dollars (\$47M) (Progress).

The site accomplished a waste avoidance (routine and non-routine) of over 180.000 cubie meters of low level waste/mixed low level waste, over 26,000 metric tons of Hazardous waste, and wer 1,500 metric tons of Sanitary waste. The purchase of EPA designated products containing recycled content was 98.3 percent (Progress).

The Hanford Site received three DOF Pollution Prevention Awards: 1) Domma Merry for Model Facility, 2) Public Outreach, and 3) Sowing the Seeds for ('hange. Hanford Site also won the Washington State Iepartment of Ecology Recycling Award (Progress).

This fiscal year Pollution Prevention/Waste Minimization implemented nine Pollution Prevention high Return on Investment (ROI) projects with a savings/avoidance of $\$ 23 \mathrm{M}$ and waste reduction of over 150,000 cubic meters at a cost $01 \$ 1.309$ million (Progress).

Thirteen projects on the site were implemented with a project cost of $\$ 1.9 \mathrm{M}$ and savings/avoidance of $\$ 8.1 \mathrm{M}$. with a potential waste reduction of 11.950 cubic meters (Progress). 


\section{Additional FY 2000 Accomplishments}

\section{Progress}

The ( leanup/Stabilized Waste Avoided goal to reduce all waste by 10 pereent $(1.920 \mathrm{~m} 3$ ) was exeeded. The documented waste was reported at $7.280 \mathrm{~m}$; through various processes and uses.

The updated Safety Analysis Report Packaging (SARP) HNF-SD)-TP- SARP-017. Rev.2, for (Onsite) Multi-Canister Overpack (ask was completed and issued to Rl. April 12, 2000 .

Six Transportation and Packaging Project I Ianford Management System Procedures have been updated and issued.

HII T\&P Program (Office received a thank you from R1, for the excellent work completing the Engineering Change Notice to the I ead Lined I rum Safety Analysis Report for Packaging (SARP) in a timely and efficient manner. The revisions to the safety analysis for the tie-down and (ras (ieneration sections of the SARP were well done and of high quality. The $D O H$ Authorization Basis Division (ABD) review of the $\mathrm{E} C \mathrm{C}$ was easier.

Efforts continued in the development of the Hanford Site Minimum Packaging Requirements (MPR) with RL. The intent of the MPR is to establish an equivalent baseline of requirements for on-site shipments (similar to 10 CFR 71) for future development of SARP/SEP's. Once these criteria have been established and approved by RL, the MPR will reduce the review and approval process for SARP/SI:P'S.

\section{AcComplishments this Reporting Period}

- A preliminary review of the PHMC LI,W, MLLW, and hazardous waste generation numbers for September and FY 2000 was completed. The data reviewed to date indicates that the PIMC met the FY 2000 waste reduction goals. PNNI generated approximately $27 \mathrm{M} T$ less of Hazardous Waste (HAZ) then in $\mathrm{rY} 99$ as a result of various actions taken in the past few years to minimize HA7, waste generated (i.e.. Pollution Prevention ()pportunity Assessments, Return on Investment (ROI) implementation, material substitution, and inventory reduction). SAN, LI,W and MI.L.W waste reductions resulted from recycling. ROI implementation, and source reduction.

- The fourth quarter FY 2000 meeting was conducted September 25, 2000. Presentations made included a brief discussion of the technical serviees and training available: an overview of the PIP Safety and P2/WMin program; a $33 \mathrm{HI}$ presentation on the procurement and field use of the RoI funded freo Physical Probe; the IYY 2001 site goals; and draft revision \#5 to the I lanford Site Waste Minimization and P2 Awareness Program Plan.

- In responce to a DOO :-HOQ request, forecast numbers for shipping containers (i.e. drums, boxes, ete.) required by the site for the next 35 years was given to the DOl:-RI. P2/WMin Program Manager. 


\section{FY 2000 Cost/Schedule Performance - All Fund Types Cumulative to Date Status - $(\$ 000)$}

FYTI)

By PBS

PBSSOTO2 Transportation \&

WBS 1.11.1 Packaging (RI. 7601)

PBS WM07 Waste Minimization

WBS I.11.2 (RI.HQ 7770)

Total

\begin{tabular}{lllllll}
\hline BCWS & BCWP & ACWP & SV & $\%$ & CV & $\%$
\end{tabular}

$\begin{array}{lllllllllll}\$ 2,319 & \$ 2.485 & \$ 1,930 & \$ 160 & 7 \% & \$ & 555 & 220 \%\end{array}$

$\begin{array}{lllllllll}\$ 3.681 & \$ 3.681 & \$ 2.402 & \$ & (0) & 0 \% & \$ 1.279 & 35 \%\end{array}$

\section{Cost/Schedule Performance Indices (MONTHLY AND FYTD)}

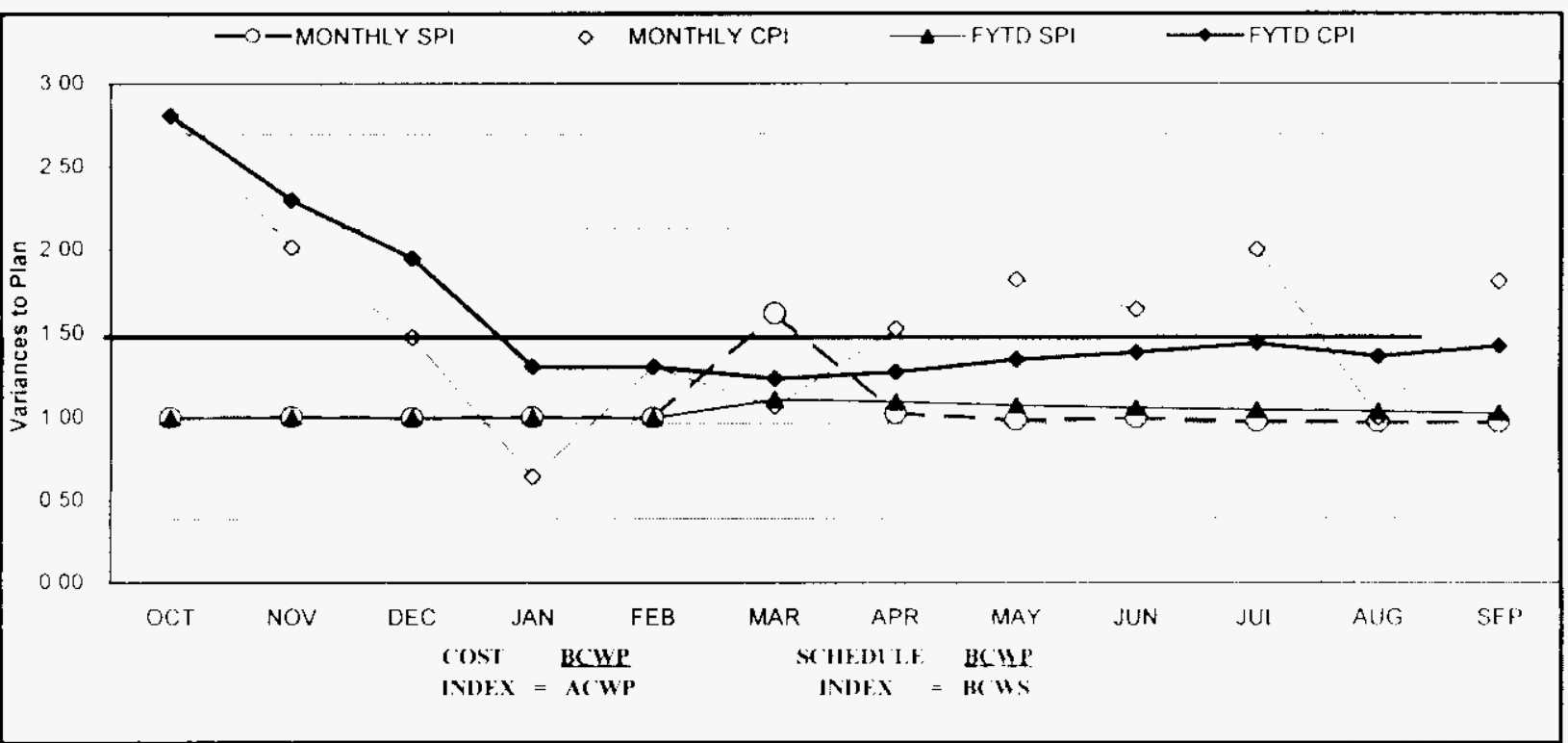

\begin{tabular}{|c|c|c|c|c|c|c|c|c|c|c|c|c|c|c|c|c|c|c|c|c|c|c|c|}
\hline$+121 \times 00$ & \multicolumn{2}{|c|}{$0(1$} & \multicolumn{2}{|c|}{$\mathrm{NOS}$} & \multicolumn{2}{|c|}{ DFC } & \multicolumn{2}{|r|}{ JAN } & \multicolumn{2}{|r|}{ FEB } & \multicolumn{2}{|r|}{ MAR } & \multicolumn{2}{|r|}{ Al'K } & \multicolumn{2}{|r|}{11.11} & \multicolumn{2}{|r|}{$J 11$} & \multicolumn{2}{|r|}{ J!。 } & 116 & \multicolumn{2}{|r|}{ SF' } \\
\hline AgON[H]YY Y & & $\mathrm{I}(\mathrm{H})$ & & 1.00 & & 100 & & 1.00 & & 100 & & 10,2 & & 1118 & & 0.98 & & $16 n$ & & (1) & $(11)^{-}$ & & it 1, \\
\hline Mosilli Y Cll & & 281 & & 2011 & & 1.48 & & 0.65 & & 1.30 & & $10 ?$ & & 153 & & $18 ?$ & & 164 & & $\therefore(x)$ & 16 (ii) & & $|x|$ \\
\hline 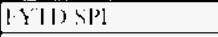 & & 1.00 & & 100 & & 100 & & 1.00 & & 100 & & 111 & & $116 !$ & & 107 & & $1\left(i t_{1}\right.$ & & 105 & 10.4 & & 101 \\
\hline MONIHIYHCWS & $\$$ & 304 & 3 & 38.5 & $\$$ & 328 & $\$$ & 324 & $\$$ & 324 & $\$$ & $i(3)$ & 8 & 38 & $\$$ & 611 & $\$$ & 674 & $s$ & 501 & $6=5$ & $s$ & $10<i$ \\
\hline $\mathrm{MCNHHI}$ YBCW? & $s$ & $30:$ & $\$$ & 381 & 8 & 328 & 5 & 330 & $\$$ & 324 & 5 & 589 & 8 & (1) & $s$ & $t, 01$ & 8 & $6 ? 2$ & $s$ & 5.48 & $65^{\circ}$ & 3 & 10124 \\
\hline MUNIHIYACW & $s$ & $10 x$ & $\$$ & 131 & $\$$ & 222 & 5 & 512 & $\$$ & 249 & 8 & 5.17 & 3 & $20 x$ & $\$$ & $i 3 !$ & $\$$ & $4(49$ & $s$ & 274 & $65^{-}$ & 5 & 9615 \\
\hline YYIIIBCWS & 5 & 30.4 & $s$ & $68 ?$ & 8 & 1.015 & $\$$ & $1,3.45$ & $\$$ & $1.666^{6}$ & $\$$ & 2016 & $\$$ & $\therefore 4 . \mathrm{K}$ & 8 & 3,034 & $\$$ & $3,71.1$ & $s$ & 4.274 & 5.44 .44 & 8 & $0.114 x-1$ \\
\hline 1.113Ho Kl? & $s$ & 303 & $s$ & 687 & 8 & 1.015 & $\$$ & 1.345 & $\$$ & $1,6(6,9)$ & $\$$ & 2.25 .4 & $s$ & $\therefore \operatorname{ton}:$ & $\$$ & $i . .7 t-1$ & $\$$ & 993 & $s$ & 4.485 & 5514. & $\$$ & (1. In: \\
\hline IYIJ) A(WP & 5 & 108 & 5 & $2(x)$ & $\$$ & 521 & 5 & 1.033 & $\$$ & 1.282 & 5 & 1829 & 9 & $\therefore(6) t_{1}$ & 5 & $\therefore .122$ & 5 & $25 \div 6$ & $s$ & $3.11: 1$ & $s: 7,2$ & 8 & $\therefore 3$ \\
\hline
\end{tabular}




\section{COST VARIANCE ANALYSIS: $(+\$ 1.8 \mathrm{M})$}

\section{$\underline{\text { WBS/PBS }}$}

1.11.1/OT02
Title

Transportation and Packaging

Description and Cause: The $\$ 555 \mathrm{~K}$ (22 percent) favorable cost variance is due to a major change in the Motor (arrier Fvaluation Program (MCEP) that resulted in no activities being done. When the revision is complete. MCFP field audits will resume, increasing both travel and labor costs. At the request of the customer, the Automated Transportation Management System/Enterprise Transportation Analysis System (ATMS/ETAS) integration project wall not be started until FY 2001.

Impact: None.

Corrective Action: None.

\subsection{2/WM07 Pollution Prevention/Waste Minimization}

Description and Cause: The $\$ 1,279 \mathrm{~K}$ (35 percent) favorable cost variance is due to staffing shortfalls in first half of year.

Impact: None

Corrective Action: Under-runs will be utilized to offset funding shortfall in Fiscal Year 20(01.

\section{SCHEDULE VARIANCE ANALYSIS: $\quad(+\$ 0.2 \mathrm{M})$}

\section{WBS/PBS $\quad \underline{\text { Title }}$}

1.11.1/OT02 Transportation and Packaging

Description and Cause: The $\$ 166 \mathrm{~K}$ ( 7 percent) favorable schedule variance is due to program efficiencies and is within established thresholds.

Impact: None.

Corrective Action: None.

\section{FUNDS MANAGEMENT FUNDS US SPENDING FORECAST $(\$ 000)$ FY TO DATE THROUGH SEPTEMBER 2000 (FLUOR HANFORD, INC. ONLY)}

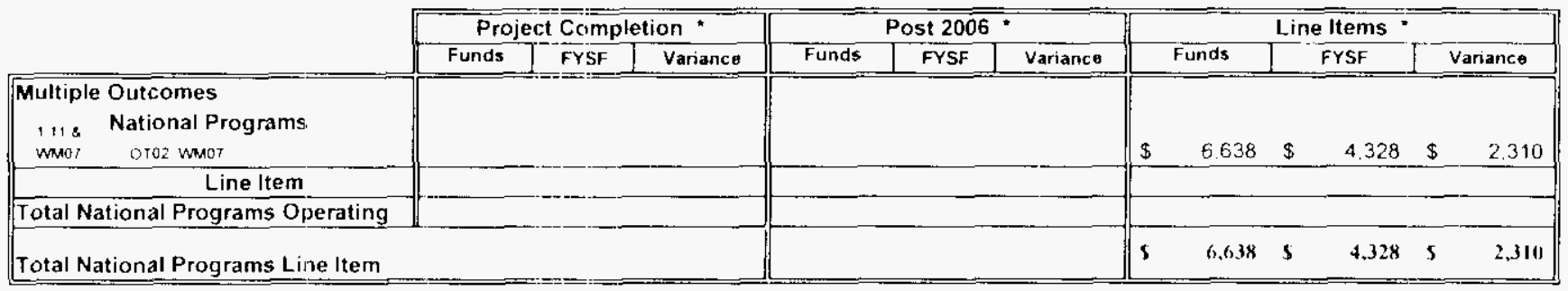

* Control Point 


\section{Richland Operations Office \\ Environmental Restoration \\ Environmental Management Performance Report}

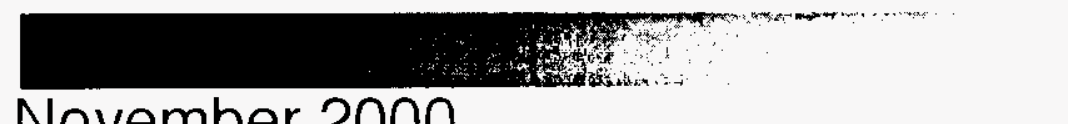

November 2000



Focused on Progress...

Focused on Outcomes!
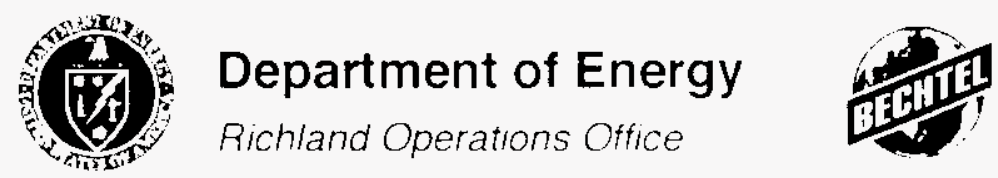

Bechtel Hanford, Inc.

Environmental Restoration Contractor 


\section{TABLE OF CONTENTS}

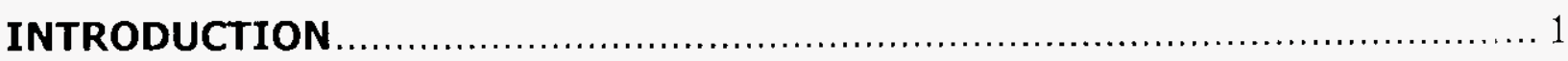

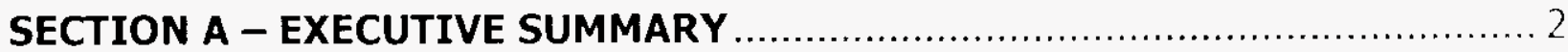

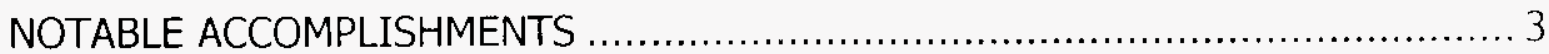

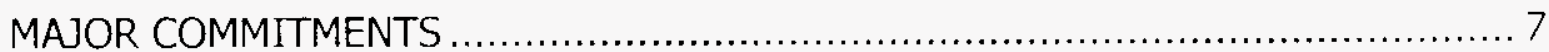

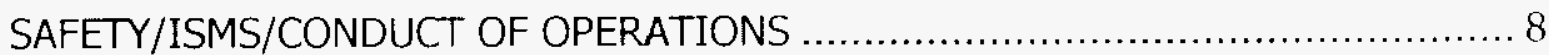

REGULATORY/EXTERNAL/DOE-RL \& HQ ISSUES AND REQUESTS ….............. 12

TOTAL COST/SCHEDULE OVERVIEW ..................................................... 13

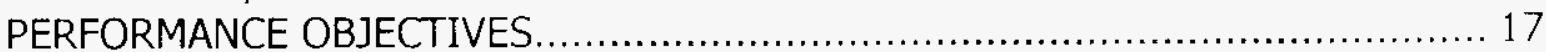

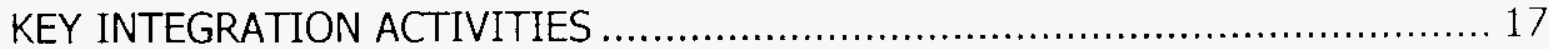

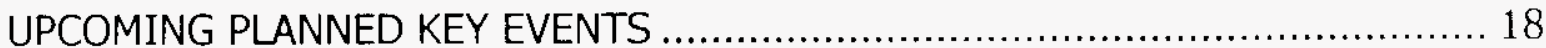

SECTION B - RESTORING THE RIVER CORRIDOR PROJECT SUMMARIES … 19

REMEDIAL ACTION AND WASTE DISPOSAL PROJECT …............................. 20

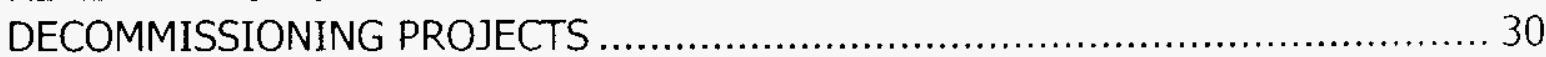

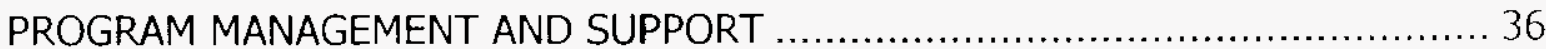

\section{SECTION C - TRANSITIONING THE CENTRAL PLATEAU PROJECT} SUMMARIES

GROUNDWATER/VADOSE ZONE INTEGRATION PROJECT ............................ 43

SURVEILLANCE/MAINTENANCE AND TRANSITION PROJECTS ........................ 54 


\section{ENVIRONMENTALL MANAGEMENT PERFORMANCE REPORT ENVIRONMENTAL RESTORATION \\ NOVEMBER 2000}

INTRODUCTION

The monthly Environmental Restoration (ER) Environmental Management Performance Report consists of three sections: Section A - Executive Summary, Section B - Restoring the River Corridor Project Summaries, and Section C - Transitioning the Central Plateau Project

Summaries. All cost, schedule, milestone commitments, performance measures, and safety data is current as of September 30 . Accomplishments, Issues and Integration items are current as of October 26, uriless otherwise noted. For this month's report, emphasis is focused on providing a fiscal year 2000 (FY00) summary overview of accomplishments, cost/schedule performance, and key integration activities.

Section A - Executive Summary. This section provides an executive level summary of Bechtel Hanford, Inc.'S (BHI) performance information from a FYOO perspective and is intended to bring to Management's attentior that information considered to be most noteworthy. The Executive Summary begins with a description of notable accomplishments that are considered to have made the greatest contribution toward safe, timely, and cost-effective cleanup during FY00. Major commitments are summarized that encompass Hanford Federal Facility Agreement and Consent Order (Tri-Party Agreement) milestones and FYOO Management Commitment milestones. Safety statistics are also included. Issues that require management and/or regulator attention and resolution status are addressed. Fiscal year-end ERC Project cost and schedule variance analysis is summarized. The Key Integration Activities section highlights site activities that cross contractor boundaries and demons:rates the shared value of working as a team to accomplish the work. The Executive Summa $y$ ends with a listing of major upcoming planned key events within a 90-day period.

Section B - Restoring the River Corridor. This section contains more detailed FYO0 activity information and performance status for the three projects within the 'Restoring the River Corridor' outcome. These three projects ccnsist of the Remedial Action and Waste Disposal (RAWD) Project, Decommissioning Projects, and the Program Management and Support (PM\&S) Project.

Section C - Transitioning the Central Plateau. This section contains more detailed FY00 activity information and performance status for the two projects within the 'Transitioning the Central Plateau' outcome. These two projects consist of the Groundwater/Vadose Zone (GW/VZ) Integration Project and the Surveillance/Maintenance and Transition (SM\&T) Projects.

Information in this report is identified with a green, yellow, or red text box used as an indicator of the overall status. Green indicates work or issue resolution is satisfactory and generally meets or exceeds requirements; yellow indicates that significant improvement is required; and red indicates unsatisfactory conditions requiring immediate corrective actions. 


\section{ENVIRONMENTAL MANAGEMENT PERFORMANCE REPORT ENVIRONMENTAL RESTORATION \\ NOVEMBER 2000}

\section{Section A: Executive Summary}




\section{ENVIRONMENTAL MANAGEMENT PERFORMANCE REPORT ENVIRONMENTAL RESTORATION \\ NOVEMBER 2000}

\section{SECTION A - EXECUTIVE SUMMARY}

Financial / Performance Measures data as of month-end September. All other data as of October 26, 2000 (unless otherwise noted).

\section{NOTABLE ACCOMPLISHMENTS:}

Significant progress was achieved in al' areas of Fivironmental Restoration (ER) Projed activities during fiscal year 2000 (FY00). All 16 FYOO planned Tri-Party Agreement milestones were completed, as well as all three fyou HQ mandagement commitment milestontes. In addition, one FYO1 Tri-Party Agreement milestone (M-24-46, RCRA 2-well installation) was completed 15 weeks ahead of sche'dule. Further, all Environmental Management (EM) corporate performance measures were exceeded in every category. On May 22, Fnvironmental Restoration Contractor (ERC) personnel reached one million hours worked without a lost workday injury. This was the fourth thine that ERC achieved this milestone since the Hanford Site contract was awarded in July 1994. Following are more notable FYOO ER Project accomplishments that have been grouped into three categories: momentum, progress, and completion/removal. ER Project's top ive accomplistiments for froO are underlined for casy recognition. Additional ER accomplishments are identified in the following individual project sections.

\section{RIVER CORRIDOR:}

Momentum: (how Hanford cleanup has been "sped up")

Remediation activities were initiated at two new locations within the 100 Area. 100 F Area remediation activities commenced or: lilly 10, wolve weeks ahead of schedule (satisfying TriParty Aqreemeni Milestone M-16-13412. 100 N Area remediation activities were also initiated on July 21 (satisfyirig Hanford Site Resourse Consenvation and Recovery ACt (RCRA) Permit requirements). The 100 Area Burial Ground Record of Decision. (ROD) received requlator approval on September 25. All waste sites in the 100 Area are now covered under a ROD which signifies cleanup criteria and requirements have been established for the nine reactor areas along the columbia River.

Demolition of the remaining ancillary siructures was completed for both $f$ and DR Reactors, cxcept for the F Reactor fuel storage b.3sin (FSB) and DR Reactor FSB stairwells. Demolition of the F Reactor FSB began on Septernter 25, and demolition of the DR Reactor stallwells began on October 20. F Reactor interim sale storage (ISS) is scheduled for completion in 2002 (onte year ahead of schedule') DR Reactor iSS is scherduled for completion in 2001 (four years athead of schedulel.

O and H Reactor presurveys, walko'owns, estimatess, and biological cleanup activities were completed, and all required $D$ and it Re'actors' engineering documents were issued for review prior to intiating ISS dermolition acturities in FYO1 (acic'leriated from 2004 [D Reactorl and 2006 [H Reactor]).

Nine technology deployments were conpleted (F YOU HQ performance measure identified four

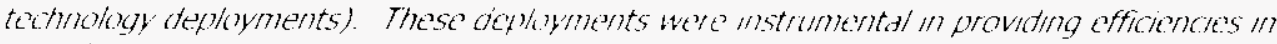
the efforts of waste' site' remediation. reactor 15S and Canvon Disposition Inithative (CDI) characteriation activitles.

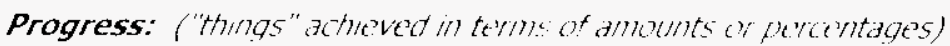

Over 59,000 metric tons $(639,000$ twis) of contaminded waste were removed in froo and itspresed in the Environmental Restoration Disposal facility (ERDF). To date, over 2.2 million

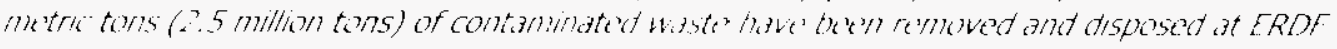




\section{ENVIRONMENTAL MANAGEMENT PERFORMANCE REPORT ENVIRONMENTAL RESTORATION \\ NOVEMBER 2000}

\section{NOTABLE ACCOMPLISHMENTS continued:}

since disposal operations began in July 1996. An average of 125 waste containers is transported to ERDF daily from Hanford remediation sites.

Excavation was completed for 42 contaminated waste sites (FYoO U.S. Department of Energy (DOE) Headquarters (HQ) performance measure identified 41 'vaste' sites). This brings the' total waste sites cleaned up to 219 of the 1,547 identified to date $(14 \%)$.

An average of 250 monthly entries was achieved (since February) into the 233-S Plutonum Concentration Facility with no lost workdays occurring. Confincd workspace environments and contamination hazards are encountered during each entry where decommissioning activities are being performed.

Loadout hood dismantlement and decontamination activities were completed in the 233-5 facility.

Dry cleanup and gross decontamination of the 233-5 process hood floor were completed. A total of 51 polyjars (0.5 liter in size) containing loose material was collected.

Removal and disposal (to ERDF) of 59 meters (193 feet) of $233-5$ exhaust and supply roof duct were completed. A new work approach that allowed removal of larger duct sections improved efficiency and lowered worker safety risks.

A total of 19 lines was removed from the $233-5$ viewing room south end pipe trench.

HQ approval was received for the completed FYoO Baseline Updatt and Reconciliation change proposal. The Integrated Priority List for the FYO2 budget submittal was also completed.

FYO1-FYO3 Detailed Work Plan (DWP) management review meetings were conducted with BHI, $D O E$ Richland Operations Office (RL), HQ, regulators, and stakeholders to reach agreencht on future workscope. The FYO1-FYO3 DWP was approved on September 26. The seven-volume document establishes the basis for FYO1 ER work execution.

The Froo Smiall Business socioeconomic contractual goals were exceeded in all categories. All small, small disadvantaged, and women-owned small business prime contract goals have betell met or excecded for the entire $5 / x$ years of BHI's prime contract. In addition, this past year BHI was recognized as having the best small business statistics in Bechtcl Systems and Infrastructure (parent company of BHI).

Completion/Removal: (what's done and what's gone)

Construction of ERDF Cells \#3 and \#4 was completed in December 1999 (satisfying Ir. Party Agrecment Milestone M-16-92B). The two new cells doubled the capacity of waste storagc at ERDF.

Remediation and backfill were completed for the contaminated liquid waste sites in the $100 \mathrm{~B}, \mathrm{C}$ Area on February 25, five weeks ahead of schedule. $100 \mathrm{~B} / \mathrm{C}$ Area renlediation, which began in 1996, was the first remediation work activity initiated by the ERC towards mecting a Th-Party Agrecment milestone (Tri-Party Agreement Milestone M-16-08B duc March 31). Only pipelinte' and burial ground remediation remains in the $100 \mathrm{~B} / \mathrm{C}$ Area.

The' B Reactor Museum Feasibility Assessment (Phase II) Project document was complkted (satisfying Tri-Party Agreement Milcstone M-93-05). Supplemental cost estumbates for hid.ial mitigation were also completed, and work was initiated. 


\section{ENVIRONMENTAL. MANAGEMENT PERFORMANCE REPORT ENVIRONMENTAL RESTORATION \\ NOVEMBER 2000}

\section{NOTABLE ACCOMPLISHMENTS continued:}

Project closerout ieports were completed for four faclities including the 10 s-F Biological Laboratory, 119-DR Exhaust Air Filter Simpling Bulding, 116-D and 116-DR exhaust stack

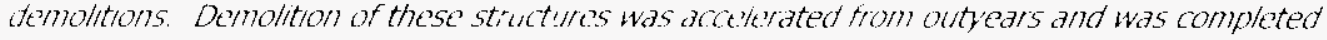
in Fyg9. Submittal of the closecut reports formally constitutes completion of facility denolition.

A major sustainef effort across all ERC projects and functional departments was focused on implementing, maintaining, and imploving our Integrated Environments Safety and Hoalth Management System (ISMS). Initial sfforts focusce on preparing for and supporting DOE verification of our ISMS and addressing opportunities for improvement. The Phase II verification audit which was conducte? by a DOE-led team, was siccesstully completed and resulted in no niajor findings.

Recognition was recenved from the Secretary of Energy with a Certificate of Appreciation for contributions to DOE's mission to pre' 'int pollution in operations, processes, and programs.

\section{CENTRAL PLATEAU:}

Momentum: (how Hanford cleanup has been "sped (up")

Utilizing a robotic crawler, the CDI dram header characterization was completed at U Plant (221-U Building) canyon facility in Aupust. The robot traveled the equivalent of nearly three football ficlds to visually inspect the ti l centimeter (24-inch) diameter drain line for structural integrity, to obtain radiation readings, and to collect samples of contaminated materials within the line. Obtaining access to the phamned 38 process cells was also completed.

Progress: ("things" achleved in terins of amounts or percentages)

Tectmical and management reviews of the System Assessment Capabillty (SAC) were completed resulting in validation of the approach being taken to develop the SAC and in the Groundwaterl vadose Zone Integration Project Expert Panel support for the SAC activity. The SAC Rev. 0 software development and testing were' also completed. Ihe SAC is being designed to provide. a cumulative assossment of the impat:; and risks associated with Hanford site contaminants.

flek actwitie's were completed at the Vadose Zone Transport Fick Study site in the 200 Area, and data interpretation also commenced. The main objectives of this field study are to evaluate the' underground tank leak issus, improve vadose monitoring capabilities, identify key transport processies, and provide' data' for model ventication.

FYou ISRM Prolut activities were cornuleted that included awarding the contract constructing an c'vaporation pond, installing 16 wells: and initiating chemical barricr injections and withdrawals in 10 wells (satisfying a Fy 00 HQ Mandagement Commitment Milestone). The subteranean chenical barrier is 31 meters (100 foct) deef and extends 198 meters ( 650 feet) botween the DR feactor aind the Cohmbia River. By 200 ? the barrier 15 expected to reach its fingl terngth of 70 ? meters $(2,300$ feet $)$.

Phase I was completed for the 618-1.1 Burial Ground clevated tritum investigation. The 618 11 Gurial Ground is located adjactnt to a commercial nuclear reactor complex and is about 6 klomiters ( 3.5 miles) from the Columtia River. Phase I imvolved sampling and analysis of 22 we'/s for tritum and other constituents. Re'sults mdicated two areas of high concentrations of hellum, which is a natural byproduct of the radioactive decay process of tritiun. Phase II of the' tritium inve'stigation will indude obtaining additional soll gas samples and two groundwater samples. The results of the additionis' tests will he'p determine if the helium is coming from a tritum surat bured in the waste site' ar from tritum cimtammation in the groundwater. 


\section{ENVIRONMENTAL MANAGEMENT PERFORMANCE REPORT ENVIRONMENTAL RESTORATION \\ NOVEMBER 2000}

NOTABLE ACCOMPLISHMENTS continued:

All five groundwater pump and treat systems operated atove the planned $90 \%$ avallability during FYOO (97\% actual; 90\% planned). The pump and treat systems remove contaminants (carbon tetrachloride, strontium, and chromiun:' from the groundwater and mitigate funther migration to the Columbia River. Approximately 1.1 billion liters of groundwater werc processed during FYO0; over 4.3 billion liters of groundwater have been processed to date.

Plutonium loadout hood stabilization activities were completed in the REDOX facility which is located in the 200 Area.

Surveillance and maintenance (S\&M) activities were initiated in the B Plant interior after Fluor Hanford (FH) completed required corrective actions to the building ventilation system. There was no evidence of any degradation due to the ventilation system beng inoperable for more. than ten months. No entry was allowed into the facility while the ventilation system was being repaired.

Completion/Removal: (what's done and what's gone)

Froo field characterization activities were completed for the 200-CW-1 Gable Mountain, B Pond Cooling Water Operable Unit. This included 12 test pits and one borehole. Significant cost savings resulted from utilizing prior-year lessons learned on this project.

Deactivation of the old $100 \mathrm{~N}$ Area water plant was completed, and construction and startup of the new replacement water plant was also achieved.

Legacy waste removal was completed at $K E, K W$, and H Reactors. 


\section{ENVIRONMENTAL. MANAGEMENT PERFORMANCE REPORT ENVIRONMENTAL RESTORATION \\ NOVEMBER 2000}

\section{MAJOR COMMITMENTS:}

\section{Tri-Party Agreement Milestorres.}

A total of 17 Tri-Party Agreement milostones were completed in FYoO. All 16 planned FyoO Thi party Agreement milestones were achieved as of August; 15 ahead of schedule, and one behnd schedule. In addition, one FYO1 Tri-Paty Agreentent Milestone M-24-46 (due Docember 31 ,

?000), was completed on September 17, 15 weeks ahtead of schedule.

Total Tri-Party Agreement Milestones Completed in FYOO

Total Fyoo Pianned/Completed 7hrough Septenter

Total Frol Completed (ahead of schedule) Through September

FYoO Management Commitment Milestones:

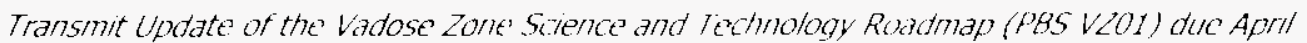
30.

Status: Complete. Draft was transmitted to RL on April 28.

Install Wells and Initiate Injection of the Barrier for Phase I of the In Situ Redox Groundwate" Remediation (PBS EROB) due September 30.

Status: Complete (two months ahead of schedule). The 16-well installation was completed on April 24. Bamer injection was mitiated on August 1.

Complete the Semi-Annual Groundwater Vadose Zone. Report (Dectmber 1999 - March 2000) (PBS VZO1) due May 31.

Status: Complete. Final document was transmitted to RL on May 31.

EM Corporate Performance Measures:

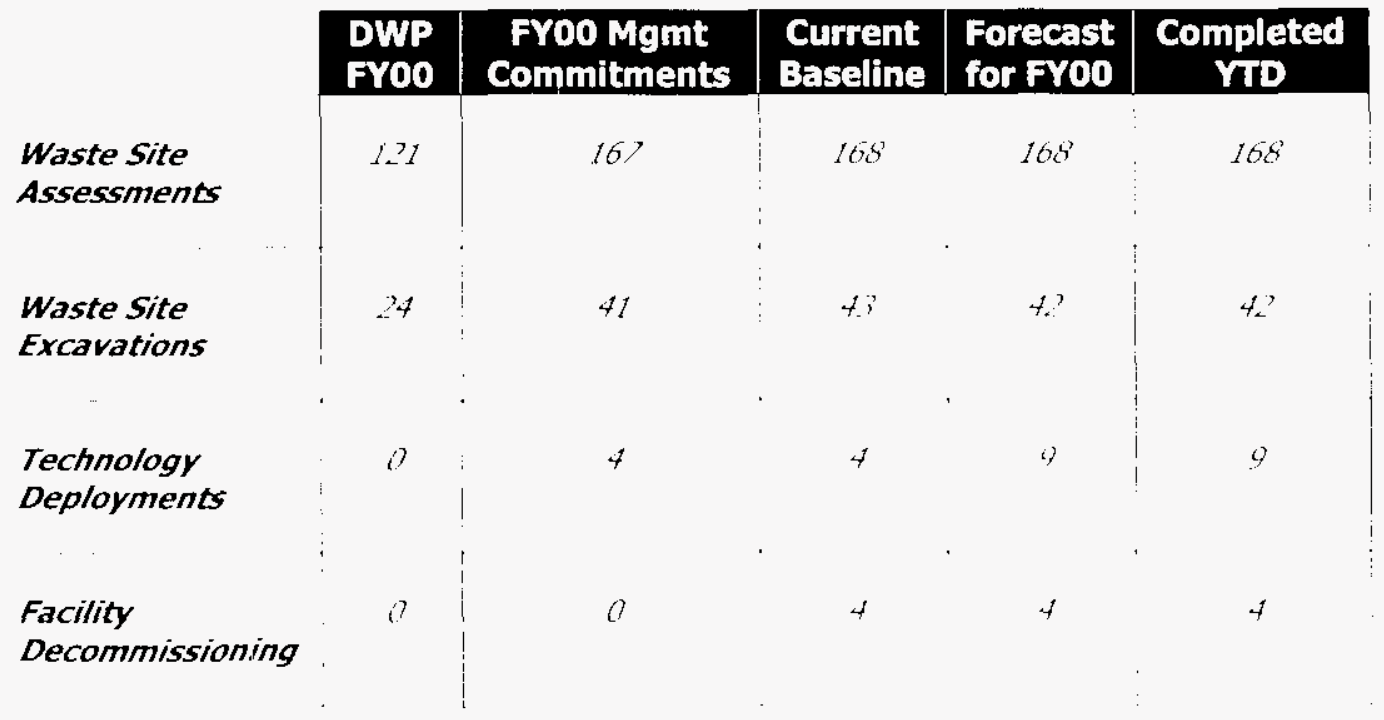




\section{ENVIRONMENTAL MANAGEMENT PERFORMANCE REPORT \\ ENVIRONMENTAL RESTORATION \\ NOVEMBER 2000}
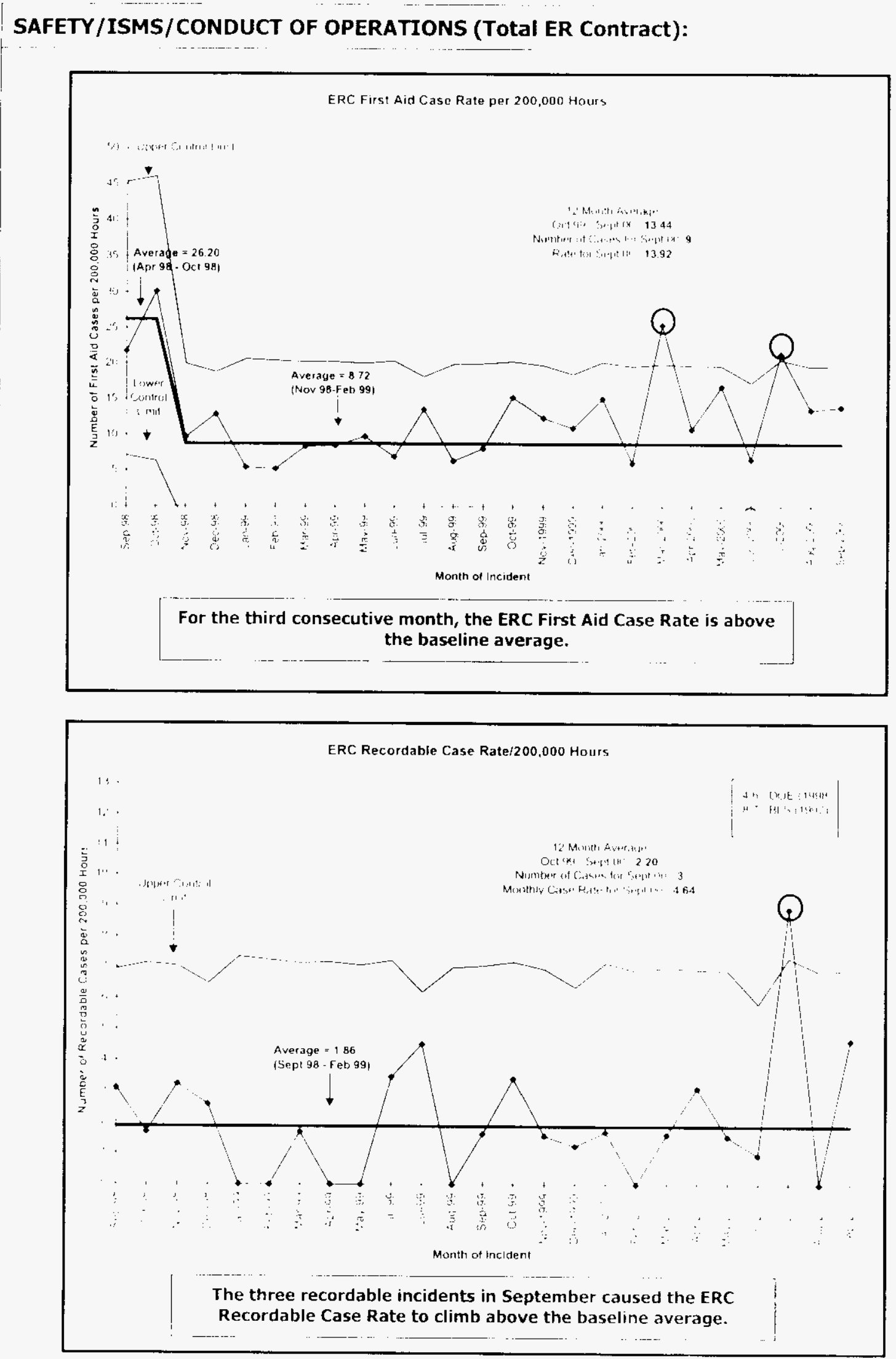


\section{ENVIRONMENTAL. MANAGEMENT PERFORMANCE REPORT ENVIRONMENTAL RESTORATION \\ NOVEMBER 2000}

SAFETY/ISMS/CONDUCT OF OPERATIONS (Total ER Contract) continued:

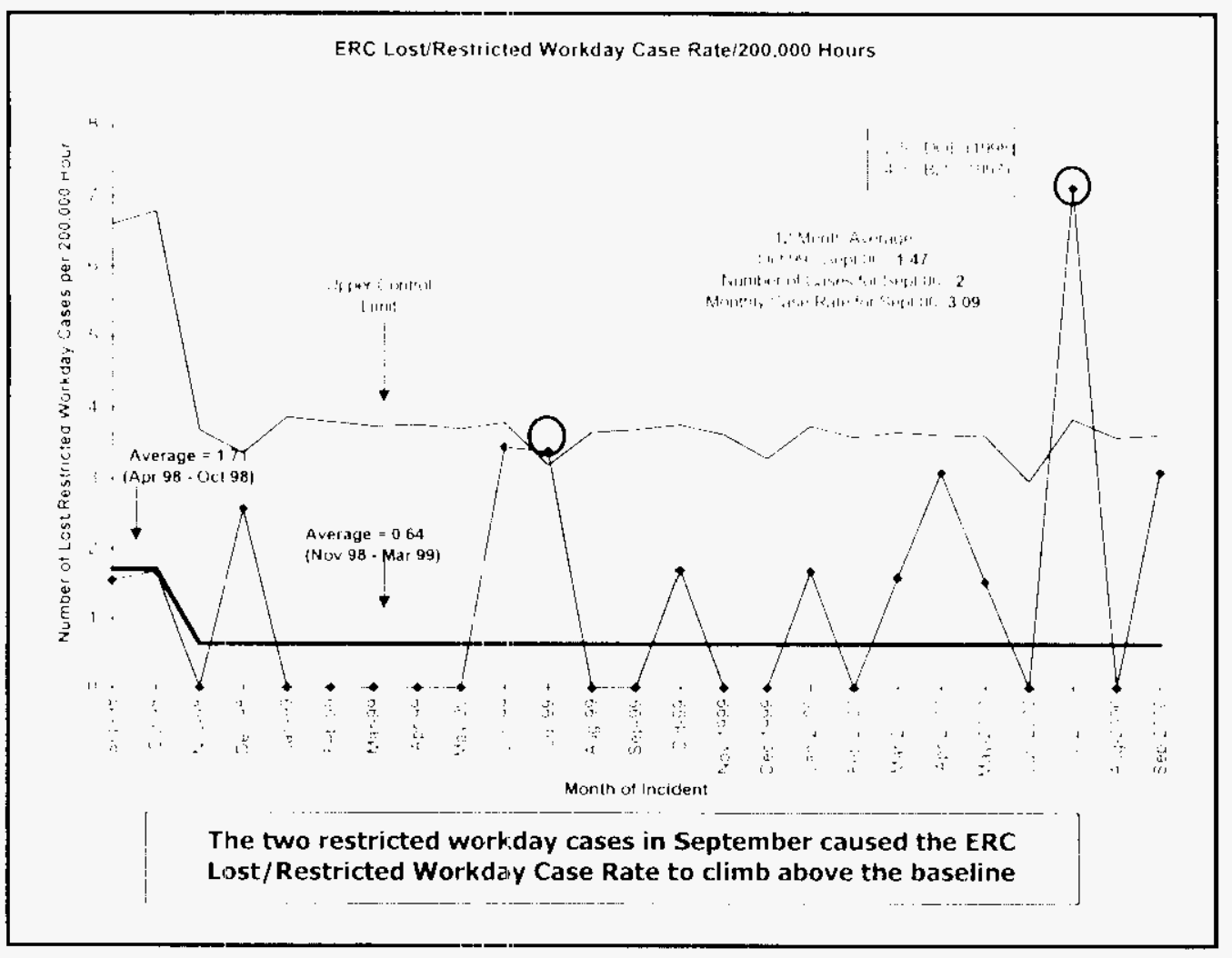




\section{ENVIRONMENTAL MANAGEMENT PERFORMANCE REPORT ENVIRONMENTAL RESTORATION \\ NOVEMBER 2000}

\section{SAFETY/ISMS/CONDUCT OF OPERATIONS (Total ER Contract) continued: \\ Safety:}

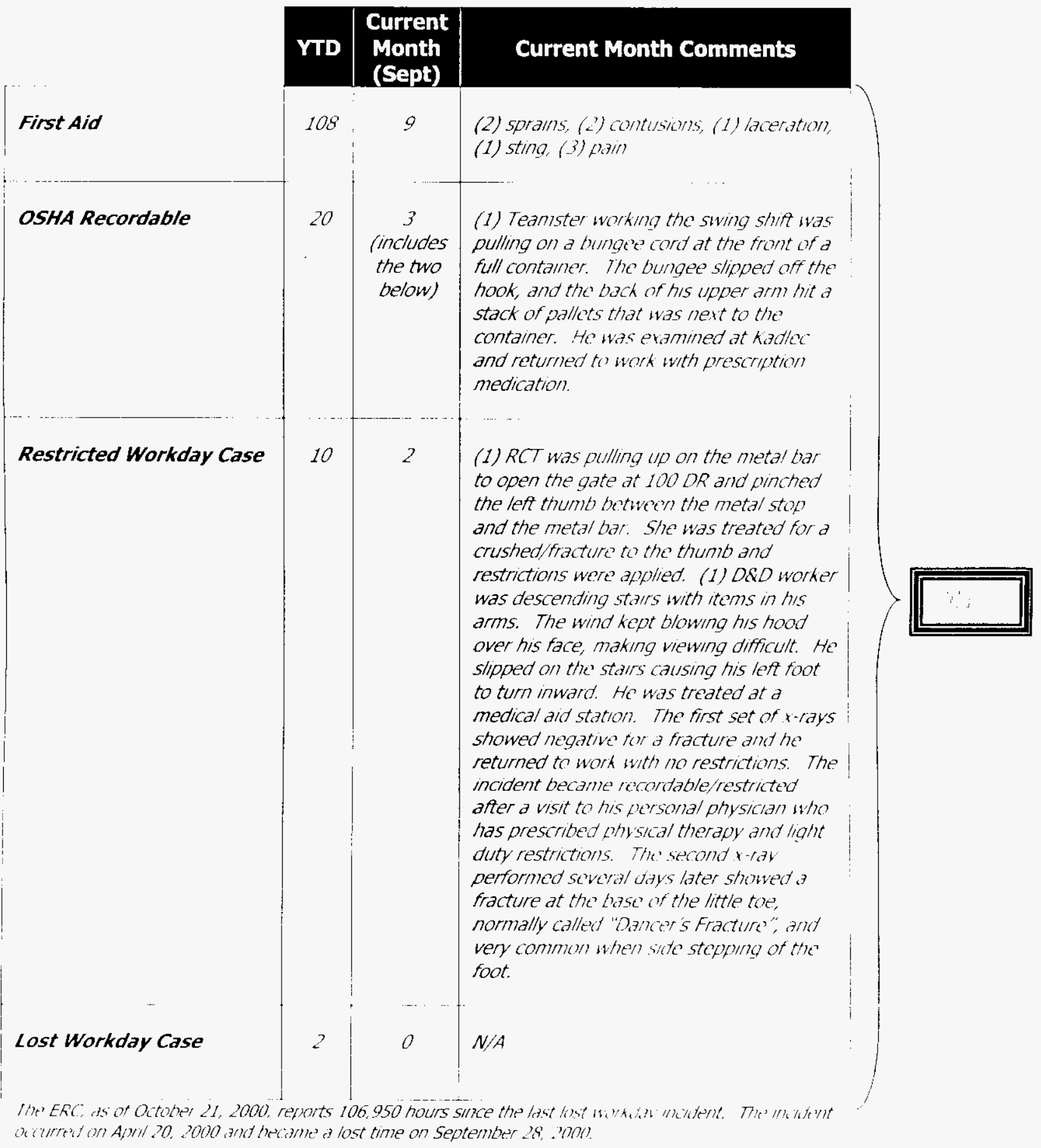




\section{ENVIRONMENTAL. MANAGEMENT PERFORMANCE REPORT ENVIRONMENTAL RESTORATION \\ NOVEMBER 2000}

\section{SAFETY/ISMS/CONDUCT OF OPERATIONS (Total ER Contract) continued: ISMS:}

DOE EM Performance Agreement: Develop and implement Integrated Safety Managcmicht (ISM) - Scptember 30, 2000

Status:"

- Completed all actions on the multi-discipline action plan for haadrds cvaluations.

- Contmuous improvement and employec awareness of ISMS is ongoing through the ISMS Question of thic Day Program.

- The. Detailed Work Plan (DWP) for FYos is approved. ISMS Program res,ponsibility has been transitioned to the QSEH Department Mandogr.

- Work is oncoung to establish safoty perfornance objectives, measures, and commitments for FYOt.

\section{Conduct of Ops:}

ERC-Corrective Action Tracking System (CATS) Trend Data 10/1/99 through 9/30/00

\begin{tabular}{|c|c|c|c|c|c|c|c|c|c|c|c|c|}
\hline & Oct-99 & Now- 99 & Dec: 99 & Jan-00 & Feb-00 & Mar -00 & Apt -00 & May-00 & Jun -00 & Jul-00 & Aug -00 & Seg-00 \\
\hline 1 nck \& Tag & 11 & 11 & $\therefore$ & $1:$ & $i:$ & 11 & $\because$ & $\because$ & $:$ & 1. & & 1 \\
\hline $\begin{array}{l}\text { Spills \{Reported on } \\
\text { Occurtence Reporls\} }\end{array}$ & 1: & $n$ & & !: & i! & $\therefore$ & 11 & $\therefore$ & . & 1 & 1 & 1. \\
\hline Procedure Violations & 1 & 2 & - & 3 & 1 & 1 & 2 & 2 & 1 & 0 & 0 & 0 \\
\hline \begin{tabular}{|l|} 
Inacequale lack or \\
Procedure \\
\end{tabular} & 1 & 1. & 2 & -1 & 3 & 2 & 0 & 2 & $\underline{0}$ & 4 & 2 & 1 \\
\hline Management Problems & 1 & 2 & 1 & 1 & 2 & 2 & 3 & 2 & 1 & 1 & 1 & 1 \\
\hline
\end{tabular}

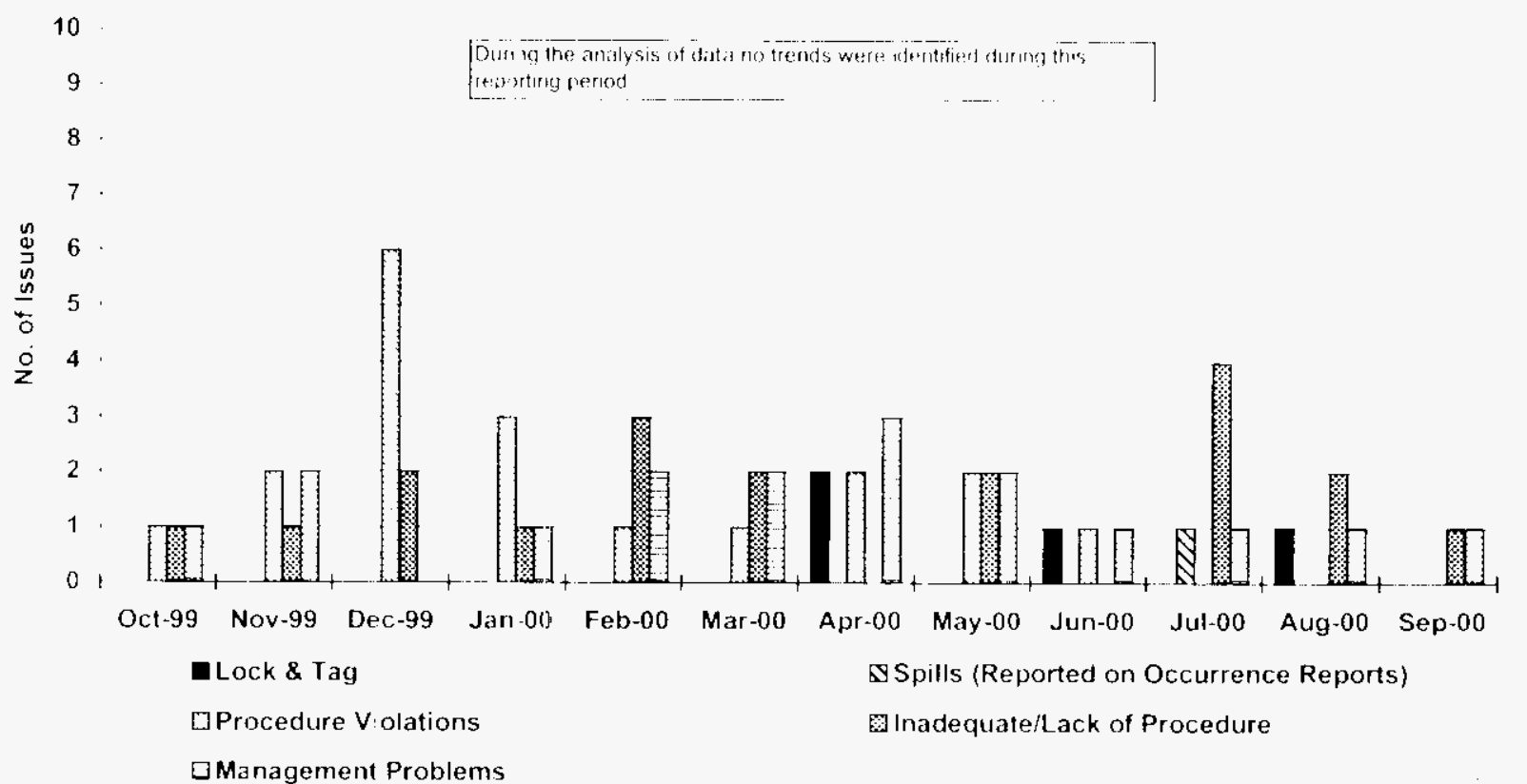

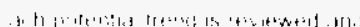

September Conduct of Ops Issues Continued on Next Page... 


\section{ENVIRONMENTAL MANAGEMENT PERFORMANCE REPORT ENVIRONMENTAL RESTORATION \\ NOVEMBER 2000}

\section{SAFETY/ISMS/CONDUCT OF OPERATIONS (Total ER Contract) continued:}

September Conduct of Ops Issues:

Procedure Problems:

Condition Description: Some documents are not identified as "All Quality Documtents as required by the BHI-EE-O2 Environmental Requirements Marlual". The types of records are the Effluent Record Sample Log (form BHI-TM-R127) and Effluent Sistem Checklist (BHI-TMR021). The RadCon supervisor stated that he was unaware of the se' requirements. The procedures (BHI-RC-04, Instruction 4.6 and BHI-RC-03, Procidurc ?.1) were reviewed to ensure compliance with the documentation requirements contalned within BHI-EE-O2 and found to not contain the documentation requirements for identifying on the records "Air Quality Document" nor do they reference the EE-02 manual to obtain thuse' requirements to prevent reoccurrence of this critical documentation requirements.

Corrective Action Plan: BHI-RC-04 Radiological Control Instructions Instruction 4.6 "Effluent Monitors Inspection and... "will be corrected to replace the "Air Quality Document" requirement and reference to BHI-EE-02. Thic procedure will also include steps for the RCT supervisor to ensure that the air qualitv documlentation is in order. This revision will be accomplished by 11/30/00. RadCon will mark all appropriate forms "Air Quality Document" beginning immediately. The "alarm bell" notation will be added to these requirements. This notation was added to RadCon procedures following the last revision of the subject procedure. The notation has prevented other problems similar to this deficiency from occurring to other procedures.

\footnotetext{
Management Problems:

Condition Description: On August 9, at approximately 10:45 a. m.. 1.30 gallons of sodum dithionite (an injection chemical used for reduction/oxidation procusses) was discharged to the ground. During routine operations, an operator was actuating valves called out by another operator. The operator actuating the valves misinterpreted a call to open the "GV" valve and instead opened the " $B V$ " valve, which resulted in the discharat. of the sodium dithionite. The quantity of chemical released to the ground was below icportable occurrence criteria. However, the operator error resulting in a valve misalignment led to a deviation from written procedures. Following a re-enactment of the event, the DOE Facility Representative suggested that the cvent be reported as a deviation from written procedures that resulted in adverse effects on performance of the ISRM proce's.s.
}

Corrective Action Plan: (1) Establish an Operations Engine? ring Group (reference ficld \$30, Lessons Learned) to provide onsite technical support and oversight. Taroct Completion Date: 09/05/2000, Completion Date: 09/05/2000. (?) Install a chech valve between the system and the chemical truck to privent iverflow. Target Completion Date: 10/01/2000, Completion Date: 10101:2000. (i) Fnginetring staff discuss the valve positions with operators, providing directions th the' optrators 11 how to check valves to see if they are open or closed. Taract Completion Date. 09/03/2000, Completion Date: 09/05/2000.

REGULATORY/EXTERNAL/DOE-RL \& HQ ISSUES AND REQUESTS:

Refer to individual Projed issues in the following Section $B$ and siction $C$ 


\section{ENVIRONMENTAL. MANAGEMENT PERFORMANCE REPORT ENVIRONMENTAL RESTORATION NOVEMBER 2000}

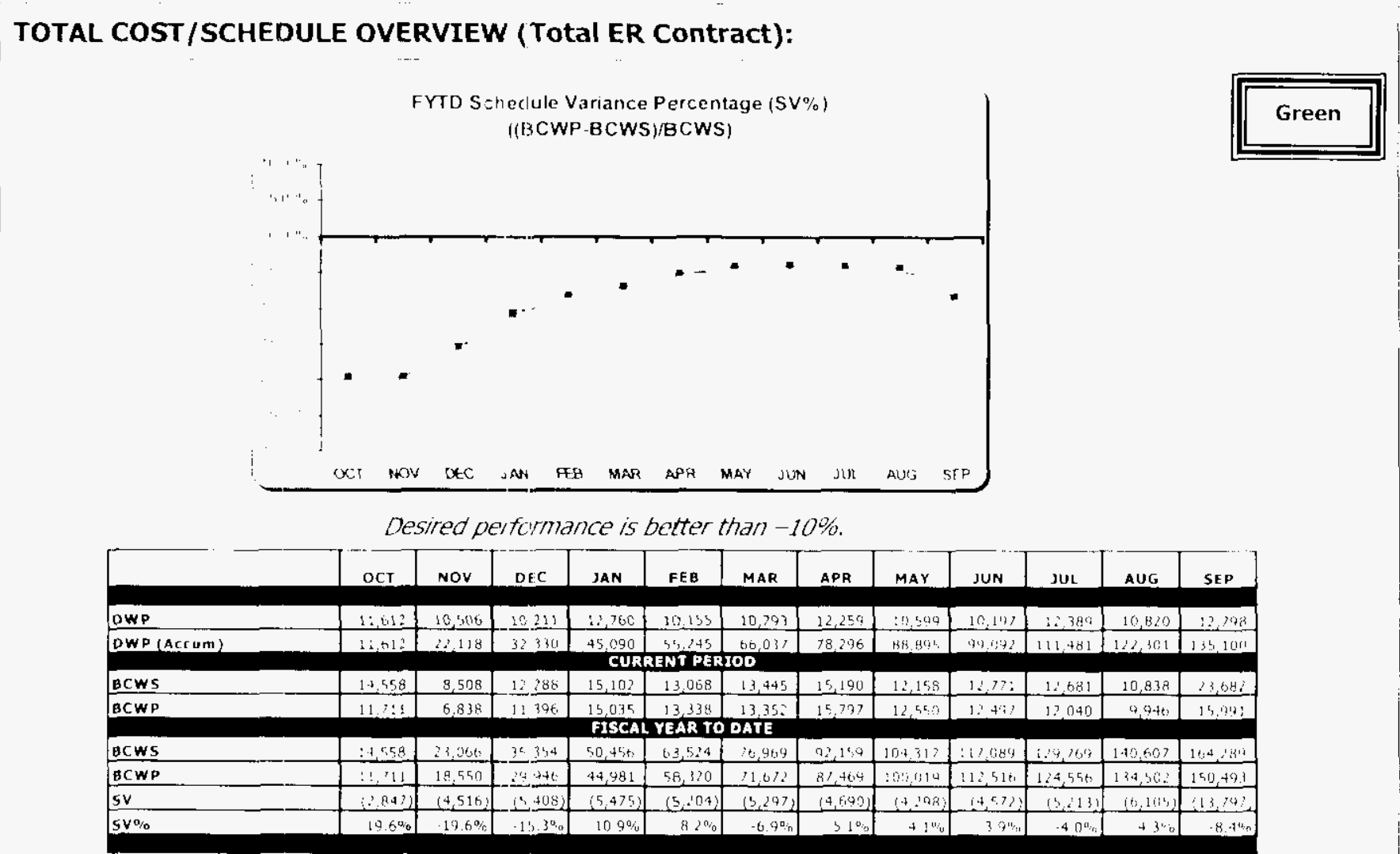

Fir variance explanation by PBS, see Project Status Section of each project.

FYTD Cost Performance Index (CPI) (ACWP/BCWP)

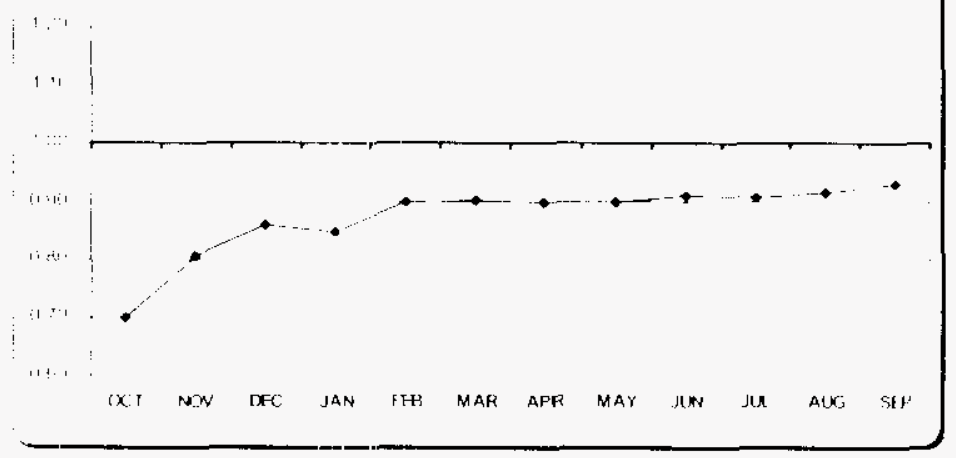

Desired Derformance is 1.0 or less.

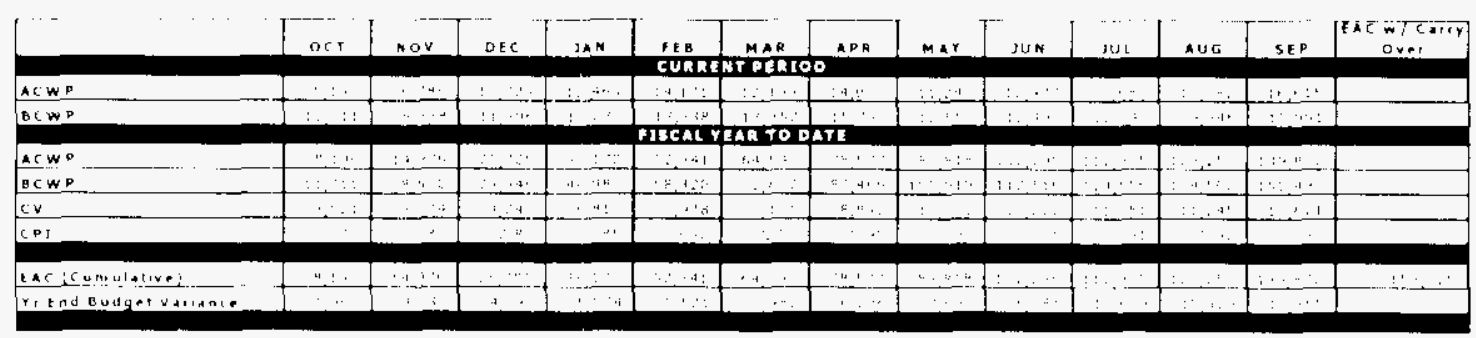

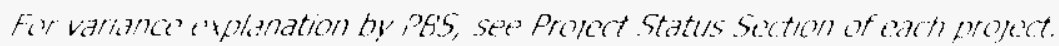




\section{ENVIRONMENTAL MANAGEMENT PERFORMANCE REPORT ENVIRONMENTAL RESTORATION \\ NOVEMBER 2000}

TOTAL COST/SCHEDULE OVERVIEW (Total ER Contract) continued:

\section{FY 2000 PERFORMANCE \\ FYTD SEPTEMBER 2000}

(\$K)

\begin{tabular}{|c|c|c|c|c|c|c|c|c|c|c|c|}
\hline & \multirow{2}{*}{$\begin{array}{l}\text { Dup } \\
\text { Eans }\end{array}$} & \multirow{2}{*}{$\begin{array}{l}\text { CFinT } \\
\text { Eans }\end{array}$} & \multicolumn{3}{|c|}{ FYID } & \multicolumn{2}{|c|}{$\begin{array}{c}\text { YID } \\
\text { SaEneVaraxa }\end{array}$} & \multicolumn{3}{|c|}{$\begin{array}{c}\text { YT } \\
\text { costripatace }\end{array}$} & \multirow{2}{*}{$\begin{array}{l}\text { moD } \\
\operatorname{EAC}\end{array}$} \\
\hline & & & EOWS & ECW & ACNP & $\$$ & $\%$ & 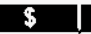 & \begin{tabular}{l|l}
$\%$ & -1
\end{tabular} & का & \\
\hline ERO1 100 NeaFzA & (1) 34 & $30 x$ & 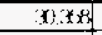 & 28.628 & 23751 & $1.6 \pi$ & $\therefore+$ & $+463:$ & $1 \%$ & (1) 只) & $\therefore, 460$ \\
\hline 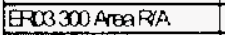 & 3150 & $6,6 \pi$ & $66 \pi_{3}$ & 5291 & 4,794 & wt & 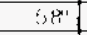 & $1.4 \div !$ & $238 x^{2}-1$ & $0 \pi_{1}$ & 52187 \\
\hline EO4 G W Waste Osposal & 15,146 & 20.566 & Z) $(x+1$ & X0.197. & 18.384 & $x+4$ & $1 \%$ & $1.8 \pi$ & 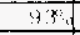 & 091 & 18,02 \\
\hline Parethote & 46,667 & 5,509 & 5,579 & 55.170 & 4680 & $-2,419$ & $42 \%$ & 8.301 & $150 \%$ & 0.85 & 49,347 \\
\hline GRD ZDOANEARA & 35342 & $3.5 \mathrm{~d}$ & $3+6 \times 2$ & 2497 & 2456 & -9 & $\therefore$ & 1611 & $58 d$ & $0 \pi$ & 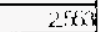 \\
\hline EOB QNMGrogemert & $19,3 \times 4$ & $2 \pi n$ & $2.7 n \pi$ & $21,3 * 4$ & 21.0693 & $-4.12 \times 1$ & $1 \because 1$ & $2 \%$ & 134 & 0,4 & $2 x: x+2$ \\
\hline VOr OWV & 11,325 & $11.2 \mathrm{~m}$ & $11,2 \mathrm{~N}$ & 10.390 & 10,170 & 911 & 814 & 180 & $1 x^{*}$ & $0(3)$ & $11.64+2$ \\
\hline anzastotat & 34,253 & 40,6389 & 40,638 & 35,191 & $33 \times 9$ & $-5,447$ & $-13,4 \%$ क & 1.498 & $43 \%$ & 096 & 39.185 \\
\hline EROSDED & $8.4 \times \sqrt{x}$ & $17.12 x$ & $1 / .12 x$ & 15.420 & 152376 & $-1, \pi \times 1$ & $-16(\%)$ & 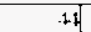 & (a) $x_{1}$ & $i(0)$ & 17.191 \\
\hline Dostated & 8,446 & 17,220 & 17,129 & 15,000 & 15,376 & $-1,709$ & $-10.0 \%$ & 44 & $0.3 \%$ & 1.00 & 17,141 \\
\hline ERO5SM & $12 \times 91$ & $14.5 \times 1$ & 14.500 & 13.329 & $13,0 \mathrm{ax}$ & 1.192 & $8 \%$ & Ant & 181 & 0033 & 14.37 \\
\hline Goflong Temsin & 47 & +4 & 40 & 46 & 39 & 0 & 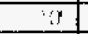 & 7 & $1 \leqslant 2,0$ & 094 & 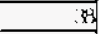 \\
\hline Susctatd & 12,338 & 14,566 & 14576 & 13,384 & 13,132 & -1.192 & $-82 \%$ & 252 & $1.9 \%$ & 0.96 & 14,410 \\
\hline ER10 GRCPMS & 27.000 & 28.522 & 29.5242 & 25.775 & 26.248 & $1.74 \pi$ & if 13 & $2 \times 1$ & 20 & $0\left(t_{1}\right.$ & 28,001 \\
\hline ER10R FMBS & 5,800 & 5806 & 5.836 & 4.563 & 4.553 & $-1,890$ & 2209 & at & $0 \phi_{1}$ & 100 & $2,8 \times 6$ \\
\hline Amsond & 33,397 & $34,35 \mathrm{~F}$ & 34,35 & 31,328 & 30,601 & -3009 & $\mathrm{AB} /$ & इ्ञा & $1.7 \%$ & 0.96 & 33.840 \\
\hline GRANTOTAL & 135,101 & 164,289 & 164,289 & 150,493 & 139,871 & $-13,706$ & $84 \%$ & 10,622 & $7.1 \%$ & 0.93 & 153,925 \\
\hline
\end{tabular}

${ }^{*} C P I=A C W P / B C W P$

\section{Cost/Schedule Status:}

\section{Cost Variance Summary}

At FYOO end, the ER Project had performed $\$ 150.5 \mathrm{M}$ worth of work, at a cost of $\$ 139.9 \mathrm{M}$. This results in a favorable cost variance of $\$ 10.6 \mathrm{M}(+7.1 \%)$. The positive cost variance is attributed to ERDF cover design and construction/transportation underruns, utilization of more efficient asbestos abatement methods (asbestos and piping removedidisposed concurrently), savings in soil sampling and analyses by using local laboratory and onsite resources, F Area remediation savings in site preparation and reallocating resources between the F and Hi Areas, savings in Landfill 1 A $1 B$ remediation (such as working two sites concurrently), efficiencles learned in prior work applied to Gable Mountain and B Pond test pit trenching, feuver resources utiliated than planned for GW VZ Science and Technology (S\&T) and Characteriation of Systems, significantly lower F and DR Reactor ISS sample analysis costs than planned due to utilizing larger data groups (economies of scale), underruns on B Plant SisM and Radiation Area Remedial Action (RARA) stabilization. Underruns were utilized to perform other ER work.

\section{Schedule Variance Summary}

The ER Project ended FYOO $\$ 13.8 \mathrm{M}(-8.4 \%)$ behind schedule. (Efficiencies allowed for approvalimitiation of approximately $\$ 5.0 \mathrm{M}$ multi-year superstrctch and other remediation in FYOO with most of the work planned for Fyot (planned schedule variance/carryover). After adiustment for this work, the net negative schedule variance would bo $\$ \$ .8 M(5.59)]$. The negatwe. schedule variance is attributed to remediation backfill de'/ay's pending resoluthon of differing chromium sample laboratory results, 100 DR south pipeline confirmation sampling bethind schedule due to design preparation delays, 300 Area contract awart for drum removal deferred due to bidder request, GW/VZ Characterization of Systenis delayed due to k'sourc'

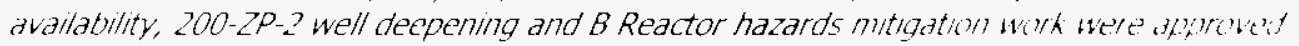

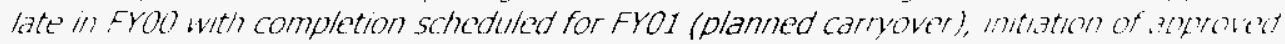

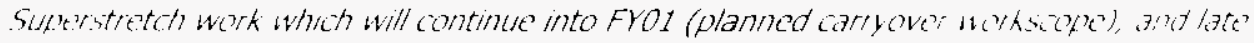
billings for Rl site wide assessments. 


\section{ENVIRONMENTAI. MANAGEMENT PERFORMANCE REPORT ENVIRONMENTAL RESTORATION \\ NOVEMBER 2000}

TOTAL COST/SCHEDULE OVERVIEW (Total ER Contract) continued:

FY2000 Funds Management

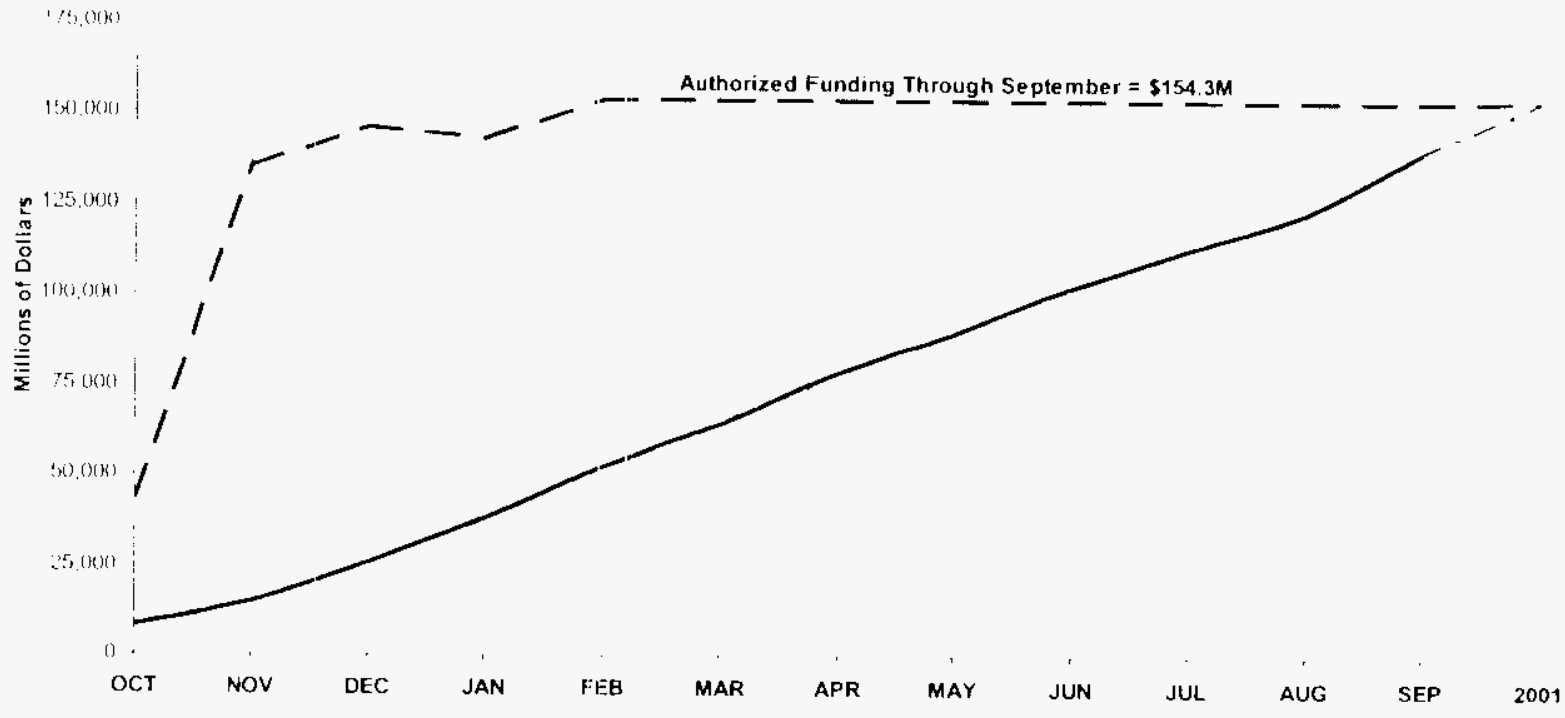

\begin{tabular}{|c|c|c|c|c|}
\hline PAS & PaS Title & Authorized Funds & ACWP & Funding Carryover \\
\hline RL-ER01 & 100 Area Remediation & $\$ 25,969,999$ & $\$ 23,751,023$ & $\$ 2,218,976$ \\
\hline RL-ELO2 & 200 Area Remediation & $\$ 3,130,000$ & $\$ 2,456,402$ & $\$ 673,598$ \\
\hline RL-ER03 & 300 Area Remediation & $\$ 5,827,400$ & $\$ 4,800,187$ & $\$ 1,027,214$ \\
\hline RL-ER04 & Waste Disposal Facility & $\$ 19,339,999$ & $\$ 18,324,084$ & $\$ 1,015,915$ \\
\hline RL-ER05 & S\&M - Facility Transitioning & $\$ 14,335,000$ & $\$ 13,092,640$ & $\$ 1,242,360$ \\
\hline RL-ER06 & Decommissioning Project & $\$ 17,150,000$ & $\$ 15,375,877$ & $\$ 1,774,123$ \\
\hline RL-ER07 & Post Closure - 5\&M & $\$ 60,900$ & $\$ 38,588$ & $\$ 22,312$ \\
\hline RL-ER08 & Groundwater Management & $\$ 13,795,730$ & $\$ 11,140,120$ & $\$ 2,655,610$ \\
\hline RL-ER08 & Gro undwater Management LI & $\$ 778,868$ & $\$ 654,377$ & $\$ 124,491$ \\
\hline RL.ER09 & N. Basin Cleanup & $\$ 3,173$ & $\$ 349$ & $\$ 2,824$ \\
\hline RL-ER10 & Program Management \& Sugport & $\$ 26,989,858$ & $\$ 26,247,800$ & $\$ 742,058$ \\
\hline RL-VZ01 & GW'Vadose Zone Integration Project & $\$ 6,370,000$ & $\$ 5,407,853$ & $\$ 962,147$ \\
\hline S/Total BHI & & $\$ 133,750,927$ & $\$ 121,289,299$ & $\$ 12,461,628$ \\
\hline$R L-V Z 01$ & GW ${ }^{\prime}$ Vadose Zone (PNNL) & $\$ 4,585,334$ & $\$ 4,574,200$ & $\$ 11,134$ \\
\hline RL-ER03 & 300 Area Remediation (PNNL) & $\$ 0$ & $\$ 0$ & 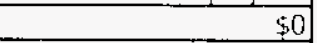 \\
\hline RL.ER08 & Groundwater Monitoring (PNNL) & $\$ 9,693,363$ & $\$ 9,270,485$ & $\$ 422,878$ \\
\hline S/Total PNNL & & $\$ 14,278,697$ & $\$ 13,844,685$ & $\$ 434,012$ \\
\hline RL-ER03 & 300 Area Remediation (USFWL) & $\$ 6,546$ & $\$ 6,546$ & \\
\hline RL-ER08 & Groundwater Mgmt (RL) & $\$ 6,595$ & $\$ 6,595$ & $\$ 0$ \\
\hline RL-ER 10 & Program Management \& 5 upport (RL) & $\$ 5,834,838$ & $\$ 4,553,340$ & $\$ 1,281,498$ \\
\hline RL-VZ01 & Gwi Vadose Zone (RL) & $\$ 407,586$ & $\$ 196,713$ & $\$, 210,873$ \\
\hline S/Total RL & & $\$ 6,229,283$ & $\$ 4,736,912$ & $\$ 1,492,371$ \\
\hline Total ER & & $\$ 154,258,907$ & $\$ 139,870,896$ & $\$ 14,388,011$ \\
\hline
\end{tabular}




\section{ENVIRONMENTAL MANAGEMENT PERFORMANCE REPORT ENVIRONMENTAL RESTORATION \\ NOVEMBER 2000}

TOTAL COST/SCHEDULE OVERVIEW (Total ER Contract) continued:

\section{FY2000 Schedule Carryover}

\begin{tabular}{|c|c|}
\hline Bechtel Hanford, Inc. (\$000's) & 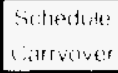 \\
\hline 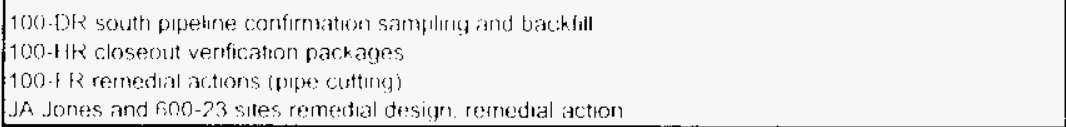 & $\begin{array}{rl}311: 8 \\
601 & 9 \\
10: 3 & 4 \\
1.2 & 430\end{array}$ \\
\hline S/T 100 Area Remedial Action (ER01) & 1.717 .8 \\
\hline $\begin{array}{l}618-4 \text { bural ground procurement package } \\
300 \text { - }+2 \text {. ROC support }\end{array}$ & $\begin{array}{l}3+3,3(i) \\
301\end{array}$ \\
\hline ST 300 Area Remedial Action (ER03) & 393.1 \\
\hline $\begin{array}{l}\text { E:R[YF transportation \& waste disposal for JA Jones and 600-23 sites isuperstritis: } \\
\text { ERDF vegetation for the intenm cover }\end{array}$ & $\begin{array}{r}3.1 \div 1 \\
180 \\
\end{array}$ \\
\hline \begin{tabular}{|ll} 
& $S T$ ERDF (ER04) \\
\end{tabular} & 363.1 \\
\hline 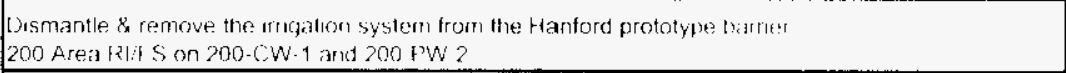 & $\begin{array}{l}7+3: 3 \\
201\end{array}$ \\
\hline \begin{tabular}{|l|l|} 
& ST 200 Area Characterization (ER02) \\
\end{tabular} & 96.4 \\
\hline $\begin{array}{l}200 \cdot Z P^{2}-1 \text { platform : valve upgrade? } \\
200-Z P^{2}-2 \text { FIT } \text { well deepening } \\
\text { RCRA well installation } \\
\text { Well decommussioning (superstretch) } \\
\text { Well maintenance. tritium sample collection }\end{array}$ & $\begin{array}{r}578 \\
368 \% \\
1.6318 \\
1.3102 \\
4339\end{array}$ \\
\hline S/T Groundwater Management (ERO8) & 3.702 .5 \\
\hline $\begin{array}{l}\text { F'eer revew (incl expert panel medma \#8, } \\
\text { Characterization of systems } \\
\text { System assessment capabilty (SAC, revision 1) }\end{array}$ & 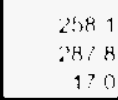 \\
\hline$S / T$ Groundwater Vadose Integration (VZ01) & 562.9 \\
\hline 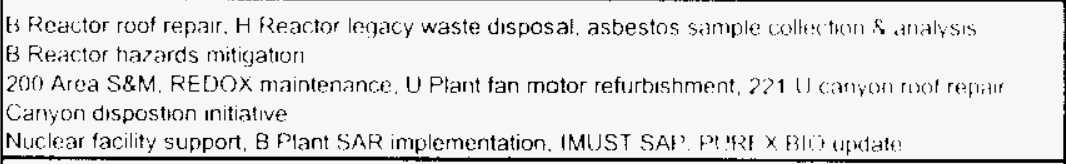 & $\begin{array}{rr}73 & 9 \\
i+3 & 8 \\
46 & 1 \\
116 & 7 \\
104 & 0 \\
\end{array}$ \\
\hline $\begin{array}{|cc|} & S / T S / M \& T(E R O S) \\
\end{array}$ & $1,229.5$ \\
\hline 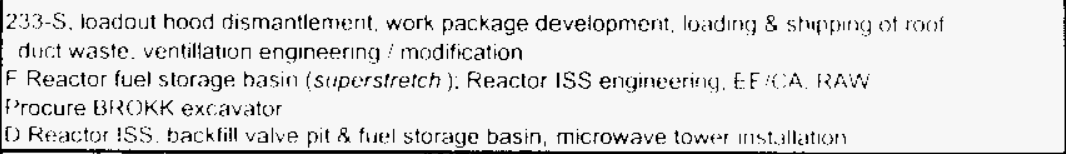 & 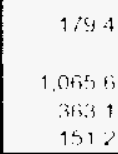 \\
\hline S/T Decommissioning Projects (ER05) & $1,759.3$ \\
\hline 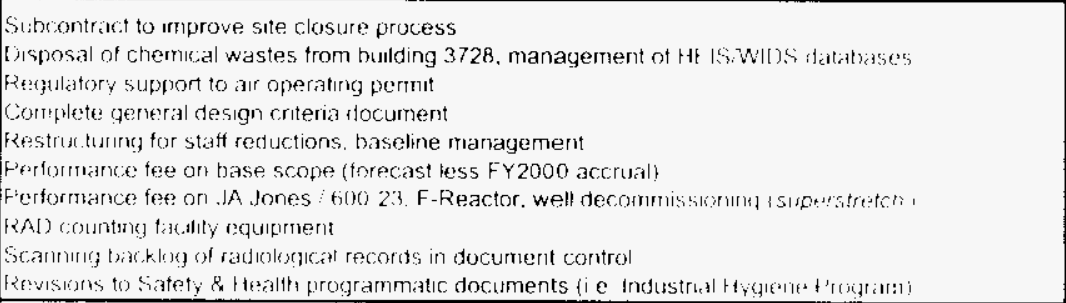 & 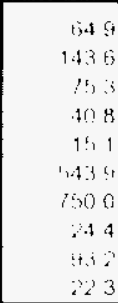 \\
\hline S/T BHI Program Management \& Support (ER 10) & 1.773 .5 \\
\hline Total Bechtel Hanford, Inc. & 11.598 .1 \\
\hline 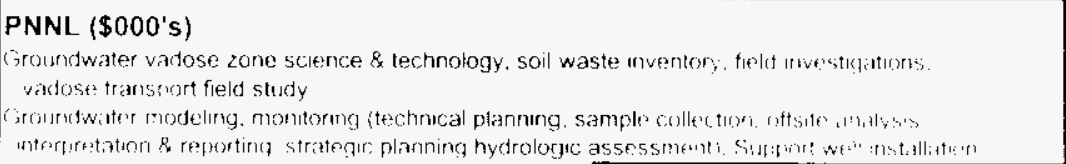 & $\begin{array}{l}2 / 47 \\
18+4: 1\end{array}$ \\
\hline Total PNNL & $1,063.2$ \\
\hline $\begin{array}{l}\text { DOE-RL - ER10 (\$000's) } \\
\text { 'rextran m. }\end{array}$ & 1. itip: \\
\hline Total DOE-RL & $1,368.2$ \\
\hline Total (BHI, PNNL, DOE-RL) & 14.029 .4 \\
\hline
\end{tabular}




\section{ENVIRONMENTAL. MANAGEMENT PERFORMANCE REPORT ENVIRONMENTAL RESTORATION \\ NOVEMBER 2000}

\section{PERFORMANCE OBJECTIVES:}

see following individual Project sections:

\section{KEY INTEGRATION ACTIVITIES:}

Following is a summary of significalit criss-culting intogration activities accomplished during FYOO. Refer to additional individuai frowect key integration activitic's noted in the following Section $B$ and Section $C$.

\section{Cross-Cutting:}

RL WBS/PBS Restructuring: BHI teamed with site contractors to support DOE-RL in development of a "Schedule Options Study" and provided support to DOE-RL in the restructuring of the Hanford Site Work Breakdown Structure. BHI Supported both the River Corridor and Central Plateau baseline teams. BHI supported development of the Budget Update Guidance (BUG) Phase II, which! includes details developing this baseline update basco on the revised PBS $W B S$, formatted to address the site outcomes.

300 Area Acceleration: BHI suppoited FH in the development of an accelerated closure plan. BHI provided the technical volumos for D\&D and Remedial Action. These technical volumes included scope, schedule, wost, and the methodology of ustimating. BHI assisted in the final write-up of the FH deliverable io RL. FH delivered the final product to DOE RL and prescnted the final product to the Site Management Board on July 17. Positive comments about the product were made and verbial recognition was given to the FH, BHI and PNNL integrated team.

DOE and Bechtel Staff Recognized for Pollution Prevention Efforts: In late July, U.S. Secretary of Energy Bill Richardson reccgnized several Department of Energy and Bechtel Hanford, Inc: eniployees for their waste minmization and pollution prevention accomplishments at Hanford. The LOE recognition acknowledged BHI's waste minnmization and pollution prevention activities over the last several years. Recent accomplishments at Hanford included reducing the amount of waste by more than 300,000 tons and avoiding costs of nearly $\$ 50 \mathrm{M}$ in 1999. BHI successtuily implemented the largest source reduction project in the DOE complex in 1999 . It involvec' cxtensive characterization of 417 waste sites. As a result, 129 sites were reckassified, enabing BHI to reduce the amount of low level radioactive. waste requirmg treatment by nearly 65,000 cubic yards and avording costs of more then $\$ 36 \mathrm{M}$. This single effort reduced more waste than all of the combined source reduction projects implemented throughout the DOE complex in 1998. Source reduction projects reduce pollution or waste generatid at this source. The use of new technology and value engineering assessments was cited as a reason for effectiveness of site characterization efforts, which resulted in substcintial cost savings w' the U.S. government and taxpayers. The DOF recognition a/so acknowledged BHIs too percent compliance with efforts "affirmative. procurement" requircme'nts, which direct the purchase of supplies and products mate from recovered or recteded materials.

Excavation at Wanapum Cache Site: The Wanapum tribe requested ER support for trenching to uncover the remains of timiee Wanapum cellars used to store fistumg gear, camif items, and preserved foods relating to a traditional fishing village last occupled in 19.4 . Th. Th" area being excavated is on the terrace of the Columbia River southeast of the 100 -H Arca. Fxazvations were. conducted in shailow lifts of approximately $10 \mathrm{~cm}$ to prevent damaging miaterials of interest to the fullest extemi possible. Materials of interest are defined as "Obyects of Cultural Patrimuny" unter the proviswons of the Native. American Giaves Protection and Repartriation Act 


\section{ENVIRONMENTAL MANAGEMENT PERFORMANCE REPORT ENVIRONMENTAL RESTORATION NOVEMBER 2000}

\section{UPCOMING PLANNED KEY EVENTS:}

Tri-Party Agreement Milestone M-13-25, Submit Uranium Rich Process Waste Group (a)o-Plv-

2) Work Plan, due $12 / 31 / 00$.

Tri-Party Agreement Milestone M-13-00K, Subnit 1200 NPL RI FS (RFI/CMS) Work Plan, dule $12 / 31 / 00$.

Tri-Party Agreement Milestone M-16-27A, Complete 100-HR-3 Phase I, ISRM Barrier Emplacement, due 12/31/00.

Tri-Party Agreement Milestone M-24-47, Install 4 Additional Wells at S5T WMA T, due $12 / 31 / 00$.

Tri-Party Agreement Milestone M-24-48, Install 4 Additional Wells at SST WMA TX-TY, du $12 / 31 / 00$.

Tri-Party Agreement Milestone M-24-00L, Install RCRA Groundwater Monitoring Wells Up to 50 in CY 2000, due 12/31/00. 


\section{Richland Operations Office \\ Environmental Restoration \\ Environmental Management Performance Report}

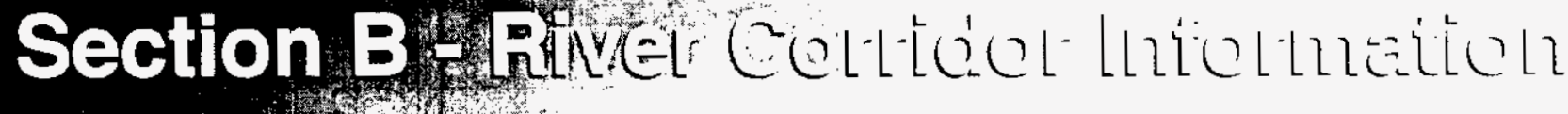

November 2000

- Remedial Action and Waste Disposal Project
- Decommissioning Projects

(Interim Safe

Storage and 233-S)
- Program Management and Support

\section{$-1$}
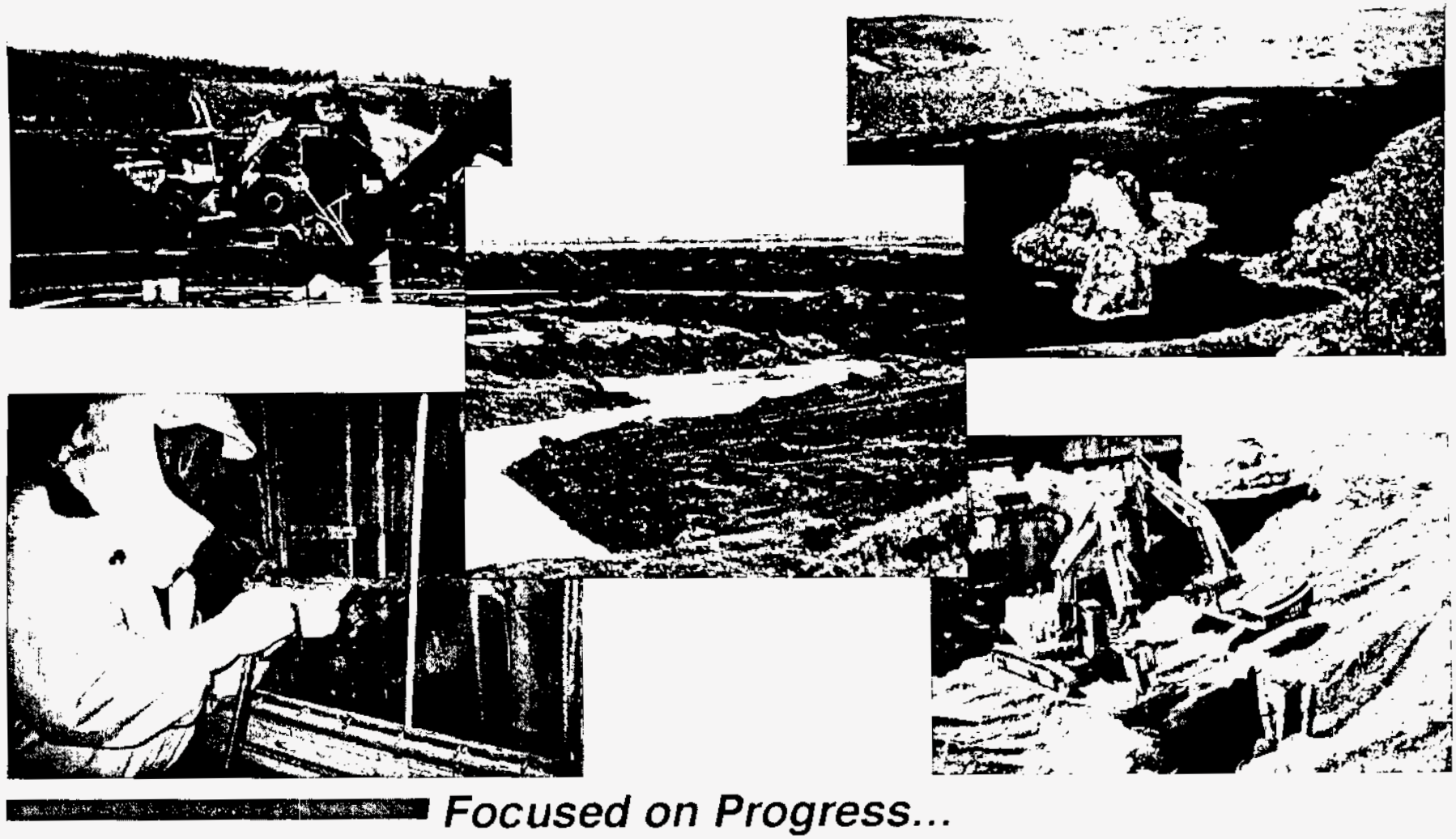

is. 


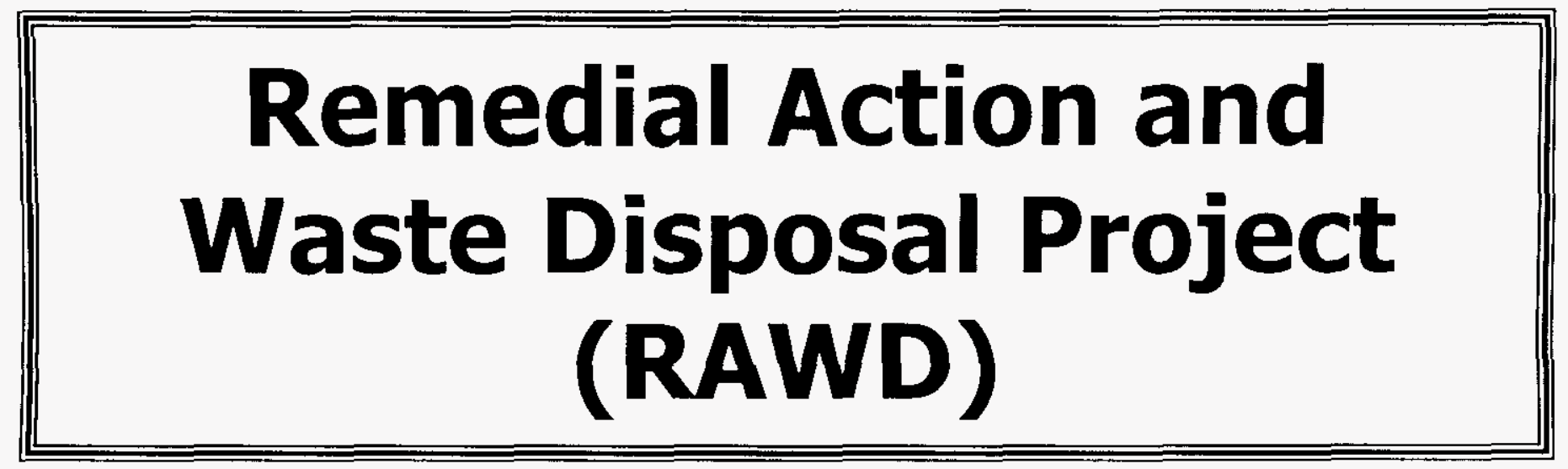




\section{ENVIRONMENTAL. MANAGEMENT PERFORMANCE REPORT ENVIRONMENTAL RESTORATION NOVEMBER 2000}

\section{SECTION B - RESTORING THE RIVER CORRIDOR}

Financial / Performance Measures data as of month-end September. All other data as of October 26, 2000 (unless otherwise noted).

Remedial Action \& Waste Disposal Project (RAWD):

ACCOMPLISHMENTS: RAWD

FYOO SUMMARY

Following is a Summary of Significant Remedial Action and Waste Disposal Project accomplishments achieved during FYo The FYOO accomplishments are grouped into three categories: momantum, progress, alid completion/removal. The Project's top five accomplishments are underlined for acsy recognition.

Momentum: (how Hanford cleanu'p has been "sped up")

Initiated 100 F. Aied remediation actwities on July 10 twclve weeks ahead of schedule (satisfying Tri-Party Agreement Milestone M-16-13A). $100 \mathrm{~N}$ Area remediation activities were also initiated on July 21(satisfying Hanford Site RCRA Permit requirements). The 100 Area Burial Ground ROD received regulatol approval on September 25. All waste sites in the 100 Area are now covered under a ROD which significs cleanup criteria and requirements have been established for the mine reactor aleas along the Columbia River.

Progress: ("things" achieved in terins of amounts or percentages)

Removed over 579,000 metric tons (6 39,000 tons) of contaminated waste in Fro0 and disposed in ERDF. To date over 2.2 mil/ion metric tons $(2.5$ million tons 2 of contaminated waste have been removed and disposed at ERDF since disposal operations began in July 1996.

Completed excavation of 42 contamirated waste sites (FyoO HQ performance measure identified 41 waste sites). This bring: the total waste sites cleaned up to 219 of the 1,547 identified to date $(14 \%)$.

Completed 168 waste site assessments (FY0O HQ performance measure identified 167 assessments). This bings the totai assessments completed to 797 of the 1,547 identified to date $(5 \% \%)$.

Issued a request for proposal to potential bidders for $100 \mathrm{~B} / \mathrm{C}$ Area pipeline remediation on August 23. Bid froposals wert recenction september 29, and technical revicus are uncterway.

Completed soll (likeluding whumes) and pupeline excavation activities in the 100 D Area in suly Over 643,000 metric tons i 709, 000 tims) of contaminated waste were removed and disposed

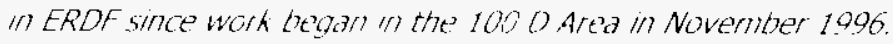

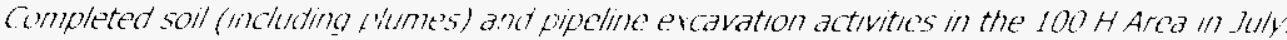

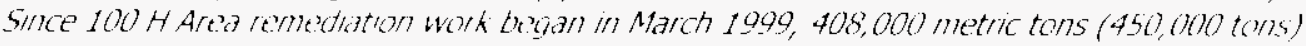
of contammated waste' we'termover' and disposed in ERDF.

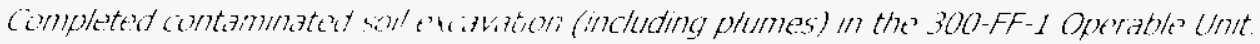

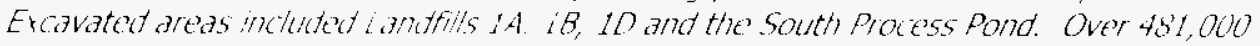
metric tons (531, wo tons) of whiminated waste' we re removed and disposed in ERDF since

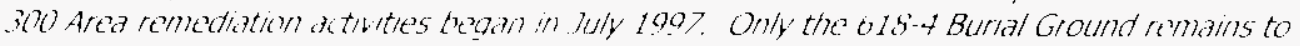
tot $t^{3} t^{3} m t^{2} d / a t t^{2} d$ 


\section{ENVIRONMENTAL MANAGEMENT PERFORMANCE REPORT ENVIRONMENTAL RESTORATION NOVEMBER 2000}

\section{ACCOMPLISHMENTS continued: RAWD}

Initiated procurement activities for the treatment of the 618.4 Burial Ground drummed uranium waste (located in the 300 Area). Bid proposals were submitted in August, and technical reviews are underway. These drums, which contain depleted uranium shavings and oil from past fuel production, were unearthed in 1998 during excavation of the burial ground.

Completed Rev. 0 of the 300-FF. 2 Operable Unit FFS and Proposed Flan, and also supported public comment meetings.

Deployed a geo-probe with a sodium iodide detector for in situ characterization at the 126-F-1 ash pit remediation site, resulting in a potential $50 \%$ reduction of waste. The provect utilized EM-70 return-on-investment funds to deploy this technology.

Transported and disposed the first Spent Nuclear Fuel waste shipnent from $\mathrm{k}$ Basin into ERDF during June.

Placed the first waste shipment into ERDF Cell \#4 in June.

Completed installation of an interim cover over ERDF Cells 1 and 2 . The interim cover is a vapor barrier covered with fill dirt and grass.

Traveled over 7 million kilometers (4.4 million miles) transporting contaminated waste to ERDF without an at-fault accident (one truck rear-ended by non-ER velincle' in .July.) This saticts record exceeds the industry standard.

Completion/Removal: ("what's done and what's gone")

Completed construction of ERDF Cells \$3 and \#4 in December 1999 (satisfying Tri-Party Aqreement Milestone M-16-92B). The two new cells doubled the capacity of waste storage at ERDF.

Completed remediation and backfill of contaminated liquid wastc sites in the $100 \mathrm{~B} / \mathrm{C}$ Arca on? February 25, five weeks ahead of schedule. 100 B/C Area remediation, which beqann in 1996 , was the first remediation work activity initiated by the ERC towards meeting a Tri-Party Agreenent milestone (Tri-Party Agreement Milestone M-16-OBB due March 31). Only pule'lun and burial ground remediation remains in the $100 \mathrm{~B} / \mathrm{C}$ Area.

Completed backfill operations for the Group 2 waste sites (DR high-priority, near-river sitess) and pipeline segments.

Transferred 32 metric tons (35 tons) of excess stee/ rail to a local railcar repair facility for re'use. The rail was removed from the 300 Area South Process Pond to accommodate. plume' remediation. This adtivity supported RL's economic development and wast' mininization progranis.

Completed ERDF disposal of Pacific Northwest National Laboratory (PNNL) 3.31 A Building demolition waste in February. This was the first non-ER waste disposal into ERDF.

\section{SAFETY/ISMS/CONDUCT OF OPERATIONS: RAWD}

see fxecutive Summary. 


\section{ENVIRONMENTAL. MANAGEMENT PERFORMANCE REPORT ENVIRONMENTAL RESTORATION

\author{
NOVEMBER 2000
}

BREAKTHROUGHS/OPPORTUNITIES FOR IMPROVEMENT: RAWD

Following is a summary of significant breakthroughs identified during FYoO.

Waste Minimization 126-F-1 Ash Pit: The project deployed two off-the-shelf technologies (geo-probe and sodium iodide detector' to perform in -situ characterization that resulted in $50 \%$ reduction in waste site volume. Prelimmary cost savings is t'stimated at $55 \mathrm{M}$.

\section{LONG-TERM (6 MONTHS PLUS) IMPORTANT ITEMS: RAWD}

Following is a summary of significant loig-term important items identified during Fyoo:

100 Area Burial Grounds: The Enwirumental Protection Agency (EPA) signed the Record of Decision for the 100 Area Burlai Groulli on Septenber 25. This is the last ROD required for 100 Area Remediation.

MAJOR COMMITMENTS (FISCAL YEAR PLUS 6 MONTHS): RAWD

- DOE Secretarial:

None identified at this time.

- DOE EM Performance Agreemient:

None identified at this time. 


\section{ENVIRONMENTAL MANAGEMENT PERFORMANCE REPORT ENVIRONMENTAL RESTORATION \\ NOVEMBER 2000}

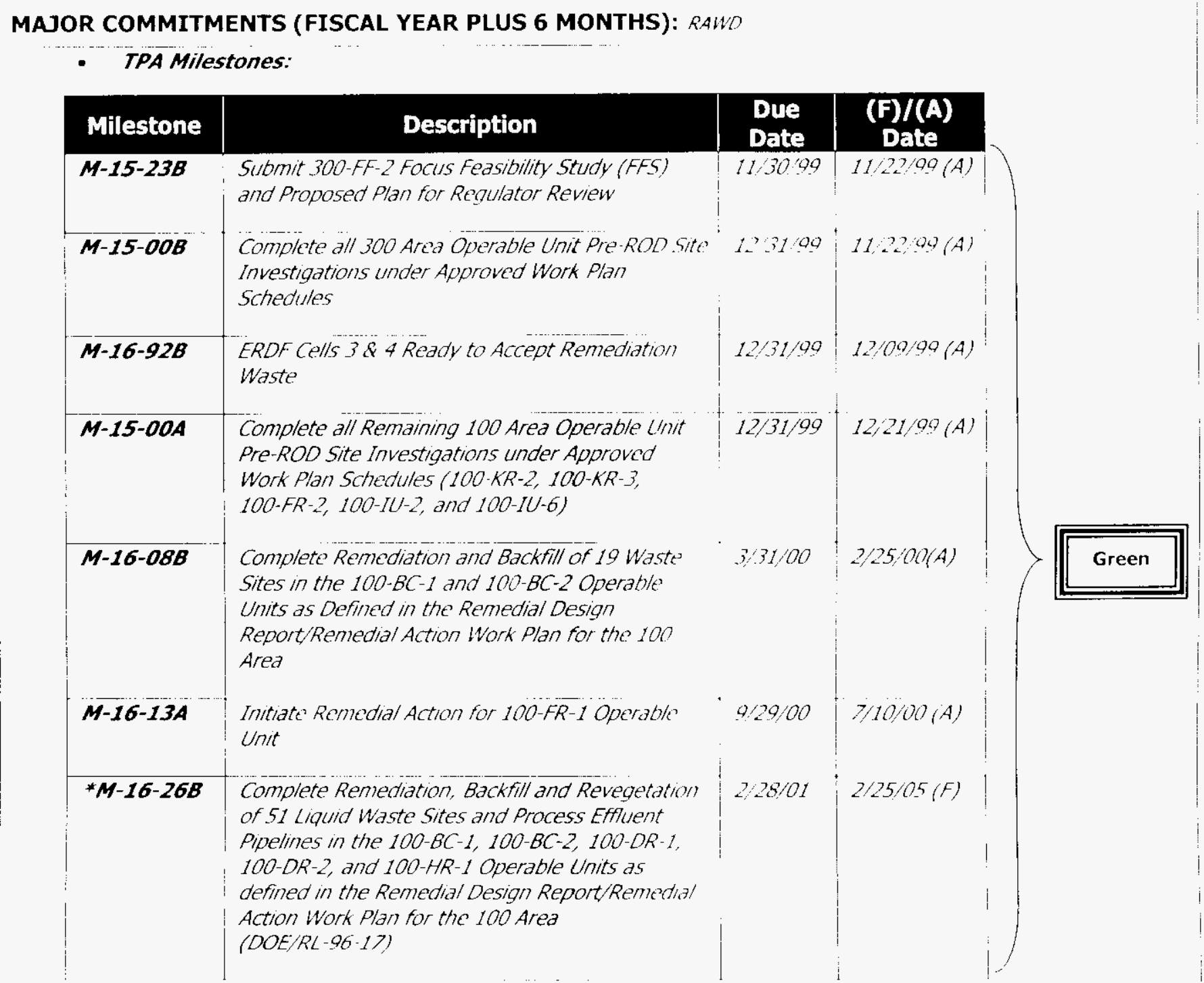

"Unrecoverable due to funding constraints. Bid proposals wele recelved on September 29 for the $100 \mathrm{~B} / \mathrm{C}$ pipeline remediation, and are being evaluated. A Tri-Party Agrecment change' request is being prepared that proposes a new milestone datc' be' chtahlished by danuary. it. 2001, after the subcontract has been awarded.

- DNFSB Commitment:

None idtentified at this time? 


\section{ENVIRONMENTAI. MANAGEMENT PERFORMANCE REPORT ENVIRONMENTAL RESTORATION \\ NOVEMBER 2000}

PERFORMANCE OB.JECTIVES: RAWD

\begin{tabular}{|c|c|c|}
\hline Outcome & Performance Indicator & Status \\
\hline $\begin{array}{l}\text { Restore the River } \\
\text { Corridor for Multiple Uses }\end{array}$ & $\begin{array}{l}\text { 100, } 360 \text {, Alea waste } \\
\text { excaviatom, disposal and } \\
\text { baikfll regrade. }\end{array}$ & $\begin{array}{l}\text { Bastiline work has been } \\
\text { completed per Penformance } \\
\text { Incentive (PI) requirements. }\end{array}$ \\
\hline
\end{tabular}

PERFORMANCE MEASURES: RAWD -- (River and Plateau)

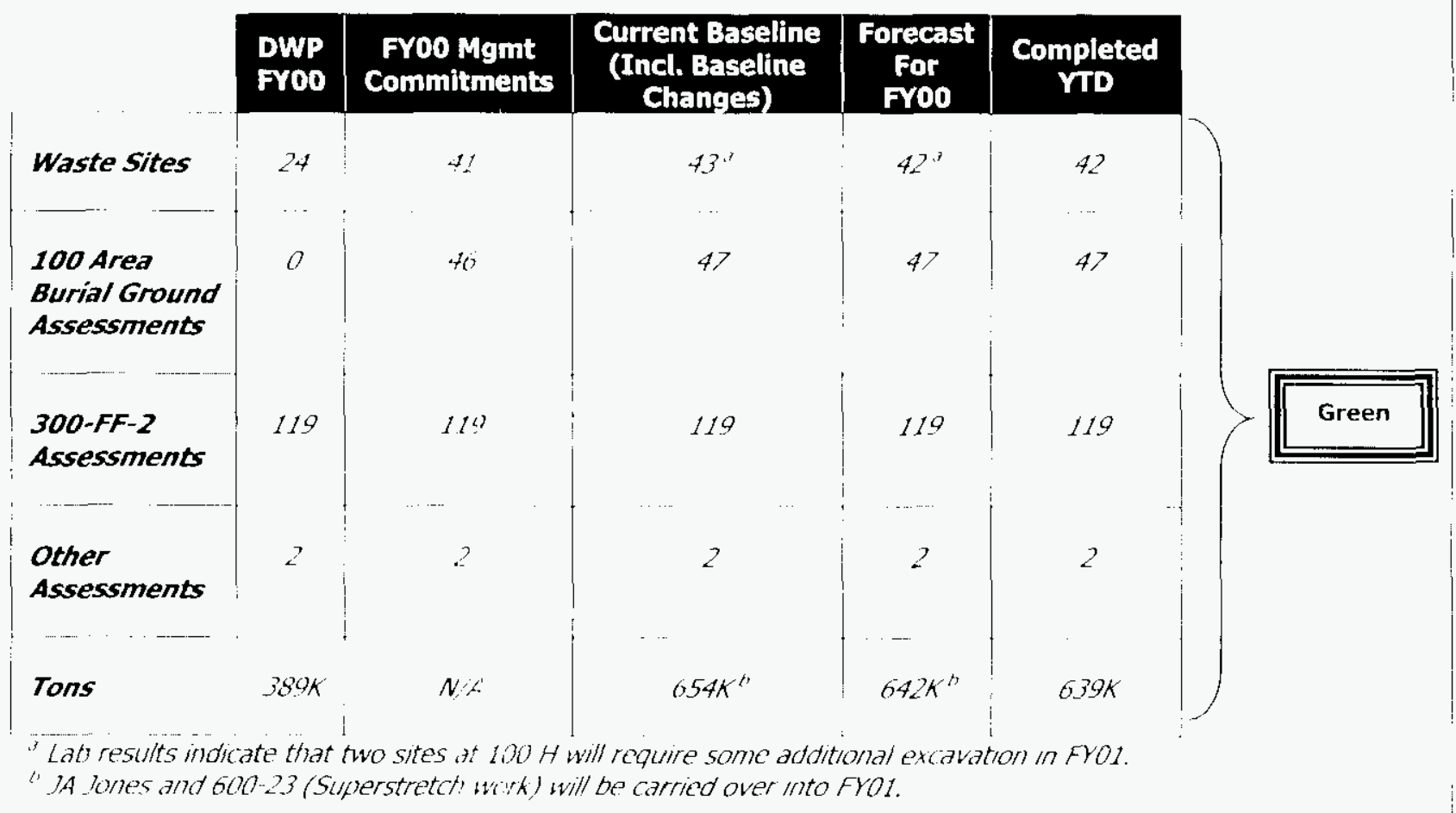




\section{ENVIRONMENTAL MANAGEMENT PERFORMANCE REPORT ENVIRONMENTAL RESTORATION \\ NOVEMBER 2000}

STRETCH AND SUPERSTRETCH GOALS: RAWD

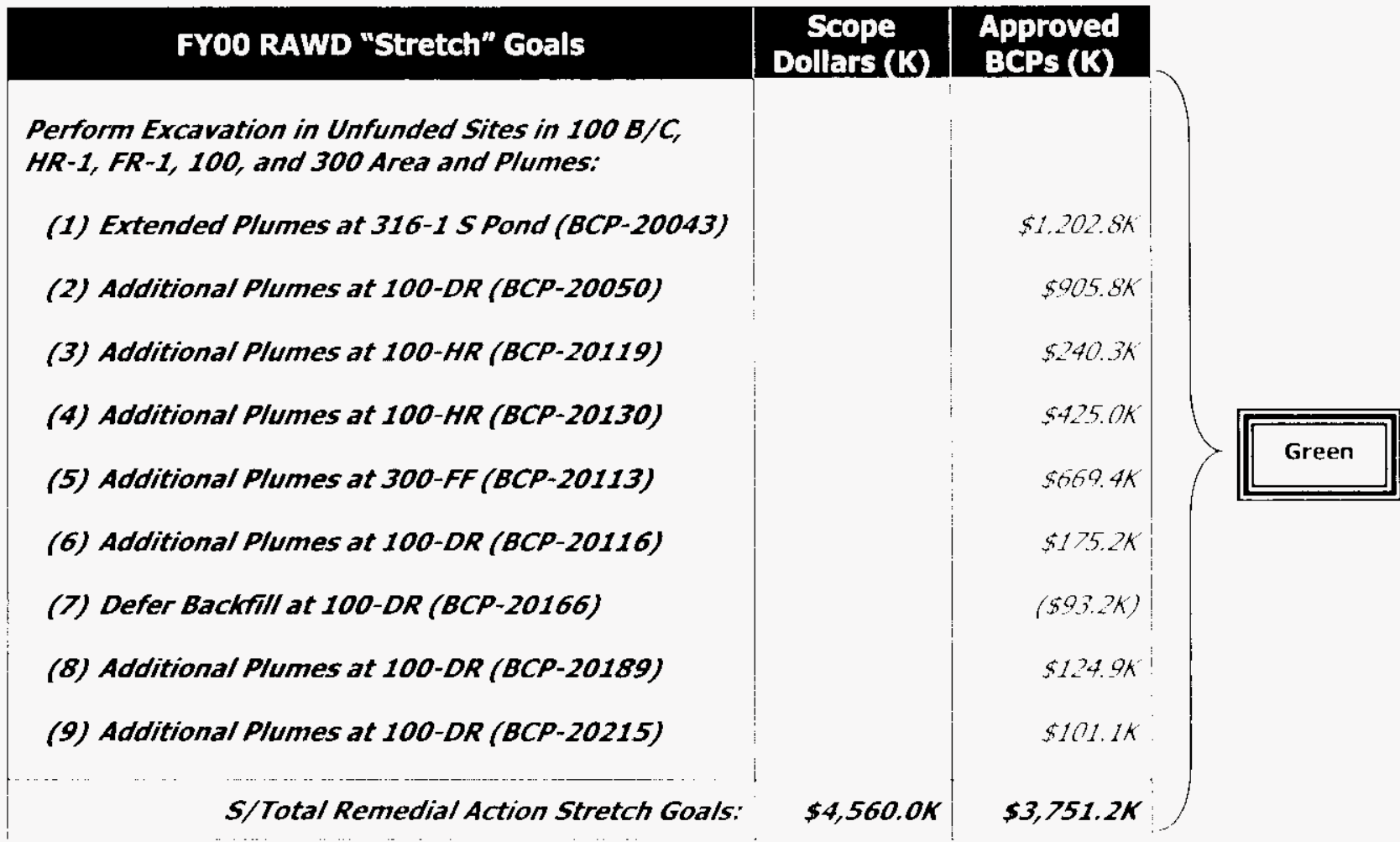

\section{FYOO RAWD "Superstretch" Goals}

Scope

Approved Dollars (K) BCPs (K)

Complete Remediation of 60 Sq. Mi. of Hanford Site:

(1) Complete Remediation of Hanford Townsite

(2) Complete Remediation of JA Jones Pit \#1 and $600-23(300-F F-2) *$

(3) Other Remedial Actions

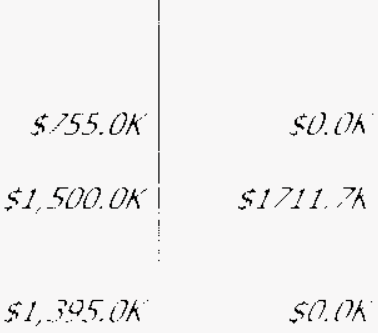

S/Total Remedial Action Superstretch Goals:

$\$ 3,650.0 \mathrm{~K}$

$\$ 1711.7 K$

"Status: BCP-20270 endorsed by DOE-RL Assistant Manager for Envirumental Restoratill \& Waste Management (AMFW) for $\$ 1,707.1 \mathrm{~K}$ on August 10. Work is scherduled for complethen.

"Efficiencies applied to Superstretch projects in Groundwater Mandagt'ment and

Decommissioning Projects. 


\section{ENVIRONMENTAL MANAGEMENT PERFORMANCE REPORT \\ ENVIRONMENTAL RESTORATION \\ NOVEMBER 2000}

\section{PROJECT STATUS (COST/SCHEDULE/MAJOR BASELINE CHANGE: RAWD}

- Schedule:

\begin{tabular}{|c|r|r|r|}
\hline \multirow{2}{*}{ Remedial Action \& Waste Disposal Project } & \multicolumn{1}{c|}{ BCWS } & \multicolumn{1}{c|}{ SCWP } & Variance \\
\cline { 2 - 5 } & $\mathbf{\$ K}$ & $\mathbf{\$ K}$ & $\mathbf{\$ K}$ \\
\hline ER01 100 Area Remedial Actions & 30,358 & 28,682 & $-1,676$ \\
\hline ER03 300 Area Remedial Actions & 6,676 & 6,291 & -385 \\
\hline ER04 ER Waste Disposal & 20,555 & 20,197 & -358 \\
\hline
\end{tabular}

PBS-ERO1 - 100 Area Remedial Action

Schedule Variance $=-\$ 1676 K ;-5.5 \%$ [Last Month: $-\$ 669 K ;-2.5 \%$ ]

Cause: 100-DR south pipelinc confirmation sampling behind schedule due to design document preparation delay.s; start of $D R$ north pipeline backfill delayed pending resolution of differing chromium lab results; efficiencies allowed Superstretch remediation sites (JA Jones and 600-23) to be initiated in FYOO, but major work activities are in FYO1 (plannea SV/carryover).

Resolution: South pipeline sampling design has been completed and variance sampling is in progress. Confination sampling will be carried over for completion in early Frol.

PBS-ERO3 - 300 Area Remedial ACtion

Schedule Variaice $=\mathbf{\$ 3 8 5 K} ;-\mathbf{5 . 8 \%}$ [Last Month: $-\$ 233 K ;-3.7 \%$ ]

Cause: Procurcment packac'e for drum disposal is behind schedule duc to additional evaluation time requested by the prospective bidders. 300-FF-1 verification packages on hold pending regulator determination of format revision.

Resolution: Project unabie to recover procurement delay. RL working with regulators on package requilchinents; remaining work will be carried over to Frol for completion.

\section{PBS-ERO4 - Environmental Restoration Waste Disposal}

Schedule Variance $=-\$ 358 K ;-1.7 \%$ [i.ast Month: $+\$ 60 K ;+0.3 \%)$

Cause: Waste disposal for 14 lynes and 600-23 multi-ycar Superstretch sites scheduled for frot.

Resolution: None requreat. whescope will be carried over to fyol for completion. 


\section{ENVIRONMENTAL MANAGEMENT PERFORMANCE REPORT ENVIRONMENTAL RESTORATION NOVEMBER 2000}

PROJECT STATUS (COST/SCHEDULE/MAJOR BASELINE CHANGE continued: RAWD

- Cost:

\begin{tabular}{|c|c|c|c|c|}
\hline \multirow{2}{*}{ Remedial Action \& Waste Disposal Project } & BCWP & ACWP & Variance & \\
\hline & $\$ K$ & $\$ K$ & $\$ \mathbf{K}$ & \\
\hline ERO1 100 Area Remedial Actions & $29,69 \%$ & 23,751 & +931 & \\
\hline ERO3 300 Area Remedial Actions & 0,291 & 4,794 & 1,497 & Green \\
\hline ERO4 ER Waste Disposal & 20,197 & 18,324 & 1,873 & \\
\hline TOTAL Remedial Actions & 55,170 & 46,869 & 8,301 & \\
\hline
\end{tabular}

PBS-ERO1 - 100 Area Remedial Action

Cost Variance $=\mathbf{\$} \$ 931 \mathrm{~K} ;+\mathbf{1 7 . 2 \%} /$ Last Month: $+\$ 4166 k ;+16.3 \% \mathrm{~K}$

Cause: More efficient asbestos abatement methods utilized (asbestos and piping removed and disposed concurrently) in 1000 and ty Areas; savings in sampling and analyses by using local laboratory and on-site resources; F Area savings in site prep and reallocating resources between Fand H Areas; labor savings on $B / C$ backill activities; lower costs for $116-N-1$ design.

Resolution: Savings were used to perform other remediation work.

PBS-ERO3 - 300 Area Remedial Action

Cost Variance $=\mathbf{+ \$ 1 4 9 7 K ;}+\mathbf{2 3 . 8 \%}$ [Last Month: $+\$ 1314 \mathrm{~K} ;+21.4 \%$ i.]

Cause: Savings in Landfill $1 A / 1 B$ remediation (such as working two sites concurrently, less down time, less Level B protection); FYg9 accrual reversal in South Process Pond remediation.

Resolution: Savings were used to perform other remediation work.

PBS-ERO4 - Environmental Restoration Waste Disposal

Cost Variance $=+\$ \mathbf{\$ 8 7 3 \kappa ;}+\mathbf{9 . 3 \%}$ [Last Month: $+\$ 2157 ;+11.4 \%$ ]

Cause: ERDF cover design and construction closeout completed with fewer resources than planned, transportation cost efficiencies from mild winter; and Fyog over accrual.

Resolution: Savings were used to perform other remediation work.

\section{REGULATORY ISSUES: RAWO}

A number of significant issues were identified and resolved durng Fyon. Those remalning at fiscal year end include.

Tri-Party Agreement Milestone M-16-26B: An outyear milestont, M"16-266, "Complete Remediation, Backfill, and Revegetation of 51 Liquid Waste Sites and Process Effluent Pipelines

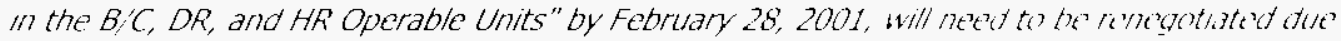
to lack of funding in FYg9 and FYOO for $100 \mathrm{~B} / \mathrm{C}$ pipeline remediathon a tivities, and the arsenic issue at the $100 \mathrm{H}$ Area.

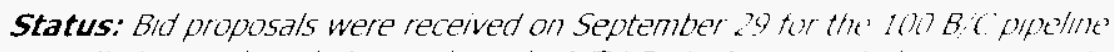

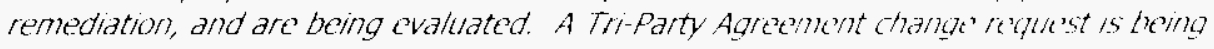

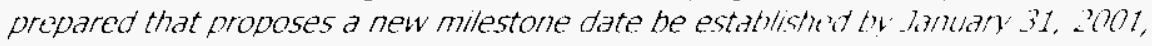
after the subcontract has been awarded. 


\section{ENVIRONMENTAL. MANAGEMENT PERFORMANCE REPORT ENVIRONMENTAL RESTORATION \\ NOVEMBER 2000}

REGULATORY ISSUES continued: RAWD

Tri-Party Agreement Milestone M-16-26C: M-16-26C, "Complete Remediation and Backfill of 10 Liquid Waste Sites and Process. Efituent Pipelines in the 100-HR-1 Operable Unit" by May 31, 2001, will need to be renegotiated ' 'ue to additional phumes and unanticipated elevated arsenic levels encountered during confirmation sampling/verification activities. Elevated levels of chromulm are also being encountered that are above the remedial action goals.

Status: When the impact of the elevated chromium results is evaluated, a Tri-Party agreentent change package wil be prepared.

100 D Area Backfill: Backfill concuricice for the remaining north segment of the 100-DR north pipeline continues to be delayed prending resolution of a chromium issue. Additional samples have been collected and independently analyzed by three laboratories, with conflicting results. Ecology prefers that another qualificed laboratory be utilized for further analysis.

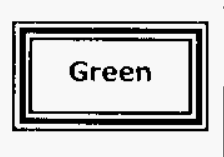

Status: Samples were sent to a fourth qualified laboratory for anialysis. Based on results, a strategy will be deve'oped to achieve final resolution of this issue.

EXTERNAL ISSUES (i.e. HAB, Congress, etc.): RAWD

None identified al this time.

DOE-RL \& HQ ISSUES/REQUESTS (not covered elsewhere): RAWD

None identified at this time.

\section{INTEGRATION ACTIVITIES: RAWD}

Following is a summary of significant integration activities identified during Froo:

ERDF: In support of Hanford Site partharng, draft waste shipping and recening plans (WSRPS) were prepared for the two initial waste streams expected from the Spent Nuclear Fuel (SNF) Project's K Basin clean out work. Initial delivery of waste from the SNF began on June. 26.

3314 Facility: The ERDF successfuli' completed handling its first waste stream from outside the ERC. Transportation and disposal oi demolition waste from the 331 - A building took place from February 21 to March 6. The demolition contractor, Fluor Federal Services, experienced an equipment-related delay that stretched the completion date out further than onginally anticipated. Tearning and coordination between all parties (PNNL, Flior, DRD and RAWD) was excellent and the job procceded smoothiy. A lessons learned/feedback meeting was held to identify how ERDF processe's can be ontimized.

$\boldsymbol{K}$-Basin Waste: ERDF personmel in somynction with members of the Spent Nuclear Fuels Project Tean intiated and implemerited a successful waste shipment program in support of $k$ Basin Wastes. Shipments began in unik' and contmich as required.
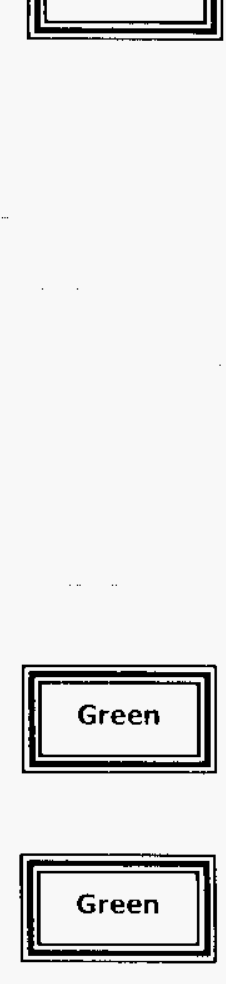


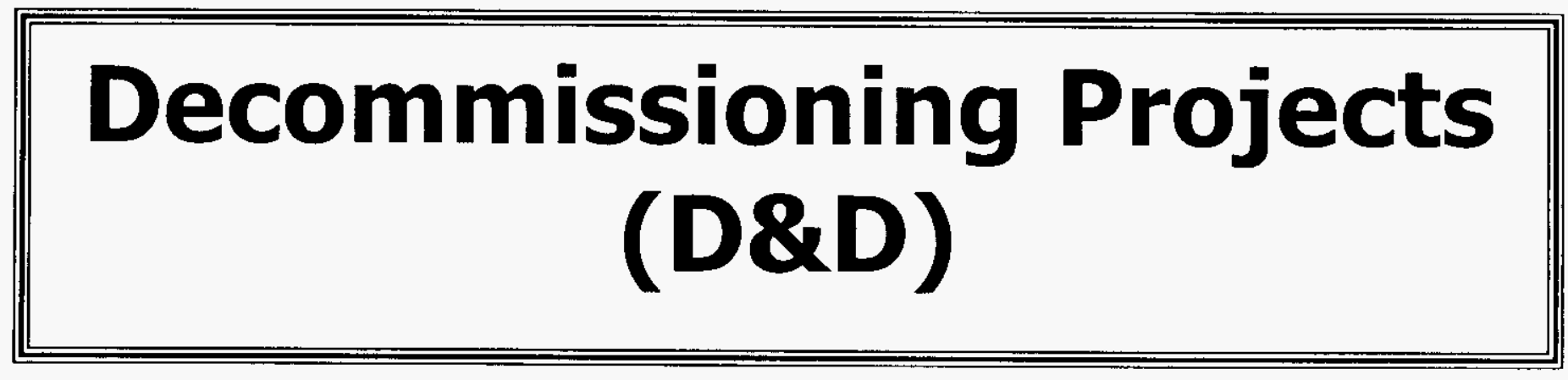




\section{ENVIRONMENTAL. MANAGEMENT PERFORMANCE REPORT \\ ENVIRONMENTAL RESTORATION \\ NOVEMBER 2000}

\section{SECTION B - RESTORING THE RIVER CORRIDOR}

Financial / Performance Measures data as of month-end September. All other data as of October 26, 2000 (unless otherwise noted).

\section{Decommissioning Projects (D\&D)}

\section{ACCOMPLISHMENTS: $D \& D$}

FYOO SUMMARY

Following is a summary of significant Decommissioning Project accomplishments achicved during FYOO. The FYOO accomplishments are grouped into three categories: momentum, progress, and completioniremoval. Ihe Project's top five accomplishments (reactor and 233 -5 each) are underlined for easy recogintion.

Momentum: (how Hanford cleanup has been "sped up")

ISS:

Completed demolition of the remaining ancillary structures for both Fand DR Reactors, except for the F Reactor fuel storage basin (ISSB) and DR Reactor FSB stairwells. Demolition of the F Reactor FSB beqan on September 25 and demolition of the DR Reactor staimells began on October 20. F Reactor interim safe storage (ISS) is schedulect for completion in 2002 (one year ahead of schedule). DR Reactor 155 is scheduled for completion in 2001 (four years ahead of schedulel.

Completed D and H Reactor presunezs walkdowns, estimates, and biological cleanup activities and issued all required D and H Reactors' enginecring documents for review prior to Intiating ISS demolition activitios in. FYCI laccelerated from 2004 [D Reactor] and $20061 \mathrm{H}$ Reactorll:

Progress: ("things" acticved in terns of amounts or percentages)

ISS:

Completed characterization of the tox 5 meters (17 feet) of fill in the F Reactor FSB. Engineering for removal of fill debris in the F Reactor $F S B_{\text {a }}$ along with agreements to handle ally spent nuclear fuel found in Fand ti Reactor FSBS, waS also completed.

Completed $90 \%$ of the safe storage enclosure pourbacks required for the F and DR Reactors.

233-S P/utonium Concentration Facility:

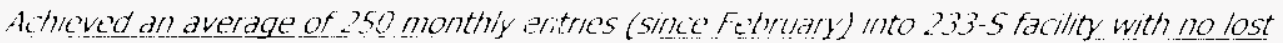
workdays occurring.

Completed loadout hood dismantlemeni and decontamnination activities.

Completed dry cleanup and gross derontamination of the process hood floor. A total of 51 wolyars $(0.5$ fiter in siat') containing loose material was collected.

Completed remowal and disposal (to tRofl of 59 meters (10; feet) of exhaust and supply roof

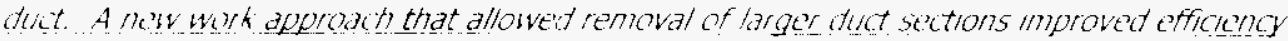

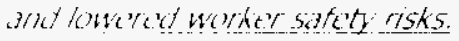

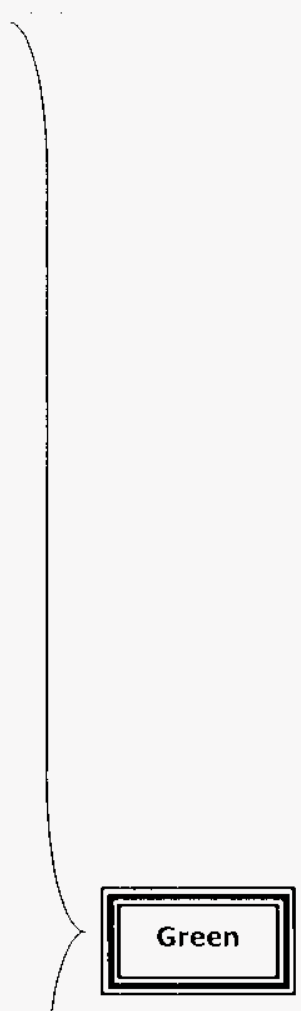




\section{ENVIRONMENTAL MANAGEMENT PERFORMANCE REPORT ENVIRONMENTAL RESTORATION \\ NOVEMBER 2000}

ACCOMPLISHMENTS continued: $D \& D$

Completed removal of a total of 19 lines from the viewing roon south end pipe trench.

Completed removal of all 70 PMMA panels from the process hood.

Completed removal of all piping, valve canisters, conduit, and pane's from the instrument loft in the viewing room.

224-B Plutonium Concentration Facility: (Halted decomminssioning activities in May due to higher priority work)

Submitted the draft engineering evaluation/cost analysis (EE/CA) for regulator review.

Completed initial radiological survey and walkdown of the 224-B offices and storagt areas.

Completion/Removal: ("what's done and what's gonc")

ISS:

Completed Project Closeout reports for four facilities including the 10 g- F Blological Laboratory, 119-DR Exhaust Air Filter Sampling Building, 116-D and 116-DR exhaust stack demolitions. Demolition of these structures was accelerated from outyears and was completed in FYg9. Submittal of the closeout reports formally constitutes completion of facility demolition.

Completed F Reactor Hazards Assessment and Characterization Report (satisfying Try-Party Agrecment Target Milestone M-93-08-T01).

B Reactor:

Completed B Reactor Museum Feasibility Assessment (Phase II) Project document (satisfying Tri-Party Agreement Milestone M-93-05). Supplemental cost estimates for hazard mitigation! were also completed.

SAFETY/ISMS/CONDUCT OF OPERATIONS: $D \& D$

Sece Executive Summary.

BREAKTHROUGHS/OPPORTUNITIES FOR IMPROVEMENT: $D S D$

Following is a summary of significant breakthroughs identified durng froo.

233-S: The 233-S Radiological Control group is utilizing a digital camera and photo editing software to place actual photographs of survey locations into Radiological Control Survil Records. This provides the workers with an actual work location picture with radiological survey information annotated on the document. This has given them a hetter physical understanding of the potential hazards.

LONG-TERM (6 MONTHS PLUS) IMPORTANT ITEMS: $D \& D$

None identified at this time. 


\title{
ENVIRONMENTAL. MANAGEMENT PERFORMANCE REPORT ENVIRONMENTAL RESTORATION NOVEMBER 2000
}

MAJOR COMMITMENTS (FISCAL YEAR PLUS 6 MONTHS): $D \& D$

- DOE Secretarial:

None identified at this time.

MAJOR COMMITMENTS (FISCAL YEAR PLUS 6 MONTHS) continued: $D \& D$

- DOE EM Performance Agreement:

None identified at this time.

- TPA Milestones:

\begin{tabular}{|c|c|c|c|c|}
\hline Milestone & Description & Due Date & $\begin{array}{l}(\mathrm{F}) /(\mathrm{A}) \\
\text { Date }\end{array}$ & \\
\hline$* M-93-05$ & $\begin{array}{l}\text { Issue B Reactor Phase II Feasibility Study } \\
\text { Engineering Design Report for Public Comment }\end{array}$ & $6 / 30 / 00$ & $7 / 10 / 00(A)$ & Green \\
\hline
\end{tabular}

*The B Reactor milestone deliverable wias submitted to DOE-RL (PM) on June 27 and delivered to the DOE-RL Office of Regulatory Liaison on June 28 for concurrence and submittal through the remainder of the signature cycle. The document was received by the regulators on July 10, ten days later than the milestone completion date of June 30. An EPA letter received on

huly 25 documented comments on the content of the document.

\begin{abstract}
Status." RL responded to EFA S comments on August 1. The letter reaffirmed RL'S commitment to deliver Draft A Engineering Evaluation/Cost Analysis (EE/CA) to EPA by January 31, 2001. Support will also be provided with the public comment period and through the approval of the Action Memorandum. EPA concurred that all requirements for TPA Milestone M-93-05 and EPA's comments had been addressed. In subsequent meetings witn DOE and EPA, it has been agreed to move the Draft $A$ EE CA deliverable date to A fri' 30, 2001 due to the additional alternatives being considered.
\end{abstract}

- DNFSB Commitment:

None identified at this time.

PERFORMANCE OBJECTIVES: $D \& D$

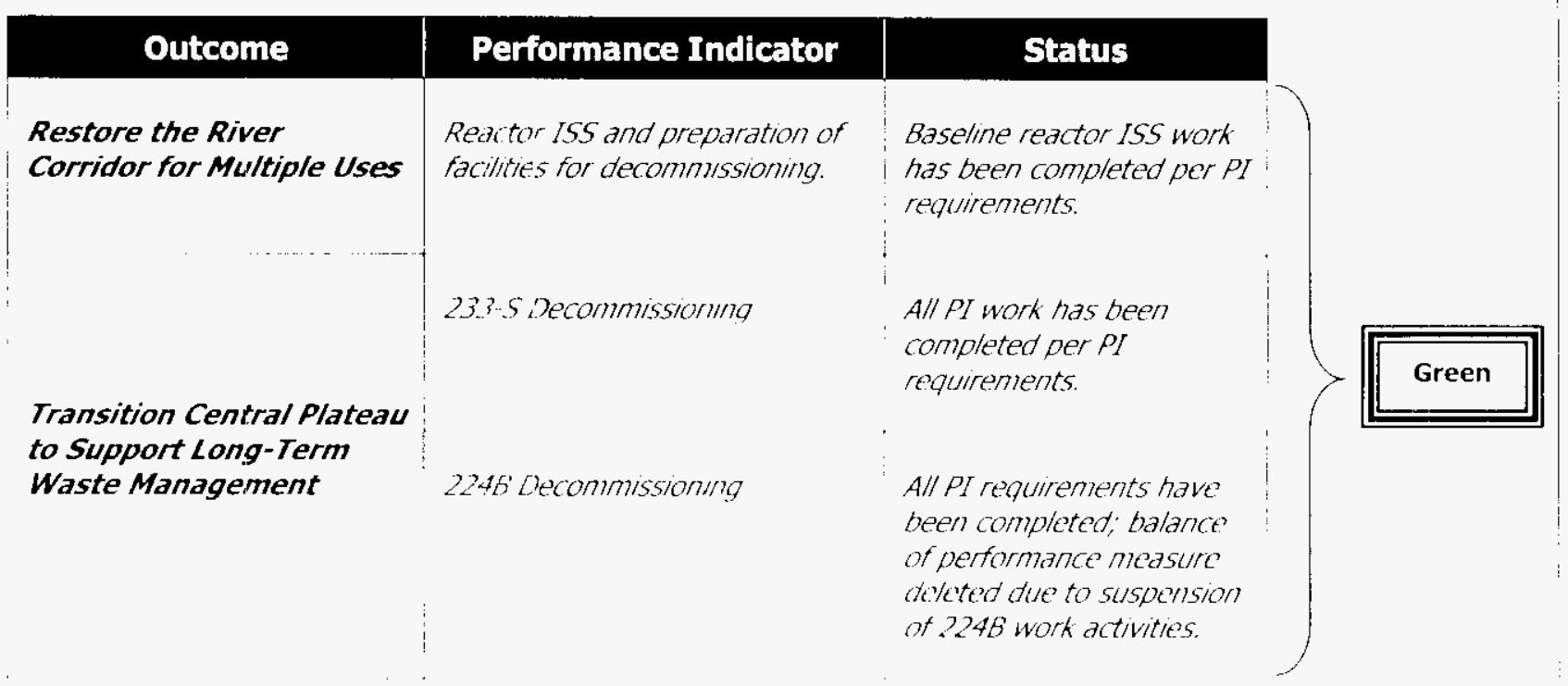




\section{ENVIRONMENTAL MANAGEMENT PERFORMANCE REPORT \\ ENVIRONMENTAL RESTORATION \\ NOVEMBER 2000}

PERFORMANCE MEASURES: $D \& D$

\begin{tabular}{|l|c|c|c|c|c|}
\hline & $\begin{array}{c}\text { DWP } \\
\text { FY00 }\end{array}$ & $\begin{array}{c}\text { FY00 Mgmt. } \\
\text { Commitments }\end{array}$ & $\begin{array}{c}\text { Current Baseline } \\
\text { (Incl. Baseline } \\
\text { Changes) }\end{array}$ & $\begin{array}{c}\text { Forecast } \\
\text { For } \\
\text { FY00 }\end{array}$ & $\begin{array}{c}\text { Completed } \\
\text { YTD }\end{array}$ \\
\hline Facilities & 0 & 0 & 4 & 4 & 4 \\
\hline
\end{tabular}

Green

"116-D, 116-DR, 119-DR, and 108-F.

STRETCH AND SUPERSTRETCH GOALS: $D \& D$

\begin{tabular}{|c|c|c|}
\hline FY00 D\&D "Superstretch" Goals & $\begin{array}{c}\text { Scope Dollars } \\
\text { (K) }\end{array}$ & $\begin{array}{l}\text { Approved } \\
\text { BCPs (K) }\end{array}$ \\
\hline $\begin{array}{l}\text { Contimue F Reactor Interim Safe Storage (ISS) } \\
\text { (BCP-20151) }\end{array}$ & $\$ 2,000.0 K$ & $\$ 1,490.8 K$ \\
\hline $\begin{array}{l}\text { *Public Access to Hanford Townsite and B } \\
\text { Reactor }\end{array}$ & $\$ 750.0 k$ & $50.0 k$ \\
\hline S/Total D\&D Superstretch Goals: & $\$ 2,750.0 K$ & $\$ 1,490.8 K$ \\
\hline
\end{tabular}

Klein on 9/20/00 outlining options and costs for public access via bike path and boat dock.

\section{PROJECT STATUS (COST/SCHEDULE/MAJOR BASELINE CHANGE): $D \& D$}

\begin{tabular}{|c|c|c|c|}
\hline Schedu/e: & \multicolumn{1}{c|}{ BCWS } & \multicolumn{1}{c|}{ BCWP } & Variance \\
\cline { 2 - 5 } Decommissioning Projects & \multicolumn{1}{c|}{$\mathbf{\$ K}$} & $\mathbf{\$ K}$ & \multicolumn{1}{|c|}{$\mathbf{K}$} \\
\hline ERO6 Decontamination \& Decommissioning & 17,129 & 15,420 & $-1,709$ \\
\hline Total D\&D & 17,129 & 15,420 & $\mathbf{- 1 , 7 0 9}$ \\
\hline
\end{tabular}

PBS-EROG - Decontamination and Decommissioning

Schedisle Variance $=-\$ 1709 k ;-10.0 \%$ Last Month: $-\$ 20 \% ;-1.4 \% \mathrm{~J}$

Cause: Efficiencies allowed F Reactor ISS scope (Superstret(ch) to be initiated with completion planned for FYO1; 233-5 decommissioning: disposal of duct delayed pending approval of asbestos abatement plan. Ventilation system modificiations at' required at the $233-5$ project.

Resolution: Superstretch work will be carried over to flyl for completion: a basse'/nne' change proposal has been submitted to performing ventilation systen modifications. 


\section{ENVIRONMENTAL MANAGEMENT PERFORMANCE REPORT ENVIRONMENTAL RESTORATION \\ NOVEMBER 2000}

PROJECT STATUS (COST/SCHEDULE/MAJOR BASELINE CHANGE) continued: DED - Cost:

\begin{tabular}{|c|c|c|c|}
\hline \multirow{2}{*}{ Decommissioning Projects } & BCWP & \multicolumn{1}{c|}{ ACWP } & Variance \\
\cline { 2 - 4 } & $\mathbf{\$ K}$ & $\mathbf{\$ K}$ & $\mathbf{\$ K}$ \\
\hline ER06 Decontamination \& Decommissioning & 15,420 & 15,376 & $\mathbf{1 5}$ \\
\hline TOTAL D\&D & $\mathbf{1 5 , 4 2 0}$ & $\mathbf{1 5 , 3 7 6}$ & $\mathbf{4 4}$ \\
\hline
\end{tabular}

PBS-EROG - Decontamination and Decommissioning

Cost Variance $=\mathbf{+ \$ 4 4} \boldsymbol{\mathbf { 4 }} ;+\mathbf{0 . 3 \%}$ [Last Month: $+\$ 291 k ;+2.1 \%$ ]

Cause: F and DR ISS sampie analysis costs are significantly lower than expected due to utilizing larger data groups ieconomies of scale).

Resolution: Savings were used to perform other remediation work.

Cause: 233.5 - Additional cost to correct aifflow and installing electrical upgrades in the viewing room.

Resolution: Cost overruns were trended and are reflected in the project EAC.

REGULATORY ISSUES: $D Q D$

A number of significant issues were kentified and resolved during fyoo. Those remaining at fiscal year end include:

D and H Reactor Impacts of TPA Milestones: The acceleration of the reactor ISS projects is no longer consistent with the current M 93 milestones, especially the? competitive procurement anu' renegotiating milestone (M-93-12) for DR Reactor.

Status: Initial discussions with the regulators have begun which should lead to resolution in the near future. This will need to be discussed as part of RL'S 100 Area acceleration vision.

Demolition Equipment: Demolition equipment (track hoe excavators and shuttle truck) breakdowns continue to cause delay's to demolition activities.

Status: Mechanics continue to repair the equipment as quickly as possible. Impact sheets are being completed to track the delays. ISsues/impacts were presented to the Results Mandigement Tian: (RMT). Based on information provided, the fleld Support organization was dirscted to prepare a procurement plan for purchase of it new excavator. Procurement is evaluating a path forward tor purchase of the equipment. \$1.2M for purchase of an excavator and shear is included on the Fyol supplemental funding list.

EXTERNAL ISSUES (i.e. HAB, Congress, etc.): $D \& D$

Nonc hentified at this time.

DOE-RL \& HQ ISSUES/REQUESTS (not covered elsewhere): $D \& D$

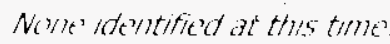

INTEGRATION ACTIVITIES: $D \& D$

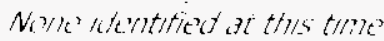




\section{ENVIRONMENTAL MANAGEMENT PERFORMANCE REPORT}

ENVIRONMENTAL RESTORATION

NOVEMBER 2000

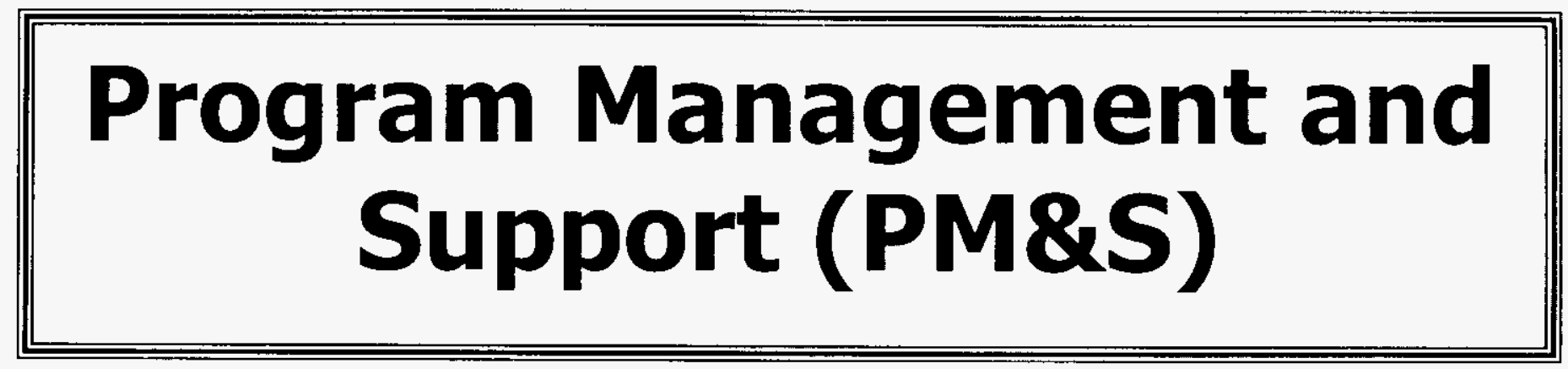




\section{ENVIRONMENTAL MANAGEMENT PERFORMANCE REPORT ENVIRONMENTAL RESTORATION \\ NOVEMBER 2000}

\section{SECTION B - RESTORING THE RIVER CORRIDOR}

\section{Financial / Performance Measures data as of month-end September. All other data as of October 26, 2000 (unless otherwise noted). Program Management \& Support (PM\&S)}

\section{ACCOMPLISHMENTS: PM\&S}

\section{FYOO SUMMARY}

Following 15 a summary of significant Program Management and Support Project accomplishments achieved during FYOn. The FYOO accomplishments are grouped into three categorles: momentum, progress, anct completion/removal. The Project's top five. accomplishments are underlined for eass recognition.

Momentum: (how Hanford cleanup has been "sped up")

Completed 9 technology deployments ifyoo HQ performance measure identified 4 technology deployments). These deployments were instrumental in providing efficiencies in the efforts of waste site remediation, reactor ISS, and CDI characterization activities.

Progress: ("things" achieved in terms of amounts or percentages)

Completed and received HQ approval of the Fyoo Baseline Update and Reconcliation change proposal. The Integrated Priority List , foi the FYO2 budqet submittal was also completed.

Conducted FYO1 f YO3 DWP managennent review meetings with ERC, RL, HQ regulators, and stakeholders to reach agreement on tiuture workscope. The FYO1-FYO3 DwP was approved on Septembir 26. The Zvolume documint establishes the basis for FYol ER work execution.

Exceeded Fyoo Small Business socioeconomic contractual goals. All small, small disadvantaged, and women-owned smal! business prime contract goals have been met or exceeded for the entire six vears of BII's prime contract. In addition, this past year BHI was recogniact as having the be'st small bu'siness statistics in Bechtel Systerns and Infrastructure (parent company of $B H[$ ].

Completed HQ Integrated Planning, Accuntability, and Budget System Part B budget formulation ciata for FrOL?

Complete't the 100 Area and the 200 West Area inspections as required by the Hanford Site RCRA permit. No concerns or violathor's were noted as a result of the inspertions. The semiannual stte'-wide. RCRA inspection of the Columbia River durng high wati' was also conducted whth no (ancerns noted.

completed 50 environmental complicance assessments/survellances/audits.

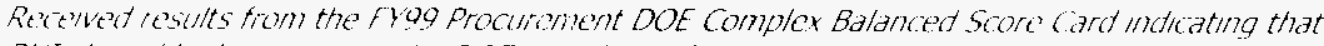
BHI shial'd highest scort in the DOE colinplex in four of the eleven tracked categories.

Recervest recognition from the Secretaly of Energy with a Certificate of Appraciation for contributions to DSEE's misson to prevent pollution in operations, processe's, and proarams. 


\title{
ENVIRONMENTAL MANAGEMENT PERFORMANCE REPORT ENVIRONMENTAL RESTORATION NOVEMBER 2000
}

ACCOMPLISHMENTS continued: $P M \& S$

Completion/Removal: ("what's done and what's gone")

Maintained a major sustained effort across all ERC projects and functional departinchts on implementing, maintaining, and improving our Integrated Environment, Safety, and Health Management System (ISMS). Initial efforts focused on preparing for and supporting DOE verification of our ISMA and addressing opportunities for improvenlent. The Phase II verification audit, which was conducted by a DOE-led team. was sircessfully completed and resulted in no major findings.

Completed successful Y2K transition. All aspects of Y2K operations performed exceptionally well through the rollover weekend to ensure operations were ready for the first days of business in 2000.

Accomplished emergency reposting of the 100 B/C controlled ared and the 200 Arca $216-5$ ditch within a week of the Hanford Site range fire in June. Over 250 ERC signs were darnaged by the fire.

Completed targets for the Waste Minimization performance incentive including redeplovnient of a concrete crusher to Ohio, recycling absorbents, recycling flat bert traller and genfrator, and recycling 100 drum overpacks.

\section{SAFETY/ISMS/CONDUCT OF OPERATIONS: PMES}

See Executive Summary.

BREAKTHROUGHS/OPPORTUNITIES FOR IMPROVMENT: PM\&S

\author{
None identified at this time.
}

\section{LONG-TERM (6 MONTHS PLUS) IMPORTANT ITEMS: PM\&S}

\author{
None identified at this time.
}

MAJOR COMMITMENTS (FISCAL YEAR PLUS 6 MONTHS): PM\&S

- DOE Secretarial:

None identified at this time.

- DOE EM Performance Agreement:

None. dentified at this time.

- TPA Milestones.

None identified at this time.

- DNFSB Commitment:

None identified at this time.

PERFORMANCE OBJECTIVES: PMRS

Nont. 'dentified at this time. 


\section{ENVIRONMENTAL MANAGEMENT PERFORMANCE REPORT ENVIRONMENTAL RESTORATION \\ NOVEMBER 2000}

\section{PERFORMANCE MEASURES: PM\&S}

BHI cominitted to peform four technology deployments for FYoO. A list of planned/committed Froo technology deployments was tranimitted to RL on January 27. Nine technology deployments have been completed through September.

\begin{tabular}{|c|c|c|c|}
\hline Technology Deployment & PBS & $\begin{array}{l}\text { Planned } \\
\text { Date }\end{array}$ & $\begin{array}{c}\text { (F)/(A) } \\
\text { Date }\end{array}$ \\
\hline $\begin{array}{l}\text { Small Diameter Geographical Logging System } \\
\text { (ROI Funded) }\end{array}$ & $R L-E R O 1$ & $10 / 99$ & $10 / 99(A)$ \\
\hline Liquid-Level Detection Technology (Ultrasonics) & $R L-E R O 5$ & $10 / 99$ & $10 / 99(A)$ \\
\hline $\begin{array}{l}\text { Remote Concrete Sampling System (Brokk }{ }^{\mathrm{\top} M} \\
\text { with automated concrete coring attachment) }\end{array}$ & $R L-E R O 5$ & $03 / 00$ & $09 / 00(F)^{.7}$ \\
\hline 3-D Visual and Gamma Ray Imaging System & $R L-E R O 6$ & $06 / 00$ & $07 / 00(A)^{\prime \prime}$ \\
\hline $\begin{array}{l}\text { Liquid-Leve/ Detection Technology } \\
\text { (Thermography and/or Ultrasonici) }\end{array}$ & $R L-E R 05$ & $09 / 00$ & ' \\
\hline $\begin{array}{l}\text { In Situ Object Characterization Survey (ISOCS) } \\
\text { System }\end{array}$ & $R L-E R O G$ & $09 / 00$ & $07 / 00(A)^{\prime \prime}$ \\
\hline Remote Drain Line Characterization Technology & $R L-E R 05$ & "I & $08 / 00(A)$ \\
\hline Overview Video System (OVS) & $R L \cdot E R 05$ & 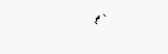 & $01 / 00(A)$ \\
\hline Passive Soil Vapor Extraction (SVE) & $R L \cdot E R O B$ & ' & $10 / 99(A)$ \\
\hline Wireline Cone Penetrometer & $R L-E R O I$ & & $08 / 00(A)$ \\
\hline \multicolumn{4}{|c|}{ 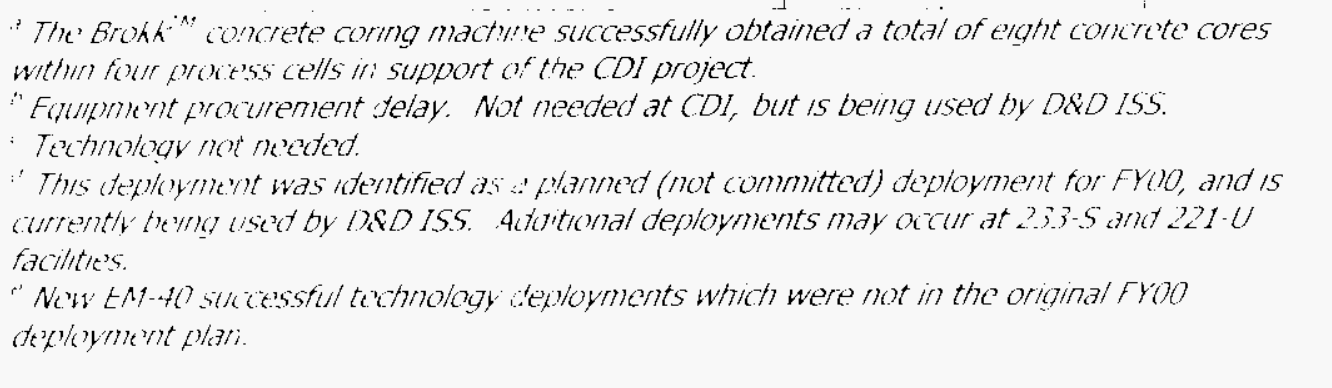 } \\
\hline
\end{tabular}

STRETCH AND SUPERSTRETCH GOALS: PMES

Nont atentific't at thrs time? 


\title{
ENVIRONMENTAL MANAGEMENT PERFORMANCE REPORT ENVIRONMENTAL RESTORATION NOVEMBER 2000
}

PROJECT STATUS (COST/SCHEDULE/MAJOR BASELINE CHANGE): PMKS

- Schedule:

\begin{tabular}{|c|r|r|r|}
\hline \multirow{2}{*}{ Program Management \& Support } & \multicolumn{1}{c|}{ BCWS } & \multicolumn{1}{c|}{ BCWP } & Variance \\
\cline { 2 - 4 } & \multicolumn{1}{c|}{$\mathbf{\$ K}$} & $\mathbf{\$ K}$ & $\mathbf{\$ K}$ \\
\hline ER10 ERC Program Management \& Support & 28,52 & 26,775 & $-1,747$ \\
\hline ER1O RL Program Management \& Support & 5,835 & $\mathbf{4 , 5 3 , 3}$ & $-1,282$ \\
\hline TOTAL PM\&S & $\mathbf{3 4 , 3 5 7}$ & $\mathbf{3 1 , 3 2 8}$ & $\mathbf{- 3 , 0 2 9}$ \\
\hline
\end{tabular}

PBS-ER1O - Program Management and Support

Schedule Varlance $=\mathbf{- \$ 3 0 2 9 K} ; \mathbf{- 8 . 8 \%}$ [Last Month: $-\$ 1430 \mathrm{k} ;-5.3 \%$ ]

\begin{abstract}
Cause: ERC performance fee on base and Superstretch work for F Reactor 15s, two remedial action sites, and well decommissioning will bo paid uphl planned complytion in FYO1.
\end{abstract}

Resolution: Performance fee will be carried over to fyol relative to work schedulted. Cause: Late billing on RL site-wide assessments.

Resolution: RL is discussing billing/timing with other site contractors government agencies.

PROJECT STATUS (COST/SCHEDULE/MAJOR BASELINE CHANGE) continued: PMRS - Cost:

\begin{tabular}{|c|r|r|r|}
\hline \multirow{2}{*}{ Program Management \& Support } & \multicolumn{1}{c|}{ BCWP } & \multicolumn{1}{c|}{ ACWP } & Variance \\
\cline { 2 - 4 } & \multicolumn{1}{|c|}{$\mathbf{\$ K}$} & $\mathbf{\$ K}$ & $\mathbf{\$ K}$ \\
\hline ER10 ERC Program Management \& Support & $26,7,5$ & 26,248 & 5,77 \\
\hline ER10 RL Program Management \& Support & 4,553 & 4,553 & 0 \\
\hline TOTAL PM\&S & $\mathbf{3 1 , 3 2 8}$ & 30,801 & 527 \\
\hline
\end{tabular}

PBS-ERIO - Program Management and Support

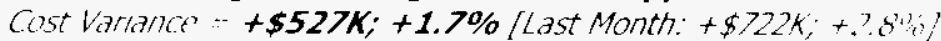

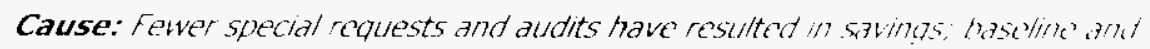
strategic planning, staff savings.

Resolution: Savings were used to perform other renterthalion with.

REGULATORY ISSUES: PMES

None identified at this timle?

EXTERNAL ISSUES (i.e. HAB, Congress, etc.): PM\&S

None identitied at this timn? 


\section{ENVIRONMENTAL. MANAGEMENT PERFORMANCE REPORT ENVIRONMENTAL RESTORATION \\ NOVEMBER 2000}

DOE-RL \& HQ ISSUES/REQUESTS (not covered elsewhere): PM\&S

None identified at this time.

\section{INTEGRATION ACTIVITIES: PMRS}

Following is a summiary of significant integration activities identificd during froo:

"Strength through Science" Exhibit: Bechtel Hanford, Inc. led the effort with assistance from Fluor and PNNL in the preparation, assembling and shipping of posters and handout materials for the DOE-RL Capital Hili axhibit titled "Strength through Science". The exhibit was attended by several Congressmen, sinators and thesr staff and was judged as one of the best among the DOE Complet.

Planning \& Controls: Represented ER at the Hanford Site Change Control Performance Improvement Ttam (PIT) meeting. The February meeting included preparation of matcrial and presentation of several ER BCFS to the PIT members. ERC's process for administering the Stretch and Superstretch performance incentives was also discussed. The PIT consists of RL and thanford coritractor representatives: 


\section{Richland Operations Office Environmental Restoration \\ Environmental Management Performance Report}

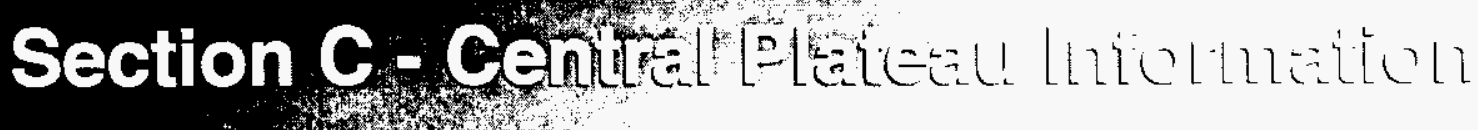

November 2000

- Groundwater / Vadose Zone Integration Project

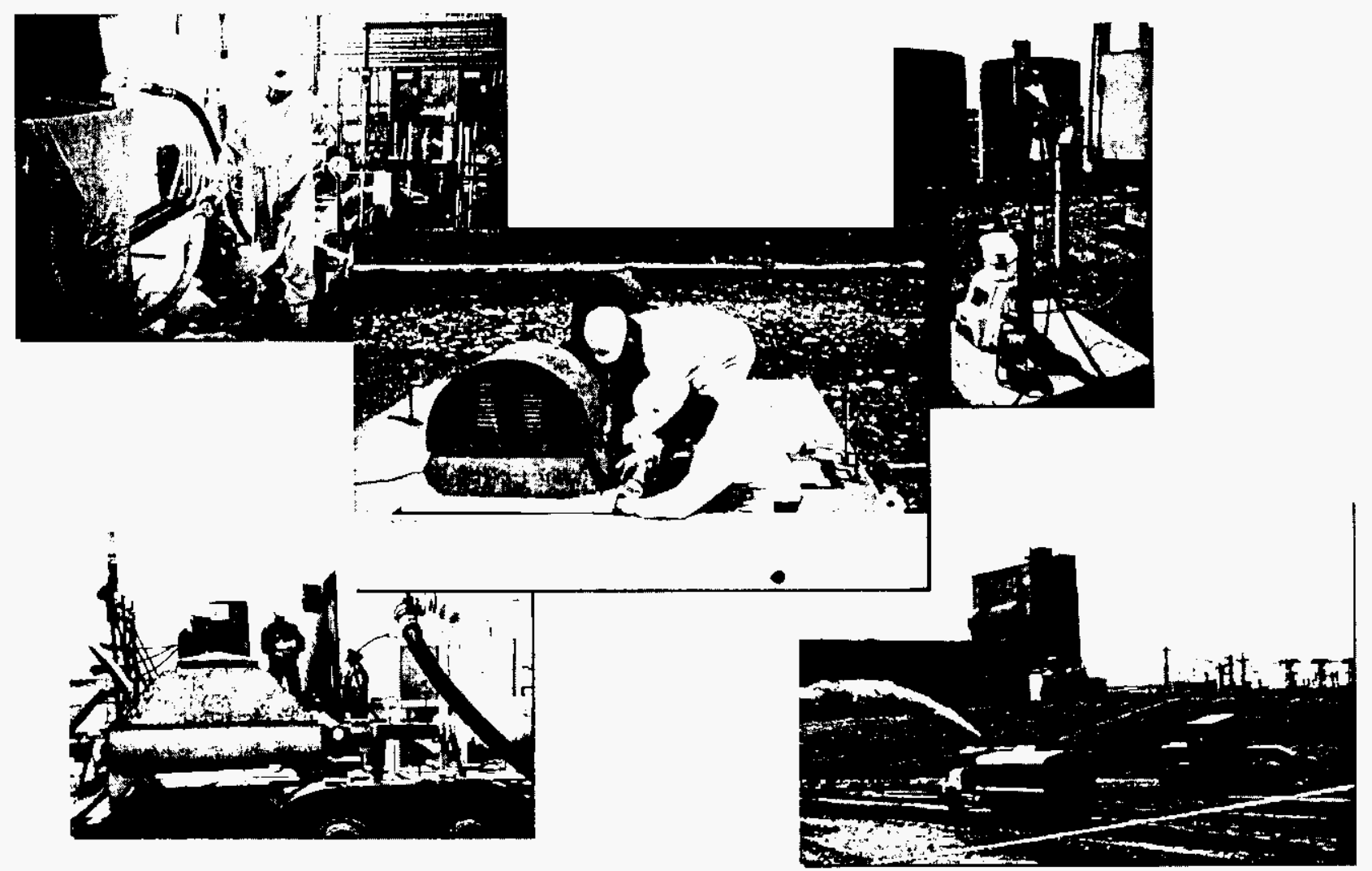

- Surveillance / Maintenance \& Transition Projects

Focused on Progress...

Focused on Outcomes!

Department of Energy

Richland Operations Office 


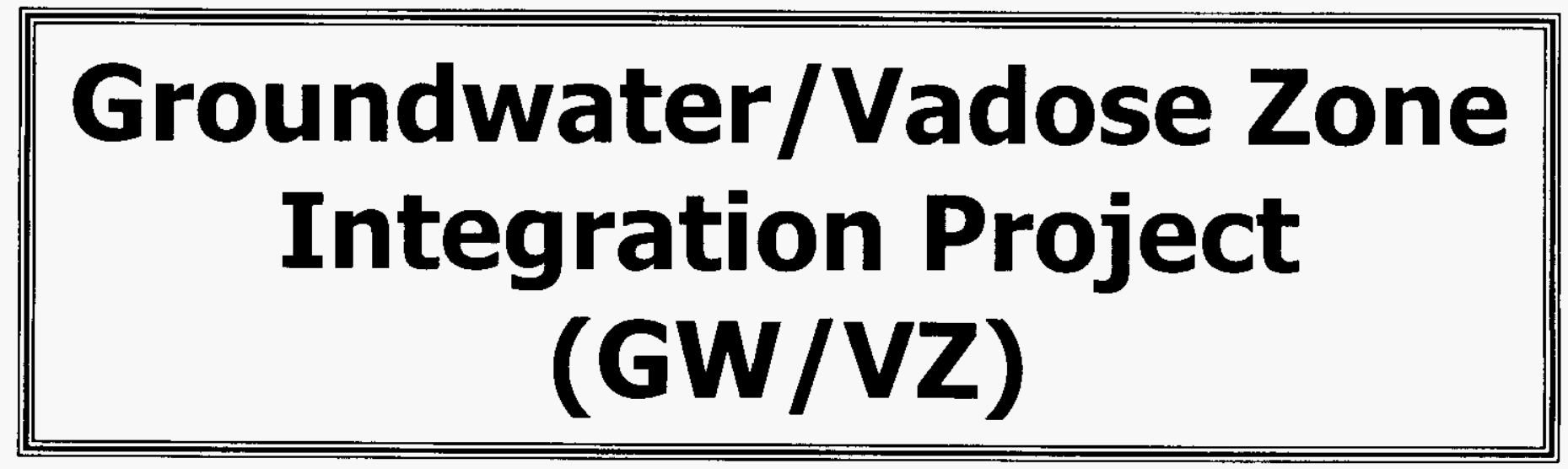




\section{ENVIRONMENTAL MANAGEMENT PERFORMANCE REPORT ENVIRONMENTAL RESTORATION NOVEMBER 2000}

\section{SECTION C - TRANSITIONING THE CENTRAL PLATEAU}

\section{Financial / Performance Measures data as of month-end September.}

All other data as of October 26, 2000 (unless otherwise noted).

\section{Groundwater/Vadose Zone Integration Project(GW/VZ);}

\section{ACCOMPLISHMENTS: $G W V Z$}

\section{FYOO SUMMARY}

Following is a summary of significant Gioundwater/ Vadose Zone Integration Project accomplishments achieved during tyol. The FYoO accomplishments are grouped into three categories: momentum, progress, and completion/removal. The Project's top five accomplishments are underlined for tasy recognition.

Momentum: (how Hanford cleanluf has been "sped up")

\section{Groundwater Management:}

Received regulator approval for the ISFM Project ROD Amendment. The ISRM tectunology involves injecting a chemical (sodiumi aithionite) into all aquifer to create a chemically-altered treatment zone. Studies completed to date indicate that, when the chromium-contaminated groundwater passes through the permeable chemical zone (barrier), chromium is transformed into a harmless chemical and is immobilized.

Progress: ("things" achieved in terms: of amounts or percentages)

\section{Groundwater/Vadose Zone:}

Completed techn!cal and management reviews of the SAC resulting validation of the approach being taken to develop the SAC and in Integration. Project Expert Panel support for the SAC activity. The SAC Rev. O software development and testing were also completed. The SAC is being designed to provide a cumulative assessment of the impacts and risks associated with Hanford Site contaminants.

Completed field activities at the Vadose Zonc Transport Field Study site and commenced data interpretation. The main objectives of this field study are to focus on the underaround tank leak issues, improve vadose nonitoning capabilities, identify key transport processe's, and provide data for model verification.

ISSiled the S\&I Roadmat, Rev. 1 (sat/sying a FYOO HQ Mandagement Conmitment Milestoni). This document links science to address the' contaminant concerns telating to Inventory, Vatost. sone, Groundwater, Columbia River, and Risk technical elements.

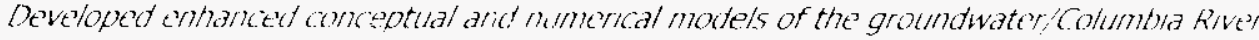
interface:

Completed databast deveropment "' slippont characterleation of systems hy defining issin's management, and tiatures, events, cint processe's protocols.

Hosted me'tings with the' integration: frolect Expert Panel and the National Acartemy of Sconces: Particuated in meetings with the Oregon Hanford Waste Board, Oregon office of

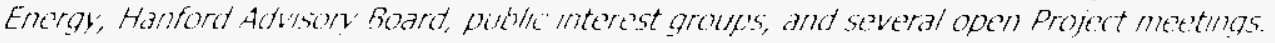

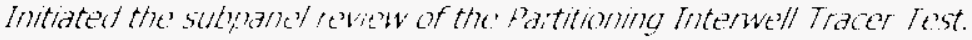




\section{ENVIRONMENTAL MANAGEMENT PERFORMANCE REPORT ENVIRONMENTAL RESTORATION NOVEMBER 2000}

ACCOMPLISHMENTS continued: $G W / V Z$ Groundwater Management:

Completed FYOO ISRM Project activities including awarding the contract, constructing an? evaporation pond, installing 16 wells, and initiating chemical barrier injections and withdrawals in 10 wells (satisfying a FYOO HQ Management Commitment Milestone). The subterrancan chemical barrier is 31 meters (100 feet) deep and extends 198 meters (650 fect) between the DR Reactor and the Columbia River. By 2002, the barrier is expected to reach its final length of 702 meters $(2,300$ feet $)$.

Completed Phase I for the 618-11 Burial Ground elevated tritum investigation. Phase' I involved sampling and analysis of 22 wells for tritium and other constituents. Results indicated two areas of high concentrations of helium, which is a natural byproduct of the radioactive? decay process of tritium. Phase II of the tritium investigation will include obtaining additional soil gas samples and two groundwater samples. The results of the additional tests will help determine if the helium is coming from a tritium source buried in the waste site or from tritum contamination in the ground water. The 618-11 Burial Ground is located adjacent to a commercial nuclear reactor complex and is about 6 kilometers (3.5 miles) from the columbla River.

Completed routine well maintenance and groundwater monitoring activities. At the end of FYO0, maintenance had been completed on 179 wells, 27 less than the 206 planned wells (planned carryover).

Operated all five groundwater pump and treat systems above the planned $90 \%$ avaliability during FYOO (97\% actual; $90 \%$ planned). The pump and treat systems remove contaminants (carbon tetrachloride, strontium, and chromium) from the groundwater and mitigate further migration to the Columbia River. Approximately 1.1 billion liters of groundwater were processed during FYOO; over 4.3 billion liters of groundwater have been processed to date?

Completion/Removal: ("what's done and what's gone")

Groundwater/Vadose Zone:

Completed the Semi-Annual Groundwater/Vadose Zone Report to Congress (satisfying a FroO HQ Management Commitment Milcstone).

\section{Groundwater Management:}

Completed installation of a total of 13 Resource Conservation and Recovery ACt (RCRA) groundwater wells. The first eight RCRA wells were installed in February which satisfited Til Party Agreement Milestone M-24-00K. An additional five RCRA wells were installed through September which satisified Tri-Party Agreement Milestone M-24-46, due December 31. ?000 (15 weeks ahead of scheduk). Timely installation of these five walls also supported (th:M HILL Hanford Group ( $\mathrm{CHG}$ ) in meeting one of their FYOO performance incentives.

\section{Area Assessments:}

Completed Froo field characterization activities for the $200-\mathrm{CW}-1$ Gable Mountain $B$ Pond Cooling Water Operable Unt . This included 12 test pits and onc borehole. Significant cost savings resulted from utiliang prior-year lessons learned on this project.

Completed Draft A 200 Ch'-5 Operable Unit Remedial Investigation/Feasibility Study IVork Plan (Satisfying Tri-Party Agrcement Milestone M-13-22) and Drafi A 200-7W-1 and 200-7n-2 Operable Unit RI/FS Work Plan (satisfying Tri-Party Agreement Milestones M. 13 -23 and M-1.324). A portion of the FYOO savings from other ER work was allocated to allow full sival'. 't? Area assessment wark to commence in FYO1. 


\section{ENVIRONMENTAL MANAGEMENT PERFORMANCE REPORT ENVIRONMENTAL RESTORATION \\ NOVEMBER 2000}

\section{SAFETY/ISMS/CONDUCT OF OPERATIONS: $G W / V Z$}

See Executive Sumimary.

BREAKTHROUGHS/OPPORTUNITIES FOR IMPROVEMENT: $G W / V Z$

None identified at this time.

\section{LONG-TERM (6 MONTHS PLUS) IMPORTANT ITEMS: $G W / V Z$}

Following is a summary of significant leng-term important items identified during Fröo.

Key ISRM FY 2000 Activities: Initiated ISRM tectinology.

Fy 2001 Activities: (Planned Activities)

Activities: Drill and install twenty-four ISRM Barrier Wells. Utilize all wells for ISRM Barrier emplacement.

(Approximately 240 meters of additional ISRM Barrier length to be constructed in FY 2001.)

Drill and install four ISRM compliance wells.

Fy 2002 Activities: (Planned Activitiec)

Activities: Drill and install twenty-four ISRM Barrier Wells. Utilize all remlainnng wells for ISRM Barrier emplacernent.

(Approximately 240 meters of additional ISRM Barrier length to be constructed in FY 2002.)

Demobilize evaporation pond (FY 2(10? or FY 2003 Activity).

MAJOR COMMITMENTS (FISCAL YEAR PLUS 6 MONTHS): $G W / V Z$

- DOE secretarial:

Transmit Update of the Vadose Zone Science and Techrrology Roadmap (PBS VZO1) due April 30.

Status: Complete. Draft was transmitted to RL on April 28.

Install Wells and Initiate Invection of the Barrier for Phase I of the In Situ Reduction Oxidation (REDOX) Groundwater Remediation (PBS EROB) due September 30.

Status: Complete.

- 16-well installitions we't? completed on April 24.

- The evaporation pond was ready on lufy 31 for use in managing extraction wastes.

- Well injections began on August 1, as scheduled. Teln wells were chemically injected as of the end of September.

- Scope for Phase II inclutes installation of 28 injection wells and 4 complance monituring wel/s.

- Well planning activities including preparation of Description of Work and initiation of site walk dowiss, are undenway.

- A chemical injection into one well is scheduled for the end of October.

Complete the Semi-Annual Groundwittor, Vadose Lone Report (December 1999 - March 2000) (PBS VZO1) due May 31.

Status: Complete? Fingal docment was transmitted to R'L on May 31.

- DOE EM Performance Agreement:

Nolle identified at this timle. 


\section{ENVIRONMENTAL MANAGEMENT PERFORMANCE REPORT ENVIRONMENTAL RESTORATION NOVEMBER 2000}

MAJOR COMMITMENTS (FISCAL YEAR PLUS 6 MONTHS) continued: $G W / V Z$

- TPA Milestones:

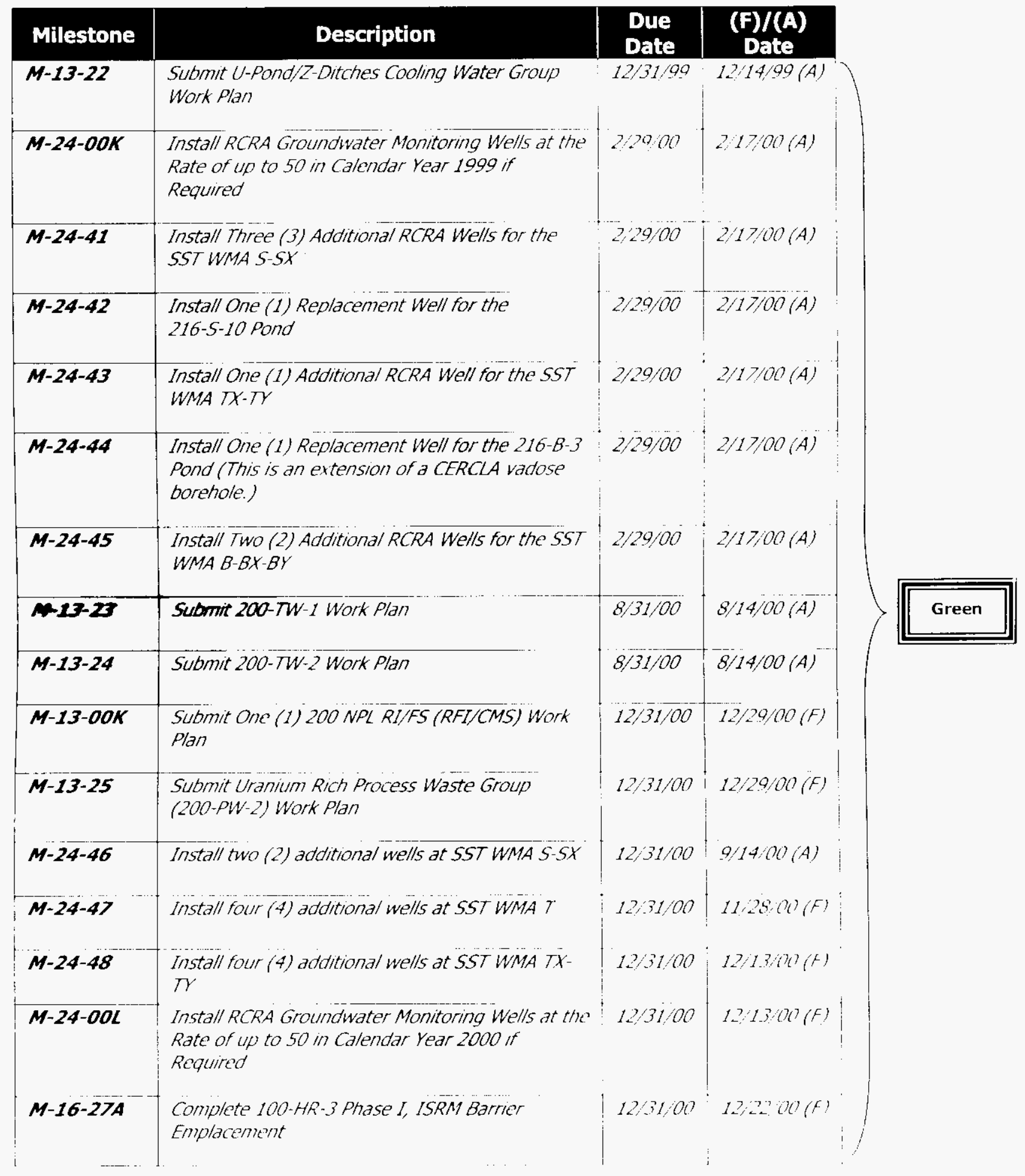

- DNFSB Commitment:

None identified at this time. 


\section{ENVIRONMENTAL. MANAGEMENT PERFORMANCE REPORT ENVIRONMENTAL RESTORATION \\ NOVEMBER 2000}

PERFORMANCE OB.JECTIVES: $G W / V Z$

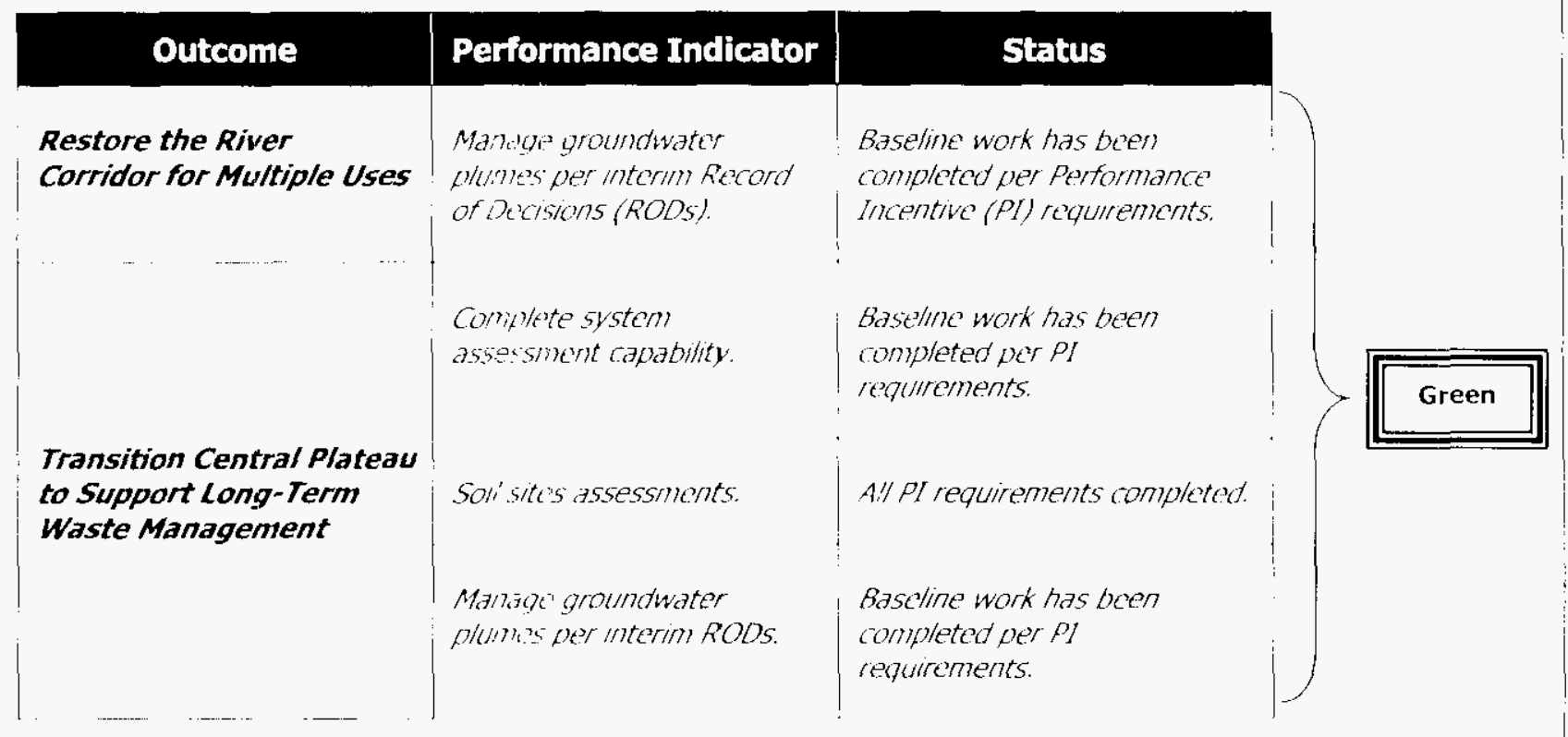

PERFORMANCE MEASURES: $G W / V Z$

None planned in FY 2000 .

STRETCH AND SUPERSTRETCH GOALS: $G W / V Z$

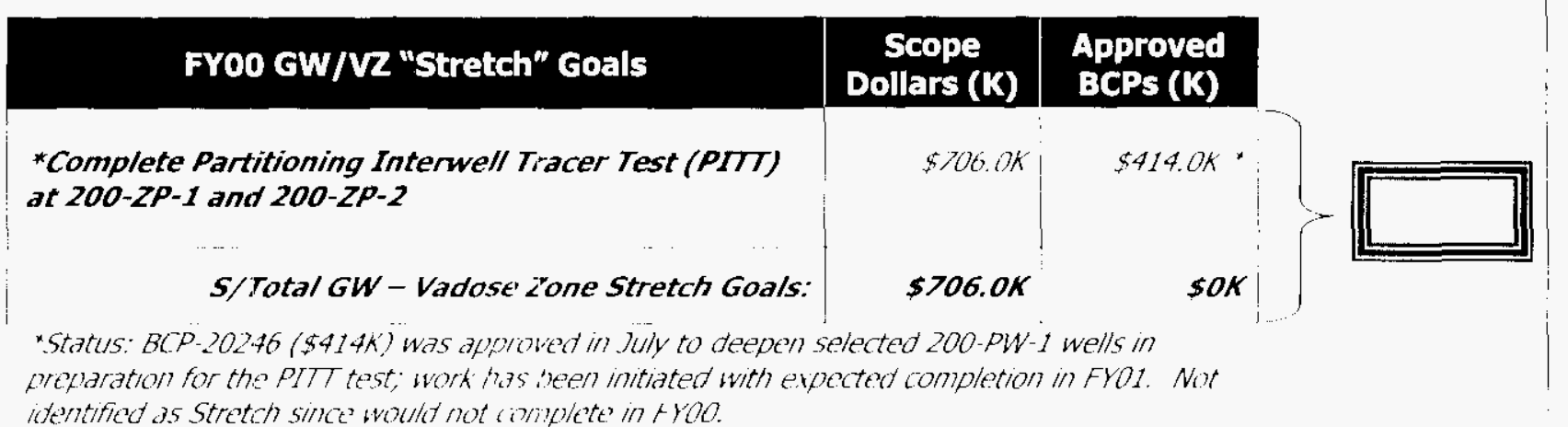




\section{ENVIRONMENTAL MANAGEMENT PERFORMANCE REPORT ENVIRONMENTAL RESTORATION NOVEMBER 2000}

STRETCH AND SUPERSTRETCH GOALS continued: $G W / V Z$

\section{FY00 GW/VZ "Superstretch" Goals}

Provide Permanent Solution for Hanford Groundwater Plumes

Complete Remediation of 60 Sq. Mi. of Hanford Site:

(1) *Decommission $4 \mathrm{we} / \mathrm{s}$

(2) *Evaluate 300 wells and decommission up to 90

S/Total GW - Vadose Zone Superstretch Goals:

\section{Scope Approved Dollars (K) $\quad$ BCPs (K)}

$$
\begin{array}{r|r}
\$ 750.0 K & \$ 0.0 K \\
& \\
\$ 450.0 K & \$ 104.0 K \\
\$ 900.0 K & \$ 1478.0 K \\
\$ 2,100.0 K & \$ 1582.0 K
\end{array}
$$

* Status: Efficiencies identified. BCPS 20248 and 20185 were endorsed by DOE-RL ASSIstant Manager for Environmental Restoration \& Waste Management (AMEW) on Auqust 10 to

\begin{tabular}{|c|c|c|c|c|}
\hline \multirow{2}{*}{ GW/VZ Integration Project } & BCWS & BCWP & Variance & \\
\hline & $\$ \mathbf{K}$ & $\$ \mathbf{K}$ & $\$ \mathbf{K}$ & \\
\hline ERO2 200 Area Remedial Actions & 3,592 & 3,497 & -95 & \\
\hline ER08 Groundwater Management & 25,770 & 21,335 & $-4,4,35$ & Green \\
\hline VZO1 Groundwater/Vadose Zone & 11,276 & 10,359 & -917 & \\
\hline rotAL Groundwater & 40,638 & 35,191 & $-5,447$ & \\
\hline
\end{tabular}
administratively verify and decommission wells within the Columbia River Corridor.

**Efficiencies applied to Superstretch projects in Remedial Action and Decommissioning Projects.

PROJECT STATUS (COST/SCHEDULE/MAJOR BASELINE CHANGE: GW/VZ

- schedule:

PBS-EROZ - 200 Area Remedial Action (Assessment)

Schedule Variance $=-\$ 95 K ;-2.6 \%$ [Last Month: $-\$ 44 K ;-1.3 \%$ ]

Cause: Removal of the irrigation system for the Hanford Prototype Barrier was deferred pending an evaluation of excessing-in-place scenario.

Resolution: The evaluation is complete. The systenl will be removed. Workscope will be carried over to FYol.

PBS-EROS - Groundwater Management

schedule Variance $=-\$ 4435 \% ;-17.2 \%$ [Last Month: $-\$ 1853 k ;-9.8 \%$ ]

Cause: Efficiencles allowed well installation and decommissioning superstretch workscope to be. initiated in FYOO but major work activites w/ll occull in FYO1.

Resolution: None requred. Well decommissioning is unterwab. Planned carryover. 


\section{ENVIRONMENTAL MANAGEMENT PERFORMANCE REPORT ENVIRONMENTAL RESTORATION \\ NOVEMBER 2000}

PROJECT STATUS (COST/SCHEDULE/MAJOR BASELINE CHANGE) continued: $G W / V Z$

Cause: 200-ZP ? PITT well decpening work scope was approved in FYoO with the understanding that most of the work would be completed in Fyo1.

Resolution: None; plannew' arryover.

Cause: Groundwater monituring activitie's conlisisting of sample collection, analysis, interpretation and reporting, aind hydrologic assessment are behind schedule due to resource limitations.

Resolution: Sampling teams working overtinte when possible. Workscope will be carried over into FYot.

PBS-VZO1 - Groundwater/Vadose Zone

Schedule Variance $=-\$ 917 K ;-8.1 \%$ [Last Month: $-\$ 942 K ;-9.1 \%$ ]

Cause: Field investigation at representative sites behind schedule due to delayed distribution of samples to tha iab and receipt of sample analysis.

Resolution: Schedule is riot recoverable this fiscal year. RPp Field Investigation Report milestone extended, broyect in sync with RPP schedule; carryover initiated.

Cause: Technical resource, wivilability (formation of the core team) delayed Characterization of Systemis initiotion.

Resolution: Workscope will the carried over to FYo1.

- Cost:

\begin{tabular}{|l|r|r|r|}
\hline \multicolumn{1}{|c|}{ GW/VZ Integration Project } & \multicolumn{1}{c|}{ BCWP } & \multicolumn{1}{c|}{ ACWP } & Variance \\
\cline { 2 - 4 } & \multicolumn{1}{c|}{$\mathbf{\$ K}$} & $\mathbf{1}$ & $\mathbf{\$ K}$ \\
\hline ER02 200 Area Remedial ACtions & 3,497 & 2,456 & 1,041 \\
\hline ER08 Groundwater Management & 21,335 & 21,058 & 277 \\
\hline VZO1 Groundwater/Vadose Zone & 10,359 & 10,179 & 180 \\
\hline TOTAL Groundwater & $\mathbf{3 5 , 1 9 1}$ & $\mathbf{3 3 , 6 9 3}$ & $\mathbf{1 , 4 9 8}$ \\
\hline
\end{tabular}

PBS-ERO2 - 200 Area Remedial Action(Assessment)

Cust Variance $=+\mathbf{\$} 1041 \mathrm{~K} ;+\mathbf{2 9 . 8 \%}$ [last Month: $+\$ 1133 \mathrm{~K} ;+32.6 \%$ ]

Cause: Efficiencles learne it in brior work were applied to Gable Mountain and B Pond test pit irenching, resulting "il savings. Borehole drilling was combined with RCRA drilling resulting in cost sawngs.

Resolution: Savings we'te wse'd to perform ather remediation work.

PBS-EROS - Groundwater Management

Cost Variance $=+\$ 277 K ;+1.3 \%$ [last Month: $+\$ 597 \% ;+3.1 \%$ ]

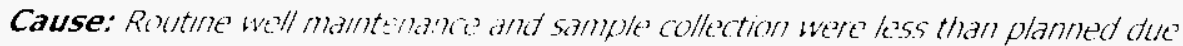

to unresolved waste issues.

Resolution: Sav'ngs we?te? used to pertom ather remediation work 


\title{
ENVIRONMENTAL MANAGEMENT PERFORMANCE REPORT ENVIRONMENTAL RESTORATION \\ NOVEMBER 2000
}

\author{
PROJECT STATUS (COST/SCHEDULE/MAJOR BASELINE CHANGE) continued: $G W / V Z$ \\ PBS-VZO1 - Groundwater/Vadose Zone \\ Cost Variance $=\mathbf{+ \$ 1 8 0 K ;}+\mathbf{1 . 7 \%}$ [Last Month: $+\$ 484 K_{i}+5.1 \%$ ]
}

Cause: Science \& Technology and Characterization of Systems used fewer resources than planned; Expert Panel meeting completed for less than planned.

Resolution: Savings were used to perform other remediation work.

REGULATORY ISSUES: $G W / Z Z$

A number of significant issues were identified and resolved during fyoO. Those remaining at fiscal year end include:

Monitoring Wells: Tritium investigation is being conducted near the 618-11 Burial Ground.

Status: The results from the 618-11 soil gas investigation have been evaluated, compiled, and mapped. The helium ratios indicate important tritum sources along the eastern half of the northern boundary and the northern third of the eastern boundary. The ratios do not indicate important tritum sources a/ong the western or southern boundaries of the burial ground.

Based on the soil gas helium ratios, additional sampling and analyses tasks have been mitiated to further define the nature and extent of the tritium contamination near the 618-11 burial ground. These tasks include:

- Groundwater grabs from boreholes C-32-64 and C-32-65 to assess tritium levels in the groundwater and verify the correlation between groundwater concentrations and the helium ratios measured

- Additional soll gas sampling (helium analysis) along the northern boundary to assess the potential extent of contamination based on helium ratio results

- soil moisture sampling (tritium analysis) along the eastern and northern boundaries to assess the extent of contamination in the vadose zone

- variable depth soil gas sampling (helium analysis) at the northern boundary peak helium ratio locations to establish the tritium source (i.e., groundwater or vadose)

Borehole C-32-6 (about midway along the northern boundary of the 618-11 Burial Ground) was completed to groundwater and a groundwater grab sample was collected on October 9. The initial results from the C-32-64 groundwater grab indicated tritium levels less than 30,000 pcifliter. The final results for this borehole are expected by November 1.

Borehole C-32-65 (in the Energy Northwest parking lot, east of the 618-11 Burlal Ground) was completed to groundwater and a groundwater grab sample was collected on October 13. The groundwater sample has bezen submitted for laboratury analysis and the initial results are expected in early November.

The placement of additional soil gas sampling ports, soll gas sampling, and soil moisture sampling are scheduled. 


\title{
ENVIRONMENTAL MANAGEMENT PERFORMANCE REPORT ENVIRONMENTAL RESTORATION NOVEMBER 2000
}

\section{REGULATORY ISSUES continued: $G W V V Z$}

200-ZP-1/200-ZP-2: Need for enhariced haracteriation, chloance renioval efficiency, and Dense' Non-Aqueous Phase Liquid (DNA,Pl) Investigation.

\begin{abstract}
Status: Project personnel mei with EPA (Doug Sherwood), to discuss the need to restart $2 P-2$ pending complition of the cost estimatc to perform the Partitioning Intenwell Tracel Test (PITI) for DNAPL Investigation. Decision was made to procecd with the PITT test in lieu of - estarting ZP-2 this fiscal ycar. Drilling will proceed to deepen three wells in support of the PIT and to enhance the current vapor extraction system. A preliminciry cost estimate and proposial submitted by a potential contracior is currently being re'viewed by a subpanel of the GW/VZ Integration Project's Expert Panel. Evaluation is to be completed by the end of October. A prediniriary cost estimate wa's breprared by BHI for the cost to provide support to the potential contractor.
\end{abstract}

200 Area Remedial Investigation/seasibility Study: Approximately 800 contaminated soil sites in the 200 Area, which have bieen grouped into 23 process-based operable units, are to be characterized by 2008 and renle giated by 2018. \$5M to \$6M per year are required to meet Tri-Party Agreement milestones a butgetary position toward assessment and cleanup of the 200 Area liquid waste' sites is ne'eded for the long term. The regulator position is to submit Tri Party Agreenient change package's for tach operable unit work plan, to support enforceability in completing remedial investigations through the ROD, based on existing TriParty Agrecment milestones.

Status: Tri-Party Agreement hange packages for the 200-CW-1, 200-CW-5, and 200-CS-1 Operable Units containing RI/FS interim milestones were approved on August 23. In addition, RL is currently working on ways to revise the existing longterm strategy for prioritizing the 200 Arca assessment and remediation activities in conjunction with other site cleanup decisions. RL is also seeking to justify and identify additional funds for characterization. RL is pursuing $\$ 2.5 \mathrm{M}$ additional authorization from other RL funding sources. and the ERC has identified $\$ 2.0 \mathrm{M}$ (from FYOO efficiencies) for FYO1 workscope. The ERC team, in conjunction with RL management, will meet with the regulators to discuss a proposed strategy for initiation of this work.

\section{WASTE MANAGEMENT ISSUES:}

Biosite Notice of Correction: On Mav 31, a Notice of Correction (NOC) letter was received by RL from Ecology. This NOC detailer the violations and corrections regarding the shipments of mixed solid wastes that contacted aroundwater that contains listed waste (Fyol and Fro3), and the drums of $M-24$ drilling waste at the Biosite.

Status: RL/BHI response was issued on June 26. Re'quirements include (1) Issue formal notification to Rabanco and City of Richland Landfills (completed), and (2) De'signation and shipment or Eiosite. Waste (135 drums) was completed in september.

200-CW-1 IDW' Waste Disposal at ERDF: A reculest for a contaned-ln tetermination was approved for the $200-\mathrm{CW}$-! investiganon derived waste (IDW) by Ecology. Waste had to be

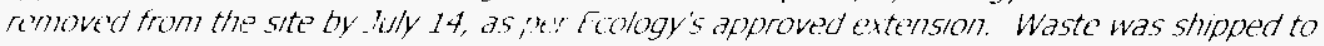
ERLE, with approval from EPA. Disphesil into ERDF was delayed pending either approval of the zoO CW I work plan by Ecology or winlmatur' of the' change package.

Status: A TPA thange packizen' was sighed on August ?3. There were 46 drums on a truck at ERDF. ApDroval was lieciver from both regulatory agencies to dispose of 38 arums with a contained in deternmation. Ecology has approved the remalning $\&$ arums tor disposain Octobt. 


\title{
ENVIRONMENTAL MANAGEMENT PERFORMANCE REPORT ENVIRONMENTAL RESTORATION \\ NOVEMBER 2000
}

\begin{abstract}
REGULATORY ISSUES continued: $G W / V Z$
- Purgewater Secondary Waste Management: There is a discrepancy in the interpretation of the Purgewater Strategy applicability. Direction was given by Rt to become compliant with all land disposal restriction (LDR) ricuirements.

Status: An interim phase was initiated, and a screening was completed for thi' potential listed waste codes to be applied. Activities on Site will be conducted as planned, with a conservative application of the listed waste codes to the secondary wastes. A long-term resolution has also been accepted by RL, to conduct a Listed Waste Applicability Assessment to minimize the listed waste codes to be applied on this waste stream. Meetings with the regulators to resolve pending issues are being planned to take place by mid-November 2000.
\end{abstract}

EXTERNAL ISSUES (i.e. HAB, Congress, etc.): $G W / Z$

None identified at this time.

DOE-RL \& HQ ISSUES/REQUESTS (not covered elsewhere): GW/VZ None identified at this time.

INTEGRATION ACTIVITIES: $G W / V Z$

Following is a summary of significant integration activities identified during FyoO:

CHG: Five RCRA well installations were completed prior to September 30 in Support of TPA Milestone M-24-00L (due December 31, 2000). This effort supported CHG in meeting one of their FYOG performance incentives. 


\section{ENVIRONMENTAL MANAGEMENT PERFORMANCE REPORT}

ENVIRONMENTAL RESTORATION

NOVEMBER 2000

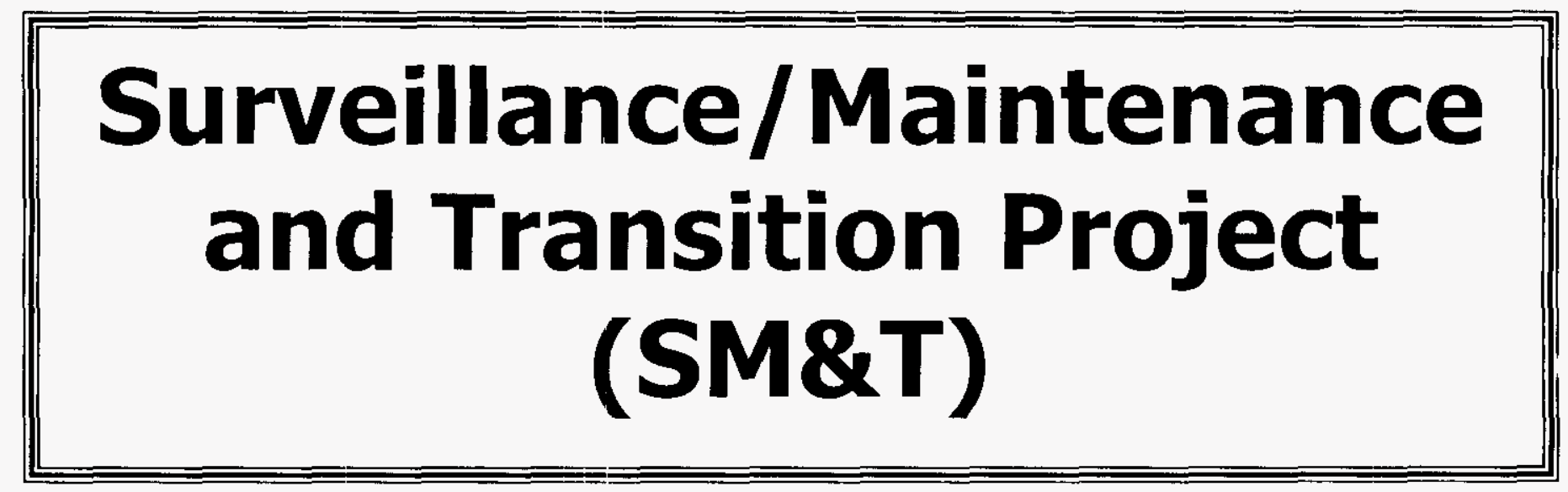




\section{ENVIRONMENTAL MANAGEMENT PERFORMANCE REPORT ENVIRONMENTAL RESTORATION NOVEMBER 2000}

\section{SECTION C - TRANSITIONING THE CENTRAL PLATEAU}

Financial / Performance Measures data as of month-end September. All other data as of October 26, 2000 (unless otherwise noted). Surveillance/Maintenance \& Transition Project (SM\&T):

\section{ACCOMPLISHMENTS: $S M \& T$}

FYOO SUMMARY

Following is a summary of significant Surveillance/Maintenance and Transition Project accomplishments achieved during FYOO. The FYOO accomplishments are grouped into three categories: momentum, progress, and completion/removal. The Project's top five accomplishments are underlined for easy recognition.

Momentum: (how Manford cleanup has been "sped up")

Completed the CDI drain header characterization in U Plant (221-U Bulding) utilizing a robotic crawler in Auqust. The robot traveled the equivalent of nearly three football fields to visually inspect the 24-inch diameter drain line for structural integrity, to obtain radiation readings, and to collect samples of contaminated materials within the line.

Completed accessing 38 process cel/s in U Plant in support of CDI in August. Data gathered from these cells will be used to determine the final disposition of the five defunct chemical processing facilities (canyons) on the Hanford Site.

Completed successful concrete core sampling in four process cells in U Plant in September to determine chemical, radiological, and physical characterization (depth of liquid penctration) conditions of the concrete floors.

Progress: ("things" achieved in terms of amounts or percentages)

Completed plutonium loadout hood stabilization activities in the REDOX facility.

Initiated S\&M activities in the B Plant interior after FH completed required corrective actions to the building ventilation system. There was no evidence of any degradation due to the ventilation system being inoperable for more than ten months. No entry was allowed into the facility while the ventilation system was being repaired.

Completed sample collection and stabilization of the KE/KW acid tanks, and issued final report. Completed annual surveillance and housckeeping activities at D, H, KE and KW Reactors.

Completed the REDOX railroad cut interim stabilization.

Completed backfill/downpost of all the outdoor contamination arcas around REDOX.

Completed the RARA Annual Report, spring revegetation activities, and fall herbicide spyaying. Completed bare ground herbicide applications.

Completion/Removal: ("what's done and what's gone")

Completed deactivation of the old $100 \mathrm{~N}$ Area water plant and completed construction and startup of the new replacement water plant. 


\section{ENVIRONMENTAL MANAGEMENT PERFORMANCE REPORT ENVIRONMENTAL RESTORATION NOVEMBER 2000}

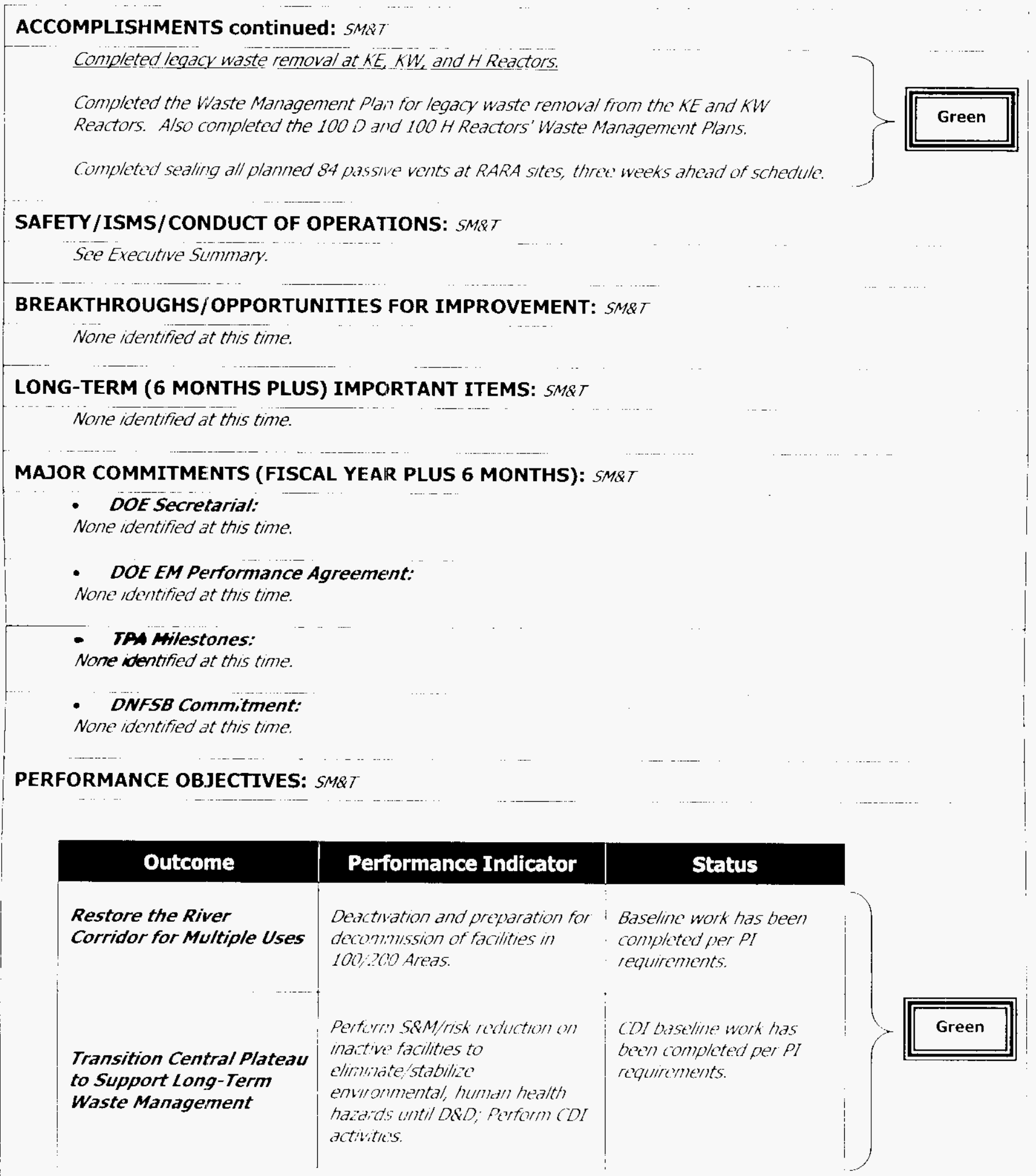




\section{ENVIRONMENTAL MANAGEMENT PERFORMANCE REPORT ENVIRONMENTAL RESTORATION NOVEMBER 2000}

PERFORMANCE MEASURES: SM\&T

None planned in FY 2000

STRETCH AND SUPERSTRETCH GOALS: SM\&T

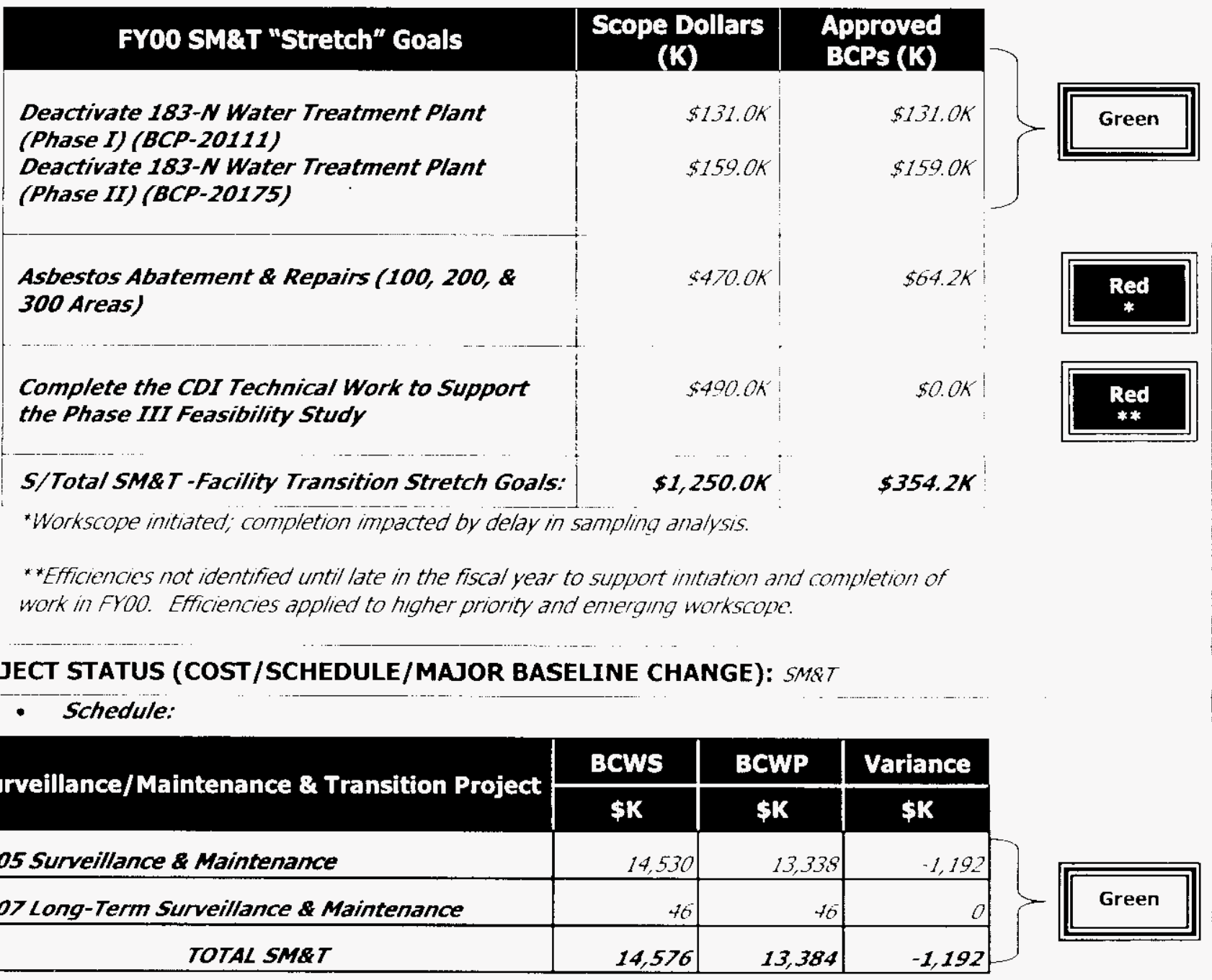

PBS-ERO5 - Surveillance and Maintenance

Schedule Variance $=-\$ 1192 K ;-8.2 \%$ [Last Month: $-\$ 79.3$; $0.1 \%$ ]

Cause: Completion of the B Reactor hazards mitigation (including roof repalr) was approver in FYOO with work planned for FYOI.

Resolution: None; planned carryover.

Cause: Major repalrs on REDOX compressor and exhaust fall delaved pernding evaluation of work priorities.

Resolution: The immediate need for repairs/maintenancis is benlin assessed. 


\section{ENVIRONMENTAL MANAGEMENT PERFORMANCE REPORT ENVIRONMENTAL RESTORATION NOVEMBER 2000}

PROJECT STATUS (COST/SCHEDULE/MAJOR BASELINE CHANGE) continued: SMET

Cause: 200 Atea surveillante and maintenance activities for REDOX repairs and U-

Plant roof repalr were intiated in FYoO with most of the' work planned for Frol.

Resolution: None; planned carryover.

PBS-EROY - Long-Term Surveillance and Maintenance (BCWS \$46K for FYOO)

Schedule Variance $=N / A$

- Cost:

\begin{tabular}{|c|c|c|c|c|}
\hline \multirow{2}{*}{ Surveillance/Maintenance $\&$ Transition Project } & BCWP & ACWP & Variance & \\
\hline & $\$ K$ & $\$ \mathbf{K}$ & $\$ \mathbf{K}$ & \\
\hline ERO5 Surveillance \& Maintenance & 13,338 & 13,093 & 245 & \\
\hline EROT Long-Term Surveillance \& Maintenance & 46 & 39 & 7 & Green \\
\hline TOTAL SM\&T & 13,384 & 13,132 & 252 & \\
\hline
\end{tabular}

PBS-ERO5 - Surveillance and Maintenance

Cost Variance $=+\$ 245 K ;+1.8 \%$ li.ast Month: $+\$ 374 k ;+3.1 \%$ ]

Cause: Herbicide application and KE/KW acid tank stabilization less than planned.

Resolution: Underrun was utilized for other ER work.

Cause: Underruns on B Plant S\&M due to delays in completing the filter changeout and duct work repalr on stack.

Resolution: Costs will be incieasing as B Plant stack was turned over to ERC in August.

Cause: KE/KW legacy waste? removal cost overrun; estinlate did not account for difficulties encountered.

Resolution: Overrun reffected in estimate at completion (EAC).

PBS-EROT - Long-Term SUrveillance and Maintenance (BCWS \$46K for FYOO)

Cost Variance :- N/A

\section{REGULATORY ISSUES: SM\&T}

A number of significant issues we't 'tientified and resolved turng froo. Those remainm at fiscal year end include?

PUREX and B Plant Canvon Roof Repairs: Funding for PUREX and B Plant canyon roof repals has not been ictentified for tit?

Status: The solice and thming of the funding has not been resolved. On July 6, BHI transmitted a letter to $R L$ rew.unmending PLREX anyon roof repall funding be frovided no later than the bugnning of FYol per the Memorandum of Agreement.

EXTERNAL ISSUES (i.e. HAB, Congress, etc.): SMKST

Nonte wentificed at this timne.? 


\section{ENVIRONMENTAL MANAGEMENT PERFORMANCE REPORT ENVIRONMENTAL RESTORATION \\ NOVEMBER 2000}

DOE-RL \& HQ ISSUES/REQUESTS (not covered elsewhere): SMET

None identified at this time.

INTEGRATION ACTIVITIES: SM\&T

None identified at this time. 


\section{Pacific Northwest National Laboratory Environmental Management Performance Report}

November 2000

PREPARED FOR THE U.S. DEPARTMENT OF ENERGY, RICHI ANI) OPERATIONS OFFICE OFFICE OF ENVIRONMENTAL MANAGEMENT

Pacific Northwest National I aboratory

Operated for the U.S. Department of Fnergy

by Battelle Memorial Institute 
PNNL Environmental Management Performance Report-November 2000

\section{Table of Contents}

INTRODIICTION

HXECITIVE SUMMARY

2

SAFETY OVERVIEW

2

SUMMARY OF FISCAI, YEAR 2000 PI:RFORMANCE $\ldots \ldots \ldots \ldots \ldots \ldots \ldots \ldots \ldots 2$

SUMMARY OF FISCAL, YEAR 2000 VPP AC"TIVITHS. $\ldots \ldots \ldots \ldots \ldots \ldots \ldots \ldots \ldots$

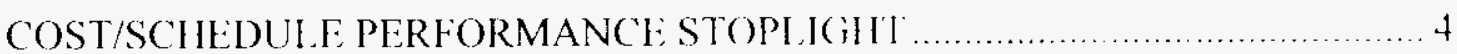

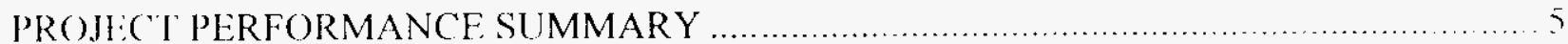

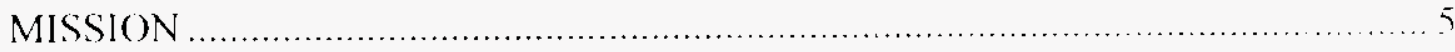

PIERORMANCE DATA AND ANAL YSIS .............................................

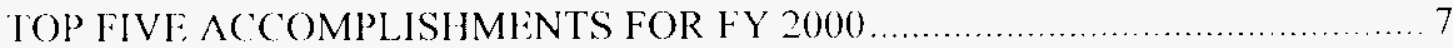

AIDI'TIONAL FISCAI, YEAR 2000 ACCOMPI ISHMENTS ......................... 8 
$T$ his document provides the Department of Energy Richland ()perations (office (I)()I:-RI.) with a report of the Pacific Northwest National I aboratory (PNNI.) performance by Battelle Memorial lnstitute and its subcontractors.

In Section $\Lambda$, the Executive Summary, text and graphics report the safety metrics status for all PNNL activities. Senior management's overall performance assessment of all Environmental Management activities conducted at PNNL is presented in a stoplight chart.

Section B. Project Performance Summary, provides a brief summary of the month serformance for the PNNI, lead activity, PNNI, Waste Management (PIBS RL,-ST01). More detailed information can be found within PNNI-7911-108a, PNNI, s Project Status Report for September 2000). Summary analyses pertaining to PNNI ‘s support to other Project Baseline Summaries (PBSS) are addressed in the contractor's report having lead responsibility for that scope.

Inless otherwise noted, information in this report is current as of September 30, 2000. 
$\mathrm{T}$ his section provides an executive-level summary of performance information and is intended to bring to management's attention that information considered to be most noteworthy. The section begins with overview of safety, a summary of $\mathrm{F} Y 2000$ performance, a summary of Fiscal Year (FY) 2000 Voluntary Protection Program (VPP) activities. followed by a stoplight chart on overall performance.

\section{Safety Overview}

$\mathrm{T}$ The focus of this section is on documenting trends in work-related injury and illness rates. The rates are presented graphically in this section and are tracked for significant changes. Current efforts to improve performance are being made through the continued implementation of the Integrated Environment, Safety and Health Maintenance System (ISMS), and the development and implementation of the Voluntary Protection Program (VPP).

\section{Summary of Fiscal Year 2000 Performance}

$\mathrm{T}$ he three FY 2000 performance indicators for injury and illness statistics were met this year with rates below the goals (lab upper limits) for Total Recordable Case Incidence Rate. Lost Workday Case Incidence Rate, and Lost Workday Incidence Rate (Severity Rate). The specific year end rates and goals (Lab Upper Limit) are noted in the text blocks associated with each of the following graphs:

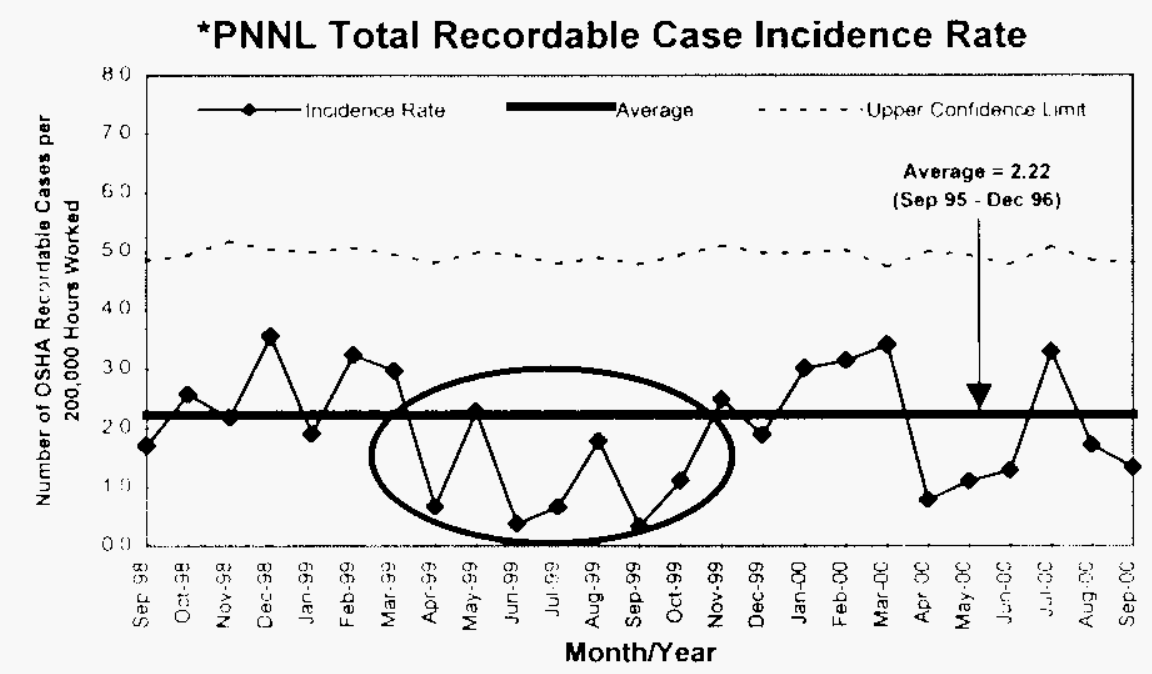

Flomkate (Wervien:

(cumulative Jo Date 2 ?

1.ab lipper l init ? i

I his indicaltur has been gencrally stable aner the lome term There was a dectealse in the rates duing the peried of April go - (botober (\%) firllawed by a ream back to an expected randomly fluctuating pattion whth the anlicipated control limits:

\footnotetext{
* Includes all Pacific Nerthuest Natuonal Latoralory Operations.
} 
PNNL Environmental Management Performance Report - November 2000

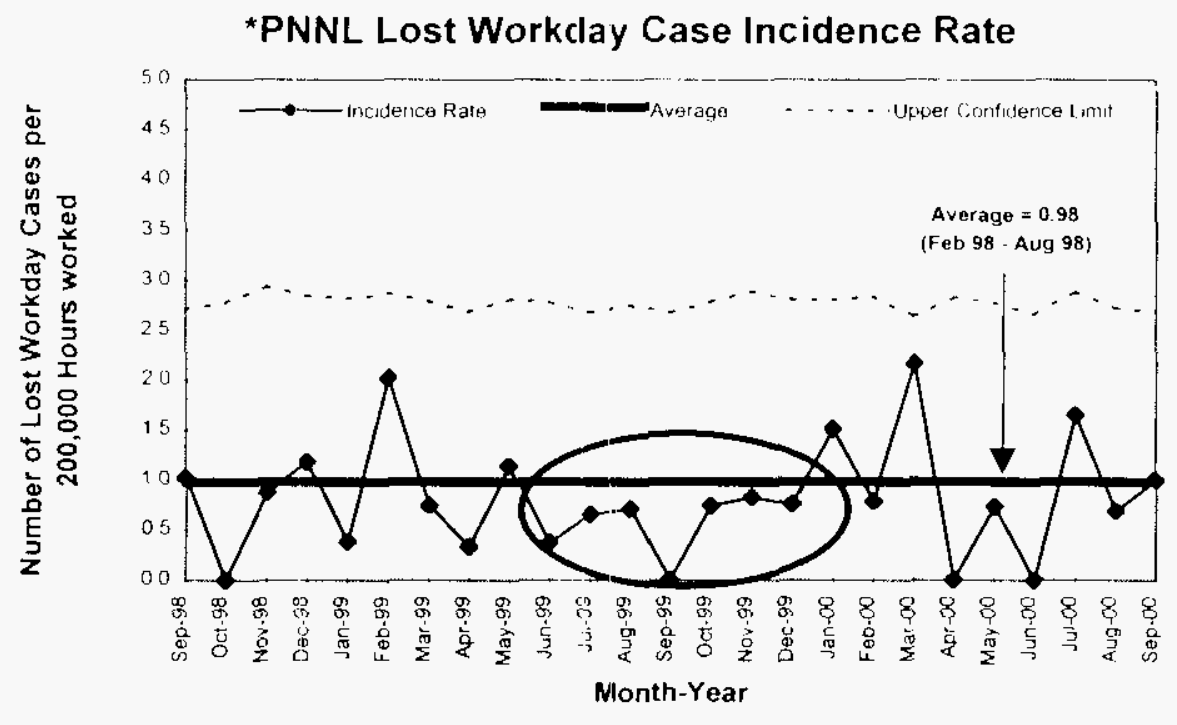

Fi ookate (Oversien:

(umulative Tulate 9

lab lipper l imil 12

This indicator hals heen generally stathe over the long term. There was a temporars

shert-term decrease durng the period of June 99 - Eecember (9) lollowed by a return back lo an expected randomly lluctuating pattern within the anticipated control limits.

*PNNL L.ost Workday Incidence Rate (Severity Rate)

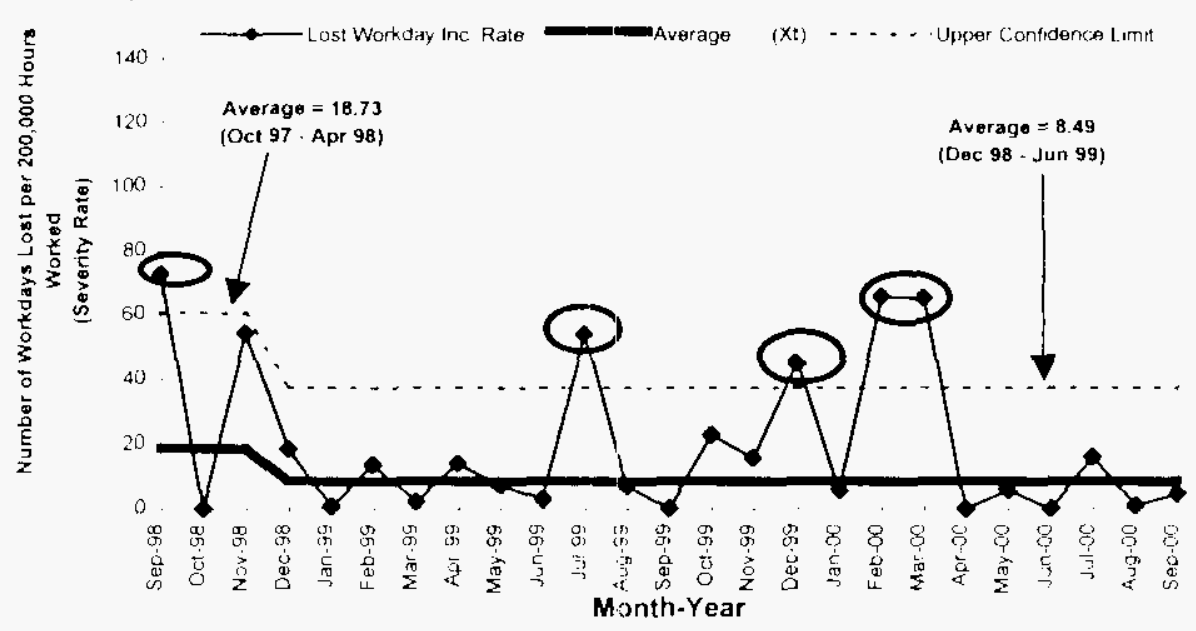

F Ookate Overvien: Cumulative fo bate 207 1.ah 1/pper I.imil · 300

The datia for the last six mombs have been randemly cycling within the normal anticipaled control limits. Past menths that are above the apper control limit with catses currenty accumulating lost workdiass are Jebruary 00 and March $(06$.

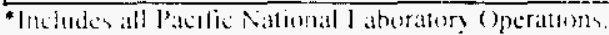




\section{Summary of Fiscal Year 2000 VPP Activities}

\section{Employee Participation}

Nine PNNI, staff members represented PNNL, at the VPP Region X conference in Maly in Seattle

Ten PNNI, staff members represented PNNI, at the VPP national conference in Algust in Seattle

\section{Staff Awareness Campaign}

The VPP Steering Committee distributed an informational hrochure that addressed live basic questions on VPP. Shortly after the brochure was sent out. staff received an electronic survey containing the five basic questions. Close to 2,000 staff members responded to the survey and received a safety award.

\section{VPP Application for STAR Status}

PNNI is the first organization to be submitting their VPP application via web site. IX)(E:

Richland Operations Office staff are currently reviewing this site, and DOF-Headquarters staff will review this site in November 2000 . Access issues are currently being worked so that the external reviewers can aceess the site.

\section{Cost/Schedule Performance Stoplight}

The following rating reflects overall cost and schedule performance for activities conducted by PNNL. (Narrative not required when rating is green.)

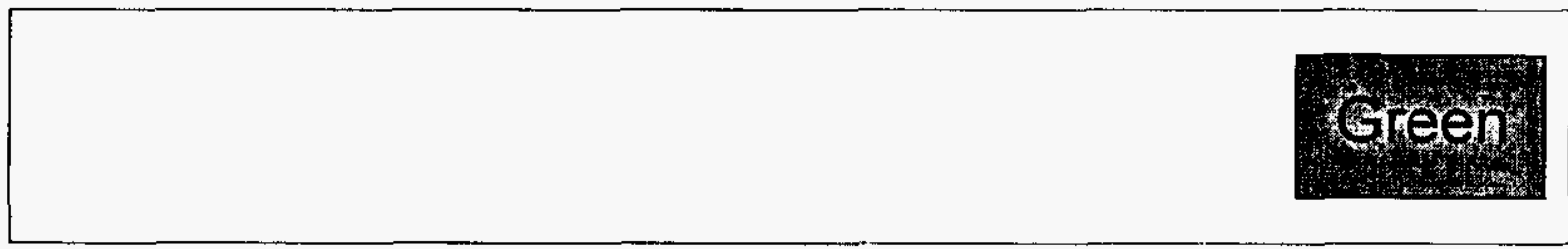

$\begin{array}{ll}\text { (ireen: } & \text { Satisfactory } \\ \text { Yellow: } & \text { Significant improvement required } \\ \text { Red: } & \text { Unsatisfactory }\end{array}$


$\mathrm{T}$ his section provides cost and ichedule performance. any signilicant issues. upcoming haseline change requests for the period covered. and Fiscal Year ( $\left.\mathrm{F}^{\mathrm{Y}} \mathrm{Y}\right) 2000$ aecomplishments. In IYY 2000, Battelle Memorial Institute has lead responsibility over PBSS RI, STO1. PNNI. Waste Management WBS 1.7.1.

\section{Mission}

WBS 1.7.1 provides PNNL with waste management services and compliant operations in support of science and technology development for the multiprogram needs of the U.S. I epartment of Energy (DOE) Complex. These services include:

- essential surveillance and maintenance of DOI laboratory facilities assigned to PNNI for safe containment of radioactive and hazardous materials

- infrastructure required to manise wastes and effluents currently generated at the PNNI,

- operational compliance services to meet regulatory requirements and operating permits including environment, safety and health regulations

- management of legacy wastes and contamination remaining from past PNNI, research operations.

\section{Performance Data and Analysis}

As of September 30,2000 the cumblative costs are $\$ 13.9$ million with a positive cost variance of $\$ 0.7 \mathrm{M}$ and a cumulative schedule variance of negative $\$ 0.2 \mathrm{M}$. Though cost and schedule variances are within $10 \%$ reporting threshold, a brief explanation of the primary activities that were not completed this fiscal year are described following the tables and chart.

\begin{tabular}{|c|c|c|c|}
\hline \multicolumn{4}{|c|}{ Cost Performance $(\$ M)$ : } \\
\hline & $\mathbf{B C W P}$ & $A C W P$ & Variance \\
\hline PNNL Waste Management & $\$ 14.6$ & $\$ 13.9$ & $\$ 0.7$ \\
\hline \multicolumn{4}{|c|}{ Schedule Performance $(\$ M)$ : } \\
\hline & $\mathrm{BCWP}$ & BCWS & Variance \\
\hline PNNL Waste Management & $\$ 14.6$ & $\$ 14.9$ & $(\$ 0.2)$ \\
\hline
\end{tabular}

\section{FY 2000 Cost/Schedule Performance - All Fund Types Cumulative to Date Status - $(\$ 000)$}

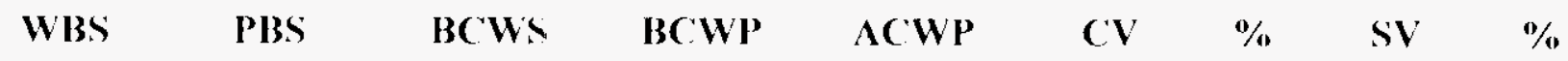

\begin{tabular}{|c|c|c|c|c|c|c|c|}
\hline 1.7 .1 & RL -STOOI & $\$ 14,870$ & $\$ 14.628$ & $\$ 13.888^{*}$ & $\$ 739$ & 5 & $\$(242)$ \\
\hline & Total & $\$ 14,870$ & $\$ 14.628$ & $\$ 13.888^{*}$ & $\$ 739$ & 5 & $\$(242)$ \\
\hline
\end{tabular}




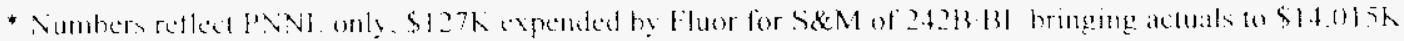

\section{Cost / Schedule Performance Indices}

FY $20(0)$ Cum tu Datc Siatus

(5ikn)is

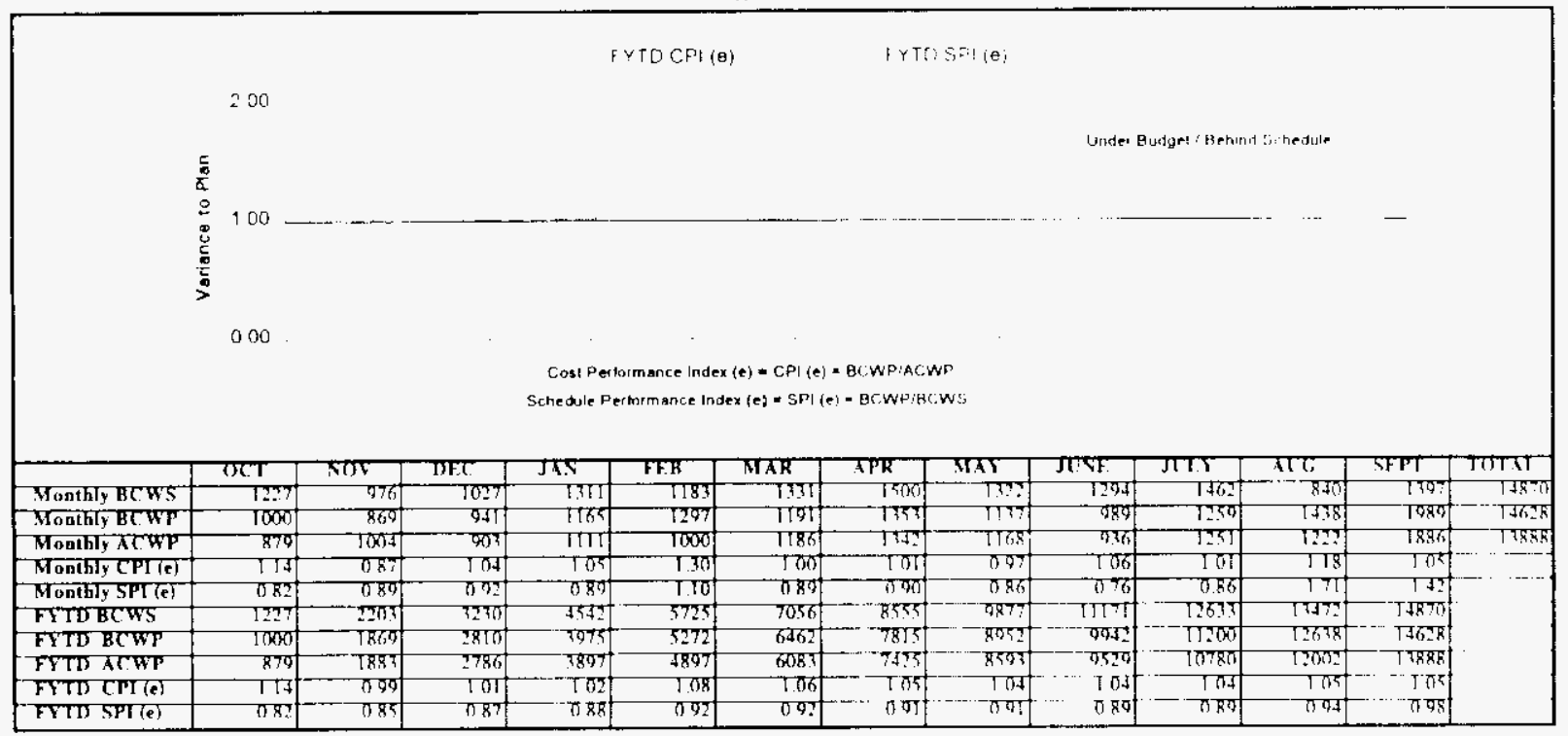

The positive cost variance of $\$ 0.7 \mathrm{M}$ results from reduced overhead rates and efficiencies A change request was approved on October 2 to replace/upgrade the heating, ventilation, and air conditioning (HVAC) system within Radiochemical Processing Laboratory (RPL) using programmatic underruns. A baseline change request is in process to redirect the remaining program underrun to replacement of RPL's electrical switchgear. The reliability of the switchgear is crucial for maintaining the facility safety envelop in the RPL according to the SAR.

The cumulative schedule variance is within reporting thresholds. The primary activities making up the year-end negative schedule variance are as follows:

- IDificulties were encountered completing the final details in the High Dose Solid Waste container design as well as a late start in fabrication of the drums. As a result of this delay the drum shipping dates for the 73 cans of transuranic (TRU)/low-level waste (I.I.W) is expected to occur in early FY 2001. Concerted efforts are being made to streamline the fabrication process and set priorities for which type of drums need to be available first.

- Four events delayed the cleanout of the RPL, 604 glovebox 1 ) shutdown of the area because of the range fire, 2) unplanned shutdown of the LAI, 3) three glowe change outs. and 4) high-efficiency particulate air (HEPA) filter replacement. All but one of the liquid samples from the eight columns with liquids in them was found to have a very high activity count, which made analysis more difficult. In order to handle the samples in the fume hoods, extensive dilution or chemical separation of the silver was required on all but one of the samples. The dilution required would make it impossible to meet the required detection levels. On September 7.2000 a routine Dioctyl-sebacate (I)OS) test of the 
HIPA filter on the exhaust line from the glovebox failed. indicating a bole or leakage past the filter. I nder these cor ditions, no work is allowed in the glovebox until the filter is replaced. Normally a routine activity, a new radiation work permit (RWP) had to be generated and a new bioassily requirement had to be satisfied. I iquids and the resins will be removed from the columes and tanks and put in plastic containers. ready for bag-out. These plastic containers are not suitable for long-term storage in a radioactive environment. Therefore. lunding must be continued into next $\mathrm{FY}$ so that these materials will not be left in an unsatis condition.

- Remaining work with the $6052 \mathrm{H}$ Radiological Contamination facility includes disposal of fluorescent lights from the growth chamber; removal of construction support equipment; completion of the final release survey; and excess of salvaged equipment. 'The waste is currently at a subcontractor for size reduction.

- The integrity assessment of the radioactive liquid waste tank (RI.WT)-piping is currently on hold with no defined completion date. The integrity assessment was delayed because the 204-AR Facility (receiver facility) is not ready, and Pacific Northwest did not want to add any liquids to the tank to make it a radiologically controlled tank until the receiver facility is ready. The earliest the 204-AR Facility will receive waste via the L.R-56 Truck is FY 2001.

Four FY 2000 change requests were approved either deferring or adding scope to fiY 2001 baseline using FY 2000 funds.

- PWM2000-009, "High Dose Waste and 604 Glovebox Schedule Revisions, RI, Milestone Delays," deferred $\$ 139 \mathrm{~K}$ of legacy waste disposal scope into FY 2000. (Approved $8 / 28 / 00)$

- PWM2000-013, “Adjust Project Baseline to Reflect Basis of Estimate Revision and Deferral of Activities into FY 2001," deferred $\$ 165.3 \mathrm{~K}$ of scope associated with liquid waste disposal using radioctive liquid waste system (RI,WS). (Approved 10/2/00)

- PWM200(0-014. "Scope Deferral from FY 2000 to FY 2001." deferred $\$ 34.2 \mathrm{~K}$ of scope to conduct air emissions inventiory and air compliance inspections for six Research and Development (R\&D) laboratories into FY 2001. (Approved 10/2/00)

- PWM2000-016. "HVAC' ('ontroller Replacement/Upgrade," added $\$ 335 \mathrm{~K}$ of scope in IY $\mathrm{Y}$ 2001. (Approved 10/2/00)

\section{Top Five Accomplishments for FY 2000}

The following reflect the top five (5) accomplishments of the Waste Management \& Operational Compliance Program in FY 2000.

(Categories are as follows:

Momentum How in terms of waste processing rates. etc. the cleanup of thantord has been "sped up". 
progress What "thinge." have been achieved this year in terme of amount and percentages

comptetion \& Removal What's done and what's gone.)

Completed demolition of the $331 \mathrm{~A}$ Building under Comprehensive Invironmental Response. Compensation, and I iability Act CIRCLA process (C'ompletion and Removal).

Completed cleanout of 9.000 gallons of potentially radioactive material contained in the 3.31 Building Animal Waste Septic Tanks (Completion and Removal).

Completed implementation of the FY 1999 and FY 2000 updates to the RPI. Safety Analysis Report $(S \wedge R)$ in order to maintain the facility safety envelope (Progress).

Increased amount of waste processed through the Hazardous Waste Treatment Init (HWTl!) more than ten times previous years $(3.174 \mathrm{kgs}$ treated vs. $309 \mathrm{kgs}$ in last two FYs) (Momentum).

Twenty-six (26) metric tons (MT) of hazardous (HA\%), $64 \mathrm{~m}^{3}$ of l.I.W. $12 \mathrm{~m}^{3}$ of low-level mixed waste (I.LMW), and $1 \mathrm{~m}^{3}$ of TRI currently generated wastes shipped for storage or disposal (Progress).

\section{Additional FY 2000 Accomplishments}

\section{Progress -}

Significant progress was achieved in integrating environmental compliance activities throughout all environmental management services provided to the I aboratory.

A $\$ 19 \mathrm{~K}$ investment in three Pollution Prevention (P2) projects generated from a $5 \% \mathrm{P} 2$ fee will result in annual savings of $\$ 26,067$ to the I aboratory.

Successfully obtained required approvals from regulators to allow continued compliant laboratory operations

Completed 15,701 radiological surveys and 178 preventive maintenance checks and routines: collected and counted 6,206 air samples; conducted 702 nuclear material inspections: supervised 10,257 access entries into radiological control areas within the RPI.

Completed 77 individual routine surveillance \& maintenance (S\&M) inspections on 30 excess lacilities assigned to PNNI.

Submitted Multi-Year Work Plan (MYWP) deliverables on schedule and provided timely support for the proposed restructure of the Ilanford Work Breakdown Structure (WBS).

Completion -

Suggested improvements from the fY 1999 self-assessment survey were implemented 
Positive feedback was received from the FY 2000 Independent cost kstimate review of the program conducted by the Is Army Corps of Ingineers. 


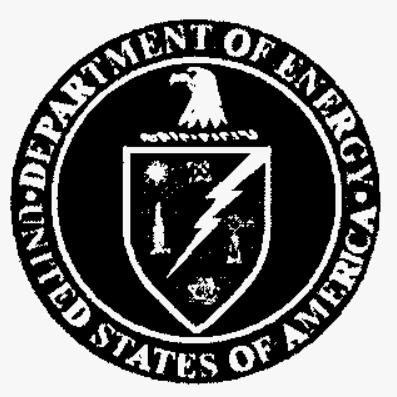

\section{Regulatory Unit}

\section{Monthly Performance Report}

September 2000

Office of Safety

Regulation of the

RPP-WTP

Contractor

\section{November 2000 \\ Environmental Management Performance Report Submittal}

Richland Operations Office

P.O. Box 550, A4-70

Richland, Washington 9352 


\section{Trable of Contents}

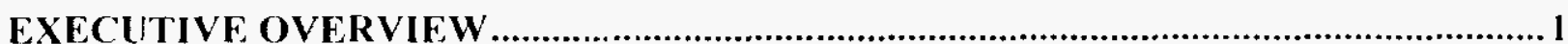

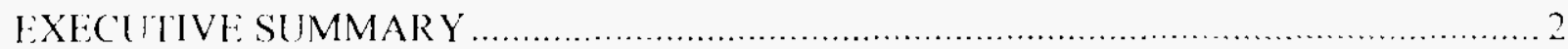

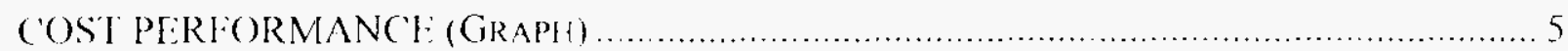

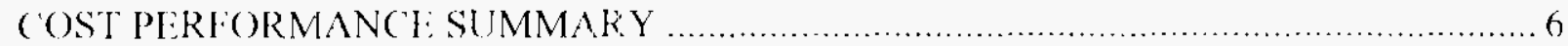

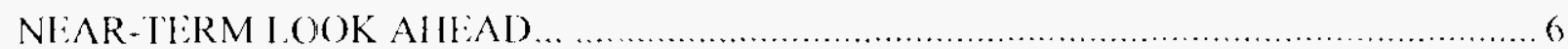

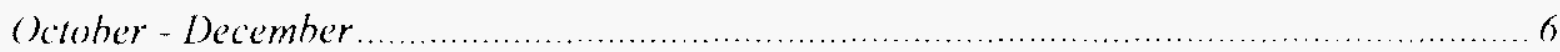

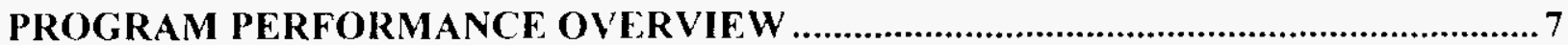

PERFORMANCF SUMMARY (CHART) - PROGRAM DIRECTION AND PROGRAM SIIPPORT....9

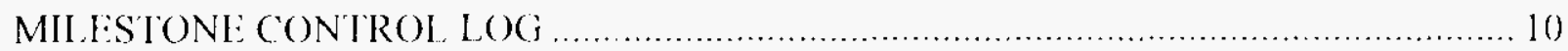

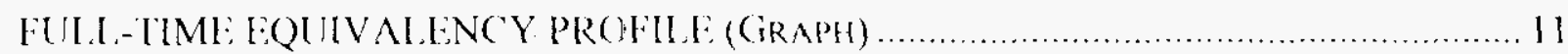

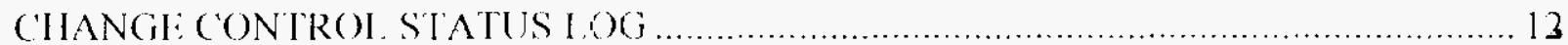




\section{EXECUTIVE OVERVIEW}




\section{EXECUTIVE SUMMARY}

On May 8, 2000. U.S. Secretary of Energy Bill Richardson announced that he would terminate the BNFI. Ine. privatization contract and seck bidders for a new contract to be awarded early in the next calendar year. (On August 31. 2000, the request for proposal (RFP) under a different contracting approach to continue the design, construction, and commissioning of the waste treatment plant project was issued. The new contract is expected to be in place by lanuary 15,2001. These events have resulted in a decision to transition the Regulatory Unit's (RI's) organization and workscope to the ()ffice of River Protection (ORP), and future monthly reporting will be to that office.

Highlights of fiscal year 2000 are captured below.

\section{INTEGRATED SAFETY MANAGEMENT (ISM) APPROACH}

The RI contirmed implementation of Safety Management six months ahead of the Department"s goal of September 30, 2000. Standard 4 of the Contract"s Statement of Work required BNFL to "develop and implement an integrated standards-based safety management program." The contract approach to safety required compliance with applicable laws, regulations, and requirements; conformance to DOF:stipulated top-level safety standards and principles; and adherence to the I)( ) process for establishing safety standards and requirements. The process for establishing safety standards was based on the principles of ISM. The RU emphasized that a clear, central concept of ISM was that contractors should tailor the basic framework for ensuring protection of the public, workers and the environment to the specifics of their work. This concept emphasized the need to fit the safety measures to the specific hazards of the work. The Contract provided for initial and subsequent approvals of changes to the (ontractor"s Integrated Safety Management Plan (ISMP) and ongoing assessment of the Contractor's ISMP implementation. These provisions, executed under the authority and means established by the Regulatory official, demonstrated that ISM had been implemented for the contract.

\section{INIDUSTRIAI, HYGIENE AND SAFETY (IH\&S)}

The RI I developed an IH\&S Regulatery Plan. The original belief was that the Oecupational Safety and Health Administration (OSHA) would regulate the IH\&S of the RPP-WTP' Contractor. (OSHA declined, and in order to ensure that an adequate IH $I \& S$ regulatory program was defined and in place before the start of construction. Dr. Carolyn Huntoon named the RU as the I)(OE element responsible for regulating occupational safety and health. The RI defined a comprehensive program for regulating IH $\mathrm{ES}$, and issued the Regulatory Plar in May 2000.

In April 2000, the RI received the BNFI, plan for protecting workers, subcontractors, and visitors from non-radiological hazards. The plan covered the period from the start of limited construction through cold startup. The RI completed an initial review and found the plan to be acceptable for a formal, detailed review. The RI completed its formal review of the BNFI. Non-radiological Worker Safety and Health Plan and provided comments to BNFI. Although the document was available to the public and the document was provided 10 the Confederated Tribes and Bands of the Yakama Nation at their reguest. no external comments were received. Due to contract termination. BN NII was unable to respond to the RII's comments; accordingly, the RI documented its review and issued an Assessment

$$
10-18-(30)
$$


Report. The RI found that the BNIF. Plan was acceptable subject to three conditons:

1. Addition of a clear statement of who has ultimate responsibility for safety

2. I Eefinition of the terms "stop work, "imminent danger." and "unsafie acts or conditions."

3. Commitment to completing and implementing the equipment and tool inspection program before start of construction.

As a result of the RII reporting changes, IH\&S regulatory responsibility will be transfirred to ORP' Office of Invironmental, Safety. Health, and Quality (FiSH\&()).

\section{REVIEW OF THE BNFL PAR'T B-1 FACILITY ANI PROC FSS DESIGN DELIVERABLES}

At the request of ORP, the RU completed its review of BNFI 's Part B-1 facility and process design deliverables. The RU review team consisted of RU staff. RI I contractors, and I S. Nuclear Regulatory Commission (NRC) staff from the Special Projects Branch.

The RU reviewers determined that the BNFI, facility and process design documents were not at a level of detail required to support the Hazard Analysis Report (IAR) or the Preliminary Safety Analysis Report (PSAR). In the absence of the required information regarding which standards BNFI, had invoked, it was not possible to determine if the design achieved adequate safety. Additional design information required to support the Construction Authorization Request ( $A R$ ) included further development of the design integrated with identification of items that have been determined to be important to safety.

\section{SELF-ASSESSMENT OF THE RU'S READINESS-TO-PROCEEID INTO PAR'T B-2 OF THE, RPP-WTP CONTRACT}

The RU performed a self-assessment to determine if management systems and processes were in place to accomplish assigned regulatory functions. The self-assessment examined ten areas of interest against specific review criteria. The team reviewed project documents and interviewed personnel from the RU and its support contractors, RL, ORP, DOE-Headquarters, the NRC. and BNFL.

In general, the team concluded that the RU management systems and processes are in place to accomplish the RU's responsibilities during Part B-2, and that the RU is effectively managing the regulatory program. In particular, the RU accomplished its regulatory responsibilities as outlined in RI./RE(j-97-10, Regulatory Plan, which defines implementation objectives of I)( ) I:/RI - $96-25$. 'olicy for Safety Regulation of the RPP' Waste Treatment Plant (ontractor, and DOOE:RI.-96-26. Memorandum of Agreement for Safety' Regulation of the RI'P Waste' Treatme'nt contractor.

\section{TOPIC AI, MEETINGS, INSPECTIONS \& DESIGN REVIEWS}

The RU conducted 8 Topical Meetings, observed 47 Design Reviews, and completed 7 Inspections of BNFI, during FY 2000. The topical meetings provided a mechanism for addressing issues which the Initial Safety Analysis Report review identified as not adequately resolved. The Design Reviews contributed to the RU's mission by providing detailed information concerning structures, systems and components that are important to safety and that are part of the facility design. The Inspections provided oversight in accordance with the contract with BNII, Inc. 
Regulatory L But Monthly Performance Report

This page intentionally left blank. 


\section{Regulatory Unit Cost Performance}

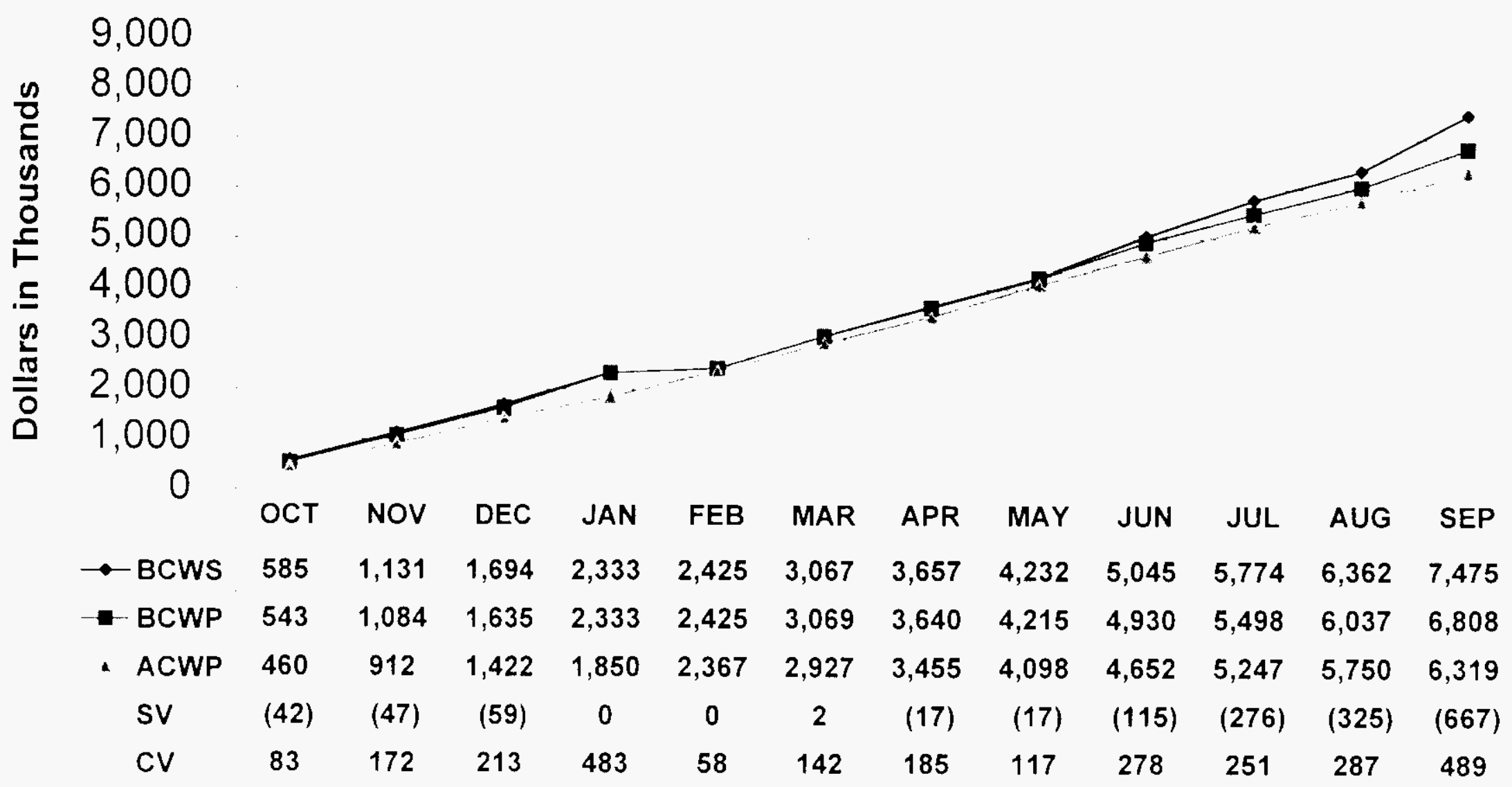




\section{COST PERFORMANCE SUMMARY}

The FY 2000 fiscal year end performance reflected an unfavorable schedule variance of $\$ 667 \mathrm{~K}$ and a favorable cost variance of $\$ 489 \mathrm{~K}$. The unfavorable schedule variance is due to various delays in receipt of deliverables for RU review (SAP, I CAR, CAR) as a result of the BNFI. contract termination. The favorable cest variance is a result of lower than anticipated costs associated with developing Inspection procedures, observing I esign Reviews and resolving Topical lssues.

\section{NEAR-TERM LOOK AHEAD}

The termination of the BNFL, contract and the impending transition of the RU to ()RP have impacted a majority of FY 2000 and $\mathrm{FY} 2001$ RU work activities. Planned first quarter activities include:

\section{October - December}

- Review CHC Radiological Protection Program for Construction

- $\quad$ Iivaluate CHG capability to safely change the authorization basis

- Participate in K-Basin Operational Readiness Reviews 


\section{PROGRAM PERFORMANCE OVERVIEW}


This page intentionally left blank. 


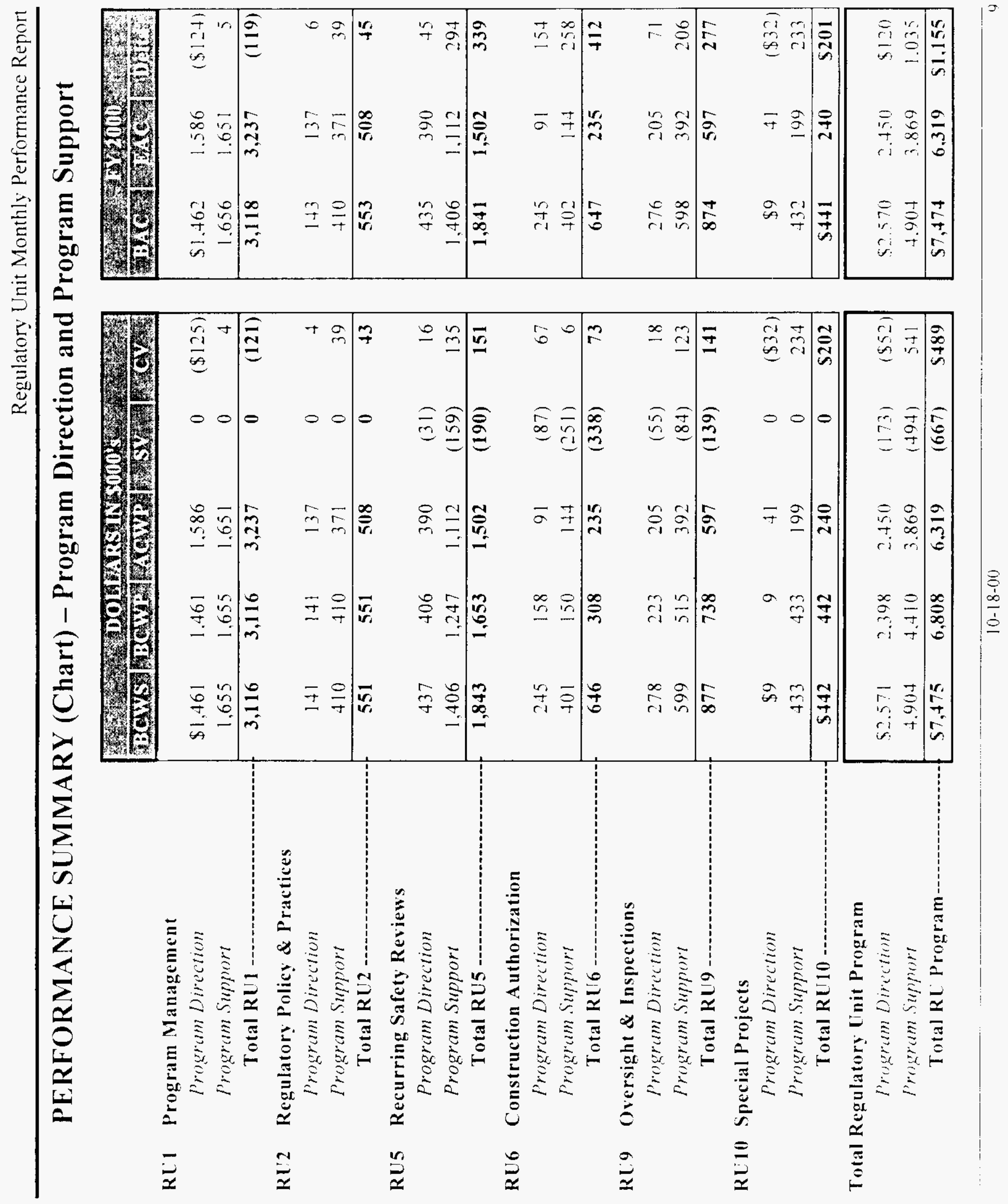




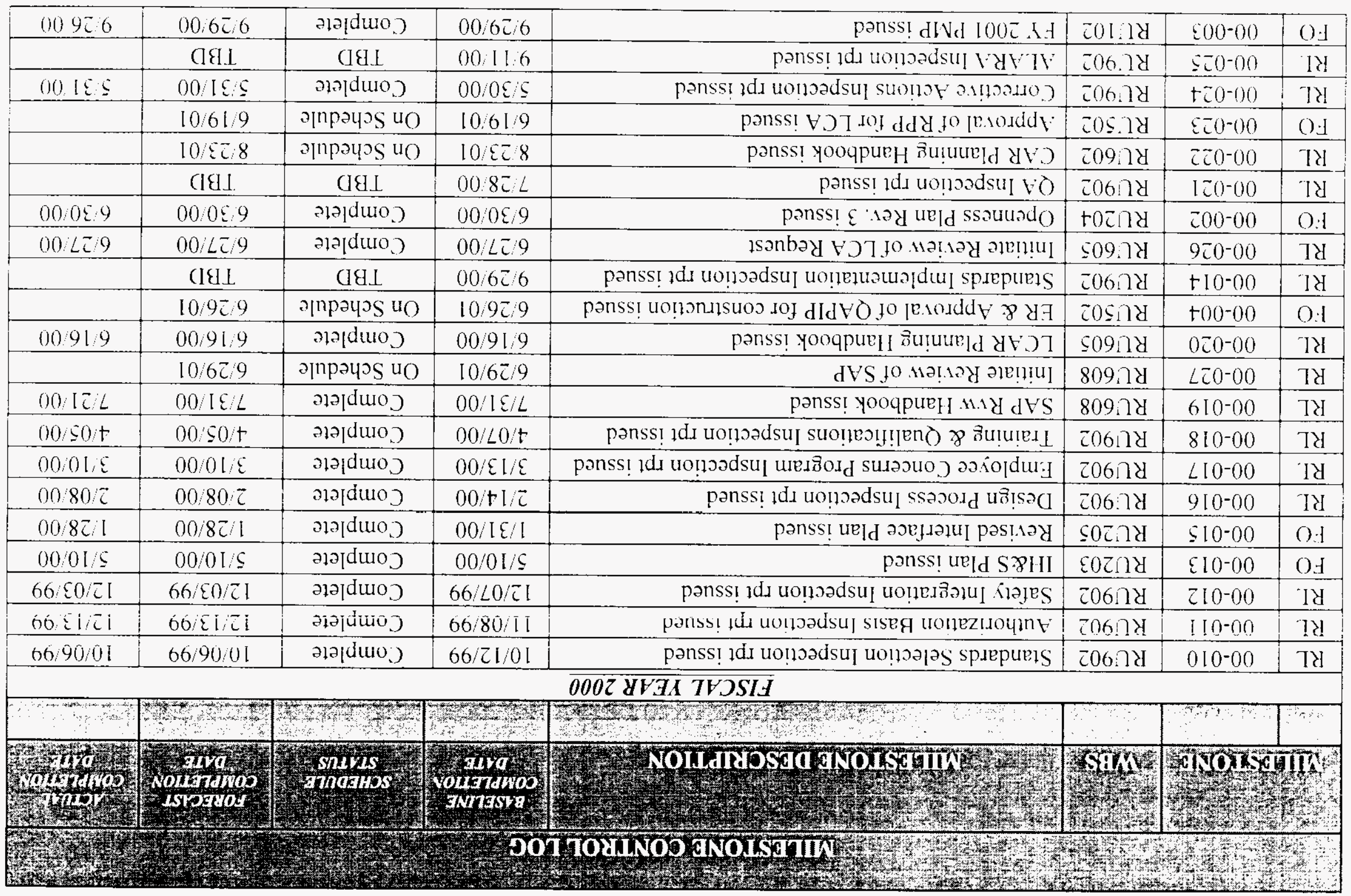

DOT TOYLNOJ JNOLSA'TIW 

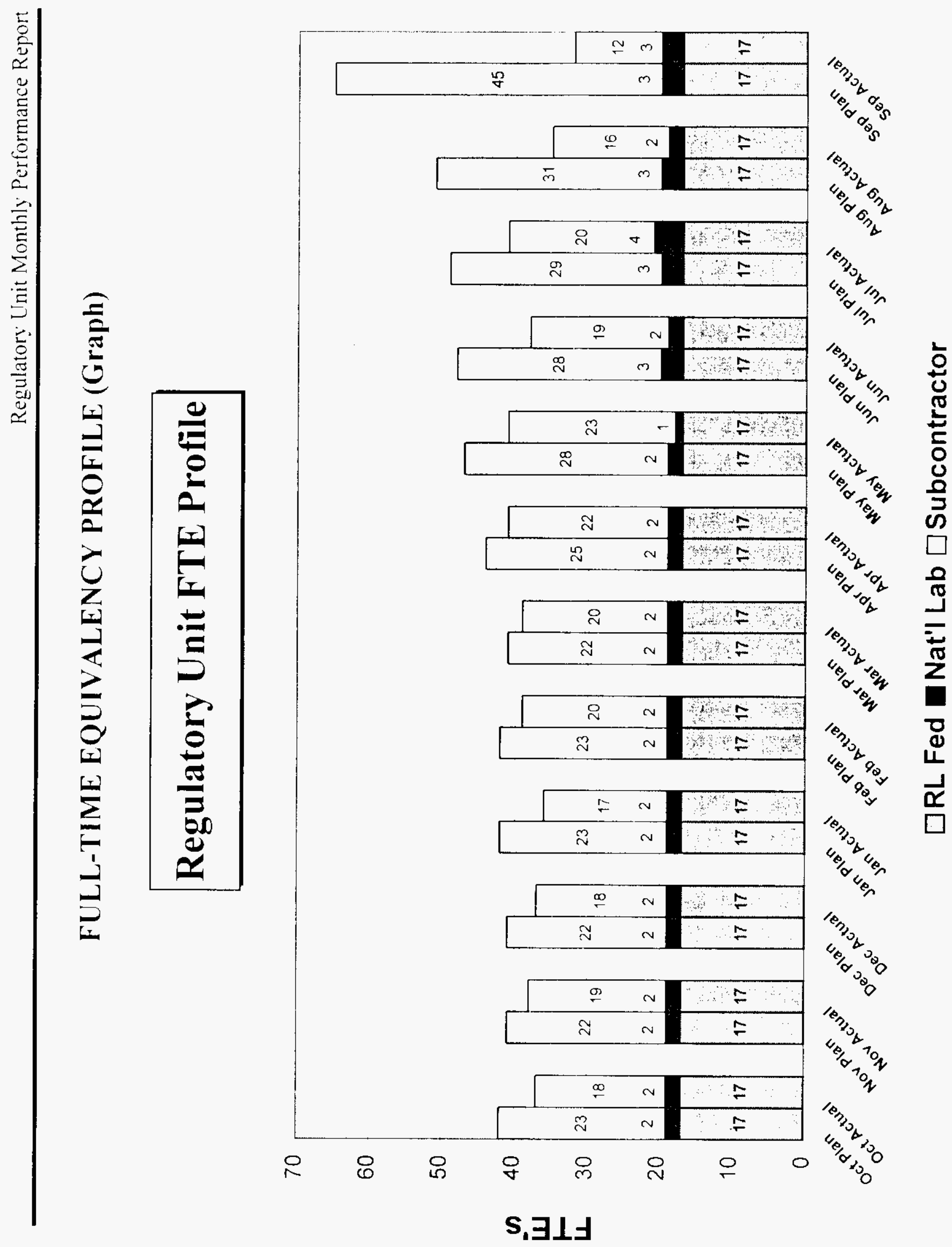


\section{CHANGE CONTROL STATUS LOG}

\begin{tabular}{|c|c|c|c|c|c|c|c|}
\hline ats & 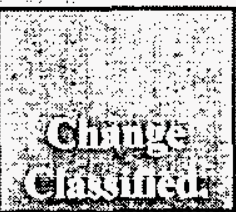 & 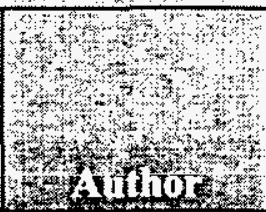 & $\frac{1}{4+2}$ & 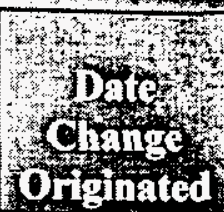 & 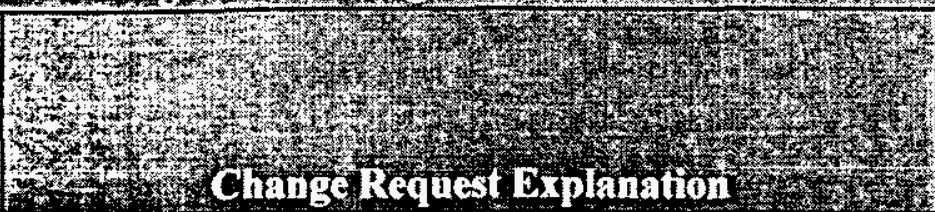 & andig & 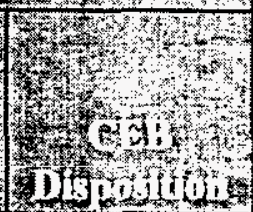 \\
\hline $00-001$ & I & K.D. Grindstaff & 1.10 & $11 / 99$ & $\begin{array}{l}\text { Processing of the FY } 1999 \text { Carryover into FY } 2000 \text { Baseline } \\
\text { and Realignment of FY } 2000 \text { Cost Savings to Emergent Priority } \\
\text { Workscope. }\end{array}$ & $11 / 2499$ & Approved \\
\hline $00-002$ & II & K.D. Grindstaff & 1.10 & $12 / 99$ & $\begin{array}{l}\text { Added new emergent workscope associated with impact risk } \\
\text { balancing between TWRS and the TWRS-P facility. }\end{array}$ & $12 / 03: 99$ & Approved \\
\hline $00-003$ & II! & K.D. (irindstaff & 110 & 100 & $\begin{array}{l}\text { Redistributed funds associated with a task package titled Othar } \\
\text { Direct Cost }(04240 D C) \text {. }\end{array}$ & 11800 & Approvid \\
\hline $00-004$ & II & K.D. Grindstaff & 1.10 & 100 & $\begin{array}{l}\text { Renamed Cost Account RU1002 from K Basin SAR to Misc. } \\
\text { RU Reg. Activities and separated the CAP into three tasks; K } \\
\text { Basin SAR, RL Quality Assurance Program Plan, and WIPP } \\
\text { Reg. Program Development. }\end{array}$ & 12000 & Approved \\
\hline $00-005$ & I & K.D. Grindstaft & 1.10 & 200 & $\begin{array}{l}\text { Implemented the most recent resource activity planning effort. } \\
\text { utilizing the Project's FYTD cost savings. Mid-year } \\
\text { rebaselining effort. }\end{array}$ & 22500 & Approved \\
\hline $00-006$ & II & K.D. Grindstaff & 1.10 & 500 & $\begin{array}{l}\text { Initiated the detailed review of the BNFL process and facility } \\
\text { design. which will provide the RU a current understanding of } \\
\text { the BNFL process and facility design. }\end{array}$ & 50200 & Approsed \\
\hline $00-007$ & I & K.D. Grindstaff & 1.10 & 500 & $\begin{array}{l}\text { Aligned the RU to the latest BNFI, schedule delay prior to the } \\
\text { decision to terminate the BNFL Hanford Contract. }\end{array}$ & 53000 & Approsed \\
\hline $00-008$ & II & K.D. Grindstaff & 1.10 & 600 & $\begin{array}{l}\text { Implemented workscope to support decisions related to the } \\
\text { relative risk of TWRS compared to the TWRS-P facility. }\end{array}$ & 62200 & Approved \\
\hline $00-009$ & II & K.D. Grindstaft & 1.10 & $7: 00$ & $\begin{array}{l}\text { This change request documented } \$ 750 \mathrm{~K} \text { of Programmatic } \\
\text { efficiencies that are being made available for other Hanford Site } \\
\text { priority workscope. This is a funds only change request. }\end{array}$ & 80200 & Approved \\
\hline $00-010$ & 1 & K.I. Grindstaff & 1.10 & 900 & $\begin{array}{l}\text { This } \mathrm{BCR} \text { bridges the } \mathrm{RL}^{\prime} \mathrm{s} \text { detailed CAP planning from } \mathrm{FY}^{\prime} \\
2000 \text { to } \mathrm{FY} 2001 \text {. }\end{array}$ & 92600 & Approved \\
\hline
\end{tabular}




\section{GLOSSARY}

Actual cost of work performed (ACWP): The actual cost incurred and applied or distributed for the work performed within a given time period. It includes all labor categories. material. any other direct costs, subcontract work, and function overhead.

Approved baseline: The budget authorized to perform the workscope that has been agreed upon by the customer and the contractor(s). It is portrayed in the Multi-Year Work Plan with all approved changes. This baseline may or may not be fully funded, and could be more or less than the compliance baseline.

Budget at completion (BAC): The sum of budgets established to complete a program and/or project or any component of a program and/or project.

Budgeted cost of work performed (BCWP): The value for completed work measured in terms of the planned budget for that work. It is synonymous with carned value.

Budgeted cost of work scheduled (BCWS): The time-phased budgeted value of work scheduled to be accomplished over a given time period. The BC WS for a total cost account through its entire period of performance is equal to the BAC for the cost account.

Carryover Workscope: The estimated dollar amount of the workscope that was not completed during the fiscal year and which will be carried over and completed in the next fiscal year.

Compliance baseline: The budget that is required to perform the workscope necessary to be in compliance with State and Federal regulations, enforceable agreement milestones. and I).NFSB milestones. The level of activity required to be in compliance assumes sufficient funding. Note: Because approved baselines are considered to be compliant, this column will likely be eliminated.

Contract Inherited: The assumed budget for the planned scope of work at the time a new contract is signed by the company responsible for performing the work.

Cost variance (CV): The difference between $B C W P$ and $\triangle C W P(C V-B C$ ' $P P$ - $A C$ C $W P$ ). $A t$ any time, it shows whether the work actually performed has cost more or less than the amount budgeted for the same work.

Cost Performance Indicator (CPI): The CPI is the ratio of $13 C^{\prime} W P$ ' to $A C$ ' $W P$ ' or (BC WP/AC WP).

Earned value (EV): The periodic, consistent, and objective measurement of work performed in terms of the budget planned for that work. The EV is synonymous with the BC WP and it is compared to the BCWS to obtain schedule performance and to the ACWP to obtain cost performance. 


\section{GLOSSARY (CONTINUED)}

Estimate at completion (EAC): Cost allocated to the work breakdown structure element to date, plus the estimate of costs for authorized work remaining. Authorized work remaining includes any undistributed budget

Fiscal Year Spending Forecast (FYSF): The estimated total that will be spent from (october through September (current Fiscal Year).

lunding carryover and new Budget Authorization (BA): This funding represents both the funding allocated to perform workscope planned in the prior fiscal year, not completed. and approved to be performed in the current fiscal year. as well as new BA to perform the approved baseline workscope.

Funding target: The level of funding that is anticipated (as a result of the Integrated Priority List process) in a given Fiscal Ycar based on an assumed funding level for the Site.

Multi-Year Work Plan - 10/1/XX: The Project's approved cost'schedule/technical baseline at the beginning of the fiscal year.

Project Execution Module (PEM): The Project Execution Module (PEM) of the Integrated Planning, Accountability, and Budgeting System-Information System (IPABS-IS) replaces the Progress Tracking System (PTS) as EM Headquarters centralized system for reporting financial, milestone, performance, and other execution-year information for PBSs, sub-PBSs, T"TPs, and line item construction projects. In addition, this module collects mid-year and year-end actual performance intormation against the agreed upon management commitments for the current execution year.

Schedule Performance Indicator (SPI): The SPI is the ratio of BCWP to BCWS, or (BC WP/BCWS).

Schedule variance (SV): The difference between BCWP and BC WS (SV - BC WP - BC 'WS). At any time, or for a given period of time, it represents the difference between the planned dollar value of work actuilly accomplished and the value of the work scheduled to be accomplished.

Work breakdown structure (WBS): A product-oriented family tree division of real estate. hardware, software. services, and data products that organize, define. and display all of the work to be performed in accomplishing the program and/or project objectives. 